


\section{UNIVER SITY \\ OF FLORIDA \\ L I B R A R I E S}

In Memory of

Edwin C. Kirkland 



\section{MEMOIRS OF THE \\ AMERICAN FOLKLORE SOCIETY}

VOLUME 41

1947 



\title{
An Analysis of Coeur D'Alene Indian Myths
}

\author{
By \\ GLADYS A. REICHARD \\ with a comparison by \\ Adele Froelich
}

PHILADELPHIA

AMERICAN FOLKLORE SOCIETY 
COPYRIGHT 1947 BY

THE AMERICAN FOLKLORE SOCIETY

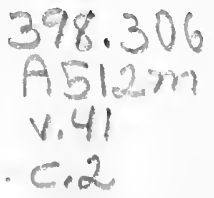

(All rights reserved)

Printed in the United States of America ARCHIVES PUBLISHING COMPANY OF PENNSYLVANIA, INC. HARRISBURG, PENNSYLVANIA 
To

Julia and Lawrence 
Digitized by the Internet Archive in 2011 with funding from LYRASIS Members and Sloan Foundation 


\section{PREFACE}

The work presented in the following pages is an indirect result of a linguistic study financed by the Committee on American Indian Languages of the American Council of Learned Societies. A grant for preparation of the manuscript was made by the Council for Research in the Humanities, Columbia University. Grateful acknowledgment is made to these institutions for making the work possible.

The name of the Indian tribe under discussion is of French derivation meaning Heart of Awl or Awl-hearted and the first $e$ of Alene would properly be written with a circumflex. However since a lake and a town in Idaho have the same name written without the circumflex, the name of the tribe also conforms to local usage. The Coeur d'Alene language is phonetically complex, a large series of $k$-sounds and harsh glottal stops being especially characteristic. The writing of Coeur d'Alene words has been greatly simplified in this volume since such simplification does not detract from the points made.

Considerable effort has been put forth to make the translations intelligible, sometimes by adding an explanatory phrase not in the text, sometimes by transposing phrases and sentences and sometimes by the use of notes. The Coeur d'Alene sentences are not always clear if literally translated and besides, the informants often offered voluntary explanations. Titles (not given by the informants) have been selected to indicate as well as possible the point of the tale, in many cases the main theme is inserted as a catchword after the primary title and the outline of each myth or tale was made with the purpose of making the episodes easily found through catchword or theme or both. In the classification of the tales those were included in the Coyote cycle which he is featured in although he is not the protagonist in all of them.

All of the comparative work was done by Adele Froelich, the only changes in her work being changes in arrangement.

Barnard College, Columbia University

Gladys A. Reichard 


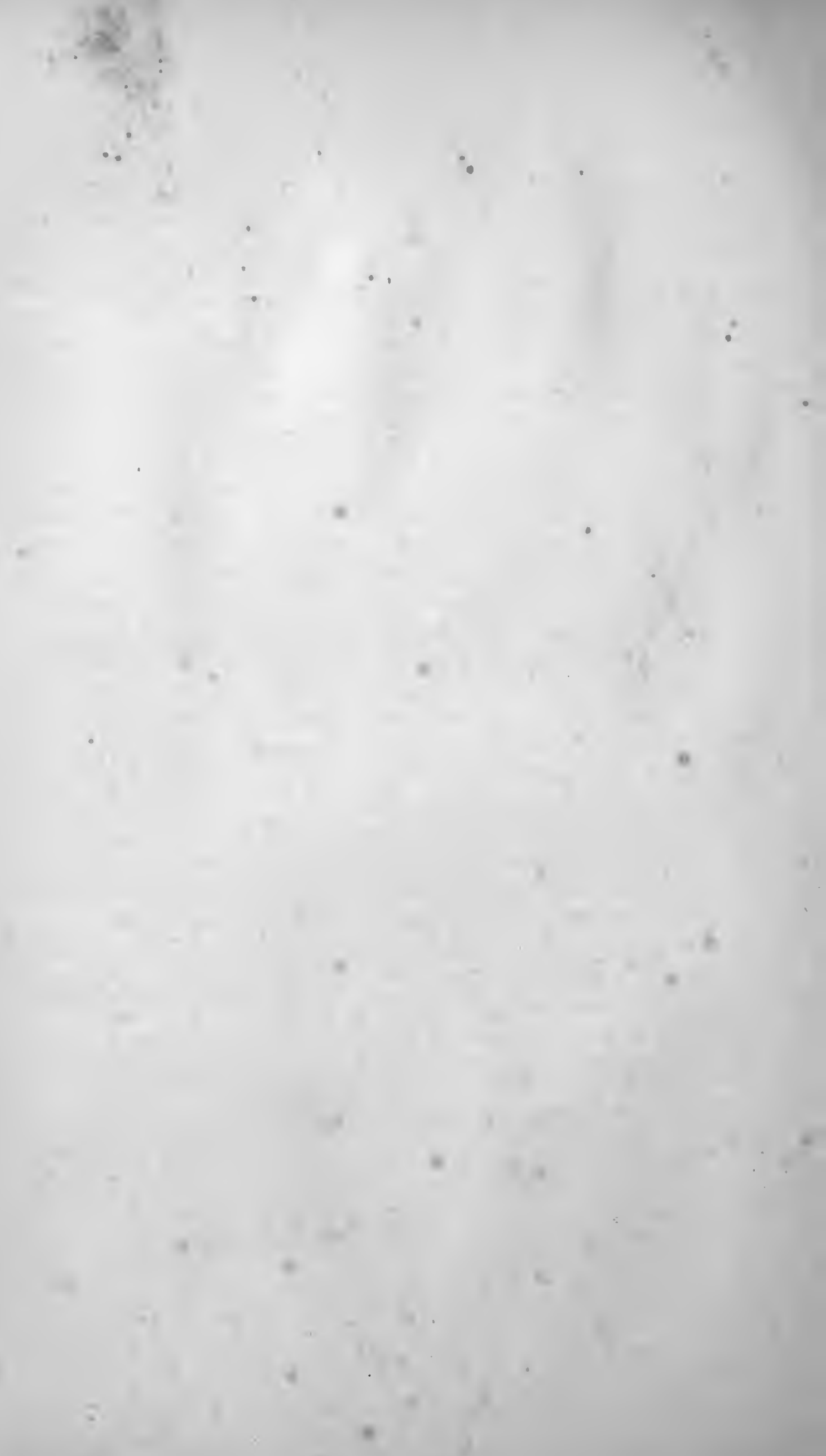




\section{CONTENTS}

PAGE

Preface

vii

CHAPTER

I. Introduction

II. The Style of Coeur d'Alene Mythology

III. Cultural Reflections in Coeur d'Alene Mythology

IV. Diffusion and Mythological Processes

V. The Myths and Tales

A. 1. Chief Child of the Root (Transformer) ____ 57

B. Coyote cycle

2. Origin of Indian tribes (From Parts of Monster) -..

3. Coyote overpowers Sun (Securing Sun Disk) _..

4. Coyote steals his daughter-in-law

5. Little Beaver

6. Coyote devours his own children

7. Coyote loses his eyes (Eye Juggling)

86

8. Coyote hunts with Crane and releases salmon

89

9. Story of Lynx

98

109

a. by Tom Miyal

b. by Dorothy Nicodemus

109

113

10. War between Land and Water People

11. Dog husband

12. Coyote and Fox gamble with the Fish

13. Coyote marries Squirrel, sister of Geese

128

14. Coyote imitates Magpie (Bungling Host)

15. Coyote and Badger

16. Calling the deer

134

17. Calling one's kind

a. by Dorothy Nicodemus

b. by Tom Miyal

18. Coyote kills Cricket with elk fat (Mistaken Kindness)

19. Coyote and Nighthawk change coats (Rolling Rock) 143

20. Cricket rides Coyote

21 . Coyote snares the wind 


\section{CONTENTS (Continued)}

CHAPTER

C. Myths not in Coyote cycle _.__ 148

22. Catbird 148

23. Skunk and Fisher -_____ 158

24. The girls who stole dentalia (Kidnapping) _____ 165

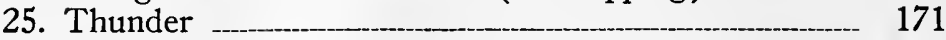

26. Waterbird contests for woman (Gift Test) _._.___- 174

27. Water Monster Woman _._____________________ 177

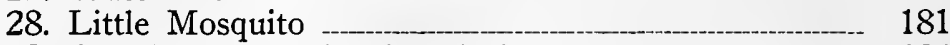

29. Grizzly and his brothers-in-law ____________ 184

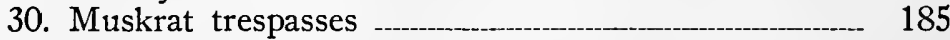

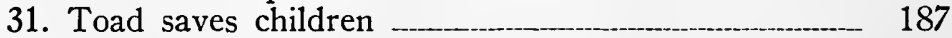

32. Chipmunk and Snake (Contest for Winter and Spring

189

33. Elk and Snowshoes _-________ 190

34. Contest between Cold and Heat _._____- 191

35. Rabbit and Jack Rabbit _________________ 192

36. Dog goes for fire - 193

D. Tales with historical elements ___________ 194

37. Turtle's war party (Mock Plea) ___________ 194

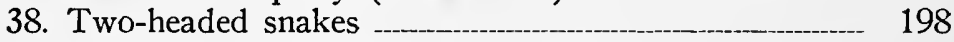

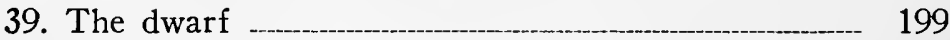

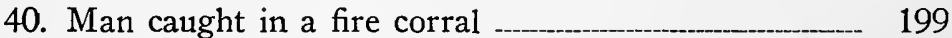

41. Flathead chief sends his daughter to Chief Waxane' 200

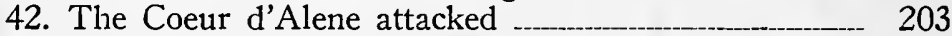

43. Two women overcome Nez Percé man _._______ 206

44. Woman saved by loose saddle cinch _______-_ 207

45. The Coeur d'Alene fight the Kutenai ________- 208

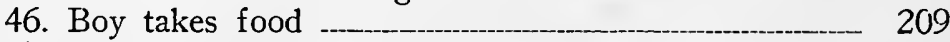

47. The practical joker _.__________________________ 210

48. War between the Blackfoot and the Coeur d'Alene _- 211

Bibliography and Abbreviations 


\section{CHAPTER I}

\section{INTRODUCTION}

The myths and tales presented and analyzed in this volume were recorded in text in the years 1927 and 1929. They were secured from informants characterized in greater detail in Chapter II. The Coeur d'Alene were described by James A. Teit in 1904 (ARBAE 45 :23-197) and tales closely resembling these were published in free translation in 1917 (MAFLS 11:119-28). Since the Coeur d'Alene culture was at best loosely integrated and since such knowledge as we have of them was secured long after they had changed their original way of life, the material here given aims to supplement Teit's and to show how such supplementation may be ascertained through linguistic and folkloristic methods. Instead of using different material it depends upon analysis and synthesis of evidence made available at different times and through different means.

The Coeur d'Alene Indians live in the so-called Plateau area in the northern part of Idaho and have been easily influenced by intruders. Before the coming of the Whites their whole economic and social life was changed by contacts with the Plains Indians who lived across the mountains. The most important white influence, and that an indirect one, was the introduction of the horse. After the Coeur d'Alene had secured sufficient horses they took to buffalo hunting on the Plains, which involved difficult travel and long absences from home and perhaps added little to the food supply, being in the nature of a sport rather than an economic activity.

In the little more than eighty years since the Whites have been actively concerned with changing Coeur d'Alene ways, most of the old culture has been stamped out. That which the Indians now have is neither white nor Indian but a doubtful residue of both. The Indians own large ranches which they rent to Whites; they live in houses like those of white men, dress like them, eat their kind of food and perform their religious ritual, in short, try to behave as Whites. The most apparent difference is social. The Whites for the most part consider the Indian a subject for exploitation, use him accordingly and scorn him by every conceivable means in their power. The Indian on the other hand defends himself by apparent stoicism, stolidity and passive resistance. $\mathrm{He}$ realizes that he is being exploited but is defenseless. His only compensation is the 
privilege of privately pointing out the mistakes of the Whites and gloating over their absurd conceits.

In the short space of eighty years these Indians have changed from food gatherers and hunters of small game to horsemen and buffalohunters, to farmers and, finally, to owners of land which they do not themselves use but from which they live through rent from Whites.

In the accounts of their early life the subject of religion is almost entirely neglected. In 1928 the Sisters of Charity of Providence celebrated the fiftieth anniversary of their residence in Coeur d'Alene territory. The Jesuit Fathers had preceded them by some thirty years (1846) when they founded a church at Cataldo, Idaho. It is not surprising then that the Indians who are Catholics know almost nothing of their old religion. Since that religion was not very tangible and since there is little missionary sectarianism in the region, it is not difficult to understand why the efforts at Christianizing were largely successful.

Many of the facts of Coeur d'Alene ethnology recorded by Teit are now unobtainable and we cannot sufficiently acknowledge our indebtedness to him for rescuing even fragments while there was still time. All of those customs recorded by him which were still remembered in 1929 are accurately set forth. In some cases informants were interested to learn about the customs of their forefathers, since no one then living knew of them except through legend. The only part of Coeur d'Alene culture left in 1929 was the language, which survived among the old people and was preserved in the mythology which also has many evidences of white influence. By this time (1946) many of the old people have died. Few of the young are interested in these matters and the last vestiges of the culture are rapidly disappearing.

Among the survivors of a dying culture there are always those who value it. I was fortunate in making the acquaintance of Mrs. Julia Antelope Nicodemus who was one of these. She was the daughter-in-law of Teit's chief informant, Nicodemus, and his wife, Dorothy, my informant. Julia did everything in her power to aid me in my work, for she quickly comprehended the problems of linguistic analysis and was greatly intrigued by them. Her work as interpreter is obvious in the translations and grammar (HAIL 3:515-707) and, not only did she furnish all possible information of which she herself was possessed but she referred more difficult matters to her mother, Susan Antelope, and her brother, Maurice Antelope, with whom I did not work directly. She encouraged her son, Lawrence, to come to New York a few years later when he collaborated in the work of preparing the grammar. Without 
Julia's thorough understanding of the task and her valuable advice as to ways of going about it my results both linguistic and mythological would have been much more scanty.

The two chief narrators, Dorothy Nicodemus and Tom Miyal, are described in Chapter II. Julia was my interpreter for their tales. She learned to write Coeur d'Alene and contributed the historical narratives, Nos. 42 and 46, as her own compositions written in Coeur d'Alene.

The work of this volume has various purposes. It aims to show what texts have to offer to knowledge about a tribe which cannot be secured with free translations alone. If this type of knowledge is to remain implicit only, it is likely to be lost entirely; consequently considerable time was given to ethnological sounding-out of mythical and linguistic clues, the results of which are given in Chapter III which follows the plan of Boas' studies of cultural reflections in mythology (ARBAE 31 and MAFLS 28).

Professor Boas often discussed the possibility of determining the literary style of various myth bodies (explicitly in RLC 491-502 and by references in numerous other works). Much of the effort of folklorists has been directed to problems of diffusion and assimilation which have become more seductive as more regions are studied and analyzed. It is my opinion that style is the distinctive feature of a myth body, that which sets it apart from other comparable bodies of tradition, and that, with a number of mythologies analyzed for literary effects, new diffusional problems will become apparent. Such a procedure would do more to separate internal and external factors which make for change than the mere tracing of plot.

This does not mean that I minimize the value of the studies of plot diffusion but rather that, once they have been made, their conclusions may be checked and reinforced by adding this approach. For this reason a modest comparative study of similar tales and literary devices in a northwesterly direction has been added to many of the stories here reported. The significance of occurrence of similar plots, episodes and motivation in any direction except that of the northwest is doubtful, since only those references are given which have been worked out elsewhere in the material used. The limitations of the comparison are not condoned, they are merely explained as necessary because of lack of time and other facilities. The comparison is useful in fitting the Coeur d'Alene into its proper position as a tribe of the northwest and even as pointing out certain affiliations to the east and south, not to mention the use they have made of European myth material. 
While plots, ${ }^{1}$ but more commonly episodes ${ }^{2}$ and elements, ${ }^{3}$ are European. Individual temperament also influences such matters. Dorothy, for example, took great pride in remembering the archaic form of some of her stories, even though in some cases she did not understand parts of them. Tom Miyal, on the other hand, depended on modernizing for his most humorous effects.

'Turtle's War Party (37) has the Mock Plea plot of the Brer Rabbit story although the motivation of the story is in some respects historical.

${ }^{2}$ Finding berries in winter (14), Catbird fishing wish (22), Girls finding cooked camas on door (Hansel and Gretel) (8), Coyote fears his shadow (Aesop) (3).

${ }^{3}$ Lynx's child is illegitimate (9), Boy's encounter with beautiful woman in bright light (42). 


\section{CHAPTER II}

\section{' 'he Style of Coeur d’Alene Mythology}

\section{THE PROBLEM}

The following discussion is a stylistic analysis of the myths and tales. Not all of the text material in existence is suitable for studies of style and it is seldom that translations can be used for fair conclusions. The difficulties of obtaining texts in writing make it almost impossible to get full versions. Informants get bored with requested repetition and summarize briefly what they have said with remarks like, "You have it already," "It is just the same." Furthermore, and perhaps more important, the incentive of atmosphere is lacking. Narrators are ordinarily stimulated by firelight, leisure, an audience with an understanding of the setting. Linguists tear them away from work or play, which they prefer, to sit and tell stories without listeners in broad daylight, usually in summer when there are more active things to do. Often the tribe has a theory that tales should not be told in the summer, but nowadays the Indian seldom holds to the rule although he may fall back on it for an excuse if he tires or does not want to tell them. Informants sometimes get interested in recording for its own sake as was the case with various informants I have used. In spite of the drawbacks more of the native spirit in the tales may be ascertained if the study is made through texts than through translations alone, a method which is emphasized in this analysis.

The small collection of Coeur d'Alene myths made by Teit (MAFLS $11: 119-28$ ) gives an adequate idea of the range of plot, episode and elements of Coeur d'Alene literature. This collection is published with the myths of a number of other Salish and Sahaptin tribes in the neighborhood. There are few except the most obvious characteristics which would serve to indicate any difference in style among these tribes. Since this difference is existent the literary analysis of texts aims to discover it; it includes the kind of effects the Coeur d'Alene narrator seeks and ways in which he achieves them.

Compared with other North American tribes the body of Coeur d'Alene literature is not rich. Teit in his short presentation of free translations gives a good cross-section of the types of narrative. In this collection there are thirty-eight myths, that is, accounts of things as 
they happened before the world was as it is now ; two tales or accounts of happenings in the historical period; and ten narratives of actual historical encounters which were remembered by living people or which happened not less than a hundred years ago. I have classed Nos. 37 and 38 as tales because the Indians did so although they have many obviously imaginative characteristics. The plot of Turtle's War Party (37) is widely used in the Plains area but it has an additional interest in that the Nez Percé chief here said to have been scalped by Turtle was really scalped in such a mysterious fashion that the culprit was never caught. The brief description, The Two-headed Snakes (38), is vouched for as an absolutely true story. Dorothy's father saw these snakes. Each one had two heads on each end of its body and it was necessary for it to move like a scythe so that the heads could be kept in the proper position.

Some of the historical accounts, especially those about war, are almost identical with those collected by Teit. The specific references are given with the separate stories.

Among many tribes, for instance, in the Plains, the Northwest Coast or the Southwest, informants are fairly bursting with tales. It is not unusual to collect a large number from one informant and from another an equal number or even more. Most of these may be different too as various individuals specialize in different types. Among the Coeur d'Alene such is not the case. Each narrator is likely to know all the tales or nearly all of them and the individual versions do not vary greatly in plot. The general impression is that the myth body is small and greatly influenced by neighboring Indian lore as well as by the Whites.

PLOT

In discussing plot I shall assume that a running narrative which may or may not be closely knit consists of a number of episodes, any of which may exist independently of the long narrative in which it is found. It is usually to these episodes that the catchwords apply. The episodes in their turn are composed of elements which may be closely concerned with plot, purely stylistic or performing functions belonging to plot and style alike.

An illustration is the following. The phrase "You shall no longer be a man-eater" is an element used so frequently as to be a feature of Coeur d'Alene style, but it is also the concluding phrase to show why the preceding action has been carried out, thus having some importance in the motivation. There are elements which have nothing 
to do with plot, such as the touches which a lively narrator like Tom Miyal introduces for the sake of humor. Waterbird sticks the handkerchief given him by the chief's daughter into his coat pocket so that one corner shows. This element merely verbalizes a human conceit. The Land People phone up river to Snake. This is an amusing reference to the way white people do things. There are other modernizations which seem like purely stylistic elements but which have additional significance. For instance Waterbird became a dishwasher through shame at forgetting his appointment with the chief's daughter. $\mathrm{He}$ thereby put himself in the position of the Humble (though successful) Suitor and his act affects the entire plot (26). The same character, as the husband who does all the work, sets forth to overcome the Snakes who had kidnapped her just because he was unnaturally overwhelmed with housework. ${ }^{1}$ In these cases the simplest elements really function significantly in developing the plot. These examples are markedly European but they serve as illustrations which do not differ from the purely native elements used in the same way for the same purpose.

European folklorists have long been interested in aetiological tales. Waterman ${ }^{2}$ showed quite conclusively, I think, that explanations in many North American mythologies may be considered stylistic rather than motivating. In most cases the explanatory elements in Coeur d'Alene mythology do not influence the plot. In some cases they seem even to be forced into the narrative. The argument that the desire to explain was the reason for the origin of the myth is exceedingly weak here. Two of the tales, The Story of $\operatorname{Lynx}(9, \mathrm{a}$ and b) and Child of the Root (1) might be considered as aetiological in origin, but they are not convincingly so. The reason that Lynx's fur is straggly around the neck and paws seems to be quite dominant in the Coeur d'Alene mind, but the achievements of Chief Child of the Root in making the world generally habitable are much more important to the Coeur d'Alene than details as to why Mudhen has burnt eyebrows or why Kingfisher is now a good fisherman. The main stress in this myth seems to me to be moral: If one addressed the Transformer as "Chief," he was blessed; if he addressed him as "Chief Child of the Root," he was subdued or even destroyed. One of the important purposes of the Chief's work was to teach food conservation. "Don't take one too big or too small, take just the right size. Then eat it all, do not leave any!" is a constant admonition. And again, do good for the people. "You will no longer be a man-eater. You will be used. ..."

\footnotetext{
${ }^{1}$ Among the Coeur d'Alene the women do the housework. It is considered shameful for men to have to do it.

${ }^{2}$ JAFL $27: 1-54$.
} 
Moralizing as an obvious reason for myth-telling is not common in North America and it is doubtful if it is ever a single explanation of myth origin. The story of Child of the Root alone illustrates how moralizing and explanation may be almost purely stylistic rather than motivating with both used in nearly equal proportions.

Since some Coeur d'Alene explanations are unique, a list of them is here appended:

Nighthawk's head became flat, his mouth was stretched out wide and pinched together at sides by a rock which Coyote put on his head (19).

Cricket has stitches on his body because Coyote sewed him up (18).

Coyote was burned around the eyes by Antelope. Antelope has narks on his legs and at the root of his tail because Coyote retaliated by hitting him with a lighted stick (3).

Meadowlark secured necklace and locket (3).

Peculiarities and origin of different tribes explained (2).

Child of the Root made Kingfisher's nails long and cut his bill in the shape of a file (1).

Lynx's feet and neck have long shaggy hair (9a).

Buzzard has white and red eyes because Lynx's wife choked him (9a).

Otter clubbed Muskrat until his head became flat (30).

Girl gave Mudhen a dentalium, hence the shape of her nose (24).

Helldiver and Robin have white streaks on their breasts. Robin's sound speaks of death, Helldiver likes water (24).

Crossbills have twisted mouths because they mocked Coyote (7).

Catbird has small eyes because of Coyote's eye juggling (7). Coyote tore his eye pulling off Old Woman's dress, pressed the tear together, thus making the hair stand out. Coyote has rust around his eyes because he ate forbidden medicine (7).

Birds became wild canaries when Skunk squirted fluid on their feathers and made them yellow (23).

"Right now at Salmon's head there is an arrowpoint" because Salmon was shot in the war between the Land and Water Animals (10).

\section{ACTION}

There is a great deal of purely formal action, that is, certain acts are performed in a conventional way. Things which have been destroyed are renewed or righted by smoothing. Meadowlark calls attention to her presence by placing her legs across the trail. They look like nice smooth little sticks. The person in trouble steps on them and breaks them. When she complains he puts them in place and smooths them, whereupon they are restored (3). Coyote, after he has caused Cricket's death, stitches him up, smooths the stitches, steps over him and he lives again (20). Chief Child of the Root smooths Splinter Leg's leg and it becomes whole (1) ; Coyote's treatment of Cricket is typical in its extension (18). A person who has died may have the parts of his body scattered about in 
all directions. The pieces are assembled, smoothed, stepped over and the individual comes to life $(1,3,4,10,17,18,22)$. Coyote, who constantly gets into mischief, is resuscitated by his friend, Fox. Coyote usually yawns, "My, I've had a nice long sleep !" and Fox replies, "You weren't asleep, you were dead."

The method of reaching land under water is always the same. The people going there get into a canoe in definite order. The first one in is the one to steer. Then at a signal the canoe with all its contents dives. It dives four times, the last time arriving at its destination. If Coyote is one of the passengers, he wants to be first. He always dives flat and blames his companions for pushing him but, whether or not he is first, he can hardly stand the deep dives and he comes up gasping each of the four times. The last time he has barely enough breath left to survive $\multimap$ of course, he always does survive!

There is formality of setting as well as of behavior. Villages are located near bodies of water. Travelers in canoes sight a house or a village, come ashore, walk up the beach, look into or enter a house. The houses at the bottom of the water are inhabited by man-eating monsters (the translation "whales" is incorrect). The house is made of ice and snow and the space from shore to house is glittering with ice which can be traversed only with the aid of magic power $(10,22,27)$.

The above examples illustrate the use of formal elements not closely related to plot. Plot development in these cases does not depend upon these conventionalizations. There are however formalities which set the action in motion after it has apparently halted. One of the most common motivations is desertion. An individual is deserted. He sits down, covers himself with his blanket and thinks, "No person, no house, no blanket, no food. I will surely die. If I go away, I may run into danger. If I stay, I will die of starvation. If I go, I'll die; if I stay, I'll die." For days-"I don't know how many, but about two"-he lies dejected, careless of self, mourning. When the period of mourning is over, he jumps up, goes to the sweathouse, then to the river to start all over again $(1,5$, $22,26,28)$. A person with peculiar power may, after observing this ritual, reach into the water, pull out a monster, take a part of the head shaped like a canoe and use it for one in which he escapes his fate. With it all sorts of adventures may be entered upon.

Coyote, after a grievous experiment, mourns louder and longer than anyone else. After a time the people pity him, perhaps even give in to his demands. They go to seek him because his cry sounds weaker and weaker and they think to save him from absolute exhaustion. They find he has left his spittle to cry for him, while he is up and away at new deviltry $(3,7)$. 
A boy, usually unruly, foolhardy or both, fishes. He fishes up something surprising-a woman or child. He runs and tells his grandfather who warns him against bad luck; he does not take the advice and puts himself in the power of the monsters who inhabit the icy shore under the water $(10,22,27)$.

An individual draws his blanket up to his face, sits or lies without glancing up, refuses to answer any questions until one is asked which confesses guilt or contrition on the part of the questioner. The person concerned racks his brain for all possibilities and when he finally stumbles upon the offense, the offended one reacts by answering and accepting the apology or the atonement $(1,4,7,13,16,27)$.

Behavior of the sort described causes a turn in the plot and for that reason is mentioned here. It may easily be seen from these illustrations that a fine distinction between elements and episodes cannot be made, for elements which may consist of only a phrase or two may have an important bearing on the plot, or a formal combination of elements which might from its length be called an episode may play little or no part in plot development.

Episodes or incidents are combinations of elements dealing with action which may be considered entities if used alone. The Bungling Host, Eye Juggler or Coyote Frightened by his own Shadow are examples. All of these may be found in other myth bodies as separate tales; sometimes they are much expanded. The first is an independent story in Coeur d'Alene; the others are merely incidents of a longer and more complicated narrative. In some cases the combination of such episodes is unified. One episode is used as a natural outgrowth of another. Another plot device is to recount the doings of characters in different places, while one is going through the actions of one episode, another is concerned in a different one. It is however quite common to find a succession of episodes not necessarily related to one another strung into a long narrative, sometimes without much apparent point.

The style of different tribes differs greatly in this respect. Some mythologies have few, if any, long myths whose plots are not closely unified. Others center their interest on the episodes, feeling little or no necessity for unification or consistency. The Coeur d'Alene mythology stands about midway between these two extremes. Some of the tales are splendidly unified ( 9 , for example); others are scattered and sprawling in the impression they leave (8).

The abstracts show distinctly the episodes known to the Coeur d'Alene. Among them are such wellknown ones as Rolling Rock (19), Origin of Indian Tribes (2, common to many tribes of the Northwest area), Bungling Host (14), Test of Fatherhood (9a, b), Box Dropping from 
Sky (4), Calling the Deer (16), Eye Juggler (7), Releasing Salmon (8), Dog Husband (11), Mock Plea (37).

Several of the more unusual ones are the incident of the Kidnapped Baby (24), Friendship of Rabbit and Jack Rabbit (35), Story of Thunder (25), Dog Goes for Fire (36).

Devices used to weld the episodes together show that unification of plot is valued. Trickery is resorted to when the action comes to an end and there seems no way of setting it going again. The old familiar ruse of making a dummy to take the place of someone is used $(22,24)$. Coyote becomes a weird foundling in order to release salmon dammed up by four man-eating sisters. The mother of the kidnapped boy throws her belt upon the water for pursuing man-eaters to use as a bridge. When they are on it with their clothes full of rocks (which they are told will steady the belt), the mother pulls it in and the man-eaters are drowned. Grizzly challenges Rabbit with whom he lives to contests, pretending they are play. Rabbit substitutes a bladder for his eye and thus saves himself from Grizzly (2). Catbird pretends to offer Wolf a large lump of fat. It is really a hot rock wrapped in elk fat (22). Geese try to kill Little Mosquito with thornberry prods when he is hiding in the sweathouse. He mixes red paint in his little spoon and puts it on the end of the thorn sticks and they think he is dead (28).

One of Coyote's most important functions in myth is playing tricks on others. His tricks sometimes revert to his own discomfiture, but often he succeeds. Two will suffice as examples. As a result of consultation with his powers, he causes his son to reach the sky by lying down and arching his eyebrows. Coyote pretends he does not want to do this but cannot help it because he is afraid his son will fall from a tree where he is gathering feathers from an eagle's nest (4). His trickery may be direct lying as in the case where he pretends Gobbler spat up the two mice and he himself the two nice-looking people when really the reverse was the case (2).

Although trickery is one of the important devices used by the Coeur d'Alene in plot development and in combining episodes, the tricks themselves are not unusual but rather the conventional ones known to and used by many other Indians.

There are occasions where deceit, though necessary to the plot, is nevertheless punished. The Grizzlies were a group of deceivers aided and abetted by a traitor Coyote. Little Beaver overcame them with strength he secured through training (5). There is a strong sense of poetic justice in this tale. Coyote sometimes gets his deserts and when he does, the satisfaction is great to myth characters and to their creators. He was punished by drowning for disobeying the Geese brothers (13). 
He was killed by grizzly cubs for breaking a taboo. Fish took him at his word and he had to entertain them all (8). In the encounter with Lynx he and Raven came off worst because they had stamped on Lynx maliciously $(9 a)$. Coyote was destroyed by his son for his bad treatment (4). Woodtick, after helping him, forsook him and let him starve (16).

The most drastic measures used against Coyote are merely temporary in their results. With his power of invulnerability he always becomes alive and is just as tricky as ever but, because of his eternal resiliency, he furnishes the myth-maker with material with which to spin an infinite number of tales.

Good deeds may also be rewarded, although examples are less numerous than are those of punishment. Rabbit and Magpie were rewarded for returning with their blankets for Lynx's baby when it and its mother were helpless $(9 a, b)$. The man who deceived the girl sent to Chief Waxane' and all his family were destroyed by the chief (41). The most obvious and frequent exercise of justice is by punishment of the guilty-it is most often death or destruction-whereas the reward for good deeds, though not lacking, is rare. The reason for this treatment is to be found in Coeur d'Alene psychology. The first reaction of the Coeur d'Alene for even the most trivial offense is, "I will kill (or injure) him." There is of course no way of telling whether the tales reflect this attitude on the part of their narrators or whether they have this attitude because of the constant influence of the tales. The effect is doubtless reciprocal.

Such a question as that of poetic justice must be looked at with qualifications, for that which might seem just to us might seem to the Coeur d'Alene mere foolishness. The story of the boy who stole the food (46), for instance, takes on a very different moral tinge from the same offense in our milieu. The point of the story is that it is bad for parents "to think more of food than of their child," and they are punished accordingly. The action of the boy is condoned and he continues his adventures successfully.

Trickery and poetic justice may give the plot its motivation and they are also important in plot development. A third device which is purely stylistic and has nothing to do with motivation is the use of warning or rehearsal of a scene and the repetition of that scene in actuality. A protagonist gets into a tight place. A deus ex machina reviews for him what is going to happen and in so doing stresses the part the protagonist is to play. Everything happens as predicted $(3,8,10,22,24,27)$. This type of repetition without supernatural help is used when an individual plans out his action in his mind, then performs it $(1,8)$. Although the 
device is principally a rhetorical one, it nevertheless influences the plot development.

\section{PLOT MOTIVATION}

The plot motives are not unique among Indian mythologies. There are however limitations to the number and kind used. Of these by far the most outstanding is that of punishment. Someone offends either purposely or inadvertently and must be punished. The two most common punishments are desertion and killing. Chief Child of the Root leaves his mother and grandmother because of his mother's offense in giving him a root for a father (1). The girls who stole dentalia from the chief, their father, are deserted (24). The younger sister is deserted by her older sister because she fails to pass the food offered her through a dentalium funnel (24). Lynx's wife is deserted apparently because of the illegitimacy of her child $(9 a, b)$. His grandmother leaves Catbird because he is stingy and does not share with her the fish he caught (22). A girl who does not learn to work is left by the whole village (31). A younger sister and her dog-husband leave her older sister who taunts her about her husband (11). Elk leaves his partner, Snowshoes, because he does none of the work (33). An exaggerated case is that of Coyote even thinking evil of Little Beaver, whereupon he is left alone (5).

In these motives there is some idea of revenge which is also the chief motivation of some tales as Coyote's theft of his daughter-in-law (4). The perfect vindication in Coeur d'Alene thought is destruction by killing, either the individual being considered guilty $(13,16,33)$ or his whole family or village $(5,7,22,24,27,41,46)$. In the story Muskrat Trespasses (30), Muskrat avenges himself on the Otter boys by killing their sister. Retaliation may also be made by burning the house of the offender $(1,28,37)$. Milder forms of revenge are counter-trickery (8), or beating $(24,34)$. Chief's orders are considered important by all good citizens of a village and disobedience is punished $(7,8,13)$. Obedience is exacted by an older person from a younger, unless that younger has special power (24).

Other motives which set a long plot going are the power of the little $(1,5,16,28)$ or ugly one $(8,11)$, contests of power, test $(5,16,28)$ and unsuccessful imitation $(7,8,14)$. Almost all the tales have these motives in one form or another. Just as the plots themselves and even the episodes which compose them show little originality in comparison with Indian mythologies in general, so the motivations are not unusual or greatly varied. Desertion, punishment, revenge, disobedience, tests of power are the most frequent; often one gives rise to another and the combinations give variety to the stories. 


\section{CHARACTERS}

The characters in Coeur d'Alene mythology are of three kindshuman, animal and characters neither human nor animal. Of these the animal characters are much in the majority. The whole order of literary actors is fixed in the Coeur d'Alene mind so that it is not always possible to differentiate humans from animals. Two formal introductions to the tales are, "There was a village. There was a chief" and "A boy lived with his grandmother." Such introductions sound as if the actors were human but they are not so regarded. In the first instance the chief is understood to be Bald Eagle and the inhabitants of the village animals and birds of different kinds. The boy and his grandmother are almost always animals or birds. Although in many cases the informants cannot tell which animals are related to the chief, they feel nevertheless that they are animals and not humans. In the age in which the myths are set, animals were people and people were animals. There was little differentiation, and animals had the good or bad characteristics which we now ascribe to people in addition to the characteristics now possessed by the animals themselves.

Occasionally actors seem to be human, but they are rare. Chief Child of the Root (1), Splinter Leg (1), Chiefs Reserved and Quiet (10), and the Nez Percé chief (37) were human. The girls who stole dentalia (24) may have been human, but were probably birds. The hunter whose wife was stolen by Thunder (25) is not given an animal name, but it is quite likely he is thought of as one. The same is true of the deserted girl and her little brother who were saved by Toad (31).

Actors which are neither animal nor human may be normal. They may be natural phenomena such as Sun (3), Rock (19), Wind (21), Cold, Heat (34), Thunder (25). They may be manufactured objects as Pestle, Awls, Combs, Bladders, Lassos (1), Snowshoes (33), or they may be highly imaginary creatures, monsters which have animal or human characteristics but are larger, fiercer and have additional abnormal features: the Child Eater (31), Gobbler (2) and all beings referred to as water monsters $(1,22,27)$. These beings are almost certainly the "mysteries" described by Teit (ARBAE $45: 181-2$ ) with more details than the stories furnish.

Along with the belief in "mysteries," monster-spirits, or whatever they may be called, is a belief in dwarfs. They are small supernatural beings which frighten men, do them mischief, but rarely if ever cause lasting damage. Strong as this belief is in the Coeur d'Alene mind it is strange that dwarfs do not occur in the myths. The brief description of tale 39 is the only evidence of their existence in this collection and it 
was asked for and given, not as a myth or a tale but as a piece of description.

The Coeur d'Alene in their original environment lived by hunting, fishing and food-gathering for they knew none of the arts of agriculture, nor did they domesticate animals. They inhabited territory where game and fish were abundant, their homes being near wooded river and lake shores. The men spent a large part of their time on the water or in roaming the forest. Much of the women's time was employed in gathering roots, seeds and materials for housebuilding and basket- or wallet-twining. Even when they remained at home there was ample opportunity for observing the behavior of birds and animals. Consequently they became authorities on bird, animal and plant habits. The most exacting details can be given even today by those few Coeur d'Alene who still cultivate their liking for hunting and fishing. In the summertime it is sometimes difficult to find the conservative families as they are constantly going camping for the purpose of gathering. It is no wonder then that they feel themselves intimately related to the animals or that their descriptions are reliable. These conditions account readily for the use of animals as actors in the myths, but they do not explain the absence of plants as characters. There is no reason to suppose their knowledge of plant life to be less intimate or exact, yet in only one case is a plant considered anything but an inanimate object. And this is true in the face of the fact noted on page 14 that life and action were easily ascribed to other natural phenomena and to manufactured articles.

There is a large number of animal actors, but I suppose that if a list of known animals were compared with a list of those used in the tales, many would be missing. For instance, one of the most common birds in the Coeur d'Alene country is the killdeer. It is much loved by the Indians. There is however no story connected with this bird and it appears only incidentally as one of the man-eating sisters who dammed up the salmon (8).

Coyote is the most outstanding actor in the myth body. There are few narratives into which he does not enter either as a primary character or incidentally to put a spoke in somebody's wheel. Fox is Coyote's closest friend and appears often with him or helps him if he is in trouble. Their pet enemies are the Wolves and there are frequent conflicts between the two parties. Grizzly Bear, a fierce fighter, vies with these animals in the number of times he is mentioned.

Other mammal actors are: antelope, deer, elk, beaver, otter, mink, muskrat, fisher, badger, skunk, lynx, black bear, rabbit, jack rabbit, various squirrels, mole and mouse. 
Birds are also numerous: nighthawk, meadowlark, foolhen, mudhen, geese, black swan, kingfisher, magpie, raven, woodpecker, redheaded woodpecker, helldiver, robin, pheasant, tern, crossbill, snipe, catbird, eagle, crane and several others which have not been identified. ${ }^{3}$

Insects mentioned are: cricket, mosquito, spider, an insect like a spider with long legs, perhaps harvestman, woodtick, louse, bedbug and a former but now outdated pest, perhaps flea.

Fish and reptiles are usually classed as Water People, but Snake and Toad were Land animals. Salmon was the chief of the Water People and some of his followers were Turtle, Watersnake and the Fishes.

The organization of the animals into kinship groups is a stylistic feature of the area including many tribes besides the Coeur d'Alene. Relationships are understood by all the people and it is not always necessary to mention them in the tale. Bald Eagle as village chief and the animals as the villagers have been mentioned. A boy lived with his maternal grandmother $(8,22)$. This is exactly according to Coeur d'Alene custom even today. As the interpreter explained, "There is always a grandmother on the mother's side in the stories because she took more interest in the family."

Complex organization is mentioned for some families. Coyote's wife was Mole and they had four sons and a daughter. These children have names which may also be applied to humans. Four mice were Coyote's aunties. Fox was his best friend and he reckoned numerous others as relatives by his remark, "Your father's father's father and my father's father's father were brothers, so we must be brothers." He addressed Cricket as "younger brother." This may have been sarcasm, teasing or a form of coaxing.

With Coyote lived, according to different stories, Deer and her two children (6) ; Antelope and her four children, until Coyote and Antelope quarreled (6); Fox (with Coyote and his daughter, 12); Badger and her children (15).

The only consanguineous relationship of Fox mentioned is that he was the maternal grandfather of the cruel boy of tale 27 . Coyote and Fox had a special term which they used reciprocally. It was a contamination of the word for friend (I have translated it "boy-friend," although I do not think it particularly good).

Another relationship mentioned is that of the Otter brothers whose sister was Mink (30). Cold and Heat were brothers (34). There were four of the Geese boys and Pine Squirrel was their only sister (13). Harvestman was the father of the Beaver Girls (4). It was common

\footnotetext{
${ }^{1}$ In most cases identifications were made from P. A. Taverner, Birds of Western Canada, Victoria Memorial Museum Bulletin, No. 41. 1926, Ottawa.
} 
for several families to live in the same house. Several examples of this custom have just been mentioned. Elk lived with Snowshoes (33); Rabbit and Magpie lived together at some distance from the Chief's house (9); Skunk and Fisher inhabited the same house (23).

In my opinion the nicest relationship in Coeur d'Alene-and in any group for that matter-is that which may be translated "relative and friend." Rabbit and Jack Rabbit bore this relationship to each other (35), and there can hardly be found a tale so full of psychological insight as the one which deals with the worries incident to the separation of these two who were bound by a deep friendship but who happened to be relatives.

As is the case with other raconteurs, the Coeur d'Alene narrator sometimes finds himself in need of a deus ex machina, nor does he want for one. Three different characters perform this function. Meadowlark, a wise but tiny helper, appears just in time to save the protagonist. $\mathrm{He}$ is desperate when he sees two nice smooth little sticks lying across the road. Unheeding he steps on them and breaks them. Then he hears, "aninin, you broke my legs, I was going to tell you a story." "Oh, I am sorry! Do tell me a story!" and he places them together, smooths them and at once they are healed. Then Meadowlark predicts what is to happen to the hero and the hero proceeds according to her directions $(1,3,10$, 24).

Coyote had helpers which could predict his behavior. When he came to an impasse, he summoned them. None of my informants could (or would?) tell me exactly what these helpers were. They always said, "That's a Coyote-word." The Thompson (and other Salish tribes) attribute special powers to Coyote's excrement. From linguistic evidence I suspect the four powers are excrement, testes and penis. Coyote has a special kinship term by which he addresses them. This term is used nowhere else. The first power offers to take some special part of the burden of attack, the second assumes responsibility for some other part and each of the others contributes its share to make the adventure successful $(2,3,4,5,8,14)$.

When a boy has been unwise enough to wish while fishing and draws up a woman he brings bad luck upon himself. He reports his luck to his maternal grandfather who, by his magic, saves the grandson from the water monsters into whose power he has come $(22,27)$. The grandfather knows that the water monsters are dangerous and is able to advise the party which accompanies the boy what to do and what not to do. Furthermore he is able to walk up the beach made of ice, snow and frost which extends from the shore to the house, the monster's under-water home. 
These supernatural helpers are not used indiscriminately or frequently enough to be tiresome. No one can use Coyote's powers but himself. There are times when he does not (or cannot) use them. In the story Coyote Loses his Eyes (7) he is constantly helpless and in trouble and always dependent upon someone to help him out. The motive here is punishment for his misdeeds, especially for his ingratitude and, if he could summon his powers to his aid, the story would have no point.

Meadowlark can help anyone and, in the tale of the Animals Obtain the Sun Disk, Coyote is aided first by Meadowlark and then by his powers. The grandfather with supernatural power has this power only over deep water and the country under it.

A number of other helpers or actors give directions as, for example, Chipmunk and others of the Squirrel family $(8,23,25,32)$, Woodpecker (7) and the Spiders (4). These are, I think, actors which come into the story in a natural rather than a supernatural way, or they may be equivalent to guardian spirits, as Chipmunk certainly is.

There are myths where no intermediary is needed. Lynx, for instance, has quite enough power to help himself out (9). Catbird helps himself by his wit, fearlessness and calculated naiveté (22). Crane, like Lynx, has strong power as well as wisdom (8). There is therefore no lack of variety in presenting solutions to the conflicts which arise in the plots.

\section{CHARACTERIZATION}

Almost every quality is inherent in the character of Coyote, who is the most versatile of them all. All other characters are stereotyped but he may appear in any guise. His good qualities are not absent, but whenever his motives seem good they should be regarded with suspicion. If they do not suddenly change, they at least rarely reach attainment because of Coyote's stupidity.

$\mathrm{He}$ is greedy. His greediness reaches its climax when he is not satisfied to devour Deer and her children and his own sons, but even eats the scraps he has offered to his baby daughter before she can eat them herself (6). In another repugnant incident he eats his own marrow after having broken his leg (7). He is indignant at the Crossbills for taunting him about it and as revenge, pulls their bills diagonally so they can no longer speak words. The examples illustrating Coyote's greediness show also his cruelty (6). There is no limit to the length he will go to gain even an insignificant end. He banishes his son from earth for a long time to get his wife (4) ; he brings disaster to the people for only a whim (17), he does all in his power to punish Lynx 
whose offense against him is not mentioned (9); he even kills Badger, his own house-mate (15).

Coyote is the personification of ingratitude. Even when he is in the direst straits he mocks or complains. Woodtick furnishes him with halves of deer when he is starving. He complains because the whole deer is not given. Although she gives him his only means of subsistence he teases her because she has no neck (16). When he has got himself into the tightest place because of his greed at a dance he tries to steal forbidden bladders of fat which turn to rocks and cover him. A woodpecker, by dint of the hardest work pecks a hole so he can at least see. Coyote, looking through the hole, sees Raven and cannot resist pointing out his deformities, whereupon Raven picks out both his eyes and he is worse off than he was before (7). Lynx, in a burst of forgiveness and generosity, takes back the entire village after they have wronged him. Coyote finds only bones and fat in his house and complains even though he has had no other food for days $(8,9)$.

Coyote is boastful, vain and stupid. Never is a test announced that he fails to brag of his prowess or that of his children: "My beads are the nicest"; "my first-born will be the first to break it" (26); " $I$ am the child's grandfather" (9); "I am the one who really knows how to gobble" (2); "my father and his father and then his father knew that trick too" $(2,7,8)$. In most cases Coyote is bested, but there are occasions when his opinion of himself is justified as for instance in his contests with Gobbler (2) and with the man-eating sisters (8). His defeat is due to stupidity, thoughtlessness and lack of foresight. $\mathrm{He}$ is so vain that he frequently disobeys taboos or orders. He cries out when the Geese have particularly asked him not to (13); he takes pride in disobeying the chief's orders (8); he tries to shoot more than two deer and comes off with only two fawns (8). He is vain about his appearance, "When I go to Spokane how nice I shall look"-this, in Nighthawk's coat (19). His vanity may be a source of philosophy and comfort, as when Mole has thrown the plates into his ears, "Oh my! I have a nice noise in my head. When I get to a celebration I shall be called, 'The One with the Noise in his Head' "' (6).

Suspicion is naturally a part of his nature. He illustrates well the saying that one suspects motives in others which he himself may have. Thus when Nighthawk tells him to hold fast to his belt he is afraid to trust him (19). His great faith in his own power may be the reason he does not believe that of others to be strong. Although he is suspicious and generally unsuccessful he is always interfering in other people's affairs. He would show Crane how to make a fire and how he ought to hunt (8); he would go with the Geese whether they wanted him or not 
(13); he has something better to suggest to the fish as entertainment even though he does not mean his invitation seriously (12); as the moon he announces publicly every act of the people on earth whom he spies on at night (1).

Coyote has little originality but is essentially imitative. His imitation is usually unsuccessful as when he tries to fish like Magpie (14), when he imitates Crane (8), Grizzly (17b) or Woodtick (16).

$\mathrm{He}$ is dictatorial to all but Mole, his wife, bears the brunt of his orders. When she calls attention to his unreasonableness or lack of judgment, he snaps "Don't answer back! Do what I tell you!" (6). And she, contrary to her better judgment, does it, but she has her own power and quietly, stubbornly and conservatively outwits her despicable spouse.

In the ease with which his attention can be deflected Coyote is a regular monkey. He may set out with the most serious purpose only to be diverted by the slightest thing. When he is seeking revenge on Mrs. Badger, he forgets all about his errand watching the two Nit Children slapping each other (15). He is impatient of the training Little Beaver requires to get his power, but in this case his loneliness overcomes his laziness (5). He is not above cheating when he gambles, but he tells on others who cheat and he himself stops while he is winning.

There is no doubt that the Indians wish the total impression of Coyote to be bad, but there are some cases where his compassion is genuine and where his stupidity or his successful trickery is beneficial. His loneliness after his children have been killed by the Grizzly is a case of real feeling, "When he (Little Beaver) plays around my house I feel happy. Then I forget the loss of my own children. Then and then only can I laugh" (5). His blunder in feeding Cricket elk fat was prompted by kindness alone. The mistake was due to Coyote's stupidity in not knowing that all people are not meat-eaters (18).

Coyote's encounter with Gobbler was clever in every respect. He is credited with the origin of the Indian tribes and is responsible for their characteristics. The Coeur d'Alene came out well in this deal (2). Another case of his blundering on to a good for man was in releasing the salmon although even here he discriminated against those who refused to furnish him with a wife (8).

Above all Coyote is versatile. He is greedy, sly, impudent, impatient, impulsive, stupid, suspicious, ignorant, imitative, cruel, ungrateful, interfering, boastful, vain, clever, and rarely, compassionate. The Coeur d'Alene admire his slyness, fear his power and trickery, distrust his promises and even his success and, above all, despise him. Nevertheless they, like the mythical animals, are curious to see what he will do next (17). 
Not much is said in the tales about Mole, Coyote's wife, but she is a perfect foil for Coyote. She is as unostentatious as he is ubiquitous. We may picture her, a quiet, tight-lipped, determined little body industriously going about her affairs with sure skill and wisdom. Coyote is willing to rush into a situation impulsively. Mole calculates the results and acts in the most conservative way $(6,17)$. She loves her children and can usually do well by them, but when Coyote goes absolutely berserk she has no power to save her sons from death. By the exercise of careful strategy she saves her daughter, brings her sons to life and punishes Coyote (6). There is no blatant way of holding Coyote who is as promiscuous as he is undependable, but Mole resorts to subtlety. When she is at home she wears a gray dress but when she goes out to dig camas she wears bright red. The scarlet woman among those digging is sure to be Mole. Coyote complains when he sees her from a distanceshe becomes gray if he comes too near- "Just as soon as she leaves me she dresses up" (6).

A character frequently mentioned and definitely stereotyped is Grizzly. $\mathrm{He}$ is fierce, he bites and claws, he attacks with a growl and is rarely beaten. $\mathrm{He}$ is considered such a good fighter that his mode of attack has become symbolic of bravery $(5,9 b, 17,27)$. He is called Hammered Sitting Place because his posterior is flat from much lazy sitting. He is expert in feathering arrows. Therefore Catbird calls upon him for that purpose (22).

Another actor not thoroughly approved is Raven. He, like Coyote, acts without the chief's orders (19), he pecks out people's eyes (7) and is generally distrusted. His own eyes are white and turned back because he was choked by Lynx's wife when he tried to steal a ball of fat from her little son (9a).

Two excellent hunters are Lynx and Crane. In order to have hunting luck, one must have great power. Both of these animals have it and combine with it good qualities. Lynx is perhaps the best of the hunters. Even with two versions of the story about him it is not clear why he should have been punished as he was. The Story of Lynx is doubtless an example where several parts of a narrative were used without smooth articulation. He genuinely loves the chief's daughter and does everything as she wishes. He even sacrifices his looks for all time because she asks him to. His vanity is only for her as is his vengeance. We feel that he did not wish to punish the other animals like Coyote and Raven but did so only out of sympathy for her sufferings. He was willing too to accept the damages her father offered the first time, but left the decision to her and abided by it after she had made it $(9 a, b)$. 
Crane according to Coyote is not handsome. He has a raucous voice which Coyote cannot bear. He has excellent power, he can get much out of little, he is generous and long-suffering. Quietly, humorously and effectively he shows up Coyote's over-estimation of himself (8).

Catbird is a whining, pestiferous boy who always wants the impossible and gets it. He gets his will through slyness, determination and ingenuousness. For instance he tells Grizzly not to be afraid, he will not shoot him (22). He is considered unruly rather than admirable by the Coeur d'Alene.

The Wolves are thieves $(8,22)$.

Many of the characteristics of the animal actors are considered good or bad for people. Two characters are idealized. One of the squirrels, Saretcen, is the symbol of perfection. Whatever she makes is perfect and it is considered a great boon to have anything to do with her. She is also neat and pretty.

Toad is the symbol of self-sacrifice and fatality. She is ugly and always wets everything, but is extremely clever (1). She acknowledges her homeliness and is willing to take on the sufferings of others because after all what does it matter what happens to anyone so unattractive? "You are beautiful and young; I am old and ugly. I will die in your stead," is her stereotyped speech (31).

Rabbit and Jack Rabbit have human characteristics brought out satisfactorily by story 35 . Rabbit in other cases is dignified and clever (2). Bluebird was modest even about his beautiful coat of blue (9). Human failings, whether shown by human or animal actors, are realistically portrayed. Curiosity is so strong in the older sister of the Dog Husband story that she cannot stay away from her younger sister even if she is mistreated (11).

An analysis of the characters of the myths and their behavior gives a splendid clue to the qualities admired, discounted or despised by the Coeur d'Alene. Deceit is not condoned, but it is necessary to furnish conflict in the tales. If the end is gained it may be tolerated, but it is often punished. No explicit indication of approval or disapproval is given about cruelty. Coyote is punished, but not too severely, for devouring his children in the cruelest fashion (6). He is killed for his cruelty to the children of the pheasants. The cruelty of the boy who poked out the eyes of many individuals is punished by desertion, but he comes out rather well in the end (27). By and large the Coeur d'Alene are proud of their reputation for heartlessness. They were created from the heart of Gobbler and have consequently been "mean" ever since. They boast of their hardness and tell the tale with pride. It is perhaps equivalent in their minds to bravery. No shivers run down the back of 
narrator or audience at the gruesome description of the scalping of the Nez Perce chief (37), or even at the historical account of the Blackfoot warrior who was scalped and sent home (48). Pride in a dangerous exploit is the dominant emotion. There is scorn too at the mention of the tears running over the Blackfoot's face as he is being scalped.

The quality of mercy is not by any means absent but is manifested in special situations. Chief Child of the Root is a constant example of compassion (1). He helps the deserving, spares them from the results of their own stupidity, even though he punishes those unfavorable to man. His compassion for man is deeper than his pity for the ones he subdued. This character is identified with Christ.

The Geese brothers love their sister Squirrel, and when they go out singly to kill her, each returns saying he has not seen her. It is only when two of them go together that they fulfil their agreement to punish her (13). Rabbit and Magpie pity the girl deserted with her baby by her father and his whole village and bring back their blankets for the baby even though they have to deceive the chief (9). Coyote's son apologizes profusely for having killed Harvestman, the father of the Beaver girls. He would not have done it had he known and he brings the father to life again (4). Woodpecker for no apparent reason takes pity on Coyote and works two days pecking out his eyes from the rocks in which he is imprisoned (7). Several of the squirrels and some feathers help the man of tale 25 out of his difficulties, apparently because they pity him. It may be however that he had them as guardian spirits. There are as many illustrations of pity and compassion as there are of cruelty and heartlessness.

An attitude markedly conventionalized is that of hopelessness. A person starts out on an impossible quest. Everyone he meets attests the futility of his task, but each one offers also some piece of advice, perhaps even gives tangible aid. Along with the prediction of failure goes determination on the part of the seeker who continues until he wins $(17 \mathrm{~b}, 22,24,25,26,27)$. The conservative element of the population, the grandmother, the grandfather or Mole, the highly cautious character gives the warning. Their viewpoint is: Don't try anything new or unusual because there is no reason to suppose you will succeed but, if you will try it, here is something which will help. Do this, do that, use this aid which I can give you. If the project is a success in spite of dire prophecies, as it usually is, the greater is the honor of the achievement. The myths reflect the Coeur d'Alene attitude of fatality, but with it goes dogged determination and it is not unusual to find individuals actually succeeding in tasks which require long and persistent effort. 
Perhaps the most valued ethic among Indians is hospitality. It should be differentiated, I think, from generosity, which is not considered in the same way. It is almost impossible for an Indian to refuse anyone a meal. Even nowadays when food is not always plentiful, due more to improvidence than to actual poverty, there is a feeling of smallness and shame if guests cannot be fed. Catbird's grandmother deserted him because he was stingy with his fish (22). The ideal treatment of a guest is to urge him to eat all he possibly can, to spare nothing, then to take home what remains for, in a properly-run household much does remain $(2,8$, 9). Even when food is very scarce, the little is shared (1). The sympathy of the Coeur d'Alene is with the boy who took good food from his parents without permission because "one should not think more of food than of his children" (46). Fisher urged himself not to be stingy with the good food, even though Skunk's request for it was unusual (23). Deprecatory individuals ask for scraps (23).

Jealousy is frequently manifested, as is pride. Coyote's boastfulness and vanity were often due to jealousy. He was jealous of Mole and he did not understand her. She was conservative and cautious, he was impulsive and thoughtless. She had power and he had none. He was envious of hunting power possessed by Lynx $(9, \mathrm{~b})$ and Crane (8). Quiet manifestation of the qualities which make for success infuriated him. Fisher was jealous of any success his partner, Skunk, might have with the Squirrel girls. The older sister was violently scornful of her younger sister because the latter's husband was so ugly but, as soon as he became handsome, she wanted him for herself (23).

Pride, in the myths as well as in reality, is often expressed by silence. Splinter Leg is a good example of pride even in humble circumstances and is typical of other actors in the same story (1). "You find us humble. You honor a humble home" is polite acknowledgment of conditions which the host does not necessarily believe are modest. An appearance of humility or modesty is admired. Bluebird thought his coat, really the most beautiful of them all, too modest to offer as damages to the chief's daughter $(9 \mathrm{a}, \mathrm{b})$. The really great do not boast or brag of their power and exploits. That part they may leave to Coyote but, when occasion arises, they quietly and modestly use their influence and accomplish marvels.

\section{STYLISTIC DEVICES}

The specific character of a given myth-body is affected by a selection of details rather than by the more general use of episode, plot, motivation and the like. The same is true in plastic art. Principles upon which 
composition is based, elements used in composition or technique, may be of very wide distribution, but the selection of these various factors, their recombination and working out, these are the details which put feeling into the art and determine its style. We have already seen that Coeur d'Alene mythology gains much of its flavor through characterization. Even more striking effects are secured by linguistic and rhetorical devices, the first of which are inherent in the language, the second open to a wide range of choice.

Coeur d'Alene is a member of the Salish linguistic family, most of the dialects of which use duplication, reduplication or both as a morphological device. In Coeur d'Alene this feature is also highly developed and plays an important part in creating effects. Reduplication is used for expressing plurality, diminutive, continuative, iterative and distributive.

It is not difficult to understand how such a morphological device may affect the literary style in a marked degree, especially if the people using it play with it. Words themselves which are duplications, for instance, ritrit, xwr'u xwi'u, the names of birds, yapiyapen "man-eater," give a distinct character to sentences and the tale may gain much of its effect from the use of duplication. The story Cricket rides Coyote (20) owes its humor to the fact that combinations of comic sounds are repeated until the story becomes side-splitting. This is only one of many examples which shows how impossible it is to carry over the spirit of the tale into a language like English, which has no machinery for the expression of such an effect. Another tale which demonstrates the same device used to achieve a different result is that of Catbird (22). He was tiny and babyish, so all of his things and behavior must correspond. The only way we have of expressing diminutive is by adding "little." "Then this little bird hung up in a little way his little moccasins on a little hook." It sounds silly in English and at once becomes monotonous. There is no way, even ungracefully, to express diminution in a verb, and consequently our translation of this tale sounds like the rest. In the Coeur d'Alene rendering the diminutive element establishes a setting which is as rhetorical as it is linguistic. By this grammatical device alone a contrast between the smallness of Catbird and the bigness of Elk, Wolf and others is established which is purely literary. The enjoyment felt by the narrator and listeners is shown by the light in the eye and the expression on their faces and they will tell you "The story of Catbird is 'awful cute." "

Coeur d'Alene has a method of expressing subordination. The same particle is used for all sorts of dependent clauses whether adverbial, relative or participial, but it is not a favorite means of expression. "Cat- 
bird went to tell his grandmother that the Wolves had stolen his meat." The language has the machinery for the expression of this sentence, but the Coeur d'Alene prefers to say, "Catbird went. He went to his grandmother. He told her, 'The Wolves have stolen my meat.' "' The result is that instead of long periods there are short staccato sentences which express all that is necessary and primarily emphasize action. Continually there are quotes within quotes and this habit gives a definite character to the style which superficially looks like a language deficiency. Actually it is a choice of definite simplicity in preference to bluffing prolixity.

A third linguistic peculiarity is noticeable and pleasing even to those not understanding the language; to those who do understand it, it is a constant source of delight. It is a tendency to lengthen the vowel with a voice glide from high or very high to low to express "much," "many" and the like. $x w i s t$, "he went," but $x w i \cdots s t$ "far he went," and $x w i \cdots s t$, "very, very far he went." This device can be well expressed in English phonetically, but it cannot be easily expressed orthographically. "He is lazy," but "He is la $\cdots z y$." The former is a mere disinterested statement of a fact, the latter a special emphasis on the fact that he is too lazy to live, disgustingly lazy or something of the kind. Pitch accent is much used in Coeur d'Alene as in every language, but this is its only grammatical use. It takes the place of a superlative here, if we may say that there is a superlative in verbs. It adds zest to the narrative effect.

A number of rhetorical devices are used, not all corresponding exactly to our own. One of the most frequent is what I shall call "obscure simile." A continually occurring phrase in Dorothy's narratives is "He did it. He did like this." Then instead of saying what he did she acted it. She sometimes employed a simple gesture or performed a little act. There is no way of recording such a habit and in reading the tale the effect is totally lost. Feebly I indicate the gestures but despair of carrying over the life put into the tale. Gesture and action are commonly used by Indian narrators and perhaps nothing can be done to capture artificially what they add to the enjoyment of the myths. Tom, unlike Dorothy, completed the simile in words, although he sometimes accompanied them with acting. I was once astounded when he got up from his chair, went out the door, lay down on his stomach on the porch and worked his way in, crawling sneakingly as one would up to a tent in the dark. During all this pantomime he had been telling the story and when this scene was finished he returned to his chair and quietly continued.

The discussion of characterization shows to what extent personification is used. Besides attributing human behavior to animals the Coeur d'Alene assign it to natural phenomena as, for instance, to Thunder 
(25) whose power lay in his shirts or to Wind (21) who had long curly hair, big eyes and a wide mouth. Personification is so common and so apparent that a discussion of its use need not be prolonged.

Repetition is used universally in art and literature, but there are various ways in which it may be managed. Words, phrases, episodes or incidents may be repeated. The unit of repetition is different in various tribes. Among the Wailaki of Northern California, for example, the passage of time is shown by repetition. There is no hesitancy on the part of a narrator to reiterate the same phrase ad nauseam to show that his hero stayed at a place for a year. In some tribes the unit of repetition is nine, in others, five; a thought, act or phrase is repeated a stereotyped number of times. Among the Coeur d'Alene this unit is four. Persons or objects commonly come by fours; actions are repeated four times. Four helpers belong to Coyote, the man who lost his wife was given four needles and later four feathers to help him get to Thunder (25). Coyote had four sons; there were four mosquito brothers and one little one with strong power (28). The purification ceremony of sweating and bathing was carried out on four different days (41); Waterbird slept four days by mistake (26). Repetition is however not consistently fourfold; two is sometimes used. Dorothy usually, when not sure of the time elapsed, said, "Long, I don't know how long, I guess two days," showing that four was not dominant in her mind. Not seldom there were only two sons or two daughters in a family or at least only two are mentioned.

As a mode of plot development the use of thought or direction by a third party and the repetition of that thought or direction by the protagonist has been noted. These repetitions are given in direct discourse and illustrate how the same device may be used for plot development and as a stylistic element.

Perhaps the most outstanding aspect of repetition used by the Coeur d'Alene is the constant use of formal phrases. Major actors have characterizing sayings. Other sayings are stereotyped for given occasions. In a contest Coyote says, "It must be the child of my first-born" (9b). Coyote always uses "my daughter's child," for "my son's child" (9b). $\mathrm{His}$ inability to get the kin-terms correct illustrates his stupidity. $\mathrm{He}$ says when importuning his powers, "My power relatives, you give a person the chills." Another of his nonsensical but nevertheless functional speeches is, "My father's father's father knew that trick, too" (8, 18 ), or "My father and his father and his father had that name for their dogs" (2), thus adding time and tradition to the weight of his boast. When Wolf or Thunder or someone with much power is thwarted, he says, "There is no place on earth I do not know" $(22,23,24,25)$. It 
is equivalent to saying, "There is no place on earth where he can hide from me. I will surely find him," and the actor thereby indicates his intention to make a thorough search.

Catbird's grandmother always reacted to his proposals with a phrase meaning "Impossible! Scandalous even to think of it!" This phrase is typical of Coeur d'Alene conservatives and other characters use astonished words of warning which have essentially the same meaning. Two formal greetings signifying welcome as well as expressed modesty are, "You honor our humble home" (1) and at meal time, "We are pitiable. We are poor. We have nothing to eat. We would have more had we expected such an honorable guest, but you are welcome to the little we have." "We are pitiable" is a common expression to gain sympathy for many causes, for instance, when begging for mercy, when pointing out a bad circumstance or offering sympathy, when announcing disaster $(1,2,4,6,7,18,21,22,25)$.

A formal turn of phrase often used is dependent on a Coeur d'Alene verb stem, "No longer are you (or is he) a decent person." The stem signifies, "decent, refined, cultivated, adaptable, trained, well-behaved." Perhaps "civilized" would be a good translation. The son of Dentalium Girl was "no longer a real person" after growing up with the man-eating women (24). A woman stolen by Thunder was no longer a "decent person" (25); the wife of Waterbird degenerated from living with the Snakes, people who were not of her kind.

There are other sayings commonly used but not often repeated in the myths. "There is a hole in his moccasin near the big toe," is a "mean" expression used by a person who is jealous to indicate "He is longing for some other woman" (4). When something important is about to happen, people may say, "Beaver's older sister is going upstream, Beaver's younger sister is going downstream."

The introduction and conclusion of narratives are usually formal. The most common introductions have been noted. The ordinary conclusion is a variation on the theme "I have come to the end of the trail." (This may be a false etymology as the natives do not translate the word.) This is sometimes extended into the ending "the little bird sat on a tree at the end of the road and was shot."

Actors are recognized by the sounds they make which constitute a characterizing device. It is not proper in my opinion to call this use of sound onomatopeia, because the sounds have no meaning apart from the characters who use them, nor do the Coeur d'Alene feel that they are the noises which the given animals necessarily make, although this may occasionally be the case. The abundant use of sounds is one of the most striking factors of Coeur d'Alene style. 
Most people snore $x u x u$ (Thunder [25], the Nez Percé [43]) but Coyote asleep makes the sound xzen xzen (13). This conforms to his habit of distorting and exaggerating.

There are many of these sounds but a short list will suffice for illustration:

$\begin{array}{ll}\text { p'ap'aq' } & \text { a "bad-sounding" noise made by Skunk (23) } \\ \text { tcisasat'at' } & \text { a "nice" noise made ordinarily by Fisher (23) } \\ \text { olu'lu'lu' } & \text { noise made by Fisher when he dives (1) } \\ \text { tsalala } & \text { noise made by Kingfisher diving (1) } \\ \text { ona'na'na'n } & \text { noise made by Magpie's children eating (9) } \\ \text { ots'ats'at } & \text { noise made by Rabbit's children eating (9) } \\ \text { patatsat } & \text { noise made by Chipmunk hopping (25) } \\ \text { natnata } & \text { noise made by another squirrel hopping (25) } \\ \text { mu mu } m u & \text { noise made by bones being transformed to dentalia (24) } \\ \text { t'a t'a t'a } & \text { Cricket's sound (18) } \\ \text { oyurayura } & \text { Grizzly's sound (5) } \\ \text { quar qrear } & \text { Crane's sound (very disagreeable sounding to Coyote) (8) } \\ \text { otcar tcar } & \text { Raven's sound (9) } \\ \text { op'axp'axp'ax } & \text { sound made by Snowshoes on snow (33) } \\ \text { opampam } & \text { noise of bow (27) } \\ \text { opatsatsa } & \text { sound of Snake's stick hitting Chipmunk (32) } \\ \text { ola'u ola'u } & \text { sound of "pans" in Coyote's ear (6) } \\ \text { xuts xuts } x u t s & \text { sound of bone breaking (sounds "awful") (31) } \\ \text { otsaxtsax } & \text { sound of teeth grinding (38) } \\ \text { ludidi ludidi } & \text { sound of spiders spinning (4) }\end{array}$

The use of sounds is not restricted to noises but they may even express feeling:

änininin
änimim
älilili
tsaskäninin
halalas

pain felt by Meadowlark when her leg bones have been broken feeling of pain when Splinter Leg carves his own leg bone (1) feeling of cold water on the body (22) feeling of Catbird passing through Elk's nose (22) phrase with which Mole introduces herself (6)

Since feelings as well as noises are expressed by sounds and since there are verb stems of an entirely different nature which might in themselves be considered onomatopoeic, this wide use of sounds seems to be onomatopoeia at least in exactly our sense of the word.

Another important element of the myth-body may be stressed in an analysis of this kind but lends nothing to the myths in free translation because it must be garbled or omitted ; that is, the use of song. Characters have their special songs which are a part of the narrative, but frequently they consist of meaningless syllables or incomprehensible words. If the words have a meaning it is often given in a language 
other than Coeur d'Alene. The fact that another language is used adds an elusive element of humor to the tale which cannot be caught even in the best translation. The song of Catbird which, by changing a short syllable of each of two words changes the entire connotation of the sentence, loses most of its point when translated. The original gives the notion of contrast between Catbird's smallness and cleverness and Wolf's bulk and trickiness. The best I can do is to call attention to the fact that song is much favored by the Coeur d'Alene as a part of their tales, that it is a characterizing factor and that it is frequently expressed in a language which is not Coeur d'Alene $(1,8,12,18,22,30)$.

The most common modes of making an appeal are by humor, pathos, bathos, macabre and sarcasm. A question frequently asked of an anthropologist by those not acquainted with Indians is, "Do they have any sense of humor?" Of the Indians I have met in the course of twenty years of fieldwork, I recall only one who had no sense of humor, as large a proportion, I suspect, as among our own population. I have the impression that the Coeur d'Alene are especially gifted in this respect. I speak now of individuals who show great wit and whimsicality, as well as of development of humor in the tales. Perhaps I should say that this feature of their literature has been especially cultivated.

It is frequently noted that humor among Indians is obscene. This type is by no means lacking among the Coeur d'Alene $(1,5,7,8,23)$ and it is duly enjoyed, but they do not by any means depend upon obscenity to furnish comedy. Humor is primarily of two kinds, that of language and that of situation. The Coeur d'Alene play with words delightfully. Puns are used $(7,22)$ but they are more numerous in conversation than in myth. The use of foreign phrases transforms a tale from ordinary to riotous. The inclusion of a Spokan or Flathead sentence, either of which sounds like bad Coeur d'Alene, sometimes gives rise to uncontrollable laughter.

Phrases from unrelated languages like Nez Percé are also much enjoyed. The element of incorrectness seems to be comic, for Coeur d'Alene words mispronounced are equally hilarious. Coyote was the greatest linguistic clown. He always said, "gr-gr-gr-father" for "grandfather"; histomc for hisctomc "my friend," to Fox; "my daughter's child" for "my son's child."

Of importance equal to play with language is the humor of situation. Coyote most often is the butt of the jest, but he sometimes has a chance to laugh at others. Coyote displaying his vanity by wearing Nighthawk's coat, could not stay on the ground but kept jerking upward the way Nighthawk flies (19). The ruse Bullfrog played on the people to see Chief Child of the Root is amusing for its cleverness. No one of the 
crowd would move aside so she could see him. When she requested them to move, they asked why such an ugly thing wanted to see. Because she quietly sent a rain so heavy that no place but hers was dry enough for a fire, the Chief came to her house and she was able to take a good look at him (1).

The whole story of Cricket riding Coyote (20) is comic because, in addition to the situation, there is constant use of reduplicated stems even ordinarily composed of amusing combinations of consonants. Crane was accustomed to hang a deer on each side of his belt because he had power to put "much in little." Coyote's great grandfather also knew the trick, he said, so he also tried it. One can enjoy his discomfiture when, although he had only two fawns as his kill, he staggered along with them constantly becoming heavier and dragging him down. Besides impeding his progress, the weight tore at his belt and he was constantly hitching up his load (8). Those who appreciate the mimicry of the toothless aged will enjoy the scene where Coyote refuses food-the very fact of Coyote's refusing food is comic-because he has no teeth. He lies snoring with his mouth open and his toothlessness of which he is ashamed is exposed to Pine Squirrel, the person he wants most to impress (13).

When Dentalium Girl selected a husband, Mudhen wanted her to choose Redheaded Woodpecker, her grandson. When it looked as if she were going to pass him by Mudhen pushed him forward, pushed him, so to speak, into the arms of the girl (24).

In contrast to humor pathos makes a strong appeal. Desertion always gives rise to pathetic situations, the details of which are handled effectively. Lonesomeness is frequently stressed. Coyote's grief at the loss of his sons, in this case genuine, his struggle to keep little Beaver and the resultant reward are vividly portrayed in the story of Little Beaver (5). The utter hopelessness of the deserted is a Coeur d'Alene convention. To me the most moving tale of all is the story of the mother whose baby son was kidnapped and her struggle to get him back. After journeying for years from her own home to that of the man-eaters who had stolen him, she was obliged to prove that he belonged to her. $\mathrm{He}$ had in this time grown to manhood and was "not decent" because of his environment. Against time and bad training as well as against man-eating power she must exert her will. Even after she broke down her son's mental resistance, she had to demonstrate by physical means her right to the title of "mother." After she had freed him from his bondage to the man-eaters she did not try to chain him to her but, even though it grieved her almost as much as his sojourn with the evil women who stole him, she left him to his element, water, while she sought hers, the forest (24). 
Lonesomeness in life as in myth is tragic to the Coeur d'Alene. The same causes give rise to loneliness as among ourselves, desertion, death and separation $(4,24)$. A common phrase in life is, "Poor thing! She is pitiable. She has no one. Her daughter died. Her sons are away. She is all alone."

Pathos sometimes gets in its full appeal and then relaxes. Coyote's cry of despair arouses undue sympathy until it is learned that he has left his spittle to cry for him while he is playing a trick (4). When the chief and his people were starving after leaving Lynx and his wife they heard peculiar noises from the home of Magpie and Rabbit who lived together. "Go help them if you can. Perhaps the poor things are dying," ordered the chief. The messengers reported that they were so hungry they were eating moss. The fact was that with one side of the mouth they were eating strips of grease which Lynx had given them and from the other side moss hung down to fool peepers, so that the sympathy was wasted $(9 \mathrm{a}, \mathrm{b})$.

The discussion of cruelty gives some idea of the use of macabre. Once more Coyote is the protagonist for he stops at nothing, be it humorous, pathetic or gruesome. Coyote not only killed his neighbor, Deer, but tortured him before he died. Coyote's arguments with Mole who, through pity tried to help Deer, add humor to the situation. This story continues to show Coyote in his worst light, for he not only destroyed the whole Deer family, but he cruelly killed his own sons also and was about to devour his little daughter when thwarted by Mole (6).

The account of the adventure during which Coyote loses his eyes is gruesome in the extreme. The deceit he used with the Pheasant children and the terrible condition he left them in is the extreme of cold-bloodedness. There is however even in this episode an element of wit. The conception of Eye Juggling (7) is not an appealing one, yet the episode illustrates a use of a kind of humor much more widespread than the Coeur d'Alene area.

One of the best defences the Coeur d'Alene has against his present social environment is satire. $\mathrm{He}$ is proud. Even before the coming of the Whites he admired some of his neighbors and despised others. These attitudes were expressed indirectly by satiric remarks. It is no wonder then that he turns this weapon against the intruders in his country. The way in which the story of Little Beaver (5) is interpreted nowadays is interesting. The Grizzly is thought of as Washington, that is, the U. S. Government, the hard food is the humiliation constantly borne by the Indians and the gradual encroachment upon their lands and rights, the interpreters are traitor Coyotes. The Spokan, with whom the Coeur d'Alene were usually at peace, come in for a dig when Coyote creates the 
tribes. He was all finished with cutting up Gobbler and throwing about pieces which finally became the various tribes. Then he looked at his hands, noticed they were bloody and wiped them on some grass. He threw the grass away and the blood on it became the Spokan. "That is the reason they have always been so poor."

There is no great opportunity for comparing individual styles of the Coeur d'Alene, since there were only three informants. There are however two narratives told by each of the two informants who knew myths and the style of the historical narratives may also be compared. A brief description of my two main informants will account for the difference in the style of their versions as it is primarily a matter of temperament.

Dorothy Nicodemus was the widow of Nicodemus who gave Teit most of the material in his Coeur d'Alene ethnology. Nicodemus died many years ago. Dorothy was an eager and interested student of his lore, she had a good memory and took great pride in her knowledge. She was over seventy at the time the tales were recorded and her own experiences alone provided much of interest. Some of them were bitter, but she had a kindly temperament and a sweet disposition. As a result she was frequently exploited. During the last few years she gradually became totally blind and was consequently quite dependent upon others. She managed however to catch muskrats in her brook, to cook for herself and for her sons and grandson when they were home and to perform other necessary tasks. She enjoyed company and loved to tell stories. All the acts of the tales were graphic and alive to her and by intonation and gesture she added much to the intrinsic nature of the style. I have mentioned before her habit-a bad one from our point of view-of using "like this he did," the simile depending upon gesture and act rather than upon words. She preferred to retain old forms in her tales and almost never consciously brought in modernities. She could explain some phrases only by saying, "It belongs to the story." She was just as conservative in her outlook on life. Spiritually she belonged to the days when the Coeur d'Alene possessed and used the rivers, lakes, forests and prairies as fishing, hunting and digging grounds. Her style reflected this attitude and nothing materially or even intangibly modern changed it. Her humor was quiet but copious. She appreciated a joke with the best and she had many at her tongue's end.

Tom Miyal was a nice contrast to Dorothy. His humor was active and continuous. Everyone expected a joke from Tom, even if he was seen for only a moment on the street or in passing. In a gathering a running stream of wisecracks was expected from him. He was invariably goodtempered and it was said that he could always be depended upon to make fair judgments. Some of these characteristics were reflected in 
his versions of the myths. Wit is the outstanding difference between his and Dorothy's. Hers are humorous, whimsical; his, sparkling, ridiculous. One way in which he attained his effects is through the use of modern elements. He has the Land People "phone" upriver to make a trap for Snake (10). His vocabulary, which can be ascertained only by a detailed comparison of the texts, differs considerably from Dorothy's, and he was able by changing tone and accent, to make the use of foreign phrases even funnier than they ordinarily sounded.

The recorded texts do not do justice to his style. He was primarily concerned with movement, with action, with the development of the myth. He had no conception of the slowness of some white recorders and often had to be slowed down. Consequently some of his phrases are lost.

A summary of the means by which the Coeur d'Alene achieve effects, when compared with other literary styles, shows some noticeable negatives. In comparison with the Thompson tales, for instance, extreme localization as a stylistic factor is absent. Every Coeur d'Alene narrative has its local setting even if it is not mentioned in the tale, but in only one case is it used to explain the appearance of natural phenomena as they exist today. When Coyote went to the Coeur d'Alene after securing the salmon he made a little dam in the lake where he hid them. The rocks can now be seen on Lake Coeur d'Alene, showing where Coyote set up his sticks (8). Even without Thompson texts, this type of treatment is striking ${ }^{1}$ and just as remarkable is its absence from Coeur d'Alene tales.

Several other conventionalizations, marked in other styles, are not used in Coeur d'Alene; namely, color and poetic allusions to natural phenomena like clouds, mists, mountains or stars. True, Thunderthunder and lightning are identical-is an actor, and an important one, and mountains are used as settings, as are rivers and lakes, but throughout the myth-body these elements are utilitarian and objective rather than a matter of adornment. A comparison with other styles will make clear this lack. The Navajo myth is inconceivable without the stress laid on color, on rain streamers, rainbows, sky curtains and sunbeams. It is difficult to think of Pawnee mythology without starlore, of Hawaiian literature without a curtain of mist. Mole in her red dress is the only dash of color in the grayness of the Coeur d'Alene camas flat. There are a few Coeur d'Alene tales which end with transformations into stars, but they are, like Thunder, Cold and Heat, a matter of fact and not of poetry. Contacts between Earth People and Sky People are not numerous and the few there are contain no speculative imagery.

${ }^{1}$ MAFLS 11. 
The body of Coeur d'Alene mythology which has been examined in minute detail is small but demonstrates clearly the conventionalizations which compose the style. Plots and motivations are not unique but are those used in a large part of North America. Several episodes are characteristic of Coeur d'Alene and the unification of episodes shows certain peculiarities. The characterizations and stylistic devices, both linguistic and rhetorical, are of greatest importance in achieving effects. Of these those which contribute the most, cannot be adequately rendered in English: reduplication, vowel lengthening, sound, song and gesture. Such unfamiliar devices are capable of adding greatly to the total effect.

The essential impression is that of action. Coeur d'Alene stories never drag; they move and frequently they move fast. The action is staccato in effect. The emphasis on situation is strong and there is a keen psychological understanding of human nature. There have been numerous examples of tolerance and understanding of human foibles, and the brief historical tale illustrates them further. The Boy of My Story (42) could hardly have been in a more dangerous position than when his camp was attacked by the enemy. At a warning from his mother he had jumped up out of a sound sleep and started to run with her. Suddenly he bethought himself of the new little suit his mother had made for him to wear after his quest for a vision. The securing of the suit became more important to him at the moment than life itself. He ran back for it and, in the split second it took to grasp it from under his pillow, his eye caught the prone form of his father. His mind was on his suit, his eye on his father, at the moment when a shot came from the enemy. In that instant he retained the presence of mind to fall flat on the ground. Thus the story catches the swift essential points of a dramatic moment. The Coeur d'Alene language is peculiarly fitted to portray them adequately. An outstanding characteristic of the narratives is vividness, which is achieved primarily because the Coeur d'Alene have a sense for the dramatic, embellish it with humor and traditionally select linguistic and rhetorical elements. 


\section{Cultural Reflections in Coeur d'Alene Mythology}

In addition to stressing the style of the tales I take occasion to point out the more unusual reflections of culture in them whether they are implicit or explicit. Such hints have particular value in the case of a culture like this one since details from other sources are so incomplete. The facts are avowedly fragmentary but some corroborate, a few contradict and others add to, our knowledge of the life as described by Teit (ARBAE $45: 23-396$ ).

Material culture and economic life. The general pattern of the material culture is quite well known since it differs little from that of the Salish and northern Plateau neighbors, the Flathead, Okanagan, and Nez Percé, for example. However there are a few interesting differences. The myths most often mention only the general features of material and economic life, taking for granted perhaps that everyone knows the details.

Points were fastened to arrowshafts with pitch. Little Beaver's mother split the toe next to the small one so he could catch a coal to melt pitch for fastening his arrow as he stumbled through the fire at Grizzly Bear's home (5). It was the custom to fix the arrows just before using them, for Little Beaver carried his points in his hair and, after securing a coal, sat down and attached them to the shafts. Coyote prepared his arrow and set it to dry when he contemplated killing Deer (6). In the myths feathers of half-grown eagles were used for arrows. Grizzly was the expert arrow featherer (22). Curiously enough Teit does not mention eagle feathers for arrows but only those of hawk and grouse (ARBAE 45 :99).

Teit (ARBAE $45: 97$ ) has not identified the bowwood but it is probably yew. This wood was used by Catbird for his bow (22).

The use of grass thread is mentioned, but there are no details as to its character ( 4 ; and cp. ARBAE $45: 47$ ).

Coyote gathered cedar bark for a bucket which he made on the spot for immediate use (6). A bucket, not further described, was one of Coyote's favorite utensils. He tried to kill badger because one of her children took it from the house (15).

Constant references are made to the house of mats but there is no description of them in the myths. They seem to refer to the conical mat 
lodge described by Teit (ARBAE 45:58). In tale 4 Black Swan, Coyote's daughter-in-law, was probably carrying the mats. There was some kind of a vestibule, not adequately described by the informants, where things were stored. This seems to be referred to in tale 23, when Skunk offered food to the Squirrel girls. There was some discussion, not definitely agreed upon, as to whether the Squirrel girls were hidden in this place or under Skunk's and Fisher's beds. Small personal objects were hidden under the mats which served as beds and pillows and even today the Coeur d'Alene keep their most cherished small articles among the bed-clothing or under mattress or pillow. Turtle, after scalping the Nez Percé chief, hid under his pillow (37). One type of revenge was to burn the house of an enemy $(1,22,37)$.

One of the rush mats served as a door curtain. "To peep into a house" is really "to crawl up to the house and pull aside the curtain" (3). When the chief's two daughters came to Crane's house, hungry as they were for meat, they saw a door curtain ornamented with cooked camas (8). It is interesting to observe the difference in the attitude of these two girls surfeited with a vegetable diet and longing for meat and that of Hansel and Gretel when they came to the house made of sugar. European luxury was lost on the Coeur d'Alene girls. The description of Raven's entrance into the house (9) shows it to have been a long house. He flew through the crack left open for smoke, entering at one end, then along the ridge at the top of the house and between the poles at the opposite end.

Punk was used. Fisher put a piece in the fire, and during the night every time Skunk tried to visit the hidden Squirrel girls, Fisher kicked the rotten $\log$ and the house was lighted so that Skunk was ashamed (23).

The woven bag is a characteristic Plateau element. It is mentioned as a matter of fact. Cricket kept his belongings in one (20). Among them was a quantity of sinew thread which Coyote ate as soon as he found it (cp. ARBAE $45: 46$ ). The Spiders (4) had control of the thread supply and were the ideal weavers. Woodtick wove bags of Indian hemp as a pastime (16).

Dentalium Girl and her husband, Redheaded Woodpecker, had a baby. They made for it an ideal cradle board. The background of the ornamentation was solid white with dentalia and it was dotted here and there with tufts of the father's red head feathers (24).

There are two references to magpie-skin blankets or robes but they seem to be poetical allusions. Magpie and Rabbit each returned from their journey offering their blankets to Lynx's child (9). Each of them offered of course the only thing he had and it could not well have been a deer or buffalo robe. The cruel boy of tale 27 poked out the eyes of 
ten magpies, skinned them, dried the skins and made himself a robe. Quite probably these are cases of exaggeration and do not reflect actual conditions.

According to Teit (ARBAE 45:82) ear pendants were made of various shells. Nighthawk overcame the vengeful Rolling Rock by shattering it (19). Coyote suggested that the bits be used for ear ornaments. The informants knew in only the vaguest way of ear ornaments made of beautiful stone.

The foods mentioned in the tales show considerable variety. The food of animals is usually what they eat nowadays. The chief Coeur d'Alene foods were the flesh of animals, fish and vegetable products of which roots, especially camas, were the most important. Many references are made to camas as well as to camas gathering. Differentiation is always made between raw and cooked camas, and camas cooked with blood $(6,28)$. The oven in which camas, wild onions and other roots and vegetables are cooked for three days is referred to in tale 7 , although here the oven is used for cooking children instead. The brief description corresponds with that given by Teit (ARBAE $45: 92$ ).

In 1929 several of the old women still gathered the old foods and baked them for a winter treat. Everyone in the tribe gets hungry for them but few are willing to go to the trouble necessary.

Susan Antelope who was over eighty was famous for her camas. She spent at least three weeks digging camas and wild onions and gathering the black moss (Alectoria) which are much prized. When she was finished she spread them neatly on the floor of the barn to dry and they were a lovely sight, the camas a silvery white and the onions a purplish pink.

After these things had been gathered Mrs. Antelope spent several days collecting big chunks of wood for her fire and pine bark which was used for the covering next to the last layer of earth. When she was nearly ready to construct her oven, she travelled a long distance to a place where a particular broad fleshy leaf was found. This leaf gives the final excellent quality to the cooked camas. Everything was now ready for the building of the structure. The entire family, mother, daughter and two grandsons, worked for three days from early morning (about sunrise) until dark cleaning, that is, skinning, the camas and onions. After all were cleaned they were packed in burlap sacks, each kind by itself.

A pit about three feet deep was dug in which a fire was built and kept very hot for several hours in order to heat the rocks which had been placed on the bottom of the pit. Then the work of constructing the oven was begun. Mrs. Antelope's grandson helped her with this part of the work. The coals were left in the pit and the wood embers were shovelled out. Then the workers arranged grass on top of the coals, on the layer of grass the sacks full of food, then the large fleshy leaves. The steam emitted from the whole thing when these leaves were put on smelt slightly sweet and very savory. Next came the bark and finally, earth covered the 
entire structure. The burning brands were now placed against a circular fortification of wood chunks and the fire was kept burning energetically. On the day chosen for the baking there was a strong wind and nice judgment was required to keep the fire sufficiently active to bake and at the same time to control the blaze so it would not become dangerously hot. The result was an error on the side of caution and Mrs. Antelope was much disappointed, two days later, upon cautiously sampling her camas to find it was not done. They thereupon gathered old fence rails and other fuel and in half a day more she was satisfied.

It has been my purpose by this lengthy and somewhat personal description to give an idea of the amount of labor and patience involved in the preparation of this food. It should be remembered however that "bakings" of this sort are not made often, for at each one a large amount of food is prepared. Furthermore in the old days it was not necessary to travel so far or to search so diligently in order to gather the many specific things needed. Nevertheless even under the best circumstances the amount of labor required was considerable, if we were to count only the cleaning of the roots and the construction of the oven.

It is not difficult to understand the satisfaction the Indians take in a job of this kind well done, but it is not easy to describe. The word went out when Mrs. Antelope's camas was finished. She made a special point of sending some to her many friends. Others were especially invited to the house. They all get hungry for the old food and Mrs. Antelope had the reputation of making it the best. The "best" taste is due to the use of the fleshy leaves. Most of the old women, even Susan's best friend who helped her dig the roots, sprinkle sugar over their camas while baking it. It improves the taste but is not "quite as good" as that secured by steaming with the leaves.

After this digression let us turn once more to the consideration of food used in the myths. Several roots are mentioned besides camas. The root father of the Transformer (1), had a yellow flower somewhat like a sunflower but smaller. This was probably hogfennel (Peucedanum officinale). It was not eaten by the Coeur d'Alene-perhaps that is why it was a disgrace to have it as a father-but was baked by the Spokan. The second wife of Dorothy's father was a Spokan who often prepared it. Dorothy tried to eat it but it was too strong for her. She was sorry she could not eat it because it was very nice-looking. When baked it split open and looked like a very ripe apple.

There was a root (masmen) which had a bad odor and became black after cooking. It did not taste bad though and was liked by many. Coyote, in releasing the salmon, scared them away from certain places by telling them the rivers had masmas roots (8). This food arouses 
gustatory emotions comparable to those produced by Limburger cheese or sauerkraut.

Another vegetable food mentioned is the serviceberry $(8,14,44)$. Coyote said the women could gather them in winter and enticed them to the serviceberry flats only to disappoint them in the end.

References show equal stress on vegetable and animal food. The quest for game is naturally a common element of plot or motivation. Most parts of the animal were used. Deer lights were hanging in quantities outside of Lynx's home (9), blood was kept in the paunch of the deer (28), Coyote gave his daughter the head of the goose as a delicacy (6). The entrails and the fat and meat toward the tail of the animal were considered inferior. These were the parts modestly requested by Skunk before the advent of the Squirrel girls. (23). It is said that "scraps" were usually given children. The boy of tale 46 got tired of them and cut himself a piece of good meat without asking. These scraps were probably somewhat like those which constituted Skunk's daily diet.

Hard times were in sight when there was nothing but blood to eat $(6,24)$. The fact that nothing but a fawn was secured in a hunt is symbolic of scarcity $(8,9)$. There were many evidences of plenty at Lynx's (9), Woodtick's (16) and Crane's (18) homes, as well as at the dance house Coyote visited $(7)$ and in other places. Deer lights, bladders containing fat (7), rabbit skins (1) and meat hanging to dry gave such evidence. The Coeur d'Alene ideal was that after all guests ate until they were surfeited much should be left for them to take home. A parent would not eat all he wanted without reserving some for his children. If there did not seem to be enough he would surreptitiously tuck some away (9). Grease was appreciated for various purposes.

Strips of dried fat were a great delicacy. This food was given to Magpie and Rabbit by Lynx, a delicate compliment by which he expressed his gratitude for their aid to his wife (9). The girls who visited Crane were urged to eat all they wished when they quietly discussed keeping out some fat to be used as "cold cream" for their hands, as Crane promised they should take plenty along home (8). Coyote got into trouble because of his liking for fat. He was given fat as medicine with the injunction not to look at it, disobeyed and ate it, thus becoming blind a second time. He snapped at the bladders full of fat hanging from the roof of the dance house and they became rocks which covered him (7). The disk which Sun possessed and which the Coyotes and Antelopes struggled for is described as a disk of tallow (3), as is the toy Lynx's little boy played with (9). Grizzly was attracted by the fat in the trap which was one of Coyote's powers (5). In spite of his un- 
usual greediness for fat Coyote complained bitterly when he got nothing but bones and fat in the house supplied by Lynx (9).

Marrow was eaten and Coyote was voracious enough to be tempted by his own marrow ( 7$)$.

Peculiarities in food habits are as follows: Coyote bragged of his children eating rosehips (3). When Coyote was at the end of his string he ate two mice (2). References to such straits are considered very funny and do not seem to have any connection with the fact that the mice were his aunties. Cricket ate grass and was killed by Coyote's kindness in forcing him to eat rich fat (18). Deer ate earth (6) perhaps for its salt, a habit which Coyote could not understand. Grizzly, the man-catcher, gave his guests something so hard that only a trained person could eat it. This was doubtless something supernatural (5).

Numerous references are made to fishing $(1,47)$ but there is nothing specific or unusual about it except where it is avowedly mysterious (22, $27)$. There are brief allusions to fishing by torchlight $(10,27$; cp. ARBAE 45 :106).

Several methods of hunting are partially described in the myths. One, that of driving the deer toward scorched pieces of skin, was used by Crane (8). The description is not very full but, as given by Teit (ARBAE $45: 102$ ), is quite satisfactory. The other is hunting by means of a so-called fire corral. A fire ring was built around a large tract so as to call the animals to run toward the center where the hunters waited $(12,40)$. It was a method of hunting not generally esteemed because of its danger (40; cp. ARBAE $45: 102$ ).

The myths carefully enjoin hunters to take not more than two deer apiece $(8,13)$. Coyote disobeyed the leader's orders and came off with merely a fawn. Teit does not mention any limit to the number of animals which could be captured. More commonly when any kind of drive was undertaken all game within the area was taken (ARBAE $45: 101 \mathrm{ff}$.). The mythological limitation is quite in line with Coeur d'Alene conservation principles but, if too much game was secured at one time, it is quite likely none was wasted but the surplus was dried and kept for future use.

Cricket secured an elk by scaring him over a cliff; Catbird by crawling into the elk's stomach and killing him (22). In both cases the animal was butchered and the meat smoked on the spot. To skin the larger animals a cut was made around the nose and one from nose to tail anteriorly (13). Doubtless the meat of large animals was often smoked before it was taken home $(4,22)$. In the story of Calling the Deer (16) some of the cuts of meat are vaguely mentioned.

Teit mentions (ARBAE $45: 96$ ) the snaring of small game. Ermine was trapped especially for its pelt which is much prized for decoration. 
The Ugly Husband was able to snare this cagey animal when all the others failed (11).

Altogether if we depended upon mythology for our knowledge of Coeur d'Alene material culture we should have only a vague and unsatisfactory picture, for details are rarely mentioned and frequently the things most obvious to the Coeur d'Alene are merely alluded to.

There were many ways of dressing the hair (ARBAE $45: 83$ ). The description of the way Little Beaver's mother dressed his hair to show he was grown up is not detailed enough to match exactly any of the twenty styles described by Teit. She combed the hair, braided it and folded it up behind, tied it and stuck the arrowpoints in it (5). Foreigners were recognized by the way their hair was combed. The woman captured by an enemy had had her hair combed differently and smeared with red paint immediately after capture for, when she returned home after an almost miraculous escape, the first remark of her friends and relatives was, "Who combed you that way?" (44).

The custom of combing the hair of a spouse or child as a mark of intimacy was the rule (11) among the Coeur d'Alene as among most Indians. Delousing was also considered a sign of affection. Coyote, hypocrite that he was, used it as a ruse to entice his sons to their death (6).

Social Customs. Our notion of the spiritual side of Coeur d'Alene culture would be as sketchy as that of the material if we had only myths. There are nevertheless a few additions which may be made to the data already collected, but far more important is the understanding we may get of the attitudes of the people toward these customs. These may be learned only by witnessing the behavior of the people or by a study of their criticism of it as expressed in the narratives.

The organization of the tribe was territorial (ARBAE $45: 150$ ). Each village or band had certain lands which they considered themselves privileged to use. A few families forming a band or village group occupied a special territory. No one from another place could hunt or fish there safely without permission. Trespass was resented. This was the offense which got Muskrat into trouble with the Otter boys (30).

The territorial unit is what is constantly referred to by the introduction of the tales, "There was village. There was a chief," or "There were houses, many houses." The position of the home of the actors is always thought of with respect to the position of the chief's (Bald Eagle's) house.

The method of obtaining a husband for a girl most frequently mentioned in the narratives was to send her to a chief as a kind of offering. This was sometimes done by a poor man who wished to benefit his 
daughters $(8,23,41)$. Teit remarks (ARBAE $45: 170)$ that the honored or wealthy man might refuse to take the girl for his wife but he rarely did. The impression derived from the tales is that the man felt honored and was glad to have the girls who were sent. For instance, Chief Waxane went to the trouble of destroying the entire family of a man who, under false pretenses, took the girl sent to him by the chief of another tribe (41). To judge by the way in which this custom was regarded in story and in fact there is no reason to believe that the custom was abused. It is likely that a single refusal would cause families to consider the matter most carefully in the future and would thus for a long time restrict the proposal on the part of the girl's family.

An example of marriage by touching is that where Coyote was pushed by the Geese brothers from one bed to another until he touched their sister and by so touching her became her husband (cp. MAM 2:324). Dentalium Girl was allowed to choose her husband directly but was influenced by Mudhen, the grandmother of Redheaded Woodpecker, who had intercepted her on the way to the gathering (24: cp. ARBAE $45: 170)$.

Teit does not mention the practice of polygamy which was allowable, even common. Usually there were not more than two wives. A chief sent two of his daughters to Crane who married both (8). Two of the Squirrel girls were sent to Fisher and were coveted by Skunk but, after a struggle, were taken as wives by Fisher (23). Coyote's son had two wives on earth, Black Swan and Tern, and in the Sky country he married several Beaver girls (4).

According to Teit the girl's family gave gifts to the man's only when they were sent to the man as in the form of marriage described just above. Usually the man's family gave gifts to the other side. "As far as remembered," writes Teit (ARBAE $45: 170$ ), "there was no conveyance ceremony whereby the bride was conducted back to her people and presents interchanged." Although there is no evidence that it was a conveyance ceremony there was a feeling that, after the birth of a child to a couple, one of whom was living at a distance from his parents, a visit which seems to be ceremonial should be made to the distant parent. Coyote taunted Crane that he had nothing to give his in-laws (8). Each of Crane's wives had a child and the purpose of the visit was to show the children to their grandmother. A large quantity of meat was brought as a present, enough for Crane's mother-in-law and for all her tribe.

The woman who married a dog (11) requested that they go back to visit the husband's kinfolk. This may have been because they were both misunderstood by the girl's own relatives rather than because of custom. The two tales of the Water Monsters desiring human food seem to 
show that a family expects the son-in-law to bring his wife and child for a visit. That was how Catbird came into their power (22), and they got the family of the cruel boy in the same way (27). Except for the return of Crane no mention of gifts is made. It may be that, since gifts are so commonly exchanged by visitors, there is no ceremonial significance especially attaching to these visits of spouses to their in-laws.

A custom not noted by Teit is that of payment for damages. It was important in settling feuds. The chief of tales $9 \mathrm{a}, \mathrm{b}$ had done Lynx a great injury by humiliating him and deserting his wife and child. Such an offense could be atoned for only by offering, not only valuable gifts, but the most precious things the offender possessed. In this case the villagers took everything they could think of, but Lynx's wife scorned their gift because the only thing she wanted was Bluebird's blue coat. She finally got it and all was well once more with the village. This scene of the Lynx story is in absolute agreement with actual life. After Chief Waxane had revenged himself on the Ugly People for taking the girl sent to him the mother and children were left. Then Waxané had his people gather a pile of valuables which they gave to the survivors of the Ugly People as damages before they took them into their village (41).

An amusing story from the childhood of Tom Miyal is another example of how important it was considered that damages be paid. When Tom was about eight or nine he had a fight with another small boy in which he came out victorious. After the fight was over Tom was told he must pay the boy to prevent ill feeling. Naturally a child had few valuables, but Tom cherished a small cup of brown sugar. This he was urged to give to the injured boy and he did so, but he never forgot how much it pained him to do so.

A person offended draws his blanket up over his face and sulks (1, $4,13)$. If the cause of his grief is an offense he answers nothing when addressed by other members of the family or community. A woman does not cook, a man refuses to hunt or fish. In such case it is the duty of the others to discover, by sifting the possibilities-the aggrieved one furnishes no clue-whereby they might have offended. If they hit upon the right one they atone in some way, usually by yielding the point. It can readily be guessed that it is not always easy to spot the transgressor. If he is found there are all sorts of things which may be tried. Suppose, for instance, a husband has offended his wife. He has been active all day about many things any one of which might be a cause $(4,13)$. It sometimes requires several days of thought before a husband discovers what his wife is sulking about. There is no doubt that in Coeur d'Alene circles the system works. A man does not like to cook his own food, nor does 
he enjoy living with a sulking woman so, as soon as he discovers the cause, he sets about finding a remedy.

In life as it is today closely tied up with white culture the probabilities for offense are too numerous and outsiders care too little to offer a solution. Even then the Coeur d'Alene woman sulks until her husband does something about it. One of my interpreters (a woman) and I had been working in a most pleasant way with a man and his wife. They made great sport over my grasp (!) of the language and for several days we worked amicably. The informant was jolly and seemed to enjoy the work. His wife listened to us, laughed at our jokes, and seemed in every way to cooperate, even suggesting stories for him to tell. One day however we went to their home to set a time for future work. This day we found the exact story setting: "She was silent. She paid no attention. She did not speak." It was almost impossible to get any information from the wife. She answered in monosyllables. We decided to leave and gave her a message for her husband. The interpreter was almost sure she would not deliver our message that we were coming for more stories early the next morning, so we acted on this basis and were there before the informant could leave. We caught him just as he was driving off and he promised to work the next day. We came at the appointed time. The informant kept seriously to short tales; he rarely laughed, had no vivacity and at the end of the morning made many excuses (all ridiculous) as to why he should not work with us any more. On this day his wife stayed out of the room, came in only once or twice to get things and then did not greet us but kept her eyes on the floor. The interpreter might have been expected to have ascertained our offense. To date many years later she is as much at sea as I am. She knows and I know that the woman won. We can joke about it, she and the informant can joke about it (I have this from a letter), but for our practical purposes the wife is still sulking.

Situations like this are of course conducive to narrative. One can easily imagine how a protagonist might try many solutions in vain and thus spin out the tale indefinitely. However the custom is not used so extensively as to become a repetitive device but only often and vividly enough to show the custom clearly and to influence the plot.

According to the myths the appearance of grief after a death (or desertion) was the same as that of sulking. The survivor pulled his blanket up to his face, sat and wailed or just sat. Little Mosquito (28) and the chief's daughter $(9 \mathrm{a}, \mathrm{b})$ showed in this way their grief at being deserted as did Coyote at the loss of his children (3). This ostentation lasts four days. The mourner then gets up, purifies himself by sweating and bathing and is ready for new experiences. The repetition of the 
purification for four days is doubtless formal rather than actual for Teit remarks that the period of mourning varied for different individuals (ARBAE $45: 175$ ).

It was customary to wail over a corpse as evidenced by the historical tale 40 , and by observation.

Teit records that a death was announced. Myth furnishes additional details about the method which was apparently used when people died away from home. The announcement was made by hammering on a canoe. The people then came out of their houses to hear who had died. The ones in the canoe then chanted the name of the deceased ( 3 ).

Mourners, according to the myths, were accustomed to use "backward talk." Instead of singing the praises of the deceased, they referred to his defects. Coyote thus mourned for Cricket when he thought he was dead (18):

" $\AA$ wä wä, should I be mourning his big belly?

“ $\ddot{\mathrm{A}}$ wä wä, should I grieve for his stitched-up belly?

" $\mathrm{A}$ wä wä, is it the back of his neck that is pitiable?

"đ̈ wä wä, should I mourn because he spits?"

When Coyote argued with Antelope (3) as to whose children had been killed it was in the same vein, but one mentioned the defects of the other's children:

Antelope: "My children are not so lazy they would be killed."

Coyote: "Do my children not go to rocky places and eat rosehips for days on end?"

There is a hint (not corroborated by informants because they did not remember it) that contamination with the dead was thought to spoil a hunter's luck. After Coyote had killed Deer and his family he said Mole might spoil his hunting luck (6). This may have been a general belief but, on the other hand, it may have been Coyote's persistent scolding. One should be wary, as are the Indians, of taking Coyote's behavior as final evidence when no check is available.

The myths allude often enough to games but furnish us with no additional information regarding them because they are not sufficiently specific (cp. ARBAE $45: 130$ ). Coyote in Gobbler's stomach saw people playing the hand game and "cards." They were also dancing the war dance (2). Coyote and Fox gambled with the fish playing the hand game (12). When Dorothy and her sister went on the buffalo hunt they got acquainted with two Blackfoot girls and they used to play it. She described it as follows. They had two little sticks just large enough to hold in the closed hand. One was plain and one had a black band. The player took one in each hand and sang. The opposite side guessed in 
which hand the plain stick was. The counts were for sides. Little sticks were laid on the ground and used for counters. These girls used to bet a small string of beads or equivalent trifles (cp. ARBAE $45: 131$ ). Coyote and his party used pheasant tails as pawns (12).

Chief Child of the Root played the hoop and pole game with Splinter Leg (1). This game was described by the informant exactly as Teit has it (ARBAE $45: 131$ ).

Dancing was a favorite amusement ( 7 ) but no detailed description of social dances is given. It was customary to have a war dance before setting out on the warpath (37; ARBAE $45: 188$ ). Turtle scalped the $\mathrm{Nez}$ Percé chief, brought back his scalp and danced with it (37), Coyote scalped Mrs. Deer (6), Snake held a war dance after he captured Salmon (10). The stem for "dance a war dance" means "to make fun of the enemy." There is no evidence in the myths of counting coup, or of recital of war exploits although Teit records both as customary (ARBAE $45: 189$ ).

Belief. A number of miscellaneous beliefs can hardly be put into any category. Coyote's fear that Mole would spoil his hunting luck (6) has been mentioned. It seems most likely that this was through fear of contamination with the dead although Coyote himself was not free of it for he had tortured Deer to death.

Dreams were undoubtedly thought of as prophecies $(42,44)$. Evil befell him who persisted in the face of a dream warning. A boy who was instructed to seek a vision had a pre-vision which portended danger (42). This vision should be differentiated, I think, from dream and the vision ordinarily sought and obtained by Indian boys. It is the stereotyped sort learned from the Whites, a beautiful woman in a shining light, the whole so dazzling as to stun the observer. Nevertheless the prophecy was more powerful than the power the boys were to receive in their own seeking for they were killed and only the one who obeyed the woman was saved. This is of course an historical tale and it is easy to see how this element comes into it, but it also-suggests that the Coeur d'Alene stressed their own "guardian spirit" interpretation of Catholicism.

A girl dreams that the enemy is near the women gathering serviceberries (44). Dreamers warn but are not heeded. Their warnings are believed only after the damage has been done. There is no evidence of dreams not coming true although the skeptical attitude suggests that there must have been many false alarms.

There is great fear of the abnormal or the unusual. This is brought out nicely in the experiences of the cruel boy who fished up incomplete and unnatural fish (27). The same fear was exhibited in the encounters with dwarfs (39). They are small and hang upside-down on 
branches of trees. Consequently one does not welcome meetings with them.

One of the texts is a vivid description of a boy's quest for a guardian spirit (42). According to Teit it was similar among the Coeur d'Alene and Thompson (ARBAE $45: 192$ ). Boys and girls went through the purification but boys secured guardians much more frequently than girls. However if there were no boys in the family a girl could act as substitute. Julia's mother's father had three daughters but no son. The oldest girl secured a guardian which gave her sufficient power to help her father when he made magic. She could, for instance, take hot stones out of the fire with her hands without getting burnt.

Purification is carried on by means of sweating and bathing. The tale Turtle's. War Party suggests that people sweated every day, for the people of the village passed the Chief's house on the way to the sweathouse (37). Otter's sister, Mink, took a regular bath (30). She made a hole near the shore just large enough to sit in; the water flowed into it. Then she put hot stones in to heat it and was just about to go in when she was shot. According to informants it was customary for every one to take baths like this. The Coeur d'Alene say the Nez Percé who are considered "very dirty" still bathe this way. While a Nez Percé Indian is in the bath he puts a long feather down his throat to induce vomiting. This is to clean out the heart. ${ }^{1}$

Teit describes the Coeur d'Alene sweathouse as small, domelike and typical of the Plateau area (ARBAE 45:62). A description in Coeur d'Alene style makes the picture of the sweathouse very vivid. The mother of the kidnapped boy hid herself near the sweathouse where Meadowlark had told her the son would sweat. "She saw her son, who was now a man, make a fire. It got redhot. He put rocks in it. Then he went in feet first" (24). The fire was made in a hole at the side of the sweathouse. A long time ago the people used a cave for a sweathouse but one time a number of them in it were scalded to death. Since then they have used the one made of a bent willow frame covered with bark, mats or skins.

A few cures are vaguely mentioned. Muskrat's grandmother sprinkled his head with water and bound it up after it had been bruised and flattened by Otter. She also pretended to be curing it the same way when Otter arrived at her home to avenge his sister's death (30). Coyote chewed willow and stuffed it in the hole in his leg (6). He was given fat as a cure for blindness (7). With the exception of the first there is no reason to believe that these medicines were actually used.

${ }^{1}$ The Coeur d'Alene believe the heart (stomach) is the seat of thought and right-doing. 
Much of a tribe's ethical code is embodied in its myths, but it is rarely practicable to interpret ethical or moral manifestations from the myths alone, for we are far too likely to project our own evaluations into those of another society. I do not know, for instance, why Lynx (9a, b) should have been so severely punished as he was. We should say offhand that he was punished because he was the father of the chief's illegitimate grandchild. But when we know that the stigma attaching to illegitimacy is felt less keenly by the Indians than by us, it is necessary to reinterpret this incident. My guess is that the episode, being a European one, was made over into a Coeur d'Alene story with little regard for the original theme. The motivation here is desertion, there must be some reason for it, so the blame is at first put on Lynx. The punishment is then stylistic rather than moralistic as is evidenced by the poetic justice meted out at the end of the tale.

Another example illustrates the reverse case. The chief's daughters stole dentalia, treasures he was hoarding for the use of his people. Again desertion is a motivating force but this time it is induced by a strong moral obligation. The chief, much as it grieves him, must exact of his own daughters that punishment which he would decree for any of his tribesmen had they erred in the same way. His obligation to his fellows far outweighs his own feelings in the matter. "My own children have stolen the bones. That is what grieves me so. It wasn't your children but mine" (24).

Two practices in our own society practically disqualify us from understanding the chief's attitude and solution of his problem, our emphasis on material gain and the tendency of parents to defend their children even when they commit crime. A modern American in the position of this mythological chief would be much more likely, I think, to transform more bones into dentalia to pay for covering up his daughters' crime.

These examples serve to point out how cautious one must be in evaluating such moral ideals. There are however numerous cases where a detailed knowledge of the culture and people together with the evidence of the myths shed much light on their ideals and practices.

One of the most universal traits of man is his inconsistency. The Coeur d'Alene are no exception. They are not only cruel but they are proud of it and, on the other hand they are compassionate. There is marked scorn for certain types of behavior exemplified by Coyote-his greediness, trickery, cruelty, lack of originality. Treason is condemned. The traitor Coyote who abetted the man-eating Grizzly (6) and the Meadowlark who took up with the Wolves (10) are held in the greatest contempt. In this connection I might add that many of the Coeur d'Alene regard their 
interpreters and policemen as stool pigeons. Their attitude is in many cases unfair for, if the interpreter has the welfare of his tribesmen at heart, he conscientiously translates their thought. However since almost all decisions are against the Indian, his tribesmen conclude, though in some cases unfairly, that the fault lies at the door of the officials, so they are considered "traitor coyotes."

The episode of the "Deformed Transformed" has in most cases a moralistic element which might be formulated thus: The old or ugly may have great power. They may choose sometime to exert that power and when they do, woe to the one who has offended them (11). It is impossible to judge whether this idea, an intrinsic part of the plot, has been adopted along with it or whether it is an old attitude. It is quite likely that the latter is the case so that no alteration was necessary when the plot was adopted. Certainly it fits in well with practice. Old, decrepit or abnormal people may be teased occasionally but they are not mistreated as were the dogs of tale 11 . They may be neglected by the younger members of the tribe but a negligent grandson is shamed or reprimanded by his elders. A boy may leave his helpless grandmother for several days at a time or longer but he does not refuse to help her when he is at home, nor does a "decent" Coeur d'Alene intentionally ignore distress in his immediate surroundings. Neglect of the old and helpless is naturally more prevalent in these days when the attention of the young is so easily diverted and when all tribal control has broken down, but it is never condoned.

The teachings imply that laziness is almost a crime. Girls past ten who leave the village to play with the smaller children (31) or to play in the wood (24) are punished by desertion. At first glance it seemed to me quite commendable that the girl of tale 31 took care of the little children and kept them out of the way of the villagers. The Coeur d'Alene do not see this point but feel only that the girl failed in not taking on her share of work. The Dentalium Girls added to shirking responsibility the offenses of deceit and lying (24). History records the feeling against deceit and lying in the musings of the Boy of $\mathrm{My}$ Story (42), "When my father calls I won't go (to the one-night camp). If I do I'll only pretend. I will really go to my father's brother because he lives near where my father told me to go. Yet if my father finds out I have deceived him he will kill me. But then if I crouch nearby I'll become a stone, for my father says children who are stubborn and disobedient turn into stones."

The above quotation says much about the respect children had for their elders and there is also a nice balance in the feeling that parents should not be unreasonable with their children. When the boy refused to 
go his father was disappointed and disgruntled and put him down as disobedient. He felt perhaps that he wanted him out of his sight and sent him for water. The boy went at once, whereupon the grandfather pointed out to the father that the boy was not habitually disobedient nor did he refuse to go for water, but was even willing. Perhaps he had a good reason to delay his one-night vigil. Another angle is shown a little later in the narrative when the father asks the boy why he did not give the reason for his refusal to obey and he answers, "You would not have believed me."

Parents should be strict with their children in order to make them "decent" people but, as soon as they become unreasonable, sympathy is immediately transferred to the children. Another example of this attitude is that of the boy who took a piece of the good meat without his parents' permission. The Coeur d'Alene do not approve of "thinking more of food than of your children" (46).

Opposed to the attitude of obedience are examples of disrespect with even a threat of violence. Child of the Root gained his point by threatening to kill his grandmother and came temporarily to grief (1); Catbird upon every occasion disregarded his grandmother's advice and won his point but, when he failed to heed his grandfather, he got into serious trouble $(22 ; \mathrm{cp} .27)$. In all of these cases the children had supernatural power, while the parents disobeyed with impunity were only ordinary people. As soon as the elders secured greater control over the abnormal the children failed. Here there is rather a reflection of the attitude toward supernatural influence than toward filial piety. Catbird's grandmother was a symbol of reaction who considered everything in the least unusual impossible of accomplishment. This may well go into the category of parental unreasonableness.

Ordinary disobedience to those in authority had its penalty as is shown by those who disobeyed orders $(8,9)$. The high ideal of chieftainship is exemplified by the father of the Dentalia Girls (24), the father-inlaw of Lynx (9a, b), and Chief Waxane' (41). A chief felt obliged to submerge his own individuality and emotions in the good of his villagers.

Conservation was a policy carefully practiced for the good of the community in myth if not in actual life. The most important hunting rule was, "Take one just big enough, not too large or too small. Then use it all" (1). And of deer, "Never shoot more than two apiece" $(13,23)$.

Much stress is laid upon the dispensation of food. A stingy person was despised. It was proper to have enough food for the guests to eat to repletion and to take some home, perhaps enough for their families 
$(8,9)$. Chiefs were expected to share food with the whole village. A bad breach of morals and manners was Woodtick's. When Coyote had come to her house, hungry as usual, she set places for two but, since she did not say, "Come eat," he sat and watched her eat and clear the things away. She showed her willingness to share the food-a moral obligation -but she did not add the verbal invitation-a matter of etiquette. The fact that it was observed by Coyote who more commonly disregards all forms of decency makes Woodtick's lapse the more pointed (16).

Reciprocity is strongly emphasized. It crops up most often with regard to food. Magpie and Rabbit were rewarded with plenty for themselves and their families because they brought their blankets to Lynx's baby (9a) or, because they stamped lightly on Lynx (9b). Coyote may be expected to return evil for good, ingratitude for help, but there are occasions when even he is helpful. He fed Little Beaver through his training period, no light task, and Little Beaver in turn avenged the murder of Coyote's children (5). Rabbit and Jack Rabbit lived in a state of mutual friendship, each was so concerned about the other that he constantly had new ideas of helpfulness, even if they proved superfluous (35).

Just as the Coeur d'Alene take pride in certain types of cruelty so they admire bravery. Clean Face came down in history as a hero, for single-handed he defended himself against the enemy (42). The intrepidity of Reserved and Quiet is extolled (10). Reticent was afraid but Quiet kept his head and saved the situation. There is a tinge of scorn in the remarks about Reticent. Courage was not a characteristic of men alone. In describing the dauntlessness of women frequently exposed to danger narratives express also great admiration for their cleverness in solving problems. A woman, seeing a chance to escape from her captor when his saddle cinch becomes loose, takes it (44). Much pleasure is taken in the account of the two old women who while camping saved themselves from the enemy by throwing a pot of boiling mush into his face (43). A number of elements in this narrative make for enjoyment, the cleverness of the ruse, the fearlessness of the women in carrying it out, the humor of the situation-the enemy surprised and spitting hot mush and, not the least, I suspect, the suffering.

Since Coyote is the chief protagonist of the tales it is not to be expected that modesty would be outstanding for he was never modest-if upon occasion he was, it was a matter for suspicion. Nevertheless modesty was an ideal. A girl would look up when a stranger entered, then down at her work at once. Thus Woodtick behaved when Coyote entered her house (16). This might be a misinterpretation in that Woodtick did not notice Coyote because she was offended. She was however always 
intimidated by the fact that she had no neck. Bullfrog is the most modest character. She is ugly. She was reminded daily lest she forget it. She accepted her position as the ugly one and, instead of becoming arrogant and aggressive, effaced herself to the extent of offering herself as a sacrifice to the beautiful and young (31). Examples of exaggerated modesty are Lynx (9a, b), Crane (8) and, above all, Chief Child of the Root (1). In these characters are blended bravery, power and success with moderation, humility and generosity, a combination greatly esteemed.

A study of the Coeur d'Alene linguistic categories, some of which have been elsewhere discussed (American Speech 18 [1943] : 96-102; Handbook of American Indian Languages Vol. 3) gives further insight into psychological notions. A verb-stem neatly sums up an ideal constantly held in mind. Children should be brought up to be "decent." All of the qualities previously mentioned as laudable should be encouraged. Coercion may even be used. The moral code which posits the type of behavior for "my folk" and "alien folk" is thoroughly understood and insofar as possible followed. The individuals who get away from their training for some time become "indecent, not like a person, untrained, unrefined, uncivilized." Then they are not "real people" and are looked down upon just as we scorn those who are dirty or unsanitary. Thus myth relates and explains some of the Coeur d'Alene ideals of superiority and inferiority which are chiefly a matter of cultivation.

The available body of Coeur d'Alene mythology, though small, serves to acquaint us with thoroughly realized literary devices and with cultural values of a kind not ordinarily ascertained by the usual ethnological techniques. Although one must always consider myth clues suggestive rather than conclusive there is ample evidence that they define attitudes toward the culture and ideals which delineate the more subtle and deeply rooted ethics of human behavior. 


\section{CHAPTER IV}

\section{Diffusion and Mythological Processes}

Just as this small body of texts illustrates the possibility of determining literary style and contributes illuminating features of culture, especially of psychological understanding, so the distribution of whole tales, episodes and elements illustrates myth processes. Miss Froelich had all of these things in mind when she made her comparison which she did not restrict to plot and catchword titles alone. A perusal of her comparisons brings out quite clearly whether we have the same story or whether only episodes or even psychological themes are repeated. She has also been aware of stylistic problems and has included insofar as possible suggestive remarks on these subjects.

It is possible therefore to determine quite readily the distribution and distinction of certain plots or episodes as well as to see the relationship of mythical notions and historical happenings. Myths which may, with only few qualifications, be considered "typically northwestern" are: Chief Child of the Root (1) ; Origin of Indian Tribes through transformation of the parts of a gobbling monster (2); Coyote Steals his Daughter-in-law (4); Story of Lynx (9); War between Land and Water People, a tale which gives some insight into Plateau ideas of water spirits or monsters (10); Catbird (22); parts of the myth of Water Monster Woman, another related to under-water spirits (27); Little Mosquito (28); and possibly, Coyote Marries the Sister of Geese (13).

Having a much wider distribution, in this study only sketchily indicated, are the themes: Eye Juggling (7) ; Bungling Host (14) ; Calling the Deer (16); Rolling Rock (Skull) (19); Snaring the Wind (21); Substitute Bridegroom (mate) (23); Contest between Cold and Heat (34) ; Dog Goes for (procures) Fire (36); and Mock Plea (37).

The Coeur d'Alene use of these themes is sometimes distinguished by the combination of the themes, at others by the interpolation of a characteristic episode, introduction or motivation. The Dog Husband theme which has a wide distribution is uniquely introduced by the special treatment of the Deformed Transformed theme and the jealousy of the sister. The good-humored playfulness of the Dogs, the behavior of the human girl child to her dog brother, the emphasis on loneliness as an excuse for abuse and the mother's intervention (11) also take the tale 
out of the class of the type Dog Husband myth. The myth of Coyote disobeying the Geese or other birds with great flying power has a relatively wide distribution but the introduction in which Pine Squirrel provides him with teeth is somewhat unusual (13).

The myth of the Girls Who Stole Dentalia from their father, the chief, is fashioned upon the pattern of the Lynx story, disgrace and desertion by the tribe and similar motivations are found in comparable tales. The kidnapping of the Coeur d'Alene tale which is carefully developed sets it off from the others and makes it a gripping plot well sustained until the very end when it falls flat (24).

The following are distinctive of the Coeur d'Alene: Little Beaver (5) which has only one parallel, among the Okanagan; Coyote Hunts with Crane, whose introduction which might well be a separate tale is unique, but which ends with the Salmon Release, a theme of wide distribution (8) ; Coyote and Fox Gamble with the Fish (12); Coyote and Badger (15) which has only one analogue (among the Columbia River Indians); Calling One's Kind (17) ; Coyote Kills Cricket with Elk Fat (Mistaken Kindness) (18) ; Cricket Rides Coyote (20); Thunder (25); features of Waterbird Contests for Woman which distinguish the treatment of the more usual Gift Test theme (26) ; Grizzly and his Brothers-in-law (29) ; Muskrat Trespasses (has two comparable analogues [Shuswap and Coast Salish] but the details are not very close) (30); Toad Saves Children (31); Elk and Snowshoes (33); Rabbit and Jack Rabbit (with one almost identical parallel among the Nez Percé) (35); and parts of Turtle's War Party (37), said to be historical.

It is quite possible that some parallels may be found for some of these or parts of them in Plains mythology to the east and south, but it seems reasonably safe to consider these as Coeur d'Alene contributions, if not entirely, at least in the distinctive modes of treatment.

In most comparative studies more attention is given to myths than to tales and historical narratives. This is of course justifiable since they are proportionately much more numerous. In considering such tales from this collection several illuminating points emerge: 1 . There is a gradual transition between pure myth and history. 2. Themes which were either derived from actual happenings become myths or the reverse. 3. Mythical incidents may be identified with known human beings so thoroughly that they cease to be mythical. Turtle's War Party (37) is an example which possibly illustrates any of these possibilities. The characters have mythical names and the Mock Plea incident is well known and widespread, but the explanation that a Nez Percé chief was actually killed in as mysterious a manner as the tale relates suggests 
some authenticity. It is also possible that the tale is symbolical or allegorical in the same sense as the myth of Little Beaver.

Dorothy's remarks and beliefs about the two-headed snakes (38) show the impossibility of thoroughly disentangling actuality and myth. In every Indian tribe with which I have worked there is a conviction that two-headed snakes actually existed or even exist now. I always ask if the informant has seen one and never have I found the evidence closer than once removed. Dorothy's father saw these snakes, the most elaborate I have ever heard described. In other cases it was an uncle or a cousin, the informant having arrived just too late to have seen them himself.

The narrative of The Dwarf (39) was told me after I asked if there was any such thing as a dwarf, since none of the tales included any such references. It was told as an actual happening, all proof being inherent in the tale. Tales $41,44,46$ and 47 may appear quite "obviously" true if the comparison did not show that 41,46 and 47 were quite intimately connected with mythical elements, the parallels of which point to the Northwest Coast. As the Coeur d'Alene treat them they are very convincing, since they contain nothing mystical or imaginative, but the other comparable tales seem more mythical than real. One reason for this of course is the fact that Indians describe and motivate their characters in a realistic way, connecting them and their behavior so closely with the supernatural and mystical that one often forgets that the real and the imagined are not the same. It is reasonable to assume that such elements originated in historical occurrences but there is at present no way to prove that they were not lifted from myth and made real. 


\title{
CHAPTER V
}

\author{
The Myths and Tales
}

\section{A. 1. CHIEF CHILD OF THE ROOT (TRANSFORMER)}

Child of the Root's grandmother reveals to him his origin

Child of the Root leaves home

Chief Child of the Root:

Transforms Pestle Boy into pestle

Instructs Foolhen to eat moss raw instead of falling into fire to cook it

Kills and revives Fisher to overcome his foolishness

Burns awls, combs, bladders and lassos to make them useful to man

Transforms nails and bill of Kingfisher and Fishhawk to enable them to catch fish, enjoins them to eat fish raw

Instructs Splinter Leg to enable him to make spearhead of elkhorn instead of his own leg bone

Toad causes flood so that Chief Child of the Root will visit her

Toad jumps on Chief's forehead

People reject Coyote and Robin as sun and moon

People accept Chief Child of the Root as sun, Helldiver's child as moon

An old woman lived with her daughter who had a baby. Every day the daughter went out to gather the root of the plant called sp'ä'xwäntc (probably hogfennel). Every day she came back with a great many of the roots. She baked them and the family ate them. The boy grew. The mother always went out alone to gather roots, leaving the boy with his grandmother. One day when he was quite large he asked, "Where is my father?" "You are pitiable. You have no father." "Why have I no father?" he asked. "He has been dead a long time." "What was his name?" "He had none."

Then the boy took a stick and threatened, "If you don't tell me who my father was I will kill you." "You are Child of the Root," confessed the grandmother.

The boy was sad. He lay down and covered himself with his blanket. All day he lay like that. In the evening when his mother came back and saw him lying as he was she thought, "I suppose his grandmother has been telling him tales." She said nothing but made signs that she was going to club her mother. After she had cooked the roots, she said, "Come, we are going to eat!" The boy paid no attention. She and her mother ate but the boy would not join them. The next day the same thing was repeated. He refused to eat. The mother went out to gather 
more roots. After she was gone the boy got up and said to his grandmother, "I am leaving you for good."

He went out. He went to the edge of the water and sat down. He sang, "ahoiye xiyä, Chief Child of the Root xeya, xeya." He washed his face, his head and his entire body. He reached into the water and took out the throat of a monster fish. He made a canoe of it, got into it and rowed away singing his song. He heard someone who said, "Chief Child of the Root, give me a ride. We'll see the whole world even to where the river enters the sea." "All right, I'll give you a ride."

Then the passenger, who was Pestle Boy, jumped up and down in the boat. "You might break my canoe. Here I'll fix a paddle for you to sit on." He fixed it but Pestle Boy continued to jump up and down until Child of the Root dumped him into the water. "You will no longer eat people. They will use you for a pestle," he decreed.

The Chief went on singing. Suddenly he saw a tree burning. Someone fell off it into the fire. He thought, "That person will die." He hurried ashore and looked. He found Foolhen feeling her eyebrows. They were all red and blistered from the fire. Chief Child of the Root said to her, "What's the matter?" "Hu uh-um, Chief . .." (She did not say "Chief Child of the Root," but only "Chief."1) "I was gathering black moss." He said, "Don't do that any more. You might die. If you get hungry for it again, fly up to a tree and eat it raw right off the tree. Eat it all up, as much as you want. Don't have a house anymore and don't try to cook it!" "Thank you, Chief !"

Before this she had gathered the moss and put it under her wing. Then she set the tree afire and cooked the moss by falling into the fire herself.

He went off again. Suddenly a rabbit jumped into the water. Chief Child of the Root clubbed it and put it into his canoe. He went on. $\mathrm{He}$ heard, "Ulu'lu'lu," the sound of tramping. He saw Fisher. "Chief Child of the Root, give me my game," he demanded. "No, I didn't see it!" Fisher jumped into the water. "If you don't show me where it is I'll slap you with my tail." "Go ahead, slap me with your tail!" Fisher jumped about in the water and swam until he got close to the chief. Then he turned around and slapped the water with his tail. He got the chief all wet. The chief hit him. He died. He put him into the canoe with the rabbit and paddled on.

The chief came to a place where there were many children. He went ashore. When the children saw him they ran into the house. Their mother asked, "What is the matter?" They did not answer. Chief Child of the

${ }^{1}$ Those who were kind called the hero "Chief" and he helped them, those who called him "Chief Child of the Root" insulted him and were overcome. 
Root came in. The mother looked at him and said, "Hum, hum, Chief, you honor our humble home." He sat down. "We are pitiable," she added. "We have nothing to offer you to eat." "No, I am not hungry," he said. Soon she told the children to look for their father. They looked for him but soon came back and reported, "Our father is gone." "I guess he is hunting. He'll be back. Maybe he has killed something. Then we can eat."

The chief looked around. He saw a lot of rabbit skins. He thought, "They must like rabbits." He told the children to get the one from his canoe. They went to the canoe and saw their father lying dead in it. They cried, "It's our father lying dead there in the canoe!" The mother said, "I suppose he was doing something foolish again." When the chief found it was their father he had killed, he said, "Go get him. He will come back to life again." The children brought him up and laid him down. The chief stepped over him. Fisher got up. "Oh Chief, you find us humble," these were the first words he uttered.

The chief went on. He saw a house with smoke coming out. $\mathrm{He}$ thought, "That's where I'll eat." He went ashore. There was a good fire burning in the house but the people seemed to be gone. He saw little awls hanging all over the walls. In the middle was a large one, nicely beaded. He went over and took it down. As he was going out with it all the awls cried out, " $\mathrm{He}$ is taking our chief," and came down from the wall and pierced him all over his body. "Don't do that! I guess it must be your chief I took." He hung up the ornamented awl and went out. He set the house afire. As he went off he heard the awls crying, "Yar, yar, yar!" He said, "Don't be man-eaters anymore. You'll be used for making moccasins."

He went on. Farther on he saw something which looked like a house. He went in. No one was at home but the fire. He saw combs hanging all over the walls. A large one decorated with beads was in the center. He thought, "I'll comb myself with that nice one." As he went out with it the others cried out, "Our chief is being taken away," and they all came at him and combed him. "Oh! It's your chief ? I'll hang him back again." He hung it on the wall, went out and set fire to the house. As he went on he heard them shrieking (like scared chickens). "Don't be man-eaters! You'll be used to comb hair," he commanded.

He went on and saw another house. Inside there was a fire and the walls were hung with bladders. In the middle of a wall was a fine large one. "I'll take that for my own use," he thought, "I'll keep my kinnikinnick in it or I can use it for my powder." He took it, but just as he went out he heard crying, "He took our chief !" He felt them all bumping him and some blowing him in the face. "Stop that! It's your chief. I'll put 
him back," and he hung it up again. Then he went out, struck a light and burned the house. He heard bursting of many tight skins as he went on. "No more will you be man-eaters. Hereafter you'll be used for storing tobacco."

At another house the walls were hung with lassos with a large fine one in the center. He had no more than taken it down when the rest all cried out, "It's our chief !" They came down and lassoed him and he put it back. He destroyed the house with fire saying, "No more will you be man-killers. You'll have to make your living. When people want food they will use you to trap their game."

The Chief went on. He saw Kingfisher sitting on a tree. As he was looking Kingfisher dived. Soon he came up holding his hair in front with both hands. He ran into his house and soon came back with a bucket. He filled it, ran back and built a fire. Child of the Root thought, "I better look into this."

He sneaked up and peeped in. He saw Kingfisher had hold of his hair and was washing it in the bucket. He was wiping his hands on his hair because the fish smell was all that there was left of his catch and he was making soup of it. The Chief went back to his boat and returned as if he had seen nothing. "You honor a humble home, Chief. I am too poor to be decent." The bucket was boiling. In it was what Kingfisher had washed from his hair. "I am poor, I have no food." "I am not hungry." "If I had something to eat you could eat with me." The kettle boiled, it got white on top. Kingfisher set it down and said, "Stay and have a drink of soup." The Chief took a cupful and drank. He had never tasted such good soup. He drank it all.

"You should have had something to eat," said Kingfisher. "I guess you saw me when I dived for a fish. I got hold of him but he slipped away because my nails are too short. Why is it they are so close to the flesh?"

The Chief took Kingfisher's hands, put something like a cat's claws on them and they became long. "You can do anything you want with them now." Then he opened the bird's mouth, took a knife and cut his bill in several places so it was like a file. Then he said, "Go try it. Get a fish."

Kingfisher went out to his tree and sat. "Tsalalala," he dived. He got his fish, bit it and held it fast. He took it back to the house. "Thank you, Chief," he said. He got a bucketful of water and cooked the fish. He was very grateful. Then the Chief said, "Now I must go." "No stay and eat."

"I drank some soup. You eat what you have. Eat it all. Then fly. Don't live in a house. Go sit on a willow and watch the water. Don't take the big fish or the small ones, but the ones that are just big enough 
for a meal. Don't cook your food but eat it raw." "Thank you, Chief, thank you."

The chief went on. He saw someone jump into the water and come up with clasped hands. This person also ran into the house, brought out a bucket, filled it and went in to make a fire. The Chief spied on him and saw him wringing the ends of his fingers in the pail. He withdrew and came in openly.

"Oh Chief, you find me humble, I am poor." When the kettle boiled Fishhawk gave the Chief some soup. It was very good. Then he said, "If it weren't for my fingernails I would have plenty to eat. I guess you saw how I tried to catch a fish." "Let 11e see your hand." The Chief treated the nails as he had Kingfisher's and they became long. Fishhawk tried them and came gleefully back with a stickful of fish. "Thank you, Chief. Stay and eat with me," he invited. "No! I have eaten. You eat it by yourself. Then fly. Don't have a house. Don't cook. Eat your food raw. Take only one fish and eat it all." "Thank you, Chief."

The Chief paddled on to where the brook ran into a river. There stood a man aiming a spear. He saw that one of the man's legs was extremely thin and wondered why it was. He thought, "I ought to see it right." $\mathrm{He}$ jumped out of his canoe and turned himself into a salmon. He swam up to Splinter Leg. When he speared him he ran off so the spearhead broke the line. Splinter Leg cried "Oh! It hurts after all my suffering."

The Chief got into his canoe and speared a salmon with the same spearhead. Then he went back. Splinter Leg was gone. He went to his house and peeped in. He was cutting another spearhead out of his own legbone and crying, "änininin hä hä hä." The Chief drew back, then walked in. Splinter Leg covered his leg with his blanket, "Weak, poor, and pitiful you find me, Chief. I have nothing to eat." "I am not hungry." "I would have something to eat for just as you came in sight I speared a salmon, but my line broke and carried off my spearhead."

"I saw a fine big salmon lie in the water with a spearhead in it. That must have been yours. Go get it from my canoe."

As Splinter Leg got up he quickly drew his blanket around his leg. He brought the salmon back, cooked it and served it. They ate. The Chief kept watching the other's leg, but Splinter Leg took care not to expose it.

"Let's play a hoop and stick game, proposed the Chief. "No, I don't know how." "All right." "Oh well." "What will we bet?" "Your blanket." They played. Child of the Root won. "Now your shirt." Again he won. "Come now give me your blanket."

The Chief hit Splinter Leg with a stick. His leg broke. The Chief took the blanket. "You've made me more pitiable, Chief." "Let me see your 
leg." He looked at it. "Why did you do that?" "Because of my spearhead. I had to carve it of bone." He did nothing but cry, "Now you've made me much worse." "I only did it because I mean to fix it."

He saw that the one leg was as thin as could be, the other was normal. $\mathrm{He}$ rubbed the leg and smoothed it and it became as good as new. Then he took the blanket and handed it to its owner, "Here is your blanket."

"Go ahead, take it," and Splinter Leg was going to take off his shirt. "No, keep them." "Thank you, thank you!" The Chief went out. He came in with something in his hand. It was elk antler. "After this make your spearhead of this. Don't cut yourself for it." "Thank you, thank you!"

Again he paddled away. After going a long way he saw many people. They saw him too. "He is coming, Chief Child of the Root," they cried.

Two of them came to meet him. They carried him in by the arms. The chief of the people said, "I have two daughters, they are yours."

It was so crowded that Toad was pushed way back and could see nothing. This always happened to Toad because she was so ugly. "I must see him too," said Toad stretching as high as she could. "What's the use of your seeing him, an ugly thing like you?" "It's true I suppose," agreed Toad ruefully.

She then went out for water. She sprinkled water from the sky. She went into her house and sat down patiently waiting. It rained, it poured. Everybody went home. It was so wet in the houses no one could lie down. Chief Child of the Root tipped his canoe over to lie under it. Soon it was wet there too. He got up. He saw a light far off. He went in the direction of the light. It was in Toad's house. She had a nice fire and everything was dry and comfortable.

"You are dry, my grandmother. Why are you not wet?" "Hä hä hä," she laughed, "now I see you close even if I am ugly." "You are dry, my grandmother." "I'm not your mother's mother." "What are you then? My father's mother?" "No." "Are you my younger sister?" "No." "Are you my daughter?" "No."

He got up. He looked back as he was going out. One parting question, "Are you my wife? What are you to me?"

Toad jumped up and landed above the Chief's nose right between his eyes. He tried to pull her off but the skin stretched. He said to the people, "Come, get this toad off me." They came to help him. They tried to cut off the toad with a knife, but to no avail.

Coyote cried. "All right, let's talk this over."

They came together for a council. Coyote addressed the meeting, "We ought to have a sun. At night we ought to have a moon. I'll be the moon myself." 
Robin said, "I'll be the sun."

At night whenever anyone did anything Coyote announced the act to all the people. In the daytime the sun came up. It was so hot the people did nothing but swim. The Chief said, "'It is too hot. It isn't right to do nothing but swim. And Coyote is too utterly no good. He spies on everything we do."

They pulled Coyote down and threw him away. Robin was too hot so she suffered the same fate.

Then said Chief Child of the Root, "I will be the moon. I'll go far off so you can't see the toad on my face very well."

Helldiver's child who has only one eye said, "I'll be a good sun for you because I can't see so plain. I will not be too light or hot."' "All right."

So the road ends.

Stories of the transformer are told by tribes everywhere. In the territory covered by this analysis the role is frequently assigned to Moon or Coyote or the four transformer brothers, less frequently but nevertheless commonly enough for special recognition, to Child of the Root. In the majority of examples close attention is paid to the transformer's origin, little is told of his specific work beyond the generalization that he went about transforming people, and there are vagueness and uncertainty about his end. Any careful details are almost exclusively restricted to his entrance into this world, after that is settled it is enough for him to disappear. This is in contrast to the treatment accorded the Coeur d'Alene Child of the Root, whose work for mankind is clearly outlined and who, when it is finished, definitely takes his place in the sky as the moon.

Thompson versions are typical examples of this formal difference:

A girl marries hogfennel root and gives birth to a son; the boy is abused and taunted on his origin by the other children; his mother acknowledges his origin to him; he leaves and trains in the mountains; he travels about, sometimes in company with the Qwoqtqwal brothers, transforming bad people; roots grow wherever he goes; he leaves many springs behind; it is not known what became of him (MAFLS 6:45; MAM 12:319).

The Transformer learns the identity of his real father from a bird; the root confirms it; he transforms his mother into a stone for deceiving him and puts an end to intercourse with roots; equipped with great power, he sets out on travels and disappears; he will return with Coyote as chief and judge at the time when the dead come back (MAFLS 11:15).

${ }^{1}$ When the sun is not too bright Helldiver with only one eye can be seen on its face. 
A girl has connection with a root and gives birth to a son; the boy transforms a companion into a flat-headed fish for calling him the son of a root; he throws his mother into a lake for lying to him about his origin; he leaves and travels about transforming people; he disappears; it is said he went up to heaven (MAFLS $6: 95$; BAAS $69: 564$; ARBAE $31: 616)$.

A Lillooet version adds a few details to this Thompson account, but they are again largely linked up with the question of the root child's origin, rather than with his work or end. The boy transforms the father of the children who taunt him into a catfish; the people who mocked him into the grizzly bear, wolf, marten, birds and fish; when he travels hogfennel roots twine about his legs; everything starts burning when he stops the sun, so he makes it move again (MAM 4:350; ARBAE $31: 617$ ).

A fourth Thompson version, as well as a Sanpoil story (JAFL 46: 136), are notable exceptions to this generalizing tendency at the conclusion of the myth-though both Thompson and Sanpoil are still sufficiently vague in the body of it-and these two versions as a result become the closest parallels to the Coeur d'Alene myth taken as a whole.

A mother lies to her son three times about his father; the boy leaves; hogfennel plants wrap themselves about his legs; Bullhead Catfish calls him by his root name; he transforms Bullhead into a catfish; he kills his mother and puts an end to intercourse with roots; he travels about doing wonderful things; four mornings he wakes up with a wet belly; an investigation reveals Frog, who wishes to marry him, has been sleeping with him; a prettier wife is given him; Frog jumps on his face; Coyote as moon tells everything he sees; Child of Hogfennel becomes moon (Thompson MAM $12: 224$; ARBAE $31: 616$ ).

A woman throws roots under the ashes in the fireplace to obtain a brother for her first-born, One Eye, who originated from a chip in a cradle; she discards the first child, a girl, and receives a boy from the roots; the brothers reach the gathering of people assembled to change the sun; Toad causes a great rain so that the brothers will take shelter in her lodge; she jumps on the younger brother's cheek; One Eye and his younger brother become the sun and moon after Woodpecker, Crane and Coyote prove unsatisfactory (Sanpoil JAFL 46:136).

The remaining references to the root child are all of the typical brief unorientated type with no transforming details; the child, in fact, need not be a transformer.

The Shuswap tell of a boy who was said to be the offspring of the hogfennel root; he went about with the four transformer brothers ridding the country of evil beings. Some say the women had hogfennel roots for husbands before Coyote came and changed things (MAM $4: 644,652$ ). 
The Tlingit narrate that girls are warned they might have a baby from swallowing the sap of roots, for Root Stump formerly crossed canyons by striking his roots into the ground. Root Stump's origin is described as follows: all but a woman and her daughter are carried up to the sky by something which dropped down; the girl swallows root sap and gives birth to Root Stump; Root Stump pulls the malicious thing down from the sky by running his roots into the ground; he likewise kills a man who entices people into his canoe to kill them (BBAE 39:42, 193; ARBAE $31: 946$ ).

In a Haida myth the one girl left behind when the rest of the people are carried off by a feather eats roots and gives birth to a tree-spirit who seizes the feather while his roots hold him in the ground (MAM 14:642; MAM 12:228).

Though each of the above myths on the whole fails to mention the specific work of the hero, duplications of two of the feats accomplished by the Coeur d'Alene Chief Child of the Root are to be found in stories centering about the lives of other transformers, Moon, Coyote and others.

The service to mankind most frequently accredited to all the transformers alike is the abolition of man-eating awls, combs, etc.

This is a part of Moon's work in a Southern Puget Sound transformer myth. Crane (Wren; Blue Heron) is obliged to use his head for a hammer, since sticks and stones attack him when he picks them up; Moon transforms poles and stones into inanimate objects (he teaches Wren the use of the wedge and the maul). A parallel to Child of the Root's kindness towards Kingfisher or Fishhawk is Moon's act of stretching Crane's bill and legs so he can spear salmon in the water (UWPA $3: 77,81$ ).

In the Upper Chehalis transformer story Moon is attacked by a needle on the trail; he sticks a cattail through its eye and decrees it shall be used for sewing; when another thing tries to run over him, he decrees it shall be a mat-smoother (MAFLS $27: 164$ ).

In a Thompson myth Coyote is attacked by a comb, an awl, fine stones (for smoothing arrows) and a stone hammer, each of which he attempts to pick up in an underground lodge; he runs away and declares each shall henceforth be a tool for man's use (MAFLS 11:5).

In the Thompson version of Coyote's theft of his son's wife Coyote's son enters an underground lodge in the sky country, is attacked by a whole row of baskets when he tries to pick one up, replaces it, goes outside and curses baskets, making them henceforth servants of the people; the same thing happens to mats, awls, combs, and birchbark vessels (MAFLS 6:22; MAM 12:205).

In Shuswap stories of the Coyote cycle Coyote makes no decree with regard to the future rôle of the objects, but it may be that such action against them is implied: Coyote hears voices in a house, enters and hurls to the ground a hair and a comb, which are doing the talking (IS 8). 
Coyote seizes one of a row of snowshoes which stand on end around the walls of a house and dance when his back is turned; he is attacked by the snowshoes and runs away (MAM $4: 628$ ).

Among the Takelma Dragonfly, the Transformer, is attacked by a salmon-spear when he takes some of the provisions he finds in a house; he breaks the spear and declares it shall be an inanimate object in the future (UPMAP 2:39; ARBAE $31: 703$ ).

The trickster Raven's experiences with the Shadow people are not episodes in a transformer cycle; they include however references to such live objects as transformers have been found above to render inanimate.

When Raven starts to carry slices of halibut and seal out of a house, wedges throw themselves at him until he drops the meat; when he attempts the same thing in a second house where he sees only a design on the wall, appearing as if drawn with a fingernail, his hair is pulled; the Shadow people are attacking him (Tlingit BBAE 29:134).

Raven eats in the house of the shadows and feathers; he leaves; he returns to take away some of the provisions stored in the house; the shadows and feathers beat him and throw him out (Tlingit IS 316, 326).

Another form of Chief Child of the Root's work as a transformer reappears in part in a number of stories, his transformation of such individuals as Kingfisher and Fishhawk.

The closest parallel, Moon's efforts in behalf of Crane in Southern Puget Sound mythology, has already been mentioned.

In a Squamish myth a man rubs his double-pronged spear against fish and thus collects their slime; the Transformers show him how to spear salmon properly; he resents their kindness; they inject the two halves of his spear into his legs, push its point up his nose, stretch his neck and clap; he turns into a crane (BAAS $70: 519$; ARBAE $31: 606)$.

In Thompson, Lillooet, and Stsee'lis myths there is no transformation as such by the transformer: a man (sandpiper) rubs a sharpened pole (two sticks; the frame of a dip-net) against fish, then scrapes off the fish-slime and boils it (with grass or roots and berries); the Transformer shows him how to make and use a dip-net (a salmon-spear and fish-caches) and how to split, cook, and dry the fish (MAM 12:318, 349; MAM 4:294; ARBAE 31:605; JAI 34:362; ARBAE $31: 605)$.

A Newettee incident combines a feature of Chief Child of the Root's dealings with Splinter Leg with an element found in his treatment of Kingfisher and Fishhawk; the dominating motive, however, is one of revenge and punishment rather than of reward: The Transformer swims off as a fish with Crane's harpoon-point; 
he appears before Crane wearing it as an ear ornament; Crane recognizes it and puts splintered bone in the Transformer's food; he shakes the bones out of the Transformer's throat when the latter promises to return the harpoon-point; the Transformer presses the points into Crane's nose and transforms him into a crane (IS 201).

The selection of a moon and a sun is the concern of the people in a number of myths. The method of procedure and the factors which determine the choice are practically identical in all the instances; the variations which occur rest in the final identity of the characters chosen. As the Coeur d'Alene assign the moon rôle to Chief Child of the Root, so those tribes which have Moon as the transformer hero make him their choice with his wife (or grandmother) Frog (or Toad) appearing upon his face. In each of these instances Moon's younger, cross-eyed brother who has a rôle in his myth is appropriately enough accepted as the sun. In the Coeur d'Alene myth there is no character available for this part, for Child of the Root has no brother and no companions; it is stated that Helldiver's child offered to be the sun and was accepted. As will be noted in the list of tribes below, in whose mythology this creation episode is found, choices for a sun may include: Lynx's son, Coyote's son, Chicken Hawk, Redshafted Flicker's egg.

Southern Puget Sound. Yellowhammer, Raven, Coyote, Woodpecker, and Hummingbird are all unsatisfactory as the sun; Moon is too hot; Moon, with Grandmother Toad upon his face, becomes the moon, his younger brother becomes the sun (UWPA $3: 78,80$ ).

Coast Salish. Meon (the older boy who had been lost) rises as the day moon but burns everything up; his brother is frightened as the night moon (does not give enough light); thus Moon becomes the moon, his brother, the sun; Moon's wife (grandmother) Toad (Frog) is with him (both the moon and the sun have their Frog wives with them to doctor them when they get sick; Moon has on a tight cap which gives him cross-eyes like his brother). In the Cowlitz tale-the transformer runs away ashamed when the people discover that he eats too much; he becomes the moon; his wife jumps into his eye; his younger brother follows him and becomes the sun (MAFLS $27: 379 ; 172,176,271,272,283,360,378$ ).

Nez Percé. Coyote calls a council to consider the question of the sun and requests both of Sun's wives to attend, though Sun does not love the one, Frog; Frog sits on Sun's eye and cannot be dislodged; Sun is scolded for giving too much heat and is instructed to change places with Moon (MAFLS $11: 195$ ).

Kutenai. Raven, Chicken Hawk and Coyote are unsatisfactory as the sun; a woman's older child is chosen to be the sun, the younger child, the moon; Raven and Coyote (the Transformer, Coyote, and Chicken Hawk) are unsatisfactory as the sun; the two Lynx children are chosen to be the sun and the moon (Coyote, angry that he cannot be the sun, tries to shoot it; his bow catches fire and ignites 
the prairie; he escapes burning by lying in the trail) ; Coyote is unsatisfactory as the sun; Chicken Hawk is found acceptable (BBAE 59:67, 117, 287; ARBAE 31 :728; VBGA $23: 161$; Dyer).

Okanagon. Red-headed Woodpecker, Crane and Coyote are unsatisfactory as the sun; Coyote's son is chosen (JAI $41: 145$; ARBAE 31 :727).

Shuswap. Many birds and Coyote prove unsatisfactory as the sun: a red bird meets with approval; Coyote is unsatisfactory as the sun; Redshafted Flicker takes his place; Flicker later lays an egg which is changed into the present sun (IS 5; MAM 4:738; ARBAE $31: 945$ ).

Incidentally in a Wishram myth Coyote tries out for the position of Sun Woman's slave; as usual he gossips about everything he sees; Sun tells him he is too mean for her to take about any longer (PAES 2:47; ARBAE $31: 945$ ).

Additional Shuswap and Thompson stories, though they do not discuss the actual selection of a moon, explain the presence of a woman upon it.

Moon pettishly tells one of his wives who has borne him two children and of whom he is less fond than the other, to camp on his face; she is still there (holding her birchbark buckets and snow-shovel) (Shuswap: MAM 4:653; IS 15).

Moon invites the stars to his house; the Pleiades crowd the house; Moon jokingly tells his sister to sit on his face; she is still there holding her water-buckets (Thompson MAFLS 6:91; MAM 12:229).

\section{B. COYOTE CYCLE}

\section{Origin of Indian Tribes (From Parts of Monster)}

Grizzly tries to kill Rabbit for his food

Rabbit tricks Grizzly in contests

Rabbit kills Gobbler's wife

Coyote hides Rabbit

Coyote's powers help him defeat Gobbler and his dog

Coyote frees people in Gobbler's stomach

Coyote cuts up Gobbler, throws his parts about and the Indian tribes originate

Rabbit had a house near Grizzly Bear's. Grizzly was always starving and Rabbit always had to feed him. Besides eating all he wished Grizzly always wanted to take some food along with him. Then he became so greedy he thought he would kill Rabbit and get all the food. "Let's play," he proposed. Rabbit said, "We are no children to be playing." "Oh, come on, let's play. Let's go bathing." 
When they were in the water Grizzly said, "Let's splash. Let me be first." He took water and threw it at Rabbit, then laughted, "Uh uh uh !" Rabbit took a big spoon made of elk antler. While Grizzly was laughing he filled it with water and threw it down Grizzly's throat. $\mathrm{He}$ almost choked. Rabbit ran away into his house. He threw Grizzly's food out at him and saw him eat it greedily. Grizzly laughed again, "We are only playing." "I'm going to shoot him in the eye," he added to himself.

Rabbit took a bladder, blew it up and put it in his eye. Grizzly shot at him, the bladder burst. Grizzly laughed, "My! Isn't that fun !" Then came Rabbit's turn. He shot and put out Grizzly's eye. He growled. Rabbit ran home. Then he ran into the timber and soon came to the house where a wicked old woman lived with her daughter and son-inlaw. The husband of the girl was gone. Rabbit killed the girl. He took a knife and began to skin her. [As he did so he asked the old woman, "Are my ears getting longer?" "Yes." Then as he cut her down the back, "Is my fat showing?" "Yes," the old woman was compelled to answer.

The girl had an understanding with her husband when they first got married. She had told him, "If one of your arrows breaks when you are hunting then you will know I am dead." He had told her, "If ever your digging stick breaks when you are digging camas you will know I am dead."

Now when the husband was out hunting he was warned of his wife's disaster by the breaking of his arrow. He hurried home. "Mother-inlaw, what does this mean?" he asked. "Rabbit came in, killed our daughter, cut her open and went away again." ${ }^{1}$

Rabbit had escaped into the timber but the man came after him. Rabbit made all kinds of tracks in the timber so the man could not track him easily, but nevertheless he followed. Then Rabbit put cooked camas down at intervals. This was so the man would be delayed by picking it up to eat. Finally Rabbit came to the open prairie. Just as he got a good start forward he ran into Coyote. He said, "You shouldn't delay me this way. A monster is chasing me."

Coyote took up some jointgrass, pulled the joints apart and hid Rabbit in it. When he looked at Rabbit he was shaking with fear. Coyote blew the jointgrass so it looked as if it was shaking in the wind. Then he consulted his powers. The first one said, "The monster who is after you has a dog, the Grizzly Bear, whose name is tcn'aqsi'na. I'll be your dog and my name will be the same. I'll be very small." The second

\footnotetext{
${ }^{1}$ The part in brackets was not given in the text, but was explained by the informant.
} 
power said, "I'll be a knife at the back of your dog' head." The third said, "I'll give you the power to gobble everything up."

They saw Gobbler coming with his dog. "Did you see what I am chasing?" he asked roughly. "What are you chasing?" "A rabbit." "No." "Here are his tracks." "No, I didn't see him. Maybe he passed before I came." "Hum, hum," growled Gobbler's dog. "Be quiet, tcn'aqsi'na!" said Coyote. "Why! We call our pets by the same name!" said the monster."

Coyote answered, "Ah, ah, my father and his father, then his father and his father had the same name for their dogs." Then the monster became angry. He walked toward his pet. He said, "Make your pet stop growling, we might kill you." Coyote said, "You stop yours." "You better listen to me. He will kill you." Coyote laughed, "We might kill you." "Oh no!" Then Coyote proposed, "Let's have our dogs fight."

So they turned the dogs loose and they fought. Coyote's dog was bitten and stepped on. Coyote laughed. He called, "What is the matter with you, tcn'aqsi'na? Why don't you put your head under him?" and laughed again. Again he egged him on. Then the dog crawled under Grizzly and, with the knife behind his head, ripped his stomach open. $\mathrm{He}$ fell.

The monster mourned for his dog. Coyote said, "It's too bad. I told you to call off your dog when they started to fight. I saw they were mad." "Shut up! I'll gobble you up!" Coyote answered, "Do you mean you will gobble me up? I'll gobble you up! Let's see if we can gobble up that tree. You try first!"

The giant tried, but left about three feet of the stump standing. Coyote laughed. "I thought you were smart. Now look at me!" $\mathrm{He}$ gobbled. When he was through not a splinter of the tree was left. "Now look," said Coyote. "That is the way real gobblers gobble. Let's go and gobble that cliff. You go first."

The ogre gobbled at it but when he had done his best some rocks were left. Coyote laughed. He gobbled and not a pebble was left. "You are not like me," he bragged, "I am the smart one!" "I might gobble you up," said Gobbler. "All right, try it !"

Before Coyote could look he found himself inside the monster's stomach. There were lots of people there playing games. Some were playing the stickgame, others cards, still others were dancing a war dance. Coyote said to them, "What's the matter with you all? You are pitiful. Don't you know you are in the belly of a monster. I am going out of here. Get yourselves ready. Soon I'll be back, then I'll fix it so you can come out." 
He tickled the ogre's heart and was spat out. Far away he landed. Coyote picked up a stick to make a hoop and continued making hoops as he talked to Gobbler. "Your insides show you are a good gambler. You are a card player." Coyote had made a hoop the size of the ogre's mouth and was now fashioning two smaller ones the size of his nostrils. "You are a good war dancer."

The ogre answered, "Because you are no good, that is the reason I vomited you up. I eat only good things." Coyote said, "You only think so. You eat mice. I am the one who eats really good things."

"Just a minute ago I got through eating two nice, neat, good-looking people." Coyote said, "I was the one who ate those two." "If that's true vomit them out." "Come," said Coyote. "Sit down there, close your eyes, I'll close mine and we will see what we can vomit. You do it first!"

The monster vomited two people and Coyote four mice. Coyote threw the mice in front of Gobbler and put the people on his side. "Hähui! Let's open our eyes." Coyote laughed. "Those nice-looking ones are the ones I ate." Gobbler could not believe his eyes. "They are the ones I ate. I never did eat mice." "Look where they are, on your side." "I'll gobble you up!" "You're a mouse-eater!" Coyote had the hoops in his hand. He held them flat. "All right, go on, gobble me up."

Again in a twinkling he was in the monster's stomach. "Hähui!" he said to the people. "Wait till I run out, then you can get out too."

He ripped open the stomach. It was light again. The people ran out. He cut off the giant's heart. Then he set the large hoop so it would hold the mouth open and the smaller ones in the nostrils. Everyone came out. The ogre died. Coyote ran off.

He went back to the jointgrass where Rabbit was hiding and took him out. He was glad to be free. Then Coyote told Rabbit to cut the giant up. He cut him all up. Coyote took the pieces and threw them about. He threw a leg and said, "You will become the Blackfoot Indians. You will be tall." He threw a rib saying, "You will be the Nez Percé. You will have good heads." 1 The paunch became the Gros Ventre, "You

${ }^{1}$ Referring to the fact that the Nez Percé have beautiful long hair. will have big bellies." Then he threw the heart. "You'll be the Coeur d'Alene. You'll be mean."

He threw all the pieces away. Then he wiped his hands on some grass. He threw the grass away. "You will be the Spokan. You will be poor," he decreed.

That is the end of my road. ${ }^{1}$

${ }^{1}$ Additional explanation not in the text: Each time a piece of Gobbler's body hit the ground smoke came up and made a dwelling. The Palous Indians were made of the second stomach. 
A similar myth is found among the Nez Percé, Sahaptin, Wishram, Wasco, Thompson, Kutenai, Shuswap, Chinook, Kathlamet, Southern Puget Sound people, Sanpoil and Corvlitz.

The Nez Percé (CUCA $25: 26$ ), Sahaptin (MAFLS $11: 148-9$ ) and Wishram (PAES 2:43) myths and a Thompson version (MAM 12:314) correspond to the second half of the Coeur d'Alene myth: Coyote kills a swallowing monster, frees the people inside it, carves and distributes it.

Other instances of the dissection and distribution of monsters are frequent, although there is little agreement as to the ultimate disposition of the body parts and the sources of origin of the various tribes.

The animals kill, cut up and distribute the water monster which had swallowed Flicker and Duck (Kutenai BBAE 59:81). Chief Woodpecker kills and, assisted by the animals and birds, cuts up and distributes Seacow who had hit Big Woodpecker's brother and made his head bloody (Kutenai, Dyer). Bluejay scatters the parts of the water mystery monster he has killed (Shuswap MAM 4:667). The crying monster is distributed by the men who killed it (Thompson MAFLS 6:79). Ntci'mka has his boy helper scatter the body parts of the man-eater they have killed (Thompson MAFLS 6:81; MAM 12:255). In Chinook mythology (BBAE $20: 21)$ two transformers and their dog defeat a monster woman and her dog in contests, revive the boys she has killed, hurl her down a precipice and instruct the boys to scatter her body parts in various directions. In the Kathlamet myth (BBAE $26: 65$ ) the youngest of five brothers allows himself to be swallowed by an elk monster, kills it with the help of his dog and his grandmother and cuts it up; the pieces of elkskin become prairies.

Additional myths which recount the killing of monsters omit the distribution and tribal origin element.

With the help of his excrement Coyote and his dog defeat Cannibal and his dog in contests (vomiting and dogfight); in exchange for his dog of dung Coyote receives Cannibal's staff for calling the deer (Thompson MAFLS 6:30, 81). Coyote, swallowed by a monster, kills it with the help of his two sisters, the Cayuse girls, pieces of excrement, and the people inside are exhaled (Wasco PAES 2:267). Xode tricks Mountain Woman in a vomiting contest, is sucked in by her and transforms her into a rock (Southern Puget Sound UWPA 3:120-1). Coyote tricks man-eating Owl in a vomiting contest; Coyote and Owl turn into cliffs (Shuswap IS 9). Elsewhere Coyote transforms Cannibal Owl into an owl (Thompson MAM 12:300). In the Sanpoil myth (JAFL 46:160) Coyote's dog kills the monster Grizzly Bear; Grizzly Bear kills Coyote, Fox revives Coyote, Coyote's faeces become his dog and flint and kill Grizzly. The Cowlitz (MAFLS 27:260) relate the myth of Xwáni and his dog: Xwáni takes out his excrement sisters who warn him of the dangerous being and his dog. Xwáni changes his excrement into people and a dog; trades dogs; the dangerous being slips on the excrement people and is killed. 


\section{Coyote Overpowers Sun (Securing Sun Disk)}

Coyote's four children and Antelope's four children steal sun disk

Coyote's children killed

Coyote steals disk from Antelope

Antelope recover disk

Coyote seeks revenge

Meadowlark advises Coyote to travel at night

Coyote's powers help him in contest with Sun at a spring

Coyote overcomes Sun

Coyote restores Sun's light

Coyote and Antelope lived together. Each had four children. The Coyote children had names, the Antelope children had none. Every morning Coyote's children went into the sweathouse. Antelope's children went away. In four days they returned. Then Coyote's children went away and Antelope's children went into the sweathouse to sweat. They did that for a month. Then they all went far away. They came to a place where there were many people. At night the oldest Coyote stopped nearest the people. Then the second, the third, and finally, the youngest took up his place. That was all of Coyote's sons. Then the oldest Antelope took his place and the others arranged themselves in order according to age.

Sun, who was chief of the people, had a valuable disk the Antelopes and Coyote wanted. It lay in the chief's house. Coyote's child went in and took it. When the people found it was gone they cried out. They gave chase and just as they were about to kill him he rolled it to his next younger brother. In this way each Coyote got it and passed it to the next although he was killed in doing so. The oldest Coyote passed it to the oldest Antelope. Each Antelope passed it to his brother and all escaped for they could outrun the Sun's people.

The Antelopes went home and announced ${ }^{1}$ that the Coyote children were dead, "You no longer have any children, Coyote!"

Coyote and Antelope had been listening for the return of their children. Now they heard the cry of mourning. They went out and listened, "Oh! You have no children any more, Coyote." Antelope said, "They said, 'Coyote?" "No," said Coyote, "They said, 'Antelope!" As they were arguing the same cry came again. Each insisted it was announcing the misfortune of the other.

Finally Antelope said, "My children are not lazy enough to be killed."

Coyote retaliated, "Are they not my children who go to rocky places and eat nothing but rosehips for four days at a time?"

Then Antelope put a stick in the fire and when it was well burned

1 This they did by hammering on their canoes, then the people came out of their houses to hear who had died. 
hit Coyote making marks around his eyes. Coyote burned a stick and just as Antelope ran out hit him with it at the root of his tail and on his legs.

Coyote left Antelope's house. He cried all the time. Then Antelope said to his children, "Whenever he stops crying give him the sun's disk. His children are the ones who really got it."

Coyote kept on crying. He did not even sleep for about four days. By that time his cry, "äwäwä, äwäwä, my children," had become very faint. Antelope said, "Go and see." Some went. They pulled aside the rush mat which served as a curtain and saw nothing. The crying continued weakly. They looked around for Coyote and found that he had left long before. He had left his spittle crying in the fire.

When the antelope came out looking for Coyote they saw him running with the precious disk. They followed him to the cliff over which Spokane Falls play. When Coyote got there he said, "Four times I will pretend to throw it over the cliff. The fourth time I will really throw it into the river." Each time he raised it he sang, "The precious disk, wu...," but he did not let it go. After three times he said, "Only once more then I'll let you go. Then you'll stay for good."

Meanwhile the antelopes were coming nearer. Just as he let it go, one caught it exclaiming, "How can you ever pay for it?" Coyote answered, "What did you pay for it when you had it, this valuable thing?" The Antelope took it.

Coyote kept on crying. He went home. He did not eat or sleep, just cried for some days. One day at sunset he stopped crying and said, "u-u-u !" Antelope said, "You smarty of a Coyote!"

Then Coyote sang:

“xiyä xiyä wä wä xu xu lä

"I ought not to be a woman.

"Why should I soil my eyes with crying.

"Go and sing, my aunties."

"Maybe he didn't die, the one who said that to me. Maybe you are just like me. Now I am going to avenge my children." Antelope said again, "That smarty of a Coyote!"

Coyote went. All night he serenaded his aunties, the little mice. Just about daylight he said to his aunties, "In just a month after I have gone you will think me dead." As he went out, he said, "Good day, my aunties," and left. He walked and walked. He thought by walking east he would get to where the sun was. In broad daylight he walked. The sun saw him and said, "You sly one! You think you are going to take revenge and you are walking in plain sight." 
Each day this happened. One day Coyote saw two nicely smoothed little sticks in the road. He stepped on them. They broke. "änininin! You broke my leg. I was going to tell you a story."

Coyote answered, "I have business to attend to now." "What do you have to worry so about?" "Oh, go on tell me a story. I will fix it for you."

He put the bones in place and smoothed them. Then said Meadowlark (for it was her leg he had broken), "Why do you go around in the daytime when the sun is out? He can see you walking around. Don't walk any more in the daytime but only at night. At daylight lie down in a hole in the ground and sleep. About sunset get up and walk." Coyote said, "Thank you."

He rewarded meadowlark by putting around her neck a black medal on a black string which had belonged to bluebird. Now Coyote traveled only at night. At dawn he lay down until the sun was gone. The sun wondered, "I wonder where he is. Maybe he is lying down."

Then Coyote saw the spring where the sun paused to drink every day at noon. He consulted his magic powers." "Tell me what to do right away." They said, "He never passes by that spring without stopping. Always at noon he stops to drink."

Coyote went over to the spring. He saw two holes where the sun placed his knees as he bent to drink. His powers told him, "Opposite those holes dig two for yourself. At dinner time when he comes down he will stop here. He will descend but will not touch the ground. Don't attack him until he comes down."

One power gave him a small knife like a paring knife. The other gave him something to shoot with. The third was to hold him back when the sun pretended he was coming to earth.

The next day the sun rose. He said, "Coyote, whoever seeks revenge must lie down." Coyote said, "He saw me already, I may as well be walking," but his powers said, "No he is only pretending. After a little he will come down closer." Coyote saw something hanging down from the sun's head. His powers said, "That is his heart. That is what you must cut off."

Up again went the sun. "Let me get him," said Coyote. "No, he'1l soon come very close," and his power held him back. Once more it came down, "I am going to shoot at it."

"No, you would only shoot in vain. He would not die. You must cut off his bangs. Only then will he die." The next time the sun touched

\footnotetext{
${ }^{1}$ I was not able to find out just what these powers were. There were said to be four of them, I suspect they were Coyote's penis, testes and dung, or they might have been only dung. In Thompson mythology Coyote's power is his excrement (cp. MAFLS $6: 30$; also BBAE $26: 45$, BBAE $20: 92$ ).
} 
the ground. He looked around, there was the water. He reached across the spring and supported himself, then drank. Right there Coyote was lying near the sun's heart. His power said, "Grab it!" He pulled it, bit it. One power handed him the little knife and said, "Cut it!" He cut it. Then Sun fell down and died. It became dark. Then all the Lndians said, "Now Coyote has murdered someone."

Coyote went off. He went far, far. He stumbled over Sun. He felt around. "This is the one I killed." Every time he stepped he stumbled over the body it was so dark. Again he asked his powers what to do. They said, "Put down that thing you are holding in your hand." He put it down. It became light, it became light.

Similar myths are found in the mythology of the Shuswap, Thompson, Wishram, Kutenai and Coast Salish:

The Shuswap and Thompson versions correspond closely with the Coeur d'Alene story up to the point where Coyote escapes from the antelope with the disk, which is described as a "glittering ball." Here Coyote turns into an elk, uses fragments of the ball as armor and kills many people, until Meadowlark intervenes; Coyote avenged makes his escape (MAM 4:642; MAFLS 6:32; MAM 4:313).

In the Wishram myth Antelope's two sons succeed in stealing the people's shinny ball, while Coyote's four sons and one daughter are killed; Coyote with the aid of his two faeces catches the Antelope and transforms them into antelope (PAES $2: 67)$.

In the Kutenai version Young Coyote is captured while stealing the people's hoop, but his companion, Young Fox, rolls it home safely; Old Coyote and Fox in turn free Young Coyote. Subsequently Coyote and Young Fox lose the hoop in gambling with Salmon; Fox and Young Coyote win it back (BBAE 59:143 and cp. this work, tale 12).

In an Upper Chehalis myth Stehe'n's grandchild escapes with the people's shining hoop and shares it with his grandfather; the five Fox children are killed (MAFLS 27:70). In the Skokomish version Stuhe'n's grandson is victorious (MAFLS 27:369); in the Wynoochee Stahe'n's grandchild wins from Coyote's four sons (MAFLS 27:345); and in the case of the Cowlitz Coyote Boy obtains the shining hoop although Coyote's five sons are killed; Coyote takes the hoop up to the sky as the sun (MAFLS $27: 230,231$ ). The Cowlitz version is the first instance of the identification of the stolen shining object as the sun, the Coeur d'Alene interpretation.

A parallel to the Coeur d'Alene episode of Coyote's contest at the spring with a power of light is found in myths of Sahaptin and $\mathrm{Nez}$ Percé origin which have a different motivation:

Moon's son kills people for his father to eat; Coyote kills Moon's son while he is drinking at the spring and places Moon in the sky (MAFLS 11:173-4). 


\section{Coyote Steals his Daughter-in-law}

Coyote's son has two wives, Black Swan and Tern; Coyote covets Tern

Coyote with help of powers gets his son into the sky

Coyote marries Tern

Coyote's son encounters spiders

Coyote's son kills father of his Beaver wives, revives him

Coyote's son becomes homesick for Black Swan and his child

Spider Women provide box for his return to earth

Coyote's son finds Black Swan far from camp and hides in her pack

Coyote's son kills all the people except Black Swan and her child

Coyote had a house. He had a son who had two wives. One was Tern, the other was Black Swan. ${ }^{1}$ The latter had a baby. Tern had none. Everyone liked Swan, no one liked Tern. Coyote thought, "I'll be the one to fall in love with Tern. Black Swan is really black and ugly. I must find some way to do away with my son, then I can have Tern for myself."

He went off and consulted his powers. "What can I do so that my son will die?" "Take him up to the sky," said one power. "I will be something good to climb up on," said the second. The third said, "On the tip of that tree I will be an eagle's nest in which there are two desirable small eagles." The fourth said, "Keep arching your brows so he ascends." "All right," said Coyote and went back home. He said to his son, "I see two eagles have a nest in the top of the pine tree. It would be nice to climb up for them." He answered, "Yes, I'll go in the morning." Coyote said, "All right, in the morning we'll go for them."

They went. They saw the young eagles were just about large enough to fly. The boy climbed up. He looked down and saw his father lying on his back and raising his eyebrows. "Why are you doing that?" he asked. "I am afraid you might fall. I don't mean to do it but I can't help it I am so worried."

He really did it because it made his son rise higher each time. The son rose higher and higher and finally went right into the sky. Coyote got up and went back into his son's house. He said to Black Swan, "Go far away. Your husband left because of you." Thus he sent her away.

He said to his children, "Your older brother has gone up. You will never see him again." Then he took Tern for his own wife.

The son found the sky just like the earth. He saw an elk and shot it. He butchered it and dried the meat. At night when he was trying to sleep he heard people talking. He understood one to say, "You must have seen that person. You defecate on people so you can eat." The

${ }^{1}$ The Coeur d'Alene say that long ago black swans were numerous in their country. 
other answered, "You must have seen an elk. I suppose you would defecate on him so you can eat." The older of the two brothers ate game, the younger ate people. (They may have killed them by defecating on them.)

Each one of these people had a cane on which was tied a bone of each individual he had killed. One cane had elk bones, the other had human bones. Then he heard them fight with canes. One was poking the other into the ground with a cane. Coyote's son arrived there. The older was a spiderlike animal with very long legs who said to Coyote's son, "My younger brother, gave me that elk over there. I will protect you. Go take everything that is good. He will covet it. When I get there we will fight. Just as I catch hold you must say, 'Chop my leg off, my daughter's child.' Take a stick and put it by your leg. Then I will say to you, 'Chop my leg!' Then run around as if it hurt. I will say it again and this time we will really chop his leg."

So the spider ran and ate the meat. His companion was jealous of him. Coyote's son went off. He stood under a tree. It was raining hard. He put his quiver under his blanket to keep it dry. He heard women laughing, "hä hä hä, Beaver's older sister is going down creek, hä hä hä, Beaver's younger sister is going up creek."' He heard "p'atcetcetce," the sound of beaver being clubbed with a stick. They said, "Oh! He is wet, our husband."

They came straight toward Coyote's son and stood on the opposite side of the tree. Then they said, "Go! You are wet. Let's go now." There were four women beavers and each was carrying two beavers. Coyote's son went with them. They came to a house and all went in. The women were beavers and they all ate beaver.

The next day Coyote's son went hunting. He shot a deer and went on looking for another. He shot the second but when he had butchered it and returned for the first it was gone. There was nothing but blood sprinkled over the ground. He came back to the house, "Ah! He killed a deer, our husband. Ah! Ah!"

The beaver woman were glad to have the deer. He said, "I killed two but when I came back for the first it was gone." They said nothing but smiled.

The next day he went again. After he had shot the first deer he hid to watch it. Soon Long Legs came. He could see that Long Legs' body was small and round. He cut up the deer and ate it. Coyote's son shot him and he died. He shot a second deer and took it home. The women were very quiet, it looked as if they had been crying. They would not cook the deer so he cooked it himself. He took off his moccasins. $\mathrm{He}$

${ }^{1} \mathrm{~A}$ common Coeur d'Alene saying which indicates that something important is about to happen. 
offered them something to eat. Just one ate with him. The rest turned their backs. He said, "I killed that long-legged fellow, the one with the small head."

Then the women burst out crying, "It was our father you killed," they said. "Why didn't you tell me? I told you something ate my kill. You didn't say a word. Why didn't you say, 'It is our father?' Stop crying now. He will live again."

He put on his moccasins, dressed himself and went out.' He found Long Legs all sprawled out. He stepped over him. Slowly he got up. "Hä hä, my son-in-law," he said. "When I said something had eaten my kill your children did not tell me it was you." "Hä, didn't you know I saved you that time you killed the elk. You were just going to be eaten by Spider's brother but I saved you. Now I am going. Follow me."

They went hunting. They killed many deer. When they came home the women were happy again. This time they cooked. "You should have told me that was your father. I would not have killed him," said Coyote's son again.

The next day when he went hunting he killed two deer but left one for his father-in-law. Although he had children with the beaver women he began to be homesick for Black Swan and her child. He lay down and covered himself with his blanket. The children came to play in his lap. "Don't do that," said the women, "there's a hole in his moccasin near the big toe. ${ }^{1}$ Your father is homesick for Black Swan."

$\mathrm{He}$ got up and went out. He wondered what to do to get back to Black Swan again. He went far. He came to a house where he heard someone talking, "Ludidi, ludidi!" He went in. An old woman sat on each side of the fire. They were feeling around on the floor and arguing, "Ludidi, it is mine." "Ludidi, no, it started on my side."

They were talking about a stalk of hemp grass which grew underground from the side of one to the other. Coyote's son said, "You are my father's mothers. Show me how to get back." They remained silent. He said, "I'll pay you all my clothes." They did not even look at him. They kept on spinning. He said, "I'll give each of you a sack of meat." They paid no attention. "I'll give you hemp." Then they said, "You are our grandson." "I have been trying to talk to you a long time." "You talk as if we wore clothes. This rope stuff is what interests us." $\mathrm{He}$ said to them, "Is it all in one piece? There is just one measure for each of you."

They took a box and put him in it. It had a lid. They directed him, "Four times you will stop before you get to earth. When you get to land

${ }^{1}$ An unkind expression signifying jealousy because a man is longing for another woman. 
you will hear grass blowing. Then get out. Every time you stop before that roll around, then the box will start again. Every time it falls, close the lid again."

The box started to fall. It stopped. He rolled from side to side and it fell again. ${ }^{1}$ Four times this happened. Then it reached the earth. Coyote's son heard grass blowing. He opened the box. There was the earth. $\mathrm{He}$ got out, put the lid on the box, pulled the spider rope and it went up again. He walked away. "There's where our house used to be. It's gone now."

He saw traces of his father's camp. Near it he made a little fire. He saw the people when they moved from there. His wife was carrying the house of reeds, and the baby sat on top of it. When he came near the baby looked back and said, "bä bä." It was baby talk for "papa." His mother said, "Long ago your father went to the sky." Nevertheless it kept on. Then she looked back and saw her husband. She said to him, "It is pitiful the way we are treated. Your father sent me away. He took Tern for his wife. He made me camp far away." Her husband said, "I am going to kill him."

She said, "Every time I come close to the camp he says, 'Go far!' Perhaps you saw how far my fire was from the people's camp." $\mathrm{He}$ said, "Carry me with your pack. When you get to his house set the house mats and me along with them against the wall of his house." "No, they will kill me." "Don't be afraid. Put me down and untie the pack quickly."

She obeyed him. When they came close the people told her to go far away. She kept coming closer. She put him down and untied the pack. Coyote said, "What do you mean by following us? Didn't we leave because of you?"

Slowly his son got up. Coyote saw him. Then he began to cry, "This is the way we take pity on your wife."

The son took a stick and clubbed Coyote, Tern, his brothers and his mother. His mother said, "It isn't my fault. I didn't want to treat her like that."

However he was merciless and he allowed only Black Swan and his child to live. The three lived there.

That is the end of the road.

This myth has a wide distribution. Each of the variants listed below, with the exception of those of the Thompson (MAFLS 6:21; MAM $12: 205,296$; IS 17), lacks the account of the young man's adventures in the sky; in the majority of cases he is marooned on a high rock until

${ }^{2}$ There is no indication of a taboo in this story. It is merely the way the spiders move, as Julia says, "Like an elevator," making four regular stops. 
help comes to him. Otherwise the myths are identical with that of the Coeur d'Alene except for minor variations.

Southern Puget Sound. Coyote's son's wives are two faithful mourning doves and two spawn of male salmon; Coyote's son takes back his wives; Coyote, shamed by his son, drifts downstream (UWPA $3: 147$ ).

Southern Puget Sound. Coyote's son's wives are two faithful ring doves and two sawbill ducks; Coyote's powers, who assist him in getting his son marooned, are identified as his sisters in his stomach, in the form of berries; when caught in the river, Coyote floats downstream, his two stolen wives become sawbill ducks (UWPA $3: 145$ ).

Sahaptin. Coyote's son's two wives are faithful Beetle and Duck; Coyote's son meets obstacles five times in his descent in a spoon lowered on ropes by the sky people; Duck becomes a duck; Old Coyote is shamed by his son (MAFLS 11:135, $137,138)$.

Nez Percé. Young Coyote's wives are faithful Black Cricket and White Swan; upon Young Coyote's return White Swan dives into the water to remain wild forever; Young Coyote becomes hunting chief again; he separates Coyote from home by five valleys; Coyote drifts downstream (CUCA 25:376).

Wasco. Eagle has four wives, two of whom are faithful to him; Old Thunder splits the rock on which Eagle is marooned; Eagle revenges himself on Old Coyote, who drifts down to the ocean (PAES $2: 264$ ).

Chilcotin. An old man is jealous of a young man's two wives (MAM 4:29).

Shuswap. Coyote's son (or nephew) has two (one) wives; Bush-tailed Rat and Mouse (Spider Woman and Mouse Woman) by singing reduce the size of the rock on which yourg Coyote is marooned; Coyote's son and his younger wife part company with his father (MAM $4: 622,737$ ).

Columbia River. Coyote's powers are identified as four small objects he carries under his arm; Coyote's son causes a flood in which his faithless, fair-skinned wife becomes a swan; Coyote floats downstream (Idaho Farmer, Aug. 7, 1930).

Cowlitz. Coyote's son has four wives, two with white legs whom Coyote covets; Coyote's son causes a flood in which his two faithless wives become mice; Coyote floats downstream (MAFLS 27 :243).

Thompson. Coyote's son has two wives, Loon and Mallard Duck; in the sky Coyote's son is attacked by baskets, mats, awls, combs, and birchbark vessels, each of which he reduces to harmless servants of man (cp. tale 1 of this work); he transforms two blind women (partridges) who insult him into a foolhen and a ruffed grouse; back on earth he collects all the deer for his faithful wife and himself while the other people starve; Raven's children are discovered quarreling over the fat which Raven obtained from him and the people return (cp. tale 9), they are restored to plenty; Coyote, tricked by his son, is carried downstream. 
The action continues into the tale of the Salmon Release (see tale 8) in the versions from Southern Puget Sound, Nez Percé, Wasco, Columbia River and Cowlitz. In the Ntlakyapanmq variant Coyote, adopted as a slave by four women, releases fog and wasps (IS 7).

The element of the individual's homesickness for the earth while he is in the sky country and his return home (accompanied by his sky relatives), usually through the medium of the spider's rope, common to the above myths, finds analogies in the following otherwise unrelated stories:

Wasco. The boy who married Sun's daughter (PAES $2: 306$ ).

Lower Fraser River. The children of Sun's daughter who wish to visit their great-grandparents (IS 40).

Kwakiutl. The wife of Food Giver (MAM 5:52).

Tlingit. A man and his wife carried off to the sky (BBAE 39:251).

Chilcotin. Two sisters flee to the sky to escape from their husband, Skunk (they are lowered in a basket by an old sky woman) (MAM $4: 29$ ).

In a Thompson myth Spider's thread is too weak to help a man down from the upper world to the world below to visit his brother and Crow advises the man in a dream to jump through a hole, roll over upon hitting an obstacle, and jump again, which the man is obliged to do four times before opening his eyes in the lower world (MAFLS 6:78).

An analogue to the sky encounters of Coyote's son is found in a Kathlamet story:

A boy in the sky meets a man-eater, Evening Star whose house is filled with human bones and eyes, and a mountain goat hunter, Morning Star with whom he stays as son-in-law until he becomes homesick and is lowered to earth with his family (BBAE $26: 13$ ).

In an Upper Chehalis myth a young man, who has escaped up a tree from his captor, Lion, climbs up to the sky, encounters Evening who kills deer and men for food, is rescued by Dawn's daughters and, accompanied by his family, is lowered to earth by Spider (MAFLS $27: 83$ ).

In Nez Percé mythology a man, offended by his brother, climbs a tree in pursuit of a pheasant; while his bear stands below winking, the tree grows ever taller, until the climber disappears into the sky (CUCA $25: 163$; cp. also Sahaptin MAFLS $11: 158)$. 
A Sanpoil myth opens with the Coeur d'Alene setting though the story is developed along different lines:

A younger brother, who covets his elder brother's wife, sends his older brother for eagle feathers and maroons him on a cliff; the older brother fastens eagles to himself which carry him to safety; he leaves his wife with his brother and goes to his uncle (JAFL 46:148).

A list of myths of the Coyote-Coyote's son cycle, extending over a wider territory than has been covered by this study, may be found in MAFLS $11: 120$, footnote 1 .

\section{Little Beaver}

Grizzly Bear with the help of false Coyote kills Coyote's four sons

Coyote adopts Little Beaver

Little Beaver is trained for revenge

Little Beaver kills Grizzly

Coyote's powers help him kill Grizzly's family

Coyote disguised as pestle seduces Grizzly's daughter

Coyote had a house. He had four children. The oldest went to visit Grizzly Bear who lived on a hill nearby. There was a Coyote who had turned against his own tribe and had made himself an ally of Grizzly Bear near whom he lived. Every time he saw someone coming he cried, "Go under the hill, not across the top." If they did so Grizzly could easily come out and capture them. He would then run out and claw and bite the visitor to death.

When the sorr of the true Coyote came to visit Grizzly gave him something so hard to eat that it made all his teeth come out. As he went home he followed the traitor's advice and went under the hill. Then Grizzly killed him. The same thing happened to Coyote's other three sons.

For a long time he mourned. Suddenly he stopped and went to the river where he sat down on the shore. In the water he saw a little beaver. He said to him, "Come over and stay with me because I am lonesome. Then I can see you around my place. Go ask your mother." Little Beaver paid no attention. Coyote said, "Do you hear?" but he did not answer.

Then he disappeared. Coyote started to cry and kept it up a long time. Then he went back to his house and lay down. Someone came in. It was Little Beaver's mother. Coyote was covered up with his blanket. She asked him, "Are you asleep?" "No." "You wanted my little one to come to live with you. I came over to talk over the matter with you." 
"Yes. I would like to have him. I can't help being so lonesome." "All right, he may come, but he is very greedy. You will have to chop trees for him to eat." "All right," said Coyote.

She went home and came back with an ax. Coyote began to chop. A tree fell. Before he could chop another Little Beaver had eaten it. All day long he chopped and he was never even a tree ahead. At night the Little Beaver played around in the house, and he was so cute Coyote had to laugh at him. The next day and the next Coyote was busy chopping food for his adopted child. After some days of this he thought, " $\mathrm{My}$, you are a greedygut!" He cut another tree. It lay there. He looked around for Little Beaver but he was gone. Then Coyote was sorry. He went home, lay down and covered himself up with his blanket and cried.

Mother Beaver came in. "Are you asleep?" she inquired. "No." "My child came home because you called him greedy." "I just said that for fun. I like him. He plays around and then I feel happy. Then and then only can I laugh." She said, "All right, if you chop enough for him to eat he will come back to you. I am going to avenge the death of your children." "All right."

The next day Coyote took up his ax again and Little Beaver devoured trees faster than he could cut. For about a month he did this. Finally there were only small branches left. In about two days all these were gone. Little Beaver said, "I am going back to my mother." "All right, go on home."

When he got back he was a man. His mother dressed his hair to show he was grown up. She combed it and braided it, then she folded it up behind, tied it and stuck his arrowpoints in it. Then she split in two the toe next to the small one and advised him, "When you go in to the place where Coyote's children were killed they will give you something hard to eat. You will see the marks of teeth in it. They will be the marks of Coyote's poor children. The one who gives it to you is Grizzly Bear, he killed Coyote's children. Go now."

Little Beaver went into the old man's house and sat down. He gave him the hard food. The toothmarks of Coyote's children were in it and said, xat'at'at'a as he ate it. Nevertheless he was able to eat it all up because he had eaten so many trees. The old Grizzly said, "You are not afraid of us." Then he went out.

Then the false Coyote began to cry, "He's lying down." That was his sign to the Grizzlies. Little Beaver jumped up. He stepped into the fire and caught a hot coal in his cleft toe. He took this so he could melt pitch to fasten his arrowpoints. He ran toward the canyon and over a cliff. Then he sat down to fix his arrows. He took the points out of his hair. He blew the coal, melted the pitch and fastened the points to the 
shaft. Four times he did this and ran back. The false Coyote called to him, "Look out, he'll claw you and bite you. Don't run on top of the hill, run underneath," but Little Beaver went along the top of the hill, shot Grizzly Bear and killed him.

He cut off Grizzly's paws and took them out. Grizzly's relatives began to cry. "Keep quiet," said Coyote, "he'll be back." Little Beaver strung the four paws on a stick, came back and threw them into the fire saying "Take them, you can go defecate on them."1

Then he ran and they chased him. "Oyurayura. . . ." he went fast. They caught up with him. He jumped into the water. They looked in vain for him. He had gone into his hole. He went in, through his tunnel under the river and out the other side into Coyote's house. He said, "I killed the one who murdered your children, get ready to save yourself."

Little Beaver ran out. Coyote took out his powers and consulted them. His first power said, "I will be a bear-trap, get me ready." The second said, 'I will be the bait, I'll be fat for you to put in the trap." The third gave him an arrow. The fourth told him to lie there as if he were dead with his fur full of maggots.

Grizzly's father started after the enemy. He came to Coyote's house saying, "I'm going to kill Coyote." When he got there he said, "I'm going to bite you to death." He saw a trap baited with fat. He saw Coyote lying there swarming with maggots. "I am going to bite you," he threatened. "Go on, bite me!"

The bear tried to bite Coyote but his nose got stuffed with maggots. His teeth were all loose. "I won't bite him now, he's dying already," he said as he went out. On the way out the grease in the trap attracted him. He reached farther and farther in until his head was in the trap, then still farther until he was in up to his waist. The trap fell.

Coyote sang, "Axoiya xoiya xoiya, aunties, our trap caught him." $\mathrm{He}$ jumped up, the maggots were all gone. He was well. His aunties, the mice, ran and picked up rocks to throw at Grizzly. "Don't do that," he begged. Coyote took an arrow from his quiver and stuck it crosswise in Grizzly's throat. His aunties threw the rocks down his throat. He died.

They cut off his head. Coyote took a stick and propped the mouth open with it, then he climbed up and put the head on the house poles. He fixed the trap again and lay down. Grizzly's mother now came and acted just as her husband had, and she was caught in the trap the same way. Coyote set her head on the house poles.

Grizzly's daughter ran out for revenge when she saw the heads of her father and mother. She said, "I am going to get you, Coyote, I will bite you. I am going to eat your flesh and bones. Nothing will be left of you.

${ }^{1}$ Almost certainly a phrase taken from the Whites. 
You are an ugly thing." She came close to him. He ran and she chased him. He looked back and laughed. "You are very young." She said, "I am going to bite you no matter how far you go."

He went over the hill. She followed but he was gone. She saw his tracks, but as she was looking for them she saw a pestle lying there. She thought, "I will take it with me." She put it under her dress. It moved around. She was running aimlessly. She thought, "It must be this pestle that is making me run this way." She threw it away. As she ran on Coyote called to her, "Ha ha ha, your belly is getting big, you are going to have a baby."

Coyote had turned himself into a pestle and had impregnated her. She kept on saying, "I am going to bite you." Coyote kept on taunting her.

That is all. The end of the road.

An analogous myth, in which Coyote's youngest son takes the place of Little Beaver, is to be found in Okanagon mythology:

Grizzly Bear kills Coyote's two older sons; the youngest Coyote shoots Grizzly's daughter; Coyote escapes from Grizzly by a ruse and drowns him (MAFLS 11 :79).

\section{Coyote Devours His Own Children}

Coyote shoots his neighbor, Deer

Coyote pretends to doctor Deer and kills him

Coyote kills Deer's wife and child

Coyote kills his own sons, spares his daughter

Coyote kills goose and eats it all while daughter hungers

Coyote's wife, Mole, saves their daughter

Coyote gets a noise in his head

Coyote and Deer were neighbors. Deer had two children, Coyote had five, four sons and a daughter. Coyote used to go away every morning and come back at night. Deer left at night and returned just before sunrise. Coyote wondered why Deer was always away at night, so one time he followed him. He saw him stop at a little gulch and eat. He saw he was eating dirt. Coyote thought, "I'll kill him." He got his arrow ready, but left it to dry. Then he warned Deer, "Don't travel at night, now that the moon is shining. You might be killed."

Deer did not answer, and he did not heed the warning. Coyote took his arrow and went to Deer's grazing ground. He made a brush house in which he waited for Deer. Deer came and licked the dirt like meat. Coyote shot him in the entrails, whereupon Deer ran home with Coyote after him. Coyote arrived home first and blew ashes over Deer's blanket 
so it would look as if he had been there a long time. Deer ran into his house, blew up the fire and groaned. Then Mole, Coyote's wife, heard it "hi hi hi!" "Someone is suffering," she cried. "Oh, stop prowling around in the night," said Coyote.

She got up and made a fire, then went in to Deer. "Where is it? Let me look at it." "Here it is, the arrow is still sticking in," said Coyote who had followed her. He pretended he was pulling it out but kept pushing it back and forth in the wound. Then he told Mole to make a fire in the sweathouse. She said, "Halalas, what is the matter? It will be too hot." "Don't answer me back, go do as I say."

Mole was obliged to make the fire. Coyote took Deer into the sweathouse. Then as Coyote pulled out the arrow he sucked Deer's fat. "Be careful," said Mole. "You shut up!" ordered Coyote.

Soon Deer died. His wife cried. Coyote told her to be quiet. After a little while he said, "I will fix your hair in widow's style." He took a knife. "Don't cry now. Put your head up."

He lifted up her braids and cut off her head. She died. Then Coyote took a stick and killed one of the Deer Children. The other deer ran off. Coyote butchered the deer and took the meat to his house. He said to Mole, "Get out of my way. You might spoil my hunting luck."

She went out and made her own fire. She cooked and the children all ate but she herself ate nothing. This went on for some days. Then there was nothing but blood left. Coyote said to his eldest son, Raven Head, "Go get some camas. We'll mix it with blood."

There were only two camas in the sack. "It is because Mole ate them all. Your mother is a greedy thing."

Coyote went himself and looked, but the sack was full of dirt and only two camas were there. He was very angry, "Now you are going to die, you Mole."

He hunted a stick and went out to where she had been sitting, but she was not there. She had gone into her hole. He put his hand in but could not reach her. He cooked the blood. Then there was nothing to eat. Coyote said to his youngest son, "Come here." He began to delouse him. He bit him in the back of the neck pretending it was a louse. $\mathrm{He}$ died. Coyote cried, "Hä hä hä, Chief Raven Head died." Then he said to his children, "I guess we'll have to eat him."

So they ate Coyote's own child. He deloused, killed and ate the other three sons in the same way. Only the little daughter was left. Coyote said, "I won't kill you. You are pitiable. Come, I'll carry you. Let's look for mama."

He went along carrying his child. Suddenly he heard a wild goose way up in the air. Coyote looked up. He said, "I told you all I need to do is to look at them and all cultivated people die." 
He went on. The geese came closer. "uxapxapxapapap" they flapped around him. He looked at them. They died. "Ha! Now we'll have plenty to eat, daughter." The geese lay all around. "Oh, that's fine. We'll eat now." He went to get cedar bark to make a bucket. The baby said, "Oh dädä, the gooses gone!" He hushed her up. "They know you have no mother." He was making the bucket of bark when she lisped again,

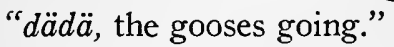

Then Coyote looked up and saw the child had hold of the goose's leg and the goose was flying off. "I won't let go," she cried.

Coyote ran right under the goose and grabbed her. Then he killed the goose. It was the only one left. He made a bucket in which he cooked it. He gave the head to the girl. He ate every bit and even drank the broth. Then he saw the girl crying as she was eating the head. "Give it to me, I'll fix it for you." He took it away from her and ate it all. She kept on crying "Come! Let me carry you. We'll look for mama."

After they had gone a long way they saw a woman who was wearing a red dress ${ }^{1}$ digging camas. He said, "There's your mother," and to the woman, "All our children are dead."

She did not even turn her head. He came closer and repeated, "All your children are dead." Still nearer he repeated it but she kept right on digging. Then suddenly she darted into her hole. Coyote peered in. There he saw all four sons eating. "Why didn't you let me know? All this time I have been mourning my sons. Make the door bigger so we can come in. We are hungry." "Give me the little girl first."

He handed the baby in to Mole. Then the hole became smaller and smaller. When it was just big enough for his eye to peer through he saw his little daughter eating as if she were starved. Coyote called, "I'm hungry too. Give me something to eat."

They kept right on eating and paid no attention to him. Gradually the hole closed. Then said Coyote to himself, "I'll sleep here. I'll put my ear down and I can at least hear them. The noise is as comforting as if I myself were eating."

He fell asleep. Mole, hearing nothing, looked up. She saw his ear was right over the hole. She took her pans (?) and threw them in his car. When he woke up he said to himself, "That's right, I was listening. I'll look in again."

He heard "ola' $u$ ola' $u$ " in his ear. He wondered what it was. He tried to shake it out. It kept on. He said, "Oh, my! I have a nice noise in my

${ }^{1}$ When Mole was home she wore gray but when she went out to dig camas she wore a red dress. "Just as soon as she leaves me she dresses up," complained Coyote whenever he saw her so. 
head. When I get to a celebration I will be called, 'The One with the Noise in His Head." "

That is the end of the road.

A close parallel to the Coeur d'Alene story is found in a myth of the Columbia River tribes. There are but two minor variations: Coyote kills three of his sons, sparing the youngest, who is however dropped to his death by the escaping geese; Coyote's wife finally leads Coyote back to his children, reuniting the family (Idaho Farmer, Sept. 18, 1930).

The killing of a neighbor, relative or intimate friend is a common theme in Coyote and Raven cycles. It occurs in myths of the Wishram, Wasco, Tsimshian and Kathlamet.

Coyote warns the Deer people to look out for a mystery being; each morning Coyote treacherously kills one Deer (Wishram PAES 2:161; Wasco PAES $2: 271)$.

Raven visits his "brother-in-law" Deer; the next day Raven kills and eats Deer and his store of provisions (Raven also kills Deer's wife) (Tsimshian ARBAE $31: 89 ;$ BBAE $27: 63$.

Coyote warns his house-fellow Raccoon of warriors; Coyote shoots, pretends to doctor, kills and eats Raccoon; Coyote is left starving (Kathlamet BBAE $26: 152)$.

In Thompson and Shuswap myth is found the theme of Coyote's attempt to kill birds in flight.

Coyote knocks down geese which respond to his call; the geese revive and carry off Coyote's son; Coyote strikes his son by mistake; the geese escape (Thompson MAM 12:310).

Coyote's son is unable to hold down the four swans which have fallen in response to Coyote's song and dance (Shuswap MAM 4:638).

In a Shuswap myth of a supernatural type the ugly youngest brother succeeds in depriving swans of their power of flight and clubs them after the shamans and Coyote have failed (MAM $4: 703$ ).

\section{Coyote loses his Eyes (Eye Juggling)}

Coyote comes to Pheasants' house

Coyote bakes Pheasants' children

Pheasants kill Coyote and revive children

Coyote revives, but has a broken leg

Coyote eats his own marrow 
Children taunt Coyote; he turns them into crossbills

Coyote juggles with his eyes which are stolen

Coyote steals Catbird's eyes

Coyote threatens a woman in the trail with nettles

The woman becomes Coyote's wife

Coyote and his wife come to a dance

Coyote tries to get fat which turns to rock

Coyote is buried in rocks

Woodpecker pecks rocks from Coyote's eye

Coyote taunts Raven who picks out his eyes

Coyote's wife scatters the remaining rocks

Coyote's wife aims arrow, Coyote shoots a deer; wife pretends he missed

Coyote's wife gives him medicine for eyes

Coyote breaks taboo, eats medicine and becomes blind again

Coyote makes eyes of pitch

Coyote comes to house of old, blind woman whose grandchildren are dancing with his eyes.

Coyote kills old woman; grandchildren carry him to dance; he recovers his eyes

Coyote leaves spittle behind singing while he runs off taunting his hosts

Coyote was going along. He went into a house where there were many children. It was dusty in there. The mouths of the children were dirty. "What are you doing?" "We are baking berries." "Where are they?" "There in that sack." "Go get me a sack. I am going to bake some."

They brought him a sack. He fixed the oven, put berries in, covered them and put fire on top. "Eat so you grow fast," he told the children. $\mathrm{He}$ ate also. "Did you have enough?" "Yes." "Who is your father?" asked Coyote. "He Flaps on the Head." "And your mother?" "She Darts between the Legs." "Bring another sack," ordered Coyote.

He killed the pheasant children and arranged them around the fire. Then he went off. He sang. "They don't make their children mind."

The pheasants were picking berries and heard him singing for about a mile. The man said, "I suppose he has done something to our children. You stay here. I'll go see what is wrong." He flew home and found his children all dead. He went back and told his wife. "It's pitiable about our children." She said, "Let's follow him."

They flew. "Pheasants' children don't mind," sang Coyote as he went along. The Pheasants took a road which ran right along the edge of a cliff. They waited there for Coyote. He came along singing. The man said, "I'll be the first, I'll fly at his face."

${ }^{1}$ In the original there is a play upon words here making the two phrases at once an obscenity and a threat. The threat was that the father would come flying suddenly past Coyote's head and, as he jumped aside, the mother would fly suddenly between his legs. 
When he was right over Coyote he defecated. As Coyote jumped the mother flew between his legs. He was so frightened he fell over the cliff. The pheasants went home. It was awful to see the children. The parents cried. They picked up the remains, washed them and stepped over them. Then they became alive.

As for Coyote he fell from the cliff and died. He got up after a while. $\mathrm{He}$ fell again. He found he had broken his leg. He looked where his leg was broken. He saw marrow on it. He scooped it up on a stick and tasted it. "My! It's good, my marrow."

$\mathrm{He}$ ate it all. He took a piece of willow. He chewed it and stuffed it into the hole in his bone. He ate off the end of the other piece of bone and stuffed chewed willow in that. Then he pressed the two ends together. Some children saw him do this. "Self-Taster is Coyote," they called at him. "You lie, you lie! Come fix it for me! I broke my leg."

Two of the children came. "That's for no good you say that 'Coyote tasted himself.' I am only fixing my leg." He grabbed one of them and twisted his mouth. He did the same to the other and said, "Now let's see if you say, 'Coyote is a Self-Taster!' " But they could now say nothing but, " $t s u, t s u$, $t s u$." They had become crossbills.

Coyote went off. He saw a man throwing up his eyes. He ran and said, "My eyes, come back again!" Then they dropped into his sockets again. Coyote said, "My gr-gr-gr-grandfather knew that trick too. Do you think you are the only one who knows it?"

He took out his eyes and threw them up. "Come drop back, my eyes!" But the man ran and caught them and Coyote had no eyes.

He went on. He heard someone say, "Coyote is going to fall off." Coyote was pretending he could see and would not look at the man. $\mathrm{He}$ thought, "Maybe he sees a deer." He asked, "Is it a deer you see ?" $\mathrm{He}$ made signs, "What? What? Where are you ?" "There, don't you see it!"

Coyote took him by the head, "There it is. Come I'll aim your eye. I'll point right at it."

He took hold of the man's head and aimed it, then pulled out his eyes and put them into his own sockets. He could see again. He threw the man over the cliff. He became Catbird (canyon wren?). He said, "When anyone hears you he will become lonesome."

Coyote looked and saw that if he had taken one more step he would have fallen over the cliff. He had eyes again but they were very small. He went on. He saw a woman sitting in the trail. He said, "Move aside!" She paid no attention. He said, "I told you to move over. Are you dead?" She sat still. He went near to her ear and shouted, but she did not answer. He went still closer and said, "Are you blind?" 
He was thirsty. He went down to the spring. He drank. He found some nettles and pulled some out. He went back and said, "If you don't move I'll touch you with these." He touched her with them. "Don't! I'll move. Only don't touch me with them." He sang, "If you don't move I am going to touch you with nettles." "Stop it! I'll move. I'm going with you." "Why should you want to go with me?" "I'm going with you." "Why didn't you say so long ago?"

They went along together. At night they heard singing. Coyote said, "Let's go see what it is." The woman said, "No, we are going on." "Just for a little while." She said, "No!" and went on.

Coyote went in. The people were dancing. He danced too. He saw hanging bladders full of fat. He said, "I will blow out the light. They used to dance in the dark." He blew it out. He found the tallow and jumped up at it. There were only rocks. He tried another bladder. It made a noise like rocks. "Light the light," he said. When it was light again he saw there were no people. "Where are you?"

Everywhere he moved there were rocks. They came closer and closer together. "Where are you, my partners?" he cried, but no one answered. He cried and cried but finally he could not even move his head for rocks. In the morning he heard animals pecking. "Come over and help me out. Peck me out of here."

Woodpecker pecked around his nose. "You are pitiful," he said. "Peck out my eyes so I can see people." "All right. I will get you out." $\mathrm{He}$ pecked all around Coyote's eye. At night he said, "It is dark now. I will leave you, but I will come back in the morning."

He went home. He tied up his head. "What's the matter?" asked his wife. "I bet you were pecking at that Coyote." "No. I was pecking for something to eat. All day I was busy at it. That is why my head aches."

The next day Woodpecker worked again. About noon he got to Coyote's eye. Then he could see with one eye. "Now you are all right. You can see again. My head aches terribly, so I will leave you."

Coyote could see the sky. Soon he heard "cu cu cu." He saw it was Buzzard flying above him. "My! You are ugly! I shouldn't be looking at you. You are black. Your legs are rough, your eyes are white, your nose is long."

Just as Coyote said, ". . . ugly" Buzzard swooped down and, " $t c$ 'ar $t c$ 'ar," picked out his eye. Coyote set up a howl, "I can't see any more." He took his head in his hands and moved the other eye to the hole. Buzzard picked it out.

Then the woman, who was sitting where Coyote had left her, threw out her belt and caused the rocks to scatter. She led him away. Soon she saw a deer. She said, "There's a deer. I wish there was a man to shoot 
it." Coyote said, "Am I not a man? Fix an arrow for me and aim it. You hold it still and tell me when it is ready. Then I'll shoot."

She did as he directed. He killed the deer. Then he praised himself, "My, I am a pretty good shot! I killed that deer all right."' The woman said, "You shot a tree." "Oh! I was just talking." "Come let's get the arrow." She took it out of the deer and put it away. Then she led him around in a circle all day. Finally Coyote said, "Aren't we near the place where we can go through because I think I know it? It seems as if we were going the wrong way." "We're a long way from there." "I don't know, we've already gone over many hills." Then she told him. "No, we've only gone over one. It was bad to walk over."

Coyote had thought he was going over many logs all the time. The woman was lying to him. He had really shot the deer. They were right near where the deer was lying. "We'll camp here," decided the woman. "Sit down right here. I will make the fire."

She made a big fire. Then she said, "I am going to fix some medicine for your eyes." Coyote sat there patiently. She cut up the deer and broke the bone at the knee. "My! It sounds good. She is breaking the deer's leg." "I just broke a stick." "Oh, I was only talking." She roasted the liver, tci $\cdots$ lasasa. "My! That sounds good!" "The wood is wet, that is the reason it makes that snapping noise." "I was only saying. ..."

She took some fat and tied it up. "It is true you killed a deer." $\mathrm{He}$ said, "I know I did." "I will lead you over to get the medicine. We'll eat when you get back." "Don't you taste any till I come," he begged. "We'll eat together." "Go on, hurry! Take this," she said as she handed him fat tied up in deer intestine. "When the water comes up under your arm throw it in, but don't look back at it. Come without looking back."

Coyote started off. He looked back. He saw the woman cooking. "Don't eat till I come," he called. He had not even gone as far as the shore whent he thought, "I didn't even see what kind of medicine she gave me. I better look at it so if I have sore eyes again I'll know what medicine to use." He saw it was fat. "Why that's not medicine, that's something to eat," he said and bit at it. He swallowed it all and every-

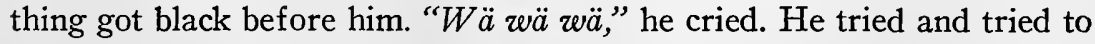
vomit it up, but in vain.

"What's the matter now?" said the woman. "You crazy Coyote. You'll have rust around your eyes. You think I'll lead you around again soon. You can just keep wandering around."

She went off in disgust. Coyote went along crying. He ran into something. He felt around. $\mathrm{He}$ was in the timber; it was a tree. He took some

${ }^{1}$ The woman must have been a Colville because Coyote said "deer" in the Colville language and the man must speak the woman's language (Julia). 
pitch and rubbed it in his eyes. Then he could see a little but everything looked blurry. He got more pitch. Whenever it got warm the pitch melted and he had to keep on making new eyes.

After a time he saw a house where someone was singing. An old woman lived there. She had four grandchildren who were dancing and singing with Coyote's eyes. The old woman herself was singing to accompany her pounding of sunflower seed. Coyote went in and saw she was blind. "Well, you are pounding away," he said cheerfully. She did not answer so he tried again, "You are home today." Again, "Oh, I didn't know." "Don't you know anything?" "No." "Don't you know Coyote took away my eyes?" They are dancing with some eyes and playing with them. "Oh! I didn't know it." "Come in again tonight. I have four granddaughters. " They'll stop playing with the eyes then. Come back and as soon as the sun goes down I will be taken over and I will have my eyes for the night." "All right, I'll go along too."

Then she warned, "Go along now, that is the Chief, Chief Coyote." "Is he a chief ?" The old woman said, "Really you are pitiful. Of course Coyote is a big chief like the deer with antlers." "Well I guess I better go then."

Then Coyote took a stick and killed the old woman. He pulled off her dress and while doing so tore his eye a little. He pressed the tear together and the hair stood out straight. He put her dress on himself. He tied up his eye. He laid the old woman in the corner and covered her. Then he sat down and pounded and sang, "My grandchildren are playing with Coyote's eyes."

The children heard him. They laughed and said, "It is Coyote's voice. What is the matter with our grandmother?" They went in and asked her. "I have been singing all day. That's why I am hoarse." "Why is your eye tied up like that?" "Some of these sunflower seeds flew into it." "Well, go get ready." "I am ready, I'll go get Coyote's eyes," sang the old woman.

They ate what she had pounded. They went to the dance. The oldest one carried the old woman on her back. She started to run. "Oh my chest hurts, go more quietly." "No, we're in a hurry!"

She had not gone far with her load when she put it down and her sister took it up. Every time Coyote asked one of them to slow up she refused at first, but finally consented. So it went on until all the old woman's grandchildren had carried him. When they came in sight of the dancehall the youngest put him down and the people helped him in. He said, "Where are Coyote's eyes?"

1 The granddaughters were birds: Nighthawk, Waterbird, $x w i ' u x w i n$, and Killdeer. 
They set the pot of water containing them near him. He felt around in it. "Here are my eyes lying in the water. Oh thank you! At last I have my eyes back. Let's dance now." Coyote took up the eyes and the people began to dance. He sang, "Put out the light. Long ago they used to dance in the dark."

The light was put out. He tore off the dress and threw it down. Then he spat on the floor and ran out. The spittle kept on singing but it got weaker and weaker. "Let's have light, the old woman is dying." They got a light. There was no old woman. They found it was the spittle singing. The eyes were gone from the pot. Then they said, "It must have been Coyote himself."

Outside they heard him laugh. They knew him only too well. "The Chief has taken his eyes from us," they said. Coyote ran off, they chased him.

The end of the road.

Each of the four main episodes of the Coeur d'Alene myth-Coyote's experience with the Pheasants, Eye-Juggling, the deception of the blind hunter and Coyote's recovery of his eyes-occurs frequently in the myths of other tribes, but a combination of all four, such as is found in the case of the Coeur d'Alene, does not appear. Three of the episodes however are combined in an analogous Shuswap myth:

Coyote comes to Foolhen's home; he gums the eyes of wood partridge, prairie hen and partridge, Foolhen's children; the mother and children frighten Coyote off the cliff. Coyote plays catch with his eyes; Daw steals then; Coyote makes eyes of rosehips. Coyote comes to the house of a woman whose four daughters are dancing with his eyes; Coyote snatches his eyes and runs off taunting them (IS 7).

Detailed accounts of Coyote's loss of his eyes which correlate with the Coeur d'Alene Eye-Juggling and Eye-Recovery episodes are found in the mythology of the Sahaptin, Nez Percé, Kutenai, Thompson and Coast Salish:

Coyote imitates Wildcat juggling with his eyes; Wildcat steals Coyote's eyes; with the aid of Elbow Boy Coyote steals a man's eyes; the man becomes Catbird. Coyote comes to an old woman who tells him the people are dancing with his eyes; Coyote kills her, her daughters carry him to the dance, he regains his eyes and flees (Fox overtakes Coyote; Coyote sends Fox back) (Sahaptin MAFLS 11:155, Nez Percé JAFL 21:19).

Snipe juggles with his eyes; Coyote steals Snipe's eyes; Snipe takes Coyote's eyes; Coyote makes eyes of gum, of foam, and of huckleberries; he steals some children's eyes. Coyote kills an old woman, her two granddaughters carry him 
to the dance, he recovers his eyes and escapes, taunting the people (Kutenai BBAE $59: 183)$.

Deer people imprison Coyote in a house of ice; Coyote licks a hole through and passes out his body parts; Raven (Crow) steals his eyes; girls taunt blind Coyote; he takes the eyes of one, Catbird; the people put red bearberries in her sockets. Coyote kills a half-blind woman, girls carry him to a dance, he regains his eyes and runs off (Thompson MAM 12:308).

Among the Coast Salish tribes variants of the myth in different settings have been recorded and grouped together. In an Upper Chehalis version, following the general pattern for that group, and in the Wynoochee and Satsop versions Woodpecker pecks Xwan out of the stump in which he is imprisoned and takes away his eyes and anus; Xwan uses wildrose centers (berries) for eyes; he tricks Snail woman into trading him her eyes. Xwan comes to the people who are playing with his eyes, retrieves his property and runs away. In the Cowlitz myth, Xwa'ni, imprisoned in a stump, eats up all his flesh, including his eyes; when released and revived by the Woodpeckers, he uses dogwood blossoms for eyes; he tricks Waterbird into exchanging eyes with him; he juggles his eyes; Raven steals one. Xwa'ni kills an old woman, her granddaughters carry him to the games, he recovers his eye and runs away (MAFLS $27: 384$ ).

Three less elaborate accounts of Coyote's eye-juggling experience are related in a Thompson, a Nez Percé and a Shuswap myth.

Coyote imitates Blue Grouse juggling with his eyes; Raven steals Coyote's eyes; Coyote uses bearberries for eyes; a boy taunts Coyote, Coyote takes the boy's eyes, gives him his bearberries as substitutes and transforms him into a bird. [In an appended fragment it is related that Coyote assumed the appearance of an old woman and was carried to a gathering by four girls, whom he impregnated. (The recorder was unable to find anyone who knew the remaining details which, it was claimed, dealt with Coyote's recovery of his eyes.)] (Thompson MAM 12:212.)

Coyote imitates a man juggling with his eyes; the man causes Coyote's eyes to be lost; Curlew taunts Coyote ; Coyote takes Curlew's eyes and gives him serviceberries as substitutes ( $\mathrm{Nez}$ Percé CUCA $25: 68$ ).

Coyote imitates Holxoli'p juggling with his eyes; Raven steals Coyote's eyes; Coyote uses two roseberries for eyes (Shuswap MAM 4:632).

The assumption of a disguise to recover lost property is a stylistic device of widespread distribution.

In one of numerous typical examples, a Haida myth, Raven pulls off an old man's skin and gets into it; in this disguise he gains entry to the house where the stolen arm of the chief's son is kept; he recovers it and flies away as Raven (BBAE $29: 136$ ). 
The Coeur d'Alene account of Coyote's experience with the pheasants finds analogies in myths of other tribes not linked up with the eye-loss: Sanpoil, Pend d'Oreille, Okanagon and Shuswap.

Twelve Willow Grouse children tell Coyote their parents are out gathering berries; Coyote assumes the children are calling him names, puts pitch in their eyes and blinds them; the Willow Grouse parents hide and frighten Coyote off the edge of a cliff; Coyote falls into the water below in the form of a basket ${ }^{1}$ (Sanpoil MAFLS $11: 101)$.

Coyote gambles with Chickadee and wins everything; Coyote bakes Prairie Chicken's children; Chickadee revives the children; the Prairie Chicken parents frighten Coyote off a cliff; Chickadee recovers his clothes and bow and arrows (and shoots an arrow chain) (Sanpoil JAFL 46:157).

Similar to the above is the Pend d'Oreille myth which is also found in a like form among the Okanagon: Coyote cooks ten Willow Grouse children; the Grouse parents, Flying Past Head and Flying Past Between the Legs, frighten Coyote off a cliff; as Coyote falls, the Grouse snatch back Wren's losses to Coyote at gambling; Wren revives the Grouse children; Fox revives Coyote (Wren shoots an arrow chain) ${ }^{2}$ (MAFLS $11: 114$ ).

Coyote puts gum in the Grouse children's eyes; the four Grouse mothers clean their children's eyes and startle Coyote into falling off the precipice; Coyote falls into the river and is doctored by his wife; he floats downstream (Shuswap MAM $4: 628,740)$.

There is also the analogous sequel to the Kutenai myth in which Coyote gives Locust a ride: Coyote and Locust meet a Grizzly Bear; Coyote sets Locust down at the edge of a cliff; Locust scares Grizzly into falling off the cliff; Grizzly dies. To the above myth is appended the footnote: "The idea of a person being frightened by the sudden flying up of birds or by a sudden movement, and caused to fall down over a cliff, is rather widely spread" (BBAE $59: 2,293$, n. 2).

Further references in addition to those already considered include the Ojibwa (PAES 7, pt. $1: 187,415$; pt. $2: 41$ ) ; the Lillooet (JAFL 25: $305)$; the Assiniboin (APAM 4:110); and the Pawnee (CI 59:459).

In the Ojibwa versions Nanabushu eases himself upon young birds (twelve ruffed grouse) who call themselves Winged Startlers (Little Frightener); their mother, Ruffed Grouse, washes them and scares Nanabushu into falling into the water; he swims away, admitting the birds' identity.

In the Lillooet fragment Coyote puts gum in the eyes of the Grouse children, which their mother cleans out again.

${ }^{1}$ The action continues into the story of the Salmon Release (see tale 8).

${ }^{2}$ None of my informants knew the Arrow Chain tale (G.A.R.). 
The Coeur d'Alene episode of blind coyote shooting the arrow which the woman aims for him appears frequently in other myth bodies, often elaborated to the proportions of a myth complete in itself, never as in the Coeur d'Alene combination. In each of the versions the blind hunter eventually regains his sight with the assistance of Loon's supernatural power and the woman who deceived him is deserted or killed: Chilcotin (MAM 4:35); Tsimshain (ARBAE $31: 246$ ) ; Haida (MAM 8:212, 263; MAM 14:354); Southern Puget Sound (UWPA 3:139); Kwakiutl (CUCA 2:448); Rivers Inlet (IS 229); Tlingit (BBAE 39: 104); and Smith Sound Eskimo (JAFL 12:169; ARBAE 31 :952).

Thompson and Shuswap examples of Woodpeckers' assistance to those entrapped in rocks reveal one further point of departure for a comparison with a Coeur d'Alene element.

Coyote gets caught in a cave; four Woodpeckers succeed in splitting the rock; Coyote is released (Thompson MAFLS $11: 9$ ).

Bluejay after killing a monster is trapped inside a cliff; the Woodpeckers peck him out (Shuswap MAM 4:662).

\section{Coyote Hunts with Crane and Releases Salmon}

Chief sends his two daughters to Crane as wives

The girls eat camas off door; they are fed with meat

Crane accompanies girls on visit to their father

Crane carries much food in little

Coyote taunts Crane about his loud voice

Crane conducts hunt

Coyote imitates Crane unsuccessfully, kicking dead tree to start fire

Coyote disobeys Crane's orders: Crane calls deer; Coyote does not have arrows ready and shoots only two fawns

Coyote imitates Crane unsuccessfully, carrying deer on each side of belt.

Coyote goes down river

Salmon dammed up by four man-eating sisters

Coyote's powers become digger, armor, baby and log

Sisters adopt weird foundling

Foundling breaks salmon dam, releasing salmon, escapes as Coyote

Four Wolves and Fox steal Coyote's salmon

Coyote steals wolves' eggs, leaves excrement in their place

Coyote distributes salmon, leaving none where he is refused wife

Coyote becomes rock

There was a village. Far from the village Crane lived with his grandmother. Crane was a good hunter and always brought back many deer. One day the chief said to his daughters, "Go to Crane's house. Maybe he'll share venison with you. Then we'll have a bite of meat to eat." 
The girls went to Crane's house. As they came in sight they heard his noise, qwar qwar. When they came up to the door they saw it was dotted with cooked camas. They picked it off and ate it. As they did so Crane said, "Leave grandmother's things alone. That is the old woman's door curtain. Grandmother will look for something for you to eat." Pieces of camas were fastened to the door curtain but each girl thought, "I am so hungry for meat. I hope they will give us something besides those pieces of camas that are left over." Crane said, "That is not really camas. Come in and let grandmother cook for you."

They went in and sat diagonally opposite the grandmother. At the other end of the fire on their side was a pile of rocks. Crane sat there. Then he said to his grandmother, "Hurry cook for them so they can eat."

His grandmother cooked meat. After it had boiled she dished it up and placed it before the girls. Then she took a piece of fat and cut it in half, then in quarters. She put two quarters in each dish for them. The eldest whispered to her sister, "Don't eat it! The meat is greasy. Keep is so we can grease our hands."

Crane said, "Go ahead! You can eat it all. There will be plenty to grease your hands." So they ate it all.

Mornings Crane would go out to get deer. He would get two each time. He hung one on each side of his belt. About two days later he would go again and do the same thing. He never took more than two but there was always plenty of meat of all kinds hanging in the house, fresh, smoked and dried. One morning he said to his grandmother, "Get food ready and do not grudge it. Today they are going back to their parents. She made huge bundles of meat and set them outside the door.

When the older girl came out she thought, "That certainly is plenty of meat. But how can we carry it all?" Just then Crane said, "I'll go with you. I'll just put it in my belt." The grandmother said, "It's all ready." Each of the girls had a baby. Crane said, "You just carry the babies and I'll carry the rest." When they were finally ready the bundle was very tiny and Crane stuck it in his belt. The oldest girl was Little Squirrel, ${ }^{1}$ the younger was Chipmunk.

As they came over the hill Coyote spied them and shouted, "There he comes, the one with the raucous voice. I don't suppose he has brought anything for us, his in-laws." When they came up to the door of the house of his wives' father Crane threw the bundle down and went in. The two sisters who had been away so long were glad to see their mother and she was glad to see her grandchildren and took both babies in her

${ }^{1}$ A squirrel a little larger than a chipmunk with spots on its face. 
arms. They were all very happy. Then the elder said to her mother, "Go get the bundle. Now you will eat well."

The mother went out. The girl said, "Take half for yourself and half for the rest of the tribe." The mother was just about to untie it, but her daughter stopped her, "Don't untie it. Get a big mat first." She got a small mat. "That won't do, you must get a real big one." As she untied it it spread and became a huge pile. She put half away for herself and half she tied in a number of bundles for her tribesmen. Meanwhile Coyote was eaves-dropping.

The girl said to her mother, "Go call the people of the tribe. They are hungry." Coyote shouted in, "Shall I call them all, even the children?" He shouted, "Come! You are all invited to the chief's house." He had no more than got the last word out than he ran into the house. The people all came. Some even sat outside. The hosts set the food before them. Coyote ate until he was full. Then he pushed the meat to his children and they ate all they could. Still there was much left.

Coyote said, "Shall we not take the leftovers along?" "Yes," the hosts answered. Whenever Crane went out of the house he made his noise, kwar kwar. Coyote complained, "My, you talk loud!"

One day Crane said, "Get ready! We'll go get fresh meat." "Is anybody deaf that you have to holler so?" said Coyote. They prepared for a hunt. They got their moccasins ready.

Crane said, "Bring me some skins to smoke." They slept. Early in the morning they got up. "Hurry and eat," ordered Crane. The cooks hurried. Crane asked, "Are you finished eating?" "Yes, we are finished." "Go outside." All the people gathered outside.

"Are you all here?" asked Crane. "Yes," they answered. They had not gone far when Crane said, "Let us stop here and make a fire to warm our hands." Coyote asked, "What are you going to shoot that is as tame as all that?" They went on. They came to a dead tree. Crane kicked it. It crackled as it began to burn.

Coyote said, "Oh you know that trick too. My father's father's father used to do that." Coyote went to another tree and kicked it, but it did not burn. The impact made him fall over backward. "Oh! That one must be wet," he said, as he looked for another. He kicked that and fell over again. He tried a third time and failed, then Crane said, "You burnt-eye of a Coyote, come warm your hands and stop that foolishness." Then he said to the people, "Go on now, I guess your hands are warm. Drive the deer toward me."

The people scattered to their positions and Crane busied himself preparing sticks with pieces of scorched skin. ${ }^{1}$ The people drove the deer

${ }^{1}$ This has reference to the method of hunting described by Teit, ARBAE $45: 99$; cp. also tale 40 of this work. 
up. As they came near Crane directed the men not to kill more than two each. "All right now! Get your arrows ready to shoot!" he said.

Coyote did not get ready. His arrow was tied up. "What are you going to shoot? I'm not going to get out an arrow when I don't see anything to shoot." "Ready now!" said Crane.

Then " $h i \cdots h i \cdot \ldots$ " he called, and immediately the deer ran up. No one shot more than two. Coyote was leaning against a tree when he heard a noise on the snow. He saw it was a deer. He reached for his quiver but he could not untie it. So he tore the quiver trying to get out the arrows. He aimed at the biggest deer and shot it. He shot another and there were no more.

Then said Coyote, "It's not because I listen to you but because there are no more." Then he tracked the deer he had shot. He went only a little way and there lay a very small fawn. He went farther and there lay another, smaller than the first. The people came and looked. "That's not my game," said Coyote, justifying himself. "I chose two big ones." "We'll go along and look for your game." They came up to it. "It's your arrow," they told him. "Someone must have substituted his deer for mine," insisted Coyote. Then at last he kept quiet.

"Drag your deer to one place and pile it up," said Crane. Then he checked up, asking, "Did each of you get two? How about Coyote?" "Only two fawns he got." "Well, skin them now and go on."

Crane hung one of his deer on each side of his belt. Coyote saw him, "So you know that too. My father's father's father used to do that." $\mathrm{He}$ tried the same stunt but, as he went along his game dragged on the ground even though he had only very small fawns. His belt was really Mole's carrying strap. "My! It might break!" He tied it up more firmly and fastened his deer again, but it did break. Crane said, "Burnt-eye, you better take it right home to your children." Coyote used all his strength. He became thirsty. He came to some water and drank. He was burning hot. He thought, "I'll take a swim."

$\mathrm{He}$ undressed and swam. As he was swimming he saw a riffle. $\mathrm{He}$ thought, "I'll go over the falls." He let himself float over. "My! it's nice! I wish there was a larger falls like it."

He saw a large falls. He floated over it and came to where a wide pool spread into a river. ${ }^{1} \mathrm{He}$ followed the river and saw some people.

"We cannot eat salmon anymore because the dam was closed up," he heard them saying. "Why was it dammed up? Anyway why don't you go and break it up?" "No, the people are man-eaters." "What kind of maneaters?" "Four little girls."

1 "It must have been the Snake or the Columbia," interpolated the interpreter. 
Coyote laughed, "How could little girls be man-eaters! I'll go break it up." "No you will be killed." "Who is afraid of four little girls? I'll go and break up the dam. What are their names?" "Snipe, Waterbird," xwr' $x$ xw' $u$ and Killdeer. "I'll hurry on."

He went. He came near the house of the man-eaters which was the cliff over which the water falls. This cliff made the dam and stopped the salmon. Coyote consulted his powers. They said to him, "My! you give us chills, relative." "Hurry, tell me what to do. The people are starving for salmon." The first said, "I will be a thing for you to dig with." The second said, "I'll be your armor, a hard thing to protect your hands and the back of your head." Said the third, "I'll be you in the form of a baby," and the fourth, "I'll be a log." "All right!" Then they continued, "I will be a baby in a box on the log."

Coyote rolled it and it floated on the water, a baby in a box on a log. As the man-eaters were sitting in their house they heard the cry of a small baby, "wr wra." They thought it sounded like a person. They looked toward the water and saw the log with the box on it. They said, "Surely some people must have tipped over. Doubtless the parents were drowned and only the child is left." "Let's go get it. The one who gets there first can have the child."

They jumped into the water and swam toward the log. They caught hold of it and pushed it ashore. The baby was crying. One of them put her finger in its mouth and it sucked in the whole finger. She jerked it out. Then one made a kind of mush of salmon and the baby stopped crying at once. He was satisfied and he went to sleep. He woke up and cried and nothing but the salmon would satisfy him. "utum tum tum" was the noise he made. He grew very fast. He was learning to crawl.

Whenever the girls went to dig Nez Percé camas roots they took the baby with them. They made a little shade for him and fed him salmon. Soon he was able to eat by himself. They dug and dug. Then he said to Waterbird, "I'm thirsty $\ddot{a}$ wä wä !" "I'm busy now, go get a drink by yourself." He crawled off as a baby but, as soon as he got out of sight, he became Coyote and ran to the dam. He dug at it for a short time, then ran back. When he came within sight again he crept.

One of the girls said to the other, "Go look after the baby. He might fall into the water." One went and saw him creeping back. She picked him up. He was crying. She quieted him with some salmon gruel. About an hour later he wanted a drink again, "You know how to get it, go on !"

\footnotetext{
${ }^{1}$ A small waterbird, about the size of a sparrow, gray. Cp. tale 26 in which Waterbird is an insignificant boy. Perhaps this was after he had been overcome.

${ }^{2}$ Coyote to address his powers uses a special reciprocal term of relationship which is never used elsewhere.
} 
This time Coyote dug a larger hole in the dam. They kept doing this for many days. One day Coyote put on his armor and took his digging stick. He stayed so long one of the girls said, "Maybe he fell in." One of them went to look and saw a Coyote. "My! There's a coyote!" she called. They all ran with their digging sticks. They came up and clubbed Coyote over the head and all over his body but his armor protected him. As they beat him the dam broke. "Come! salmon come!" he sang. The salmon were released and went one after another upstream. The maneating girls wept bitterly as they saw it.

As Coyote went along the stream he became hungry. He said to the salmon, "Come, come up on dry land." He cut a stick for a club and stunned a salmon. He made a fire and roasted it on a spit. He thought, "I'll take a nap while it is cooking. Then just when I wake up it will be nicely done." He went to sleep. The wolves saw the fire, the salmon roasting on the spit and Coyote sleeping near. "Let's go take what he is cooking," they said.

There were four Wolves and a Fox. They took the salmon off the stick, took a little of the grease and rubbed it around his mouth and over his hands. They took the burned stick and burned him around the nose and eyes. ${ }^{1}$ They went to a little hill and sat down where they could keep their eye on Coyote. They ate all the salmon. Coyote woke up, "That's right! I remember I was going to eat my salmon." He stretched, got up and looked. There was nothing there. He thought, "Could it be that I have already eaten it? No, I know I didn't eat before I slept, but it looks as if I did eat, only I don't feel full."

" $u \cdots u \cdots$, ," he heard. He looked up and saw the Wolves grinning at him from the little hill. "They are the ones who stole it," he said, then called, "You are going to get it!"

They ran and Coyote ran after them, but he soon tired of the chase and decided to turn back to where he had caught his salmon. He was thirsty. As he bent down to drink he saw something sticking out of the water. He went farther but there was always something frightful looking at him. "My! I can't get a drink, I'll consult my powers." He consulted them, "Hurry up, I am thirsty. You give a person the chills, my relatives. I want to drink, go and get that fierce thing out of the water."

"That's only your own face you are seeing. The wolves made you look fierce. They burned your ears and face. Go drink! Look at your face. After you drink follow the wolves and your friend, Fox, over that way. They have gone to a lake where they are swimming for eggs. When they come out they'll roast the eggs. They'll sleep while the eggs are baking.

${ }^{1}$ That is why he is called Burnt Eyes. 
You go and take them out of the fire, but leave five (imitations), one here and one there. Go over and steal the eggs. At each place defecate and leave excrement to bake. Then go up on a little hill and sit where you can watch the others. You will see them wake up. They will say, 'They must be done by this time."'

Coyote looked at them. He saw the Wolves and Fox standing in the water. They came out of the water and fixed the eggs to bake. "Let's sleep while we wait for them. Just when they are cooked we'll wake up." They slept. Coyote broke the five eggs one by one. At each place he defecated. He took an egg and rubbed it all over Fox's face, hands and body. Then he went up to the knoll and ate the rest of the eggs. Meanwhile he watched the others. After a while he saw one go over to where the eggs were baking. He saw him break one open.

"Wake up, we can eat now. Our cooking is done," he said to the others. They took them out and found nothing but excrement. Coyote said, "What's the matter? Why don't you cover over your dung?" The wolves said, "It's that Coyote that did this to us!"

They ran after Coyote. Because Fox ran fast he caught up with Coyote. Coyote looked around at his friend, "Why did you do that? The eggs were for you to eat. Instead you got them smeared all over yourself."

"Why do you bake your own dung as if it was food?" taunted Coyote. "Why do you turn against me like this. I used to be your friend." "Oh! I was just going along with those Wolf fellows." They went on awhile, then Fox left Coyote.

Coyote went to where the salmon were. He took one to a river in the Nez Percé country and dropped in half of it. He went on to the Colville Reservation near Colville and dropped a portion of salmon. Then he came to Spokan Falls. There he laid down a salmon and said, "I'm a Coeur d'Alene. I'd like to have a wife." He was refused. He went to the Coeur d'Alene living on Lake Coeur d'Alene and asked for a wife. He arranged some sticks ${ }^{1}$ in the water, set up some poles and made a dam. He crossed to the opposite shore and fixed a rock in the water. There he hid his salmon.

He went up to a man and asked him for his daughter. "Give me your daughter for my wife," he asked. But no! Again he was refused. Then he went to St. Joe and Liberty Lake. He shouted to the salmon, "Don't come into this river. There are masmas roots ${ }^{1}$ in it."

Then he went toward the Nez Percé country and shouted, "Don't go

1 The rocks may be seen now looking like the sticks Coyote used.

${ }^{2}$ Masmas roots smell very strong, something like cabbage boiling. 
into the river where the Coeur d'Alene live in this direction. Swim that way."

Then he asked for a Nez Percé woman and got her. There was a nice smooth rock there which was very large. Just as he was standing there the refined people heard a sound of transformation. Coyote had become a rock.

The end of the trail.

The story of the salmon release has a wide distribution, but not in combination with a narrative of a hunt with Crane as in the Coeur d'Alene version. The Crane story was not told by other tribes, even as an independent myth, although the element, "Much in Little" which it contains is used frequently in diverse settings.

In a Kutenai myth Coyote places himself at the head of a line of hunters though he has not as yet obtained any game; he puts flicker feathers in his moccasin so that when he runs fire breaks out; the fire surrounds the door and he kills them; his powers instruct him to blow on his game to make it small, so that he will be able to carry it in his belt as the hunters do (BBAE 59:135; VBGA 23:170).

In a myth of the Bella Coola a boy receives a belt on each side of which he can hang one mountain goat and thus carry his kill home with ease despite its size (MAM 2:59).

Further examples of persons with special powers reducing the size of large loads (of food, utensils, clothes, wood, etc.) so that they may be carried with ease, in gloves, mittens, boxes or baskets, and the expansion of the articles to huge proportions when deposited at home, occur among the Bella Coola (Is 250; MAM 2:90, 105) ; Chilcotin (MAM $2: 27,34,39$ ) ; Shuswap (MAM $4: 689,712,748$ ) ; Haida (MAM 8:202, 265) ; Kwakiutl (CUCA 2:283) ; Thompson (MAFLS $11: 16,29,37$, 44, 54) ; Tlingit (BBAE 39:223, 286); Tsimshian (PAES 3:95; ARBAE $31: 210$ ) ; and Southern Puget Sound (UWPA $3: 85$ ).

The diminution of deer or elk meat specifically, to expedite the task of packing it (most frequently inside mittens or gloves) is treated in myths of the Thompson (MAFLS 6:25,41; MAM 12:205, 263, 268, 375); Kutenai (VBGA 23:163; BBAE 59:287); Wasco (PAES $2: 289$ ) ; Southern Puget Sound (UWPA $3: 93,94,117$ ) ; and Shuswap (MAM $4: 690,691$ ).

Although the Salmon Release in its many phases was not found preceded by a Coyote-Crane myth, it frequently followed some other myth common to the Coeur d'Alene Coyote cycle in other forms.

Among the Thompson, Columbia River, Cowlitz, Southern Puget Sound, Wasco and Nez Percé tribes the Salmon Release follows the Theft of Coyote's Daughter-in-law. 
Coyote, floating downstream as a result of his son's revenge, is taken in in the form of a plank by two women and used as a dish; the dish eats their fish, is thrown into the fire and rescued in the form of a baby. Reared by the women, the child ultimately releases the salmon they have dammed up, as well as smoke, wasps, salmon-flies and beetles; Coyote introduces the fish into all the rivers, but sends none up the Similkameen where the girls refuse his present; at Ntaxase'p the youngest girl accepts it and becomes sick; he cures her; in Okanagon country he is given Wolverene's daughter for a wife; his own daughter is transformed into a rock in the Columbia River (he introduces the fish up the Columbia and Spokane Rivers, but not as far as the Spokane's source, for there he is refused a wife; he is given a wife at Kettle Falls and settles there) (Thompson MAFLS 6:27; MAM $12: 205,297$; Columbia River Idaho Farmer Aug. 7, 1930).

In another Thompson variant Coyote's floating down the river into a salmon trap, and his ultimate adoption as the slave boy of the owners result in his release of the fog and wasps which they were preserving in two baskets. With this the myth ends abruptly (IS 18).

In the form of a wooden spoon, a dish, a horn spoon, and a cooking vessel, Coyote, floating downstream, is taken in by women but each time is thrown away; five girls (Sandpiper Sisters) take him in in his disguise as a baby; one of the digging-sticks breaks, indicating trouble; Coyote breaks the girls' salmon dam and releases the fish; he sends them down the Columbia River; only the small fish are left to go up the Cowlitz; the girls turn into white birds; Coyote's excrement sisters instruct him how to call salmon ashore; as Coyote sleeps five boys (Wolf Brothers) steal the salmon and grease his hands and mouth; Coyote steals the boys' pheasant eggs and paints their lips; he gets two girls; they run away from him (he transforms himself into a stone beside a waterfall) (Cowlitz MAFLS $27: 245$; Southern Puget Sound UWPA $3: 148$ ).

Coyote, drifting down to the ocean, is taken in by two women in the form of a child in a cradle, and releases their dammed up fish; the fish crowd up the Columbia River; Coyote transforms the women into birds (Wasco PAES 2:266).

Coyote floats downstream in the guise of a baby and is taken in by five Swallow girls despite his recognition by the youngest; he breaks down the sisters' fish-trap and escapes, shouting back names for his children by each of the four elder sisters (Nez Percé CUCA $25: 380$ ).

Finally, one may include in this group a second fragmentary $\mathrm{Nez}$ Percé version, which has in place of the long Coyote-Coyote's Son introduction a brief account of an attempt of Coyote's Son to play a trick on his father by giving him a rope of gut with which to carry venison. Coyote's rope breaks five times; Coyote swims down the river and is taken in by five girls in the form of a baby; he breaks their dam and releases the salmon; he introduces the fish up the river (JAFL $21: 18$ ).

In Shuswap and Sanpoil myth the salmon release follows the episode of the Grouse frightening Coyote off the cliff :

Coyote, having drifted into a weir, is taken in by the girl owners for a dish; the dish eats their food, is thrown into the fire and rescued in the form of a baby; 
Coyote is raised by the women, impregnates them and releases the fish; he conducts the fish up the Fraser and Thompson rivers (Shuswap MAM 4:629).

In the Sanpoil myth the boy (Coyote), rescued from the fire, breaks the dam after a month's time and turns the girl owners into Watersnipes and Killdeer; conducting the fish up the rivers, Coyote calls salmon to shore to feed the people whom he passes; wherever girls refuse him for a husband he makes falls to prevent the salmon from ascending (MAFLS 11:101).

The Kutenai combine the Salmon Release with Coyote's attempt to call game:

After the animals have taken revenge upon Coyote because of his overdone imitation of Panther's calling of the game, Coyote drifts down the river as a plank; used by women as a dish, they discard it for consuming all their food; as a baby Coyote is raised by Nighthawk and Snipe; he impregnates them and releases their salmon; rebuffed at Wolverene town, he takes the salmon on to Sparrow's town where he is given a wife (BBAE $59: 173$; cp. tale 17 this work).

The Salmon Release myth is as commonly found as an independent unit as it is in combination with other episodes. In the case of the Sahaptin, the Thompson and the Wishram Coyote starts out with the definite rôle of a transformer. In each case he decides to look into the hoarding of the salmon by various women; has himself adopted as a baby; breaks the barrier and releases the fish according to the general outline of foregoing versions.

In the Sahaptin myth, after Ccyote has freed all the people held captive as fish, he calls for the salmon (in accordance with the advice of his dung boys) belonging to Beaver and cooks it, but some people (Wolves) steal it while he sleeps; Coyote steals the people's eggs and paints them with the yolks; overtaken by Fox, he strikes him on the chest leaving permanent marks (MAFLS $11: 139,140,142$ ).

In the Thompson account Coyote not only releases salmon, but also opens up boxes, containing smoke, wasps, salmon-flies, and beetles at the mouths of both the Fraser and Columbia rivers; he conducts the salmon up all the larger streams of the interior breaking down all barriers; he transforms his daughter into stone (MAM 12:301).

In the Wishram version Coyote takes similar action against the two women who had preserved the fish in a pond and enables the fish to escape into the Great River for the coming people; the women he transforms into swallows (PAES 2:3).

In versions of the Okanagon Coyote floats down the river into the two wet wet sisters' weir (as he is engaged in introducing fish into the various rivers); he is taken in as a baby, breaks the weir and escapes, transforming the sisters into sandpipers; he catches a salmon on his fourth attempt and eats his fill; at those places at which his suit is rejected by the girls he leaves no fish; where the old 
people are kind to him however he leaves some salmon; he transforms his daughter into a stone; given two wives by the Wolverene people at Colville, he provides them with much fish (MAFLS $11: 67,70$ ).

In a Sanpoil version Coyote floats up to the Dove sisters as a wooden platter; thrown away for eating their food, he returns as a baby, breaks their fish-trap and releases the fish; Fox steals Coyote's salmon while he sleeps and greases Coyote's hands and mouth; Coyote steals the eggs of Fox and two birds whom he smears with egg yolk; Coyote tears out dams wherever he is refused a wife, marries Gopher at Kettle Falls; his faeces disguise him as a Kutenai so that he can marry his daughter; Prairie Chickens broadcast Coyote's incest; Coyote's daughter jumps in the river (JAFL 46:173).

In a Haida myth Raven changes into a baby and steals salmon from women who are drying fish. He also steals from a man who catches salmon by surrounding himself with a stone wall and calling the fish to jump at him. In neither incident is there a Salmon Release motive; the myth is concerned with a trickster, rather than a transformer (MAM $8: 212$ ).

Scattered incidents in Coyote's role as distributor of the fish (acknowledged as one of his definite assignments, MAFLS 11:3; MAM 4:637) are found as such in various myth bodies.

In Sanpoil stories Coyote regulates the distribution of the fish according to whether the people are willing to give him a wife or not. $\mathrm{He}$ supplies the tribe of an old man and woman who give him their daughter with much salmon and teaches them how to prepare the fish (JAFL 46:169). He destroys the falls at places where people refuse him their daughters and conducts the salmon further up the river (JAFL 46:172). When his request for a girl's hand by proxy is refused by her parents, he changes the course of the river and leaves the people only sage brush roots, turning the salmon into rocks (JAFL 46:176).

In Shuswap mythology Coyote places a dam across the Upper Chilcotin River to prevent the salmon from ascending, thereby retaining them for the Shuswap. The reason for the restriction in this case is uncertain; some say Coyote acted thus because the Chilcotin were a bad people (MAM 4:642).

Coyote's role as distributor of the salmon is usurped by Ho'tsani in an Upper Chehalis myth. Cloud takes Ho'tsani down to West Wind, where Ho'tsani lives with two women; he discovers a pool of water in their house and sends the spring salmon in it to all the different rivers; he almost forgets the Chehalis River; consequently there are few salmon there (MAFLS 27:137).

The theft of a person's food while it cooks is a theme of wide distribution in the form of a complete myth or a subordinate incident. The numerous versions fit with minor variations into the Coeur d'Alene out- 
line of the episode: food is left to cook while the owner sleeps; the thief tampers with the sleeper to make him believe he ate the food himself ; the owner retaliates and attempts revenge against the thief, with a greater or less degree of success. The story is told in manifold settings and with a wide variety of distinctive details among the Kutenai (BBAE 59:165, 299; VBGA $23: 169$ )-Coyote vs. Lynx; Nez Percé (JAFL $21: 18$ ) - Coyote vs. the animals; Thompson (MAFLS 6:71, 11:7, 8; MAM 12:342)-Coyote vs. Fox; (MAM 12:310) Coyote vs. women; (MAFLS 11:6) Coyote and Fox vs. women; Shuswap (MAM 4:683, 753)-Coyote vs. people; (MAM 4:633)-Coyote vs. Fox; Kwakiutl (CUCA 2:141)-Mink vs. children; Tlingit (BBAE 39:14)-people vs. Raven; Haida (BBAE 29:113) -Raven vs. Crow; Comox (IS 74)Ka'iq vs. Wolves; Upper Chehalis (MAFLS 27:150)—Xwane vs. Wolf; Southern Puget Sound (UWPA 3:76)-Wildcat vs. Moon; and Bella Bella (IS 233)-Raven vs. tree. The trickster's simple summons to a salmon to jump on shore when he is hungry is used again by Raven in a Tsimshian myth (BBAE 27:53).

The Coeur d'Alene myth, as well as others of the versions discussed above, concludes with Coyote's transformation into a rock. This is a common stylistic device for the final disposal of a transformer among the Thompson and Shuswap. For example, in a myth of the Shuswap (IS 4), the four transformer brothers at the conclusion of their work sit down on the bank of the Fraser River and watch a girl on the opposite side; they remain sitting there until they are transformed into stones.

\section{Story of Lynx}

\section{a. by Tom Miyal}

1. Lynx by looking at chief's daughter impregnates her

2. Baby cries without stopping

3. People hold baby as test of its fatherhood

4. Lynx proves to be the father

5. People stamp Lynx into ground

6. Chief's daughter and baby deserted

7. Magpie and Rabbit return with blankets for baby

8. Lynx revives and smooths himself

9. Chief and his people starve

10. Coyote and Raven return to chief's daughter for food and are choked by her

11. Rabbit and Magpie return, are fed and given much food to take back with them

12. People discover food and decide to return to former home

13. Damages are paid to girl by village

14. Bluebird's blue coat is missing

15. Bluebird's coat supplied and accepted 
16. People return to Lynx and plenty

17. Coyote finds nothing but fat and bones in his house; catches two fawns when the others catch deer

Lynx lived with his grandmother not far from the other people. The chief had a daughter. One night the people went to the chief's house to a council. Lynx climbed the poles of the chief's house and saw his daughter sleeping. He thought, as he looked at her, "Soon she will have a baby." Not long after she had a baby. The chief asked, "Whose child is it?" "I don't know."

The baby cried all the time. At last the chief said, "If the father would hold his baby it would stop crying." Raven said, "It's my grandchild." "If he stops crying when you take him, it is your child." Raven took the baby but it kept on crying. Coyote said, "Give it to me. It's my grandchild." He took it but it kept on crying. No one could quiet it. Everyone had held it but Lynx who was not there at the time. The chief said, "Go call Lynx."

Lynx told his grandmother, "Come sit on my back. It's my child, When the people find it out they will kill me. As soon as I take him I will pass him to you. Then you run off with him."

They did that. Lynx took his grandmother on his back and sat right near the door. The chief said, "Hand the baby around again. Let everyone take him." Each one wanted the child but he would not stop crying, "uxa, uxa." When Lynx took him he stopped crying and laughed, "gaw!"

"Let's try once more," ordered the chief, but no one could quiet the child. When it came Lynx's turn again he let out his claws and clawed his baby. But no! It stopped crying. The chief said, "We can't allow this. What shall we do? Shall we stamp on him?"

Lynx threw the baby to his grandmother. Coyote took Lynx by the neck, threw him down in the middle of the floor, and they all stamped on him until he sank so far into the ground that only his fur showed. Then the chief said, "Leave him there! Let none of you take pity on my daughter. We will leave her here to die." Everyone left. Only the girl and her baby were there. She sat by the fire. Then Magpie turned back. "Where are you going?" "I forgot something which I need." "Hurry then."

Magpie went back, took off his blanket, threw it down and cried, "It is for the baby."

Rabbit also pretended he had forgotten something and took his blanket back for the baby. The girl just sat there and cried. She was cold and hungry. Then way off she heard singing. It kept getting nearer 
and nearer. She found it was Lynx. As he sang his fur began to stand up. He slowly rose out of the ground. He got up. He smoothed his body down to his ankles and wrists and up as far as his neck. As he was smoothing his head the girl went and took hold of him, "Don't do that ! I am nearly frozen." "You will always think me ugly when you look at me. Let me fix up my body. Then I'll look nice." He smoothed his feet. They were nice. She said, "You're good enough." "You will look at me and think me ugly." "No, you are all right as you are." So he said, "All right. I'll make our house. Let me go."

He made a good house and built a fire. He killed deer. They always had plenty to eat.

The people who had left made camp. They hunted. Magpie and Rabbit each killed a fawn but the rest of the men caught nothing. After a time they were all starving. Finally the chief said, "I guess someone better go and see Lynx." "I'll go," volunteered Coyote.

He went. He saw there was a fire in the house. The little boy was now big enough to play about. His mother had given him a tallow disk to roll. Coyote watched where it stopped and waited there. When the child rolled it again it stopped near Coyote. He grabbed it with his mouth. The boy chased him and howled, "He is going to eat my plaything." His mother came out. "What is the matter?" "Coyote is trying to eat my plaything."

She caught Coyote and choked him. Then she tore the fat out of his mouth and gave it to the boy. When Coyote got back home he said nothing, no matter what the people asked him. Some days afterward Raven said, "I'll take my turn. I'll go to see if we can get something to eat from Lynx." The same thing happened to him. When the woman choked him his eyes turned white. He lay there. Finally he got up and went back, but would answer no questions. "Why are your eyes so white?" "I don't know."

The next morning Rabbit said to Magpie with whom he lived. "Let us go to see Lynx." They came to Lynx's house. They saw many deer lights hanging outside. They wanted to take them. The woman came out. "Come in," she said. She gave them a lot to eat. "We and all our people are starving," they told her. "Why didn't you come here? Come whenever you want to." They ate and ate. "Eat until you have enough," she said.

"No, we are saving some for our children." "That is not necessary. Eat until it is all gone. Then you will have something to take back to your children anyhow." They ate it all. "I guess we'll go now."

She fixed a pack of food for them to take back. "When you get back 
don't grudge it. Put it all down and let your children eat their fill. Then if there is any left, dry it."

They took the food home. Rabbit's children ate, $t s^{\prime} a t s^{\prime} a t s^{\prime} a$, and Magpie's, aninin. The people asked, "Why do they make that noise? They never do that other times." "Maybe they are dying and eating each other."

Lynx's wife had given Magpie and Rabbit strips of dried fat to take home. This was the choicest food one could offer. The Rabbits were chewing these strips with one side of the mouth and pine moss with the other so that if the people should look in they should not see they had meat. A person went over and peeped in at the door. "I don't know what it is. Maybe they are choking."

The people went to bed. The next morning Rabbit and Magpie left again. The people said, "They have no fire. Go see what is the matter. Maybe they all died." Raven said, "I'll go."

He flew over. "tcar tcar tcar" the people heard as if something were being caught. He went in. Then the chief said, "Go see. If anyone died Raven is probably picking out his eyes."

The man who peeped in saw that Raven was eating meat. The chief said, "Take it from him and bring it to me." They brought it over. "Come, we'll all have a little."

The people all came to the chief's house. The chief cut the meat very small. Each person had a bite. "Now we'll pay damages to my. daughter. We'll take her some presents. Each of you put something in this blanket," ordered the chief. They contributed cloth, handkerchiefs, a big pile of valuables of every kind they had. "Take it to her and say it is from her father. He wants to come back. All his people are starving."

The people took the blanket full of valuables over to Lynx's home. The woman looked at them when they came in and turned away. Lynx tried to be polite, "So you got here," he said. They put down the bundle. "That is what your father sent you. Now I guess we must go back." No one said a word. Lynx thought, "It's up to the woman. Whatever she thinks will be all right." His wife said nothing. Finally she got up and untied the bundle. "No! It is not there, Bluebird's coat of blue," she said.

The people picked up the bundle and took it back to the chief. "Your child said, "No, I won't accept it. Bluebird's coat is not there." "Go call Bluebird."

The girl said to her husband, "They are unreasonable to offer me what they don't want themselves."

The chief sent Bluebird's coat over. The men laid it down. "Here is what you want," they said. She laughed. "Go tell them to come in," she 
said. They went in and saw the house full of meat. The people were fed and went home. Coyote came in. "Just bones," he said, as he untied the sack he had brought back with him. He untied another and found it full of fat. He ran to the chief and complained, "I got nothing but bones and fat." He was told, "I can't help it. Tomorrow we'll get fresh meat."

The next day the people led by Lynx went hunting. They impounded the deer. Each person caught two. Coyote had two fawns.

\section{b. by Dorothy Nicodemus}

The numbers of the abstract refer to corresponding numbers in the analysis of version a.; only the incidents which differ are mentioned.

1. Lynx marries the chief's daughter without permission

5. Coyote, Raven and Grizzly stamp on Lynx

7. Magpie and Rabbit step lightly

9. Magpie and Rabbit rewarded with fawn while others starve

10. Raven chokes on grease stolen from Rabbit and Magpie; Lynx's wife beats Coyote and Raven

14. Bluebird's blue necklace is not among gifts offered to pay for desertion

15. Bluebird's necklace supplied and accepted

17. Coyote gets only bones and scraps; Raven gets nothing but heads

There was a village of which Eagle was chief. He had a daughter. Lynx took her for his wife without the chief's permission. She had a child. The chief became angry. "I wonder whose child it is," he said. Coyote said, "It must be the child of my first-born."

The child cried all the time. The chief said, "If one of you picks it up and it stops crying it will show he is the father."

The people passed it around. When it came to Coyote, he said caressingly, "My daughter's child. ${ }^{1}$ You poor thing! My daughter's child." But no! It kept on crying. Then the chief said, "Is everyone here? No one is missing. My! Lynx is not here. Go call him." Someone went to call him. He refused to come. Then the chief said, "Go call him again. If he says 'No' again tie him up." Then Lynx went reluctantly with them.

The chief ordered the child to be passed around again. When it came to Coyote he said, "My poor little daughter's child, sh! sh !" But it did no good. Coyote passed the baby to Lynx. He took hold of it under the arms driving in his claws but even then it nearly stopped. As he quickly passed it on the people looked up in surprise. It started again wä́ä w wä $\ddot{a} !$

Right behind Lynx sat his grandmother. The baby was passed around

${ }^{1}$ This is very funny showing that Coyote did not know the proper kinterm. He should have said, "My son's child." 
again. Now it was crying less; it was only sobbing, "uxa uxa!" It came to Coyote but his caresses started it again. Then it came to Lynx and stopped altogether. Lynx threw it to his grandmother who ran to her home with it. The chief said, "Go get him. Lay him down in the middle of the house and jump on him."

Coyote and Raven were the first to grab Lynx. They put him in the center of the house and the chief gave the word to start. Grizzly was the first to jump on him. As the people stamped on him Lynx gradually sank into the earth. Coyote jumped from as high a position as he could. Finally nothing but limp fur was left of Lynx. Then they all left the girl there by order of the chief and set out for a new camp.

The girl sat there sadly watching the corpse of Lynx. One morning she heard a song which came faintly from a long distance. As it came nearer and nearer she realized it was Lynx singing. Soon she saw his fur begin to stand up and then his ears and body emerged from the dirt. Then his head came up and finally he jumped up. He sat down. The girl watched him. He smoothed himself as far as his wrists. He smoothed his legs to the ankles. That is why his feet now have long hair. Then he smoothed his body as far as his neck. That is why his face is not smooth, but looks "gathered up." That is also why he has no nose. Just as he was smoothing himself between the neck and chin the woman ran up to him and said, "Stop it now, I am lonesome." "But I might be ugly." "All right. I don't care if you are." So he went to his house and brought all his meat over. He had a very large amount.

Those who had left Lynx and the girl hunted but had bad luck. They tried to corral the deer but got nothing. Magpie and Rabbit had stepped as lightly as possible on Lynx and they each secured a fawn as a reward. As they took it home the woman saw them. "Rabbit and Magpie got lots of deer," the woman reported. At last all of the people became very hungry. Rabbit and Magpie said, "Let's go see Lynx." When they arrived at Lynx's house they were rewarded with much food and grease. He gave them food for their children and said, "Tomorrow you may move back here and stay with us."

That night the children of Rabbit and Magpie made much noise, the Magpie children on'an'an, the Rabbit children ots'ats'ats'at. The chief was alarmed. "You better go look. Maybe they are dying of starvation." The children were busily eating. From one side of each mouth hung a strip of meat and grease which Lynx had given their parents and from the other side hung a strip of moss. The messengers did not see the grease but only the moss, and reported to the chief. "Just moss the poor things are trying to eat." 
Then everything was quiet and the chief thought. "Perhaps they have died," so he sent someone to investigate. Raven however had gone without orders. As he flew over the house he saw something white inside. He swooped down and found grease. When he ate it he choked on it.

The chief suspected Raven and said to someone, "Go! I suppose he'll be picking out the eyes of the dead if we don't watch out." The people went and pulled the fat out of Raven's throat. They divided it and each had a very small piece. When Coyote and Raven came up to Lynx's house his wife beat them on the head and killed them.

The chief now ordered the people to contribute their most valuable possessions to compensate for the desertion of his daughter. "Bring your valuables. We are going to pay damages," he said. "Mine are the best," boasted Coyote. They took the best they had, tied them in a blanket and about ten of them took it to Lynx's house and deposited it there. Neither Lynx nor the woman paid any attention to them. "We have laid our valuables on a blanket so we will all feel better toward one another," they said to the woman.

The woman got up and untied the bundle. She looked at the contributions of Coyote, Raven and the others. One thing was missing. It was Bluebird's necklace. Because it was blue it was very nice. "No," decided the woman, "as long as Bluebird's necklace is not part of the payment we cannot make up." The people took the payment back to the Chief and reported, "No! She says, "Bluebird has not brought his contribution." " "Go call him." Bluebird was asked, "Why didn't you put your beads in?" "No, I didn't think they'd care for them. They are so ugly." So he gave them. When the woman saw them she took them, "My! Thank you!" she said. "You may come back here to live. Come back to live in your old houses. Each one will be full of meat."

Coyote however found only bones and undesirable scraps in his house and Raven found nothing but heads.

This is the end of the road.

Desertion episodes following the general outline of the Coeur d'Alene myth-all the people leave the condemned ones; a kind person conceals fire and food; the deserted ones prosper; the starving tribe returns-are widely distributed in the mythology of other tribes. In a number of instances moreover the motivation for the desertion in question duplicates that of the Coeur d'Alene myth, namely, the impregnation of a girl by Lynx (or Wildcat). The resultant abandonment in each of the comparable versions follows the general pattern outlined for the Coeur d'Alene story with the exception of a payment of damages. A listing of 
the myth bodies in which Lynx $(1-3)^{1}$ or Wildcat $(4,5,6)^{1}$ elements are found follows. Minor variations may be found: in the method of the girl's impregnation-Lynx (Wildcat) spits upon the girl, urinates down the house-post, puts hair upon the ground, the girl scratches herself with Wildcat's cane; in the choice of the contest to establish the father's identity - the father holds the child, the father engages in a shooting contest, the child selects a bow and arrows; in the procedure followed in Lynx's revival-the girl doctors Lynx but he is left with an ugly face, the girl steps over Lynx four times and strokes his head, Wildcat bathes the scabs from his body, the girl peeks at Wildcat in the sweat lodge the fourth day and he is obliged to emerge with his face still shriveled; and in the selection of the kind characters-Magpie, Rabbit, Crow.

Shuswap (MAM 4:684; ARBAE 31 :950; IS 9).

Thompson. Lynx spits on a girl and impregnates her because of his displeasure with her grandmother, Mountain Sheep (her aunt Elk) who concealed her from all the young men (a continuation of the Thompson narrative of The Girls who stole Dentalia, cp. tale 24 this work). (MAFLS 6:36; $11: 12$; MAM 12:216, 300.)

Kutenai. Two grown sons of Lynx and Doe prove best qualified among the contestants for the role of the sun and the moon. (BBAE 59:287; VBGA 23:163 and cp. tale 1 this work.)

Nez Percé (MAFLS $11: 195)$.

Sanpoil (JAFL 46:138).

Cowlitz (MAFLS $27: 193$ ).

In a second Kutenai version (Dyer ms.) the story may again be found practically intact, despite the fact that it is interwoven in this instance into the narrative of the girls who stole dentalia (cp. tale 24). A similar combination has been referred to above in the case of the Thompson Lynx myth but, whereas the Thompson merely juxtapose the episodes of the two stories, the Kutenai combine them into an inseparable whole.

Young Doe is kept hidden from the people by Frog and her grandson, Rabbit; Lynx discovers the bark upon which Young Doe is accustomed to urinate and makes medicine over it; he hides a teepee, food, clothing and a coal; Young Doe gives birth to a child; the baby cries without stopping; the men go in to the baby as a test of its fatherhood; Lynx proves to be the father; the people kill him and desert Young Doe and her child; Magpie gives Doe a cover for the baby; Lynx revives and sends Doe for the hidden supplies; he kills many deer; the other people starve; Magpie returns, breaks off a piece of the baby's tallow, and is invited in to eat; he is sent back to fetch the rest of the people ; Lynx's son is kidnapped by Owl and Toad but, with the help of her dog, Grizzly Bear, Young Doe recovers him; she and Lynx have another son; the two boys become the sun and the moon (cp. this work tales 1 and 2).

${ }^{1}$ These numbers refer to the numbers of the elements in the abstracts. 
The Haida, Tsimshian and Chinook likewise have narratives of the desertion of a man and a woman to whose union the people object which again follow the same general Coeur d'Alene outline though they are not concerned with Lynx or Wildcat.

Among the Haida a girl and her lover who has a bad reputation are deserted; Magpie returns to the deserted ones and is given fat to take back to her children; Raven discovers it, returns and steals the deserted child's ball of fat; he is thrown into his cellar amidst hooves and ears, as is Coyote; the rest of the people return to plenty (MAM 14:368).

In the Tsimshian myth the chief's daughter and the poor boy who has won her in a contest at knocking down a copper and shooting a white bear are deserted in shame; the deserted boy kills a frog and gets supernatural power; the princess marries the boy; a man and his slaves sent by the chief are fed; the chief returns with his people; the boy becomes a chief; he goes into the sea in his frog blanket (BBAE $27: 145$ ).

In the Chinook story a boy and his sister are deserted when the girl is impregnated unknowingly by water dripping from her hair; supernatural people send a whale in to the deserted one's beach; Crow and Robin are fed and return to live with the brother and sister; Bluejay leads the people back; the fifth day the party gets past gales, but is surrounded by snow; upon receiving the hand of the chief's daughter in marriage the deserted youth allows the people to reach their homes (BBAE 20:51).

Stories of the desertion of one person because of disobedience, disease, or the like following the same general desertion outline despite their dissimilar motivation are found among the Krwakiutl;

A chief's daughter is deserted by her tribe when she eats sea-eggs out on the rocks; the princess catches the prince of Chief Wealthiest in her salmon-trap for a husband and becomes wealthy; she dispatches gull with blubber for her kind grandmother, who is discovered eating it; the tribe gathers mussels as damages for the princess; the girl's husband gives the chief food which runs out his anus; the girl drives her father out in shame (Kwakintl CUCA 2:247; ARBAE 31:950; Newettee IS 180).

A chief's son feeds the people's salmon to eagles in exchange for feathers; the boy, his grandmother and slave are deserted when provisions run short; the eagles supply the boy with food; the boy drops a piece of meat into a canoe; he feeds investigators sent by the chief; one takes meat home secretly and his child is discovered choking on it; the people embark for their former home; the boy finally allows them to land; he becomes chief (Tsimshian BBAE 27:170).

Led by Coyote, the people desert a bad boy; the boy finds fire and seeds left him by his grandmother; he fishes up a sea monster woman who marries him; the two fill many lodges with her goods; the magpies visit and are fed; their children are 
heard eating the salmon they have brought back; Coyote returns to the old camp site and transfers much goods from other lodges into his own; he fetches back the rest of the people ( $\mathrm{Nez}$ Percé CUCA $25: 356$ ).

Even in such desertion stories as have a setting entirely different from that of the Coeur d'Alene Lynx story, the standard stylistic features consistently appear-someone is secretly kind to the deserted one, the deserted one prospers, he and his people are reunited, the kind are rewarded, the cruel punished. Such parallels may be found in a Tsimshian (IS 301) or a Rivers Inlet myth (IS 229).

Each of the myths included above has been discussed from the point of view of its parallelism to the Coeur d'Alene myth taken as a whole. Individual episodes in the desertion story however are frequently singled out to become of themselves the central theme for complete stories.

The father test is the subject of Tlingit, Nootka and Kwakiutl myths.

A woman dreams she is married and gives birth to a child; the child cries without stopping; the child's grandfather assembles all the men of the village, then all those who live in trees, seeking its father among them; the child crawls up to an old man at the door and stops crying; the old man marries the girl (Tlingit BBAE $39: 238)$.

Mink gives a piece of the tar he is chewing to a girl; she gives birth to a child; the girl's father has all the men step one after the other before his daughter and the child; the child will have none of them until Mink appears and takes it up; thus the people learn Mink is the father (the child announces Born to be the Sun [Mink] is its father) (Nootka IS 108; Kwakiutl CUCA $2: 495$ ).

Raven's theft of children's food is the theme of Tsimshian (ARBAE $31: 75$ ) ; Tlingit (BBAE 39:5, 92; ARBAE $31: 940$ ); and Haida myths (BBAE 29:129; MAM 8:183, 208; MAM 14:298; IS 309; ARBAE $31: 940)$. These stories are practically uniform: Raven sees children (Crows) playing catch with pieces of seal fat or blubber, joins in their game and eats the fat. In one Tsimshian version the children take revenge upon Raven; they tell him they dive down from a tree to obtain the blubber; he dives and is killed (BBAE $27: 42$ ).

Such other minor stylistic devices of the desertion story, as the discovery of food in the village as a result of a child's choking over it, may be used by narrators in any variety of myth. The food discovery has already been met with, for example, in the Thompson story of Coyote's theft of his daughter-in-law (MAFLS 6:21; cp. this work tale 4) where Raven's children are heard quarreling over the fat which Raven has obtained from Coyote's son, who had collected all the deer in one spot for his faithful wife and himself ; upon the discovery the starving people 
return to Coyote's son and are fed. In conclusion an additional typical example may be cited from the mythology of the Tsimshian.

During a famine in the village the young chief takes his slaves out and gets food for them; a slave child chokes on the food which his mother has secretly brought back to him; the chief's uncle discovers the food; the slave tells the uncle of the young chief's extraordinary powers (IS 298).

\section{War between Land and Water People}

He who can break an elk antler is to have the chief's daughter in marriage

Salmon is successful

War between the Land and Water People

Wolves steal woman from Salmon

Rattlesnake traps Salmon who escapes

Salmon burns Rattlesnake's house in revenge

Meadowlark helps Salmon

Salmon kills four Wolves; youngest Wolf escapes

Two chiefs, Reserved and Quiet, go hunting

Reserved kills Wolf

A chief had a daughter. He took an elk antler and said, "If any of you can break this he may have my daughter in marriage." Coyote said, "My firstborn will be the one to break it." Grizzly Bear said, "I will be the first to break it." "Rrrr," he growled as he tried it. No, he did not succeed. All tried. The Water animals tried but they failed. Then the chief said, "Come again tomorrow and try." All came, but had no success. Salmon was not there. Once more the chief summoned them and this time Salmon came. They all tried in vain. Then someone said to Salmon, "You try it."

He took it and dropped oil in the curve of the horn. It nearly broke. The next oldest Salmon and the next tried. The youngest broke it. It crumpled in pieces. The youngest Salmon took the woman by the arm and ran. Then the Water People and the Land People began to fight. Salmon was headed off because he took the woman. The three brothers were killed. The oldest had the woman under his arm. Just as he reached the water the Wolves caught the woman. They were pierced by the arrows of the Water People-Turtle, Frog and Snake. The Land Animals-Bluejay, a scolding bird, and one with a white head--were brave and fierce.

Frog said, "You can't spear me. Even if you should shoot ahead of me in the water I do not think you could get me." The Land Animals however were very fierce and pierced him through. Snake said, "If you shoot often at the side of me you might be able to get me." 
He was shot in many places and died. Salmon who was wounded in many places when he jumped into the water was just barely conscious. Then they "phoned" upriver to Rattlesnake to make a weir. After he finished it he kept watch. Once as he looked at it he saw Salmon swimming in the trap. He shot him in the head. Ever since there has been an arrowpoint on Salmon's head. Rattlesnake took Salmon and clasped him to his chest but he slipped away into the water. Then it was useless to try again to get him. So he "phoned" downriver to Mink and Mouse to search in a canoe. For two days they searched and found only bones. They brought them home. They made torches of pitch and put them in the canoe. The canoe was tipped over. Mouse stole fish-grease, rubbed Salmon, stepped over him and he became alive.

For two weeks Salmon stayed there. Then he went upriver to take revenge on Rattlesnake. When he came to Rattlesnake's house he heard him dancing the war dance, but when he went in Rattlesnake pretended to be crying. "I have been mourning ever since I heard you were gone," he said. Salmon said, "You are wasting your tears. I wish to have a spark so I can melt pitch to mend my canoe." "All right take one."

Salmon took the spark and burned Rattlesnake's house which was made of grass. He died screaming in the flames. Salmon knew where the woman had been taken. He went ashore there. He wandered at random crying about his tribe. Suddenly he saw a nice little stick. He stepped on it, "änininin, you broke my leg." (It was Meadowlark who spoke in Spokan.) "Oh I'm sorry, you put it across the road right in my way." He restored Meadowlark's leg and she went with him to Wolf's house. There was another Meadowlark at Wolf's house ("He must have turned against his kind," said the interpreter). He killed this Meadowlark and the real one sat in her place. The woman was tied with a ball and chain. The Wolves were gone. Salmon went to the roof of the house and waited with his sword ready.

Soon Wolf's song was heard, "max, max, that which slid on the roof of the house stinks; it must be Salmon." (This was spoken in Spokan.) The Meadowlark went out and said, "Come, the woman you stole is hungry." Four times Wolf came up to the door and jumped back. The fourth time Salmon raised his sword and cut Wolf in two. Mouse, Louse and another pest which the Coeur d'Alene used to have (perhaps flea) licked his blood. Then all died except the youngest Wolf. His arm was struck but only half of his body was injured. Salmon and Meadowlark came back. Salmon brought back the woman. Because Wolf was a man-eater the people were afraid of him. They had a council. There were two chiefs who were pleasant, even jolly, but who did not talk much. One was called Reserved and the other Quiet. They said, "At 
night we will go hunting. You shout and say, 'Reserved is gone, Quiet is gone." "

The two chiefs went away. Wolf heard the people shout, "The chiefs are gone." Wolf knew the chiefs were fat (he could tell by their names!). He tracked them to the edge of a cliff where they had shot an elk and were eating. Quiet saw Wolf crawling up. He said, "Get out your weapon." Reserved stopped eating, he was not afraid but his companion was. Wolf was just about to strike but Quiet said, "Take your weapon in hand." "Keep on eating and be quiet," the other ordered. He watched Wolf who came closer and closer. Just as he was about to strike Reserved growled and struck first. Wolf fell over the cliff. Since that time Wolves are small and they are no longer maneaters. That is the end.

Closely allied myths with but minor variations in detail occur in the mythology of the Chinook, Sanpoil, Nez Percé, Upper Chehalis, Thompson and Quinault.

A chief's daughter is to be given to the one who breaks a pair of elk antlers; Salmon succeeds; Coyote shoots Salmon with a magic arrow; the five Wolves steal the woman; the people eat the salmon; Crow nurses a salmon egg into a salmon; Salmon names Coyote and Badger and burns their house; in disguise he makes flint arrowheads for the wolves, keeping five for himself; he shoots each wolf while drinking at the well; he burns the house and leaves with the woman (Chinook BBAE $20: 77$ ).

Salmon helps Spider catch salmon; Salmon twists four pieces of elk horn to win the chief's daughter; Rattlesnake uses his fang as an arrowhead to hit Salmon (Salmon dies; Rattlesnake declares him a common salmon); floating off in his canoe, Salmon throws his wife ashore for talking too much; Wolf and his brother carry her off ; Salmon returns in the spring; Spider advises him; Salmon avenges himself upon Whitefish and Rattlesnake; Whitefish is to be speared by people, Rattlesnake is not to kill from a distance; Salmon's wife gives him a flint knife; Salmon kills the two Wolves at the spring; Salmon returns to his wife each summer (Sanpoil JAFL 46:143).

Salmon catches a glimpse of a girl in the menstruation hut; she goes away with him; Rattlesnake and Spider refuse to help the wolves obtain the girl; Stubby Rattlesnake bites Salmon to death and the wolves mash him; when some of his blood splashes into the water, Salmon revives; the wolves carry off the girl; Salmon sends fish to Old Man Spider who is kind to him; he drives the fish away from an unkind man; Meadowlark gives Salmon advice; Salmon spares Rattlesnake's life in return for his set of teeth and information about the wolves; the girl hides Salmon at the wolves' place; Salmon kills four wolves, the youngest escapes; the girl turns into a salmon ( $N e z$ Percé CUCA $25: 222$ ). 
Spring Salmon throws a princess in a wrestling match, after Wolf, Cougar, Bear, Wildcat, Hawk, Owl, Eagle and Dark Eagle have failed; Wolf kills Spring Salmon; an egg from the body grows into Spring Salmon again; Spring Salmon kills the Skunks for making fun of him; he makes arrowheads for the five Wolves, keeping five for himself; he shoots four of the Wolves, the youngest escapes; thus there are wolves today; Spring Salmon dies in his canoe while returning home with his wife (Upper Chehalis MAFLS 27:110).

Humpback Salmon steals a girl from the Lytton people for a wife; the Animals steal Humpback Salmon's wife from the Fish people; the Fishes make war upon the Animals and are vanquished; Dog Salmon escapes and never leaves the lower country; Humpback Salmon's son attacks the Animals, and takes his mother back home (Thompson MAM 12:231).

Five Wolves kill the man who is strong enough to break an elk horn and carry off his wife; the man revives and pursues them; he stays in the Wolves' house disguised as his wife's father; he kills each Wolf in turn at the spring; he takes his wife back home (Quinault MAM 4:120).

The above six versions correspond closely to the Coeur d'Alene myth with the exception of the final extermination of the last wolf by the chiefs, Reserved and Quiet. In the Nez Percé and Upper Chehalis myths, in which Salmon fails to kill all the wolves, no pursuit is made of the escaping youngest wolf ; according to the Upper Chehalis, in fact, it is because of this that there are wolves today.

\section{Dog Husband}

Girl gets husband secretly

Girl's older sister taunts her about his looks

Ugly husband catches ermine

Is transformed into a handsome man

Girl's older sister abuses dogs, her sister's husband's kin

She is left alone with dogs

Dogs become men with suits trimmed in broken beads

Girl deserted with her two dog children

She goes for food, see tracks of dog and baby

Spies on her dog children and finds one is dog, the other little girl who abuses dog Mother defends dog and lives with daughter and dog son

Two sisters lived together. The elder was the wife of Eagle who was the chief of the village. The younger girl got a husband. Her sister heard that she had a husband. She thought, "I'll go see my brother-inlaw." She went there and saw her sister sitting with an ugly man. She said to her, "Why did you choose such a homely man? There are plenty of good-looking ones." He was very old. He was blind. He could not see the people, the Lynxes, Fishers or anyone. The younger sister said, 
"Shut up! Go back to your old eagle. Actually he has a long crooked nose. That's the kind you chose for your husband." The older girl went home.

Across the river an ermine was seen on a bush. Coyote shouted, "Go set a trap for ermine." All the people went and set traps and watched them but ermine ran right through their traps without getting caught. The people came back. Then the younger sister led her husband out to try trapping. When they were seen someone remarked, "If even those handsome fellows can't catch ermine, how can an old blind man expect to succeed." They said nothing. They went past the place where the other traps were set. He set one and his wife led him back home, but they had only gone as far as the open country where ermine was caught biting at the trap.

Coyote cried out, "What does that old duffer think he is going to do?" The people ran out to take the ermine. The wife said, "Leave it alone. $\mathrm{He}$ is going to use it for his eyes." They gave it to her. The next day the older sister said to her, "What are you going to use that for, that which you took from those boys?" The younger sister paid no attention to her. She went in. Night came. Morning came. The older sister thought, "I'll go and reason with my sister."

She went into her house, but saw her sitting by a handsome man. She did not say a word. The wife was combing his hair and fixing it nice. Her sister said, "You're hurting him, let me comb him." She came up closer to the man. She kept edging closer and closer and said, "Give me that comb. I'll comb him myself." Her sister hit her hands with the comb. "Go to your eagle! Fix his hair if you want a man." But no, she sat still. Again she was told, "Go back to your eagle." She went back. Soon she came again. At night they slept. The wife said to her husband, "Come let's go back to your people."

They came to the home of the old men's relatives. The older sister found out that they were all dogs. She saw her sister sitting in the house with dogs all around her. The younger sister told the elder not to come near but to sit far away from them. But no! she wanted to sit close to them. At night they ate some kind of meat. All ate, the younger sister, her husband and all the dogs. Eagle's wife alone did not eat it. Her sister said, "Eat!" "Why should I eat like a dog?"

A dog lay down beside her. She hit it. "Stop that!" warned her younger sister, but she did not listen to her. At night the dogs, which were all spotted, went to sleep. Eagle's wife sat up and kept hold of a stick with which she hit the dogs. "Lie down and go to sleep!" her sister told her. At last she went to sleep. The woman and her husband left her. When she woke she was crowded upon by dogs. She jumped up 
and hit them. They ran off. The younger sister was gone. Eagle's wife did not know where to go. She cried. She stayed. At night she slept again and the spotted dogs all came back. She hit at them with a stick but they crowded her.

When she woke she heard something which sounded like people talking. They were not far off. They were laughing. "My clothes are all worn out because I was beaten. The beads are all broken and lost," said one. Another said, "My necklace is worn because I was beaten so." They laughed again. A third said, "My bracelet is in shreds. She beat me up terribly." "My earrings are ruined," said another and they laughed again.

Suddenly they were gone. The girl got up and looked. She saw they had a fire and men were standing around it. All their clothes, their moccasins and trousers were embroidered in beads. She went in and thought, "They are people. I will not beat them anymore."

She lay down. They went into the sweathouse. By daybreak all was quiet. She thought, "I'll go see." Where the men had been standing there were only broken white beads. ${ }^{1}$ She went back in and cried. The dogs were gone; they were people. She stayed there alone and cried. After some time she gave birth to children. They were dogs. She thought, "I won't leave them, I'll take care of them." She covered them and warmed them.

In the morning she would go out, travel about and come back. She would feed them and go out again. Once when she went to the fireplace she saw the tracks of little people with those of the puppies. She thought, "Someone must have been here who had a baby."

The next day she went out again. When she came back she saw the baby tracks with those of the dog and thought, "Why did that person come with its dog?" She looked at her own pups and saw they were all right. At last she decided to spy on them. She went into a corner and covered herself with a blanket leaving only a hole just big enough for eyes. There she kept watch. She heard her dogs say, "It's about time for us to play." One, a little girl, said, "I'll see where our mother is." She went out. Soon she came back and said, "It's all right. She's gone."

The mother saw her lead a little dog around the fire by a rope which was fastened around his neck. She said to him in her language, "tcinuninu'nununi" and he answered in his language, "tcitcitcinunu." She hit him. As they were running she said it again and he answered. She hit him again. Then their mother jumped up. She took hold of the girl and said, "Stop!" She answered, "No, I'm very lonesome. I'm trying to

1 The spots on the dogs were beads. 
teach him to be a little person too." "No! It will be all right this way. He will be our dog, but we will be kind to him." Then the mother lived with her daughter who was a person and her son who was a dog. That is all that I know!

The end of the trail.

The Coeur d'Alene setting for the widely distributed Dog Husband narrative was not found duplicated in the territory covered by this analysis. The Coeur d'Alene combine a Deformed Transformed episode with the Dog Husband one and use the former as the background for the latter, which further does not terminate in any decisive ending as in the Dog Husband stories of other tribes.

Comparable parallels to the acceptance of an ugly husband who forthwith demonstrates great power and becomes transformed in due course into a handsome man to the jealousy of all the people are found in the form of distinct myths with no association with Dog Husband episodes in the mythology of the Thompson, Sahaptin, Okanagon and Chilcotin tribes. The Thompson and Chilcotin also have independent Dog Husband stories.

A woman marries Tsa'au'z, who is dressed in a garment of sores; the people taunt her and him; at night he puts on clothes covered with dentalia, which drop off making his parents-in-law rich; he kicks down four trees and supplies all the houses with wood; he is successful on the hunt and carries home in his gloves meat which fills the houses; his brothers-in-law fail to destroy his garment of sores by burning it; the garment turns into fog (his wife burns up his sore skin); he returns home handsome (Thompson MAM $12: 267,373$; MAFLS 11 :29).

In the Sahaptin version the Coeur d'Alene element of the disagreement between the sisters about the younger's husband is met with:

Walaetitsa, ugly and dirty, wins the shooting contest in which Eagle's two daughters are at stake; the younger girl goes with Walaetitsa, the elder goes to Raven; the elder girl taunts the younger; Walaetitsa becomes clean and handsome and the most successful hunter; Raven is vanquished (MAFLS $11: 159$ ).

Sun, disguised as a dirty boy, comes to earth, accompanied by his sister, Star, who masquerades as a feeble old woman, in order to win a chief's two daughters; Dirty Boy wins a shooting and a hunting contest; the chief's younger daughter waits upon him; Sun and Star resume their beautiful forms; Sun supplies the starving tribe with much food from the hunt (Okanagon MAFLS $11: 85$ ).

In each of the above versions emphasis is placed upon the scorn with which the deformed youth and his wife are regarded and the great powers which he in turn reveals, as well as upon the faithfulness of his 
wife, who is ultimately rewarded by having the most handsome husband. In the Chilcotin version, on the other hand, the ugly, weak boy pulled out of the water makes his way alone and marries the two sisters who rescue him only after Raven has destroyed his slime shirt. In his unsightly disguise he locates wood and supplies snowshoes for the tribe and kills many caribou when the other hunters return empty-handed (MAM 4:37).

The Dog Husband episode in its wide distribution usually appears in a highly uniform, well-defined form; the Coeur d'Alene treatment fits into this general grouping, although it shows more deviation than usual. The general outline for the story everywhere includes: A girl who refuses suitors is impregnated by her own or her father's dog and gives birth to pups. The people desert the girl. The mother discovers the pups are human children and burns their dog-skins. The boys become great hunters. The starving tribe returns. (The desertion episode follows the pattern of the Coeur d'Alene desertion in the "Story of Lynx," tale 9, with its stylistic elements of reward for those who help the deserted ones and punishment for those who recommend the desertion and show cruelty.) There follows a list of the tribes which tell the Dog Husband story; only significant major variations have been specially noted:

Quileute-eight dog children (CUCA 12:131, 137).

Thompson-four dog children or three male pups, one female; the female pup escapes the medicine thrown at it and remains a dog (MAFLS 6:62; MAM 12:354; MAFLS $11: 30$ ).

Lower Fraser River-eleven pups, five male, six female; one black and white female remains a $\operatorname{dog}$; the dog husband who was beaten almost to death is healed and returns to his wife as a great hunter (MAFLS 11:130; six dog children (IS 25).

Kathlamet-a girl sleeps with her bitch; the people kill it and feed her its fat; she begets five male pups, one female (BBAE 26:156).

Tlingit-a woman's husband kills all her children; the woman has a litter of pups by her dog in revenge; the four male pup-skins are burned and they become powerful shamans; the female remains a dog (BBAE 39:100).

\section{Quinault-four male pups, one female (MAM 4:127).}

Chilcotin-three pups; their mother burns their blankets, but their dog father escapes with one-half of his and remains half man, half dog (MAM 4:8).

Ts'ets'a'ut-two male dog children, one female; the girl snatches her dog-skin from the fire and remains a dog (JAFL $10: 37$ ). 
Haida-nine male pups, one female (MAM 8:191).

Nootka-ten dog children; when the people attempt to return to their former home, the ten boys produce a big wind and the people drown; they become islands (IS 114).

Bella Coola-four male dog children, one female; the female remains a dog; in a storm all the returning people except the kind grandmother are drowned (all the people except the woman's parents, brothers and sisters are permitted to return) (IS 264-5).

Yookilta-two of the ten boys slip back into their dog-skins and remain dogs; the death-bringer is waved at the returning tribe and, with the exception of the girl's grandmother who had provided her with coals and food, the people turn into stone (IS 132).

Upper Chehalis-four male pups, one female (MAFLS $27: 96,98$ ) ; five male, one female (MAFLS $27: 99,103$ ).

Humptulip_two female pups, three male; when the five pups become people, their mother declares they shall be a disgrace to their tribe; she beats the old dog, her husband, and leaves with the two girls (MAFLS $27: 328$ ).

Rivers Inlet-the woman marries a bear and has four bear children, two male and two female; she takes off the bear skins of all but the youngest daughter, who goes away into the woods; the mother and her three children return to her people; she rejuvenates her parents and all the old people and distributes much food and skins (IS 227).

Comox-the rejected suitor chews tar and gives the girl a piece to swallow; seven dogs, one female; the girl child snatches her dog coat out of the fire in time to save one corner of it; her left hand remains a dog's paw (IS 93).

\section{The Coeur d'Alene element of the abuse of the dog child by the human} child is encountered in additional myths of the Thompson and Shuswap:

A girl, impregnated by her father's dog, has a male and a female pup; the people are ashamed and leave her; she throws medicine on the pups, striking only the boy; the girl gets into her dog-skin and remains a dog; the mother instructs her son not to beat the dog; the boy disobeys; the dog turns into a golden plover and flies away (Thompson MAM $12: 354$ ).

The children of Fish and Frog visit their grandmother, Grizzly Bear; Grizzly Bear throws medicine at them; the boy takes human form; the girl, barely sprinkled by the herb liquid, becomes a small female dog; the boy thrashes the dog for eating his game; the dog runs away into the mountains (the dog assumes human, fish-bear or chickadee form and runs away to the sky) (Shuswap MAM 4:693; Thompson MAM 12:356). 
The discrepancy between the above Dog Husband versions and the Coeur d'Alene account, all of which have some element of desertion and transformation in common, lies in the abrupt, unorientated conclusion of the Coeur d'Alene myth.

A Wasco myth which does not fit into the typical Dog Husband outline, is abstracted below in conclusion to show its use of the Coeur d'Alene feature of the family of dog-folk.

A woman follows a dog who has stolen her paint; the woman spends the night in a house occupied by dogs; the dogs become men who complain of the woman's slaps; the woman's dog-man guide marries her; accompanied by her husband and her child, she visits her parents; she looks at other men; her husband leaves her (PAES 2:253).

\section{Coyote and Fox Gamble with the Fish}

Coyote teasingly invites Fish to be his guests

Fish arrive, gamble and win

Fish invite Coyote and Fox to gamble in water

Coyote accuses Fox of cheating

Coyote and Fox win and return home

Coyote and his friend, Fox, had a house. Coyote had a daughter. Every day the men went to catch pheasants. They always brought many home. One night after eating Coyote went down to the water. As he sat idly on the bank he saw fish deep in the water. "We ought to be doing something to pass the time. Tell your elders to visit us." The little fish apparently paid no attention to him. "Do you hear? I am talking to you." They said nothing. Coyote went home.

Not long after as he and Fox were sitting quietly at home they heard a sound as of many people approaching. Fox saw ten boats full of people rise to the surface of the water. The little fish had said, "Here, you people! Coyote told us to invite you to come." The grownups answered, "Ah!" Fox went back and announced to Coyote, "Lots of people have come. They say you invited them." "Oh goodness!" replied Coyote, "I was only joking."

The people all came in. The place was crowded. Fish's little boy said. "You said we should come to pass the time. That's why we are here." "Let's have a stickgame." "We have nothing to bet." "You have lots of pheasant tails." Coyote said, "No, they are too high-priced." "Is that too high for you to bet?" "How much do you bet?" "The stripe on the feather will be the stake for each game."' "All right!"

${ }^{1}$ The text here is obscure. The informant did not know the details of gambling and these are technical terms. 
Coyote kept count. They laid out a blanket and a shirt. They played. Coyote and Fox lost. They played again. Again they lost. Then the Fish said, "We must go back. We belong in the water. We are getting too dry. Let us have some contests at our home under the water." "All right!" said Coyote and Fox.

They went back to the water. About two days later Coyote and his daughter got into a boat. "I'll be the first," said Coyote. "No, I want to be first," said his daughter. ${ }^{1}$ Four times the boat with its contents was to go down and come up again. They dived. Coyote nearly died until it came up again. He opened his mouth to complain, but before he could get his breath they had dived again. Each time he was nearly dead.

After they dived the fourth time they came to the land below, the water where the fish lived. There was a very long house there. One of the fish announced, "Coyote has come." They landed. They went in and played the stickgame. Coyote sang out, "He's cheating my friend, Fox," "Be quiet," said his daughter. "It can't be helped. You can't depend on what those animals say."

This time Coyote and Fox won, Fish lost. Then Fish said, "We'll play again, but we want something better to bet. Let's not bet those pheasant tails. Put them away." They laid other things down. Coyote and Fox won again. Then said Coyote, "Let's quit."

They went back to their boat and Coyote and his daughter argued again as to who should get in first. He said, "I'm going to dive first." "No, I'm going to," said his daughter. "First place belongs to me. The fish will make fun of you." "No, it belongs to me." She sat first in the canoe. Each time Coyote came up gasping. They came to their house.

Thus it comes to the end of the road.

Among the large number of gambling myths, in which the loser wins back all he has lost, there is one example in Kutenai mythology of a gambling match between Coyote and Fox on the one side and Salmon on the other. It is a continuation of the Kutenai Coyote-Fox story of the animals who stole the hoop (cp. this work tale 3 ).

Coyote and young Fox lose everything gambling with the Salmon who wish to obtain Coyote's hoop; Fox and young Coyote win everything back and in addition Salmon's younger sister who becomes young Coyote's wife (BBAE 59:151). (The story continues at this point with episodes correlating with those of the Coeur d'Alene Water Monster Woman myth, 27.)

${ }^{1}$ They argued this way because the first in the boat was the first to dive. Coyote always dived flat, then accused the others of holding him back. Consequently his daughter wanted to be first. Since they could not agree, the boat with all its contents dived at once. 


\section{Coyote Marries Squirrel, Sister of Geese}

Squirrel feeds Coyote

Squirrel provides Coyote with teeth

Coyote marries Squirrel

Coyote accompanies four Geese, his brothers-in-law, on hunt

Coyote breaks calling taboo and is dropped by Geese

Squirrel kills three brothers by pointing Coyote's tail at them

Brothers revive, pursue and kill sister

As Coyote was traveling he saw a house and went in. A woman was sitting there. After he had been there a little while she got up and cooked meat. He had a large supply. She gave him some but he could not chew it. He had no teeth. "I'll put it away and eat it later," he said, "I'm too tired now." He lay down and went to sleep, "xwu xwu," he slept well. He had his mouth open. The woman saw he had no teeth. "That's why he didn't eat," she thought.

She hunted the smallest deer teeth she could find and put them into his mouth. He woke up and it felt as if he had teeth. He got up. "Now I'm ready to eat," he announced. He was now able to eat all of the food left over from his meal. At night a man came in, "Oh, my brotherin-law, here you are," he said in greeting. "Yes," said Coyote who was sitting on the eldest brother's mat. He then moved over to the mat of the next oldest. Soon another came in and Coyote moved over onto the next bed. A third time the same thing happened. As the fourth was saying, "My brother-in . . ." the others grabbed him and corrected, "Just like my brother-in-law."

By this time Coyote was pushed up against the woman and thus got a wife, the sister of the men. The men went out every morning and brought back much meat at night. For four days they left Coyote and the woman while they went hunting. The fifth morning Coyote dressed himself to go out and said, "I'm going with you." "No, no, we don't travel by land. You can't go the way we do." The men were geese. "Oh!" said Coyote. The next day however Coyote insisted upon going along. "You'll get in our way," the brothers told him. "I'm going anyway." They came to a big lake. "Here's where we cross. You will have to hang on to us." They flew way up. Then Coyote imitated their call, $u^{\prime} u^{\prime} u^{\prime}$. "Be quiet!" they told him.

They alighted. They hunted. They told Coyote, "You must never take more than two deer. Otherwise it will be too heavy." Coyote got two deer and each of the geese got two. Altogether they had ten. As they were flying over the water again Coyote said, " $u$ ' $u$ '?" They told him to stop, but he kept right on. Then they let go of him. He fell. 
When they got home their sister was lying down. "Why didn't you cook our supper?" they asked. As she did not move or pay any attention they cooked for themselves. The next day the three brothers went hunting, but the youngest stayed home. His sister drew in her mouth with a sucking noise, "Listen!" she said, "Don't look around when I come back. I am going out."

She went to the shore of the lake and searched for Coyote. She saw him floating on the water. She cut him around the nose and down the middle as far as the tail, then she cut the tail right off. She took Coyote's skin along home with her. As she opened the door three of the brothers looked around at her. She made a circular motion with Coyote's tail and they fell dead. Only the youngest was left because he had not looked at her.

He sat there. The sister ran off. After a while the three came to life. "We will kill our sister," they declared. "She must like Coyote."

They took their arrows and tracked her. When they got to the water they lost the trail. "I'm tired," said one and they made camp. They heard a squirrel talking. "Kill him," said the youngest, "so we have something to eat." The squirrel was their sister. Way up in the tree she was standing. "Stop your talking now or we will kill you." Each one went out and warned her, but came back and told the others he had not seen her. Then one said, "They must be lying." So two of them went and saw her. They shot her.

The end of the road.

Parallels to the Coeur d'Alene myth are found for the Sahaptin (MAFLS $11: 145$ ) and the Nez Percé (JAFL $21: 149$; CUCA $25: 331$ ). In these two tribes the sister is not identified with Squirrel, there are five Geese brothers instead of four, and the girl dies when her two surviving younger brothers shoot her in the little finger where she has placed her heart. In all other major particulars however the myths are comparable with the Coeur d'Alene version.

A Kutenai myth starts with the usual story of the Geese and Coyote, but terminates in a Coyote-Trout episode.

Coyote is hungry and enters a tipi; he moves nearer and nearer to the woman occupant, as each of her Goose brothers comes in; he marries the Goose girl; the fourth day he accompanies his brothers-in-law on the hunt; on their return the Goose brother carrying him jerks him off in alarm when the people start shooting at the Geese; Coyote sinks to the bottom of the river and enters Trout's tipi; he marries Trout, imitates the Trout children at stealing bait off the people's hooks, is caught by Fox and changes back into a Coyote (Dyer ms.). 
In a shorter Haida myth the Geese tire of carrying their brother-in-law, Raven, and drop him over the sea; Raven sprinkles sand, lands on Rose Spit, recuperates and travels on (MAM $8: 236$ ).

\section{Coyote Imitates Magpie (Bungling Host)}

Coyote lives near Magpie

Coyote's powers become winter berries

Berries disappear

Magpie dives for fish

Coyote imitates Magpie, drowns

Coyote was living near Magpie who had many children. Coyote himself had five. In the winter they were starving. There was just enough camas left for the children. Coyote went out and consulted his powers. One of them said, "I'm hungry too. I'll be serviceberries, there will be a lot." Coyote went in and said, "Go get the camas. We ought to eat. Then the sack will be absolutely empty."

When he said this his family looked out and saw many serviceberries. Mole, Coyote's wife, shared the camas with Coyote and her own children, as well as with Magpie, his wife and their children. Then there was nothing left.

The next morning all went before breakfast to gather serviceberries. They saw many, but each time there was a good patch Coyote said, "No, don't pick them yet, there will be much better ones." Finally he said, "Now pick here." But there were no berries. Coyote had done this to fool them by means of his powers.

Then Mole and Mrs. Magpie became angry. Coyote only laughed at them. "You are crazy. You should know we never have berries in winter," he told them.

They went home. Magpie went off alone. At night he came back with something tied up in his blaanket. Coyote said, "What have you there?" He did not answer. He told one of the children to get water. They cooked what was in the blanket and ate. They gave Coyote none. He said, "At least you could give us some broth to drink. How did you get it anyway?"

Magpie said, "I made a hole in the ice, then another not far away. I dived into one with a fishnet and came out the other with my net full of small fish."

Coyote said, "I will try it too." He made two holes, took a net and dived. He came up with a few very small fish in the net. He wanted more and dived again. He could not find the hole to come up out of. He drowned. The next day Mole looked for him. She saw where 
he had dived. She saw the little catch he had made. Farther on she saw the other hole. "He must have dived and did not come up again," she said.

So the road ends.

The winter berries theme occurs in Shuswap, Thompson and Nootka mythology :

Coyote produces winter salmon and winterberries; Grizzly Bear Woman eats up her stores of provisions with him; Coyote makes winter again; Grizzly Woman starves (Shuswap MAM 4:631; Thompson MAM 12:312; MAFLS 6:28).

In the Nootka myth Tlehmamit's wife is able to provide an inexhaustible quantity of berries in winter for her husband's guests (IS 103).

The Bungling Host episode, the imitation of the dive for fish, has a widespread distribution, although not in connection with the winterberries episode as in the Coeur d'Alene myth.

Coyote unsuccessfully imitates Kingfisher in myths of the Sanpoil (JAFL 46:177), Thompson (MAFLS 6:41; MAFLS $11: 6$; MAM 12:206, 301), Sahaptin (MAFLS 6:165), Kutenai (BBAE 59:9), Shuswap (MAM $11: 628$ ) and Columbia River tribes (Idaho Farmer, Sept. 18, 1930).

Coyote imitates Fishhawk in Sahaptin (MAFLS $11: 165)$, Nez Percé (MAFLS $11: 183$ ) and Wasco (PAES 2:270) mythology.

Elsewhere in Sahaptin lore (MAFLS 11:167) Coyote imitates Beaver; in a Nez Percé myth (MAFLS $11: 183$ ), Otter; and in a Shuswap myth, Kingfisher, Fishhawk and Bald-headed Eagle (MAM 4:739).

A Quinault story relates that Bluejay's children are almost drowned when Bluejay has them imitate the children of Sawbill Duck, Land Otter and Kingfisher (MAM $4: 86,88,89$ ). In a Chinook myth Bluejay all but drowns his sister's children as a result of his command that they imitate Duck (BBAE $20: 179$ ).

In Coast Salish mythology Coyote imitates Fish Duck, Bluejay imitates Fish Duck, Bluejay's children imitate Fish Duck's children, Bluejay's children dive for trout for Bear (MAFLS $27: 249,344,5,349$ ).

Raven is almost fatally unsuccessful in imitating Water Ousel in a Southern Puget Sound myth (UWPA 3:39), and in a Quileute myth (CUCA 12:39, 109) Raven and his wife fail in attempting to dive like Fish Duck and his wife (CUCA 12:39, 109).

Mink has to be rescued when he imitates his wife, Eagle, or Hawk (Lower Fraser River IS 44; Comox CUCA 2:71; Kwakiutl CUCA $2: 155)$. O'mal has the same experience when he imitates Kingfisher (Newettee CUCA $2: 239$; IS 177). 
A distribution list of Kingfisher's diving may be found in ARBAE $31: 699$.

References to additional Bungling Host episodes connected with water among the Osage, Shoshoni, Zuni, Wishosk and Yana may be found in BBAE 59:294.

\section{Coyote and Badger}

Badger and Coyote families live together

Coyote kills Badger

Mrs. Badger packs up and leaves with her children

Youngest Coyote goes along carrying Coyote's favorite bucket

Coyote follows

Mrs. Badger throws back two nits which become two little girls

Coyote forgets his chase watching the girls play

Girls become stars

Badger and Coyote lived together. Coyote had five children. I don't know how many Badger had, but he had many. As Coyote was wandering aimlessly along suddenly he thought, "I am going to kill Badger because he is fat." He killed him. When Badger's wife learned of it she was sad and said, "We'll leave here."

They got everything ready, blankets and food. They put the bucket in a sack. They packed everything. Mrs. Badger told the youngest Coyote to carry the bucket. Thus she kidnapped the youngest Coyote. They had gone a long way before Coyote found it out.

"I'm going to track them." He said to Mole, his wife, "Why didn't you stop our youngest?" "How did I know it?" she asked. He said, "I am going to beat them if I ever catch up with them." He went. Far he went. As far as he could see they went ahead. He called out, "You are going to die. I am going to beat you! Turn back!"

They did not look back. He nearly caught up. He cried, "Throw down that bucket. When she said to you, 'Take it!' you knew it was the one I like best, that is the one she took from me. You are going to die."

$\mathrm{He}$ came close. The mother picked two nits from her hair. She threw them back. They became two little girls, tiny beings they were. They held each other's hands. They played and slapped each other. One licked her hands and slapped the other. Coyote laughed. "Go on, slap her back!" he urged.

$\mathrm{He}$ forgot his chase watching them and laughing at them. He laughed until his eyes became red. The children made a noise and went up to the sky where they are now stars. 
The only close parallel found was a Columbia River myth:

Coyote kills his neighbor, Badger, for food; Mrs. Badger kills his wife and three sons; she takes her children and the youngest Coyote and lights a fire; its smoke carries them to the sky; they become stars; Coyote is left alone (Idaho Farmer, Sept. 18, 1930).

Myths of other tribes are analogous in so far as the actual deed of killing a neighbor, relative or close friend is concerned, but with this any comparison abruptly ends.

\section{Calling the Deer}

Coyote lies starving

Parts of deer appear, Coyote wishes for more

Coyote discovers Woodtick and taunts her

Coyote visits Woodtick

Woodtick sets places for two, but does not invite Coyote to eat

Woodtick and Coyote live together

Woodtick calls deer

Coyote kills Woodtick

Coyote calls deer

Deer come, but run away; all the meat runs away in the form of deer

Woodtick settles in another home and has all the deer

Coyote starves at Woodtick's old home

Coyote had a house. He was starving. He lay warming his back at the fire. "I wonder what I will have to eat." For many days he had not eaten. Suddenly he smelled something. "My blanket must be burning." He felt around for what was burning. He saw half a deer foot lying there by the fire. He wondered why it was only a half, why the whole thing was not there. He chewed on it and ate it all. He lay down again. The next morning as he lay there the same thing happened, but this time a whole foot was there. "Thank you!" said Coyote. He chewed it all up, even the bones.

The next day a whole shoulder lay there. He got water and cooked it, served it and ate it all. He even drank the broth. Nothing was left. "Thank you, I've had plenty," he said.

The next morning he heard something fall. There lay the half of a deer cut from neck to tail. This time he cooked half of the piece thinking to save the next for the morrow. The next day he decided to find out where the meat came from. He pulled a corner of his blanket over his eyes. The other half of the deer fell down. He looked and saw Woodtick. She said, "Don't look at me." Coyote said, "Oh, it's you who haven't even a neck." 
She went away. Coyote used up the deer and in a few days was hungry again. Then he lay and listened for Woodtick. He got up and looked around, but there was no sign of her. He thought, "I remember where I saw her. I'll look there for her." He went off. He came to a house. There sat a woman. She looked up and put her head down again. Coyote sat down. He saw she was making sacks from grass. After a while she put her work away. She got meat, cooked it and served it. She set the table for two. Coyote sat there watching. She ate, but did not invite him. When she had finished she took up her work again. He stayed all night.

The next morning she again set the table for two but ate alone. Then Coyote got up, took meat, cooked it for himself. "You are not a real person, you don't share your food," he said and ate alone. "I set the table for two, but you didn't come and eat with me." "Did you say, "Come eat?' No, you said nothing." "Did I not take pity on you a few days ago? I fed you, but you didn't leave me alone so I left. I wanted you for my husband, but you called me names, so I left." "Well, I came here looking for you," said Coyote. "All right. You may stay."

After some days Woodtick said, "We'll have some fresh meat to eat. You go into that corner and sit still." She called, "Deer come!" Soon they heard, "xumumumu," the sound of deer running on the snow. They ran into the house. Woodtick took the tongs and pierced a hole in the ear of one, then of another. The rest ran out. She said to Coyote, "Skin it!" He butchered it and they had fresh meat to eat.

The same thing happened again. Then Coyote thought, "I'll kill her, then I'll be the one to call the deer." He took a stick and clubbed her over the head. He laid her in a corner and covered her with a blanket. After a time he thought he would like some fresh meat. He called the deer and they came in. He chose the largest. As he pulled on its ear to try to pierce it with the tongs he pierced his own ear. "Änininin, I punched myself." The deer went out, but there was meat. When Coyote went out to get water, Woodtick's spirit said in Spokan to the deer meat, "Run away, deer! Coyote has smoked eyes. Run away!" It kept repeating this in a voice which became weaker and weaker.

The dried meat hanging on a rock above the fire fell down. Coyote hung it up again. It kept falling and just as Coyote hung it up it became deer and ran out, xwan xwau, it sounded. Coyote stuffed some of the meat in his quiver, but deer burst it and ran out. Soon it was all gone because Woodtick had told the deer to run away. Only that which Coyote was cooking was left. Just when it came to a boil it turned into a deer and ran out. Then there was nothing but bones tied up in a sack. Coyote thought, "I'll cook them and make some soup. I can drink that." But as soon as it boiled the bones became deer and ran out. Then Coyote threw Woodtick out. "It's your fault the meat is all gone." 
She went away. Far off she made a house. She called the deer. Soon, $x u p^{\prime} u p^{\prime} u p^{\prime} u$, they came in. She pierced the ears of two and had plenty to eat.

Coyote sat and starved.

That is the end of the road.

Parallel myths appear in the mythology of the Sanpoil, Thompson and Nez Percé:

Coyote lies starving, wishes for food, and receives that for which he wishes; given a tent near an old wizard who brings the food, Coyote kills him; the old man revives and resuscitates all the deer-bones; Coyote transforms him into a woodtick (Sanpoil MAFLS $11: 103)$.

Coyote visits Woodtick; he strikes rock eight times, instead of four, with Woodtick's staff, and the four deer which have come run away; all the meat runs away as deer, Woodtick travelling along with it; Coyote is left starving (Thompson MAM 12:206).

In a second Thompson version Coyote asks to live with Woodtick; the fourth time he strikes more than once with her staff, gets much deer meat, and kills Woodtick; Woodtick revives, instructs the deer meat to run away with him and leaves Coyote to starve (MAM $12: 211$ ).

A third Thompson version uses the same method for calling animals: a man strikes his magic staff on the ground and deer die; Coyote becomes the man's servant and eats up his deer while he sleeps (MAM 12:312).

The food for which Coyote wishes is five times deposited at his door; the sixth time Coyote discovers Deertick and insults him; Coyote gets no more food ( Nez Percé MAFLS $11: 184$ ).

In a second version from the $\mathrm{Nez}$ Perce the calling of food element and Coyote's greed are expanded into a story of two parts with more expository detail, a myth of the Coyote-Fox cycle:

Coyote imitates his friend Fox and wishes for five bundles of food to fall; Coyote rushes out to see their benefactor who thereupon never returns; Coyote visits a man, Deertick, who allows Fox and Coyote to help themselves to his food; Coyote kills Deertick to get all his food; the venison revives, Coyote is pitched about (CUCA $25: 301$ ).

Additional Thompson, Kutenai, Shuswap and Sahaptin myths contain similar examples of Coyote's greed:

Coyote strikes the staff he has obtained from Gobbler (cp. tale 2) on the ground and obtains a dead deer; he continues to strike until smothered by deer carcasses; the deer revive; Coyote loses the staff (Thompson MAFLS 6:30; MAM 12:300). 
Coyote imitates Panther's calling of the game, but shoots it all; the animals make war upon Coyote, but cannot kill him; when hit by a small stone, Coyote turns into a plank and floats down the river $^{1}$ (Kutenai BBAE 59:169).

A starving man obtains power from the Wolves and provides the people with large quantities of game; Coyote steals the man's guardian spirits from his house; the man goes away as a wolf; all the meat in the camp runs away as deer; the people are left starving (Shuswap MAM 4:720).

By running ahead of a woman, Coyote deceives her into giving him meat four times; the fifth time she refuses and he kills her; all the meat in Coyote's caches disappears (Sahaptin MAFLS $11: 154$ ).

A man permits first Fox, then Coyote, to help themselves to meat; Coyote kills the man for not cooking the meat for him; everything runs out of the tent; Coyote is left starving and naked (Sahaptin MAFLS $11: 170$ ).

In Tlingit mythology a shaman has the power to destroy mountain sheep which his uncle calls; when the shaman dies, all the dead animals run into their skins (BBAE $39: 270$ ).

The power of calling animals is found in another story of the Kutenai which is motivated by the necessity of securing game for the starving people, since Raven has hidden the buffalo:

Jack Rabbit and Hare steal the claws for calling the buffalo which are kept by two old women; they shake them and sing; all the hoarded pemmican rolls out of the women's house BBAE 59:217).

The calling of food is included as a Bungling Host episode in various Plains and Basin myths (cp. ARBAE 31 :700).

This general story type with its many variations brings to mind an allied group of myths in which dead salmon revive and return to the sea. A typical example of the latter is drawn from the mythology of the Newettee and from Rivers Inlet:

O'meatl scolds when some of the salmon hanging in his house catch in his hair; his wife, a twin, taken from the grave, forthwith leaves accompanied by all the salmon (IS 174, 209).

Coyote suffers a similar loss of salmon for his rash words in Shuswap mythology (MAM $11: 743$ ).

${ }^{1}$ The action continues into the story of the Salmon Release (cp. tale 8). 


\section{Calling One's Kind}

\section{a. by Dorothy Nicodemus}

1. Men impound game

2. Each calls his kind

3. Coyote calls Grizzly's kind

4. Bear burns Coyote

5. Fox revives Coyote

6. Coyote calls Hail, Thunder and Whirlwind

7. Many are destroyed

Two men were making a fire corral to impound game. They burned the vegetation in a large circle leaving a small space free so the animals could run in, then they could run out. They drove many animals into the corral. One, a Grizzly said, "That's my Grizzly kind." Then an elk ran up, Elk shot it, "That's my Elk," he said. Coyote said, "That's my Coyote kind," and got a Coyote. They secured a great many animals each one taking in the kind he was himself. Thus Wolf got a wolf and so on.

At night Grizzly took his game to his house. Coyote took his coyote home. The other Coyotes liked it. The next day they hunted again. Coyote thought, "They liked my coyote so much yesterday. If I were to kill a bear I am sure they would like it much better than a coyote."

The next day he went out and called a bear. It bit Coyote and was coming toward the fire clawing and biting. The other animals got scared. The bear pushed Coyote up into the fire and he was burned. At night his partner, Fox, asked, "Didn't Coyote bite Grizzly? There was fire all over." "That's the place where he was killed," someone told him.

The next day Fox went and found the place where his friend was killed. "Where are you? You must be alive." "You must be alive," echoed Coyote.

Fox found bones all scattered about. He took the head and laid it on the ground. Then he arranged the rest of the bones and stepped over them. Coyote became alive. "Ha! I had a good long sleep," he yawned. "You weren't asleep, you were dead." "Where are all the people?"

The people came up. One cried, "That's my deer." Coyote had a desperate idea. He said, "It's my Hail, it's my Thunder, it's my Whirlwind!" "That sounds like Coyote," some person said. "I thought Bear had shot him."

It began to hail. It thundered. The people went to the prairie. Whirlwind came and blew the fire in every direction. They ran under a tree. Lightning struck it. They went into the open. Hail hit them on the head. Many were killed.

The road comes to an end. 


\section{b. by Tom Miyal}

The numbers of the abstract refer to corresponding numbers in the analysis of version a; only the incidents which differ are mentioned, the others are understood to be present.

2. Chief orders people to hunt each his own kind

3. Coyote calls Grizzly kind and cubs

4. Cubs kill Coyote

7. Coyote destroys Grizzly cubs

Once the chief of a village said, "Go hunt, Coyote hunt Coyote; Grizzly kill Grizzly ; Mouse kill his kind, Mice ; each eat your own kind."

Then in the morning they went, they hunted. Mouse cried, "Mouse, my kind!" It ran up. Grizzly called, "Grizzly, my kind!" It ran up. $\mathrm{He}$ killed it. Then Coyote called. A coyote ran up. Coyote killed it. He took it home; he and his family ate. Then Mole, Coyote's wife, said, "My! That which we ate was awful!"

The next morning Coyote said to Mole, "I am going to call, 'Grizzly, my kind!" Mole said, "Goodness no! He might bite." "No, I am going to call him." Then he called Grizzly's kind. He carried it home to Mole's house. The family ate until they became surfeited with the fat. Coyote asked Mole, "Did you like it?" "Yes, I liked it."

In the morning Coyote said he was going to call the three bear cubs who were full grown. Mole said, "No! They are fierce. They might kill you." The next day he went to hunt. Suddenly the call was heard, "Grizzly, my kind! Cubs, my kind!" Then they growled. The people said, "Now Coyote is going to get it."

There in the brush the cubs growled. Coyote screamed. He was killed. His head was bitten. The people all gathered. "Is Coyote gone?" Fox went around and asked at all the houses. He said, "Have you seen Coyote?" He was told, "Right there in the brush on the mountain we heard growling because he called Grizzly his kind."

Fox went and searched for Coyote. Near the brush he said, "My boyfriend, ${ }^{1}$ proud one, my boy-friend." Fox called Grizzly and he answered, "My friend, proud one, my friend!" Fox said, "Are you alive? I'll turn back again."

Then Fox went to where Coyote lay. Just fur was lying there. Only pieces of Coyote were lying there, even some of them had been eaten. Fox stepped over Coyote. He became alive again. Then Coyote yawning, said, "My! I must have been sleeping a long time."

\footnotetext{
${ }^{1}$ Fox and Coyote use a reciprocal term which is a mispronunciation of the usual word for "friend."
} 
"You were dead, your head was bitten by Grizzly. Look where you were lying. The place is all full of maggots." They went back. All gathered in the morning and went hunting. Coyote went also. The people said, "Look out, there's no telling what he will say. Listen when he talks. If he says something different we'll run back." Coyote called, "You, big Hailstones of our kind! You, Rain of our kind, big as pitchforks! You, Wind of our kind, blow strong! Come you, Thunder of our kind !"

The people ran home. For a long time it hailed, it rained, it thundered. Everybody was wet. Coyote went around looking. Under a tree sat the three Grizzly cubs. He killed them. He went home.

The end of the trail.

No analogues to the Coeur d'Alene Hunting One's Kind story were found in the myth bodies of the tribes studied.

Most tribes tell stories of one kind or another in the unfolding of which a dead person is revived by being stepped over. The stylistic element of Fox reviving Coyote in this manner, as it occurs in the Coeur d'Alene myth, is found in stories of the Okanagon (cp. BBAE 59:283; MAFLS $11: 72$ ) ; Pend d'Oreille (MAFLS $11: 114,115,116$, 117) ; Sahaptin (MAFLS $11: 169$ ) and Nez Percé (CUCA $25: 306,465$ ).

\section{Coyote Kills Cricket with Elk Fat (Mistaken Kindness)}

Coyote and Cricket visit

Cricket kills elk for Coyote

Coyote, feeling sorry for Cricket, feeds him meat

Coyote revives Cricket

As Coyote was going along he heard a noise which frightened him, t'a t'a t'a. He looked for it and found it was a cricket. He said, "Hello, my younger brother! It's a long time since I saw you." They shook hands. Both were glad. Coyote said, "Do you know we are real brothers? My father and his father, then his father and his father were related. So you are my little brother. Where is your house?" Cricket answered, "I have no house." "But what do you do at night?" "I just go to sleep in the grass." Then said Coyote, "Oh! You must take the trail to my house."

Then both went. Coyote returned home and just as he started to build his fire Cricket arrived. "Come in! Sit down," said Coyote. Both were glad and talked. After a while Coyote said, "I am poor (humble). I 
have nothing to eat."' "I am not hungry," said Cricket. Coyote said, "But I am hungry."

He did nothing but walk around looking for food. They went to bed and slept. The next day Coyote went out again to look for food. Cricket went out and ate grass. Then he slept. Every time he was hungry he just went out and found plenty of grass. Toward night Coyote came back with two mice. Cricket said, "I saw something good for you." The next day he said the same thing. Coyote thought, "You go and eat grass."

The grass was dry and Cricket did not like it. Coyote went far that day. Cricket found good grass and ate his fill. Then he lay down, but soon he heard a noise like a horse walking. He thought it might tread on him. He went in another direction and still heard it. He saw it was an elk. He made his noise $t^{\prime} a t^{\prime} a t^{\prime} a$. It frightened the elk. He looked around. Then Cricket went t'a t'a t'a. He ran off, fell over a cliff and was killed. Cricket was glad. He thought, 'Now Coyote can eat. $\mathrm{He}$ is starving. He can have plenty."

Cricket went under the cliff. There lay the elk. He had large antlers. Cricket climbed up on the largest branch and sang, "Tuts tuts tuts, I killed him."

When Coyote came home he wondered where Cricket was. He slept in the morning. He thought, "I wonder where he is. Maybe he is dead."

Thinking he was dead Coyote pulled Cricket's little bag of belongings apart, took out the sinew which was the only thing of value, toasted it and ate it. Then he cried for Cricket. He took the sack and burned it.

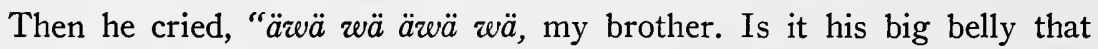
ought to be mourned; $\ddot{a} w \ddot{a} w \ddot{a}$, is it the back of his neck which is pitiable? Is it because he spits?"

(This song is repeated four times.)

"Why is his thigh long?" He heard someone shout, "Tuts tuts tuts." "Ha! he isn't dead. He is still alive." Then Coyote sang the mourning song again and Cricket answered with his hunting song louder and louder. Then Coyote said, "What is the matter? So you are still alive?" Cricket said, "Come and cut up the meat or it might spoil." Coyote said, "Oh my! Thank you, so you killed something."

When he had cut half of the elk he roasted it and offered it to Cricket. "No, I don't eat it. Fix it for yourself." Coyote cooked it and while he was eating Cricket ate grass. His stomach swelled. He lay down to sleep. His mouth was open.

Suddenly Coyote looked at him and said, "Poor thing, my young brother. Here am I eating all the meat I want and his mouth is all

\footnotetext{
${ }^{1}$ Formal way of inviting guests to eat but, as is usual with Coyote, the phrase was only too true !
} 
chapped from eating grass." He dipped fat off the meat with a spoon and put it on Cricket's mouth usuts suts suts! He burst open. His stomach was all spread out flat. Coyote cried, "I didn't mean to do it, my young brother."

He took elk sinew and sewed him the entire length of his body. $\mathrm{He}$ smoothed down the sewing. He stepped over him. He became alive. "I told you I never eat meat, only grass." Coyote was happy again. He said, "I pitied you because your mouth was so dry. I thought I ought to grease it."

Then Coyote went away. Cricket went away.

Allied myths, as far as the Cricket-Elk incident is concerned, are to be found among the Sanpoil and the Thompson:

In the Sanpoil myth Cricket kills a buffalo bull; he and his brother, Grasshopper, feast upon it till Coyote carries them away; Cricket's grandmother pursues Coyote in the form of a rock (MAFLS 11:103).

In the Thompson version Mountain Grasshopper, kills Elk, upon whom he and his brother, Common Grasshopper, feast (MAM 12:331).

The outstanding characteristic of the Coeur d'Alene myth, Coyote's unusual kindness which makes for evil, was not found duplicated.

\section{Coyote and Nighthawk Change Coats. (Rolling Rock)}

Coyote pursued by rolling rock

Nighthawk carries Coyote to safety and splits rock

Coyote secretly exchanges shirts with Nighthawk

Nighthawk recovers shirt from Coyote; rock flattens his head

In the morning Coyote went off. All day he walked. All at once he saw a rock on the ground. He sat down and started talking. "This rock is good. I wish it was at my house. I would sit on it all the time because it is so nice and smooth." He defecated on the rock. He went away. $\mathrm{He}$ went far during the day. Every time he looked back he saw dust on his trail. It frightened him so he went in zigzags because he thought the rock was trailing him. He went in a circle; always the dust was there. He thought, "They are chasing me." He ran faster, then down to the water. He jumped in. The rock fell in and just missed his tail.

Coyote swam across the river which was very wide. When he came out of the water he walked a little to get warm. He spread his wet blanket and lay down because he was cold. Just as he was going to sleep he heard 
something like a person coming out of the water. It was the rock. Coyote grabbed his blanket and ran. The rock touched his blanket and tore a piece out of it. He ran further and saw a nighthawk flying around. "Come down and help me out, partner," he begged. Nighthawk came down. He said, "Hold on to my belt." Coyote said, "It's too little, it will break. Let's double it with mine."

"No, it won't break."

They flew up, Coyote holding on to Nighthawk's belt. The rock called to Nighthawk, "Put him down here. I want to kill him because he defecated in my eye."

Coyote said, "No, don't take me down!" Whenever Nighthawk flew down Coyote begged him not to alight. Finally he flew suddenly down on the rock and it split into pieces. Coyote was glad. Nighthawk said to him, "Come, take some for earrings." Then he said, "Come, let me carry you again," but Coyote said, "No, my chest might get sore, but because I am grateful I will carry you." He carried him around. Nighthawk went to sleep. Coyote went slowly, then put him down. He looked at him and coveted Nighthawk's shirt. He took off Nighthawk's shirt and his own. He put his on Nighthawk and Nighthawk's on himself. He thought he looked nice and said to himself, "Now when I go to Spokane how nice I will look!"

He went away. He had not gone far when he found himself walking in jerks as Nighthawk flies. Every once in a while he jerked upward, each time higher, but each time swooping to the ground again. Finally he went very high, bumped into a tree and was killed.

When Nighthawk woke he felt chilly. He said, "Where is my shirt? It is gone." Coyote's shirt was on him. "That Coyote is crazy, I suppose he's got my shirt all bloody by this time," he remarked as he took Coyote's shirt and trailed him. A little way off he found tracks, they were lost and found again after a short distance. Finally he found Coyote lying dead. He took his shirt off Coyote and put it on. Then he went to sleep. When he woke up his head was heavy because a rock was on it. It had made his head flat. His mouth was stretched out wide and pinched together on each side.

Myths which somewhat resemble the Coeur d'Alene story are to be found in Wasco and Shuswap mythology. In the Wasco myth the pursuing rock gets stuck in mud and Coyote escapes unassisted (PAES $2: 272$ ). In the two Shuswap versions, which belong in the series of Coyote-Fox episodes, one occurring among the North Thompson Shuswap, Coyote obtains for himself Fox's golden eagle feather (silver fox skin) robe which Fox recovers in turn with the aid of a whirlwind. The 
rolling rock element is lacking as well as the Nighthawk character (MAM $4: 634,742$ ).

A Sanpoil myth (MAFLS 11:103), which in its essential features correlates with the Coeur d'Alene story "Coyote kills Cricket with Elk Fat," concludes with the Rolling Rock episode: Cricket's grandmother turns into a rolling stone and pursues Coyote who escapes by resorting to his magic power (MAFLS $11: 103$ ).

Reference to the Rolling Rock episode as a variant of the Rolling Skull myth may be found in PAES 2:272, footnote 2 .

\section{Cricket Rides Coyote}

Coyote coaxes Cricket to ride him

Cricket tickles Coyote

Coyote bucks, Cricket's legs fall off

Coyote was walking. Suddenly he heard "tsututut!" He jumped. $\mathrm{He}$ saw a Cricket, "Ha, my younger brother," he said, "Do you know we are brothers?" "No, I didn't know it." "Yes, I am your brother. Where is your house?" "I have none." "All right, let's go together." "No, you go too fast for me. I am very slow." "Well," said Coyote "Ride me." "You're too tall, I can't mount you." "Come," said Coyote. "We'll look for a rock. I'll stand by it. You can climb up on it and mount me."

They found a rock. As Cricket was mounting Coyote said, "My! I am ticklish. I might buck. I haven't been ridden for a long time. Hold fast!" They started off. Somehow Cricket switched Coyote. Off he went. He started to buck. Cricket fell off. He said, "That's enough! You go on." But Coyote insisted, "No, come on. Ride me again. Put your legs under my arms and I'll squeeze you tight." Cricket mounted again. "Now hold tight, because you know how ticklish I am."

Cricket rode Coyote. Soon he bucked because he was being squeezed. Cricket's hip came off. Coyote bucked and the other hip fell off. Coyote looked back. There lay Cricket without his legs. Coyote said, "I guess I better go on." He went off.

That is the end of my road.

No parallels were found to the Coeur d'Alene Coyote-Cricket myth.

Among the Kutenai Coyote incidentally gives Locust a ride. The ride is interrupted however by a meeting with Grizzly Bear, whereupon Coyote sets Locust down at the edge of a cliff; Locust scares Grizzly into falling off the cliff; Grizzly dies (BBAE 59:2). The Kutenai myth fits more aptly into the category of those myths dealing with the power of the small one. 


\section{Coyote Snares the Wind}

Wind blows constantly

Coyote catches Wind in trap

Coyote releases Wind on his promise not to blow all the time

At one time the wind blew hard every day. Then Coyote thought, "I'll snare the wind. It passes around the mountain so that is where I'll have to go. I'll go through the mountain."

There was a small hill between two larger ones. ${ }^{1}$ That is where Coyote set the snare. He went home and slept. The next day he went to look. Something was caught in the snare. It had long curly hair, a wide mouth and big eyes. Coyote stood with his arrow ready and said, "You are going to die." Just as he was ready to shoot Wind spoke, "Don't I look pitiable. Don't shoot me!" "You are absolutely no good! Every day you blow around the houses and mess everything up. You're going to die. Get ready!" "Please have pity on me."

"If you promise me saying, 'I won't blow any more,' you can live." "I don't travel around for nothing." "What are you always looking for ?" "What will become of me if I stay home? What will I eat?" "What do you eat now?"

"I really don't know."” "All right! If you say, 'Four days I will blow. Then I'll stop,' then I'll let you live." "All right! I promise."

Coyote pulled the string and took it off the neck of the wind. So he lives today, but he blows only sometimes, not all the time.

That is the end of the road.

The capture of the wind and his release upon promising not to blow steadily is a myth theme of wide distribution. Although there is a marked similarity in the elements of the various versions, the myth in the territory covered here is seldom found as a part of the Coyote cycle outside the limits of Coeur d'Alene mythology. A Sanpoil myth in which Coyote takes the measure of Blizzard, is an exception.

Coyote, aided by Fox, throws Blizzard in wrestling; Coyote decrees blizzards shall not last more than two to three days and people shall no longer freeze to death (JAFL 46:163).

A party sets out to make war on Southeast Wind; Southeast Wind slips helplessly over the backs of halibut into the war party's canoe; Southeast Wind is released upon promising to provide more pleasant weather: this is the general outline for the version found in myths of

${ }^{1}$ Some say it was at Tekoa Mountain, others that it was at Liberty Mountain.

Perhaps the informant did not know. 
the Haida of Skidegate-Raven is the leader of the party of birds and Halibut People (BBAE 29:129; MAM 8:183). Among the Haida of Masset and the Kwakiutl Chief of the Ancients leads the party; Golden Eye, Wren, makes a fire in Southeast Wind's stomach to drive him outside; Southeast Wind promises four days' good weather at a time (some summer and some winter) (MAM 12:98, 350; CUCA 2:227). Among the Nervettee-Kute'na decides to get good weather (IS 186); and in Tsimshian myth-Txämsem leads the fish against South Wind; Red Cod causes Master of the South Wind to cough; Devilfish sucks him out of his house; South Wind promises four days of good weather at a time (ARBAE $31: 79$ ).

Additional myths concerned with the trapping of the wind are found among the Thompson, Shuswap, Chilcotin, Southern Puget Sound people, Nootka, Haida and Upper Chehalis.

The youngest contestant snares the Wind in his noose; he releases him on his promise not to blow so hard (Thompson MAFLS 6:87; MAM 12:330; Shuswap MAM 4:702).

Cold winds blow constantly; Fox and Hare release the warm Chinook wind of the Heat people to act as a check upon the Cold People's winds (Shuszvap MAM $11: 624)$.

The Chief's son snares the Wind, a boy with a pot-belly and streaming hair; he releases him on his promise not to blow so hard and frequently (Chilcotin MAM $4: 42)$.

The people seize the blustery South (Chinook) Wind; they stand him up; he blows only a few days at a time (Southern Puget Sound UWPA $3: 69$ ).

The people send Winter Robin to kill the Winds; Winter Robin sits by the Winds' fire and forgets to return to his people; Gull leads the people to Winds' house; the people conquer all but West Wind; West Wind promises to allow the tides to change twice a day (Nootka IS 100).

Southeast gives the people bad weather; Master Carpenter catches Southeast; Southeast gets back to his home in the sea; the people stop irritating him by their use of his sister's name as a word (Haida MAM 8:190).

Northeast Wind, dwelling in the sky, freezes the people; Southwest Wind leads his people against him from their ocean home; Snowbird pulls the sky down for their ascent; Southwest Wind's side is victorious; on his return from the sky Snake murders his sister Toad for mocking his cross-eyes. In a second battle Southwest Wind kills five of the seven Northeast Wind brothers by using a watersprinkler; the southwest wind now melts snow and frost (Upper Chehalis MAFLS $27: 75)$. 


\section{MYTHS NOT IN COYOTE CYCLE}

\section{Catbird}

Catbird, a little boy, lives with his grandmother

Catbird wishes for arrow

Catbird rides Elk and destroys him

Catbird sings for help to skin Elk

Wolf discovers Catbird's kill

Wolf provides moccasins for Catbird

Catbird destroys moccasins

Wolf goes for help

Catbird and grandmother set decoy of rotten wood

Catbird and grandmother smoke elk meat

Five Wolves fooled by rotten wood

Wolves follow Catbird and his grandmother

Catbird kills Wolves with hot rocks covered with fat

Catbird prepares elk sinew for bow and wishes for boxwood; gets it

Catbird wishes for someone to feather his arrow

Catbird lives with Eagles and secures feathers

Grizzly feathers Catbird's arrow

Catbird goes to water and fishes up as he wishes-fishing tackle, bucket and fish

Catbird eats all his fish alone

Grandmother leaves him

Catbird fishes more wishes-blanket, knife, dish, woman and child

Catbird's grandfather warns him against his good luck

Catbird and family visit girl's people under water

Child eaten by Water Monsters; Catbird and his grandfather return to earth

Catbird was a little boy who lived with his grandmother. One day he said, "I ought to have something to shoot with." "Impossible!" said his grandmother. "I have no materials to make it." "I'll go look for something," he said.

$\mathrm{He}$ went. He came to a river. He called to an elk, "Give me a ride, my father's sister, my father's sister, ayäyu ..." The elk answered, "No, my flesh is too old and tough, my fat is coarse."

Another elk came by, one of the old elk's children. Catbird cried to him, "Give me a ride, my father's sister, my father's sister, ayäyu ..." "No, I'm too young, my fat is too tender."

Then the largest oldest elk was requested to ferry Catbird across. "You are pitiable, go right in and sit in the hair of my heel." As he went into the water Catbird cried, "älilili, my little moccasins are getting wet." "You are pitiful, crawl up to my knee where the hair is longer." Catbird crawled up, then complained, "älilili, my little moccasins are getting wet." "Come up to the tip of my tail," said Elk.

Catbird went up where the hair was long, but still complained. Then 
he moved up to the shoulder and then into Elk's ear, but even there he feared getting wet. "What can we do so you don't get wet?" asked Elk. "Try sitting in the hair of my nose." Catbird went into Elk's nose and did not stop there, but rushed right through his nose and throat to his heart. He sat there, "My! It's warm!" he thought. Elk thought, "That rascal of a Catbird! So that was what he went into my nose for."

Catbird took off his little moccasins and hung them up by Elk's heart. Then he did something to the heart and Elk died. Catbird ran out but he forgot his moccasins. Elk lay on the ground. Catbird sat up high and sang.

"What might I use to sharpen my knife?

What might I use to drop on the whetstone?

tsa $\cdots$ tsar tsar tsar tsar."

A wolf was walking by. He heard Catbird and understood instantly. "He must need a knife," he thought. When Catbird saw Wolf he pretended not to see him, he looked past him and thought, "I suppose he'll take it away from me, my game which lies there." Then he sang:

How am I going to shave my little arrow ${ }^{1}$

What may I drop on it to smooth it?

tsa $\cdots$ tsar tsar tsar tsar."

Wolf understood him and asked, "Did you get game?" "No, I made no kill." "But you were just singing:

\footnotetext{
"How may I sharpen my knife?

"What may I drop on my sharpener?"
}

"No! I said,

'How shall I shave it

"How shall I smooth it?"

They kept arguing in this way until finally Catbird said, "Yes, I got some game." "Where is it?" "It is lying there." Wolf said, "I have a knife. I'll skin it. Go get your mother's brothers so they can come and lick the blood." Catbird said, "I have no moccasins." "Go on, I'll lend you some." "No they're too big." "I'll fix them for you. I can tie them so they are smaller."

${ }^{1}$ A slight change of the word here changes the meaning from skinning an elk to shaving an arrow. It is impossible to render this satisfactorily in English. 
Wolf put the moccasins on Catbird and tied them tight. He went out of sight, but only to beat them with a rock until they were in shreds. Then he came back and said to Wolf, "They're all worn out."

"What is the matter? They're very thick. How did they get all ruined like that? Soon I'll have this elk skinned, then I'll go get your uncles so they will lick your (really your elk's) blood."

Wolf ran off and Catbird finished skinning the elk and covered it. Then he ran home to his grandmother. "I got some game but the Wolves will take it away from me." "Hurry, take your basket. We'll take it far so they cannot get it."

He took his little basket and they ran to where the fresh meat was lying. They put it all in Catbird's basket. They gathered rotten wood, laid it just where the meat had been, and covered it with the elkskin. Catbird took off his little shirt and his little hat and hung them on a bush so that it looked just as if he were sitting there himself. They went, far they went. They took the meat to a cliff. Near the edge they smoked the meat. Catbird put five cooking stones into the fire and laid the layer of fat from around the elk's stomach near him.

When Wolf went he told his four children, "Catbird got an elk. We'll get it from him. We'll run. When you are biting Catbird I'll say to you, 'Don't, you'll scare him,' but don't listen to me."

The children ran. Wolf said loudly, "Look out, you'll scare your little nephew." The first ran up to the rotten wood and bit it. They sniffed and walked around it. Old Wolf thought, "I wonder why they do not eat it." He came up and the children asked, "Where is the meat?" "There under that skin." He uncovered it. Nothing was there. Then the oldest Wolf said threateningly, "There's no place on earth I do not know."

They looked for tracks and followed them until they saw smoke. The children ran and saw Catbird. Catbird took a stone from the fire and wrapped the "veil" of fat around it. As the first wolf came under the edge of the cliff he looked up. Catbird threw down the hot rock with the grease coating and said, "Open your mouth. This will be your first tidbit."

Wide he opened his mouth. Catbird threw the stone in. Immediately he had heartburn. "Your brother, why just one bite gives him heartburn!" Then he killed all of the wolves with his five grease-coated rocks.

After Catbird had helped his grandmother smoke the elk meat he prepared sinew for his bow. "I wish I had a bow," he whined. "I wish I could be where the bowwood tree cracks in the wind."

"Impossible!" said his grandmother. "You would probably get caught in the crack yourself." "I'm going to get it anyhow."

${ }^{1}$ The heart of the yew was used to make the bow (cp. ARBAE 45:95). 
He went for it. He brought it home and as he sat down to shave it he said, "I wish I had someone to feather my arrow, one who is an expert. I wish Grizzly would do it for me. I think he would do it well." "Impossible!" said his grandmother, "he would bite your head." "You are always saying 'Impossible!' Tomorrow I am going to find out where he is." "Right at the edge of the wood in a hole he lives," volunteered the grandmother.

The next morning Catbird went toward the timber and, as he approached, he saw Grizzly eating. He said, "Never mind. I won't shoot you. I came to ask you to feather my bow." "All right," and he went back with Catbird.

As they came near the house Catbird said, "Wait here, let me go in." He went in and said to his grandmother, "Why don't you have a fire?" She went out for wood and saw Grizzly standing by the door. She ran in and said to Catbird, "Why do you do such outrageous things?" "Well," said Catbird innocently. "He'll be a great help. He is going to feather my arrow."

In the morning Catbird got the wood for the arrows. As the arrows were being made he said, "I wish I had some eagle feathers." "Impossible!" exclaimed his grandmother. "What would you do with them if you had them?" "I'll go get some."

He searched long and finally found an eagle's nest with Eagle's children in it. The mother Eagle was away looking for something for them to eat. She caught Catbird and carried him to the nest and laid him in it alive. When the little eagles ate he ate too. I don't know how long he stayed there, but until the feathers of the little eagles had grown to just the right size for his purpose. Then he tied two of the eagles together and prodded them until they flew out of the nest; he sat among their feathers. They were not able to fly far but flopped to the ground. He then pulled out some wing and tail feathers and went home. He laid the feathers down in front of Grizzly who finished feathering Catbird's arrow. Then Catbird sent him away.

One day Catbird was wandering about and suddenly came to the shore (of a lake?). He sweated for many days. Then he saw a fish in the water. "I wish I had a line and hook." Some way he got the fishing tackle. He fished and got a bite. "I wish I had a bucket," he went on. He had another bite, pulled in the line and found he had fished up a bucket. $\mathrm{He}$ cooked the fish but did not share it with his grandmother. When he went home his grandmother gave him some food but he did not eat. Again he sweated. Again he fished. Again he got a bite and cooked and ate the fish all by himself. When his grandmother offered him food he said, "No, I am not hungry." 
When he had gone off somewhere the grandmother went to the shore to investigate. She found his bucket. There were pieces of fish sticking in it and on the bottom was a small fish eye. She was sorry Catbird was so stingy.

The next morning when he went to sweat she called to him, "I'm leaving you. You didn't share a shred of your fish with me." He looked up and saw his grandmother going up into the air with something on her back. "Don't leave me. Come back to me." "No. I'm leaving you for good. You didn't share a bit with me."

In vain he implored her. For a long time he cried. He went to his house. He had no blanket, everything was gone. He went to the shore and sweated. Then he fished and everything he wished for appeared on the hook. He fished up a blanket. Then he ran to his mother's father and said, "I can fish up anything I choose to mention, just like that! All I need to do is to fish and wish."

"You think that is good luck? You'll find it is the other way around." Catbird however was excited and went back and fished up a knife, a dish and other things. Then, "I wish I had a mate," he said. At that he felt his line being pulled. He pulled hard and fished out a person. $\mathrm{He}$ ran to his mother's father. "I fished out a person." "You better listen to me. That is all for no good."

Catbird went back and saw a girl sitting there. Then he said, "I wish I had a child." He threw in his hook and this time fished up a child. $\mathrm{He}$ ran to his grandfather and said, "This time I fished up a child." Again his grandfather warned him, "You better watch out. You'll go too far and then you'll die."

He went back to the shore and the girl said to him, "Let's go back to my parents." Once more he ran to his grandfather. "She tells me, "Come back to my people." "I've already warned you often. You are going to die, but I will go with you, then at least you will not be alone."

They all got into a canoe, Catbird, the girl with the baby and the grandfather. The whole canoe with its load dived to the bottom of the water. They saw a house on the shore, but the shore itself was all covered with ice. The grandfather went up it all right. He did not even slip. When he came up to the door he recognized the girl's parents. "Whatever you do to us we'll do to you," he said.

Then Catbird and the girl with the baby came up and they all went in. The house was made of ice and frost. When the child was taken from its mother it disappeared. After they had stayed two days Catbird's grandfather said, "Let us go back." "I am not going back again," said the girl. "Neither am I," said Catbird. "No, let's go back together. They 
have already eaten your child. They will eat you too. They are maneating monsters."

So just Catbird and his grandfather went back to the canoe and it came up to the surface of the water again. (There is much more to this story but Dorothy did not know it. When he came to the surface Catbird became some other kind of a boy and went about in his customary unruly way trying to get everything he wanted. Coyote stole his bow and arrow and Fox also enters into the tale.)

The power of the little one is a common myth feature. Small or young characters with exceptionally great power have roles in at least one myth of practically every tribe in the territory covered by this analysis. Among these myths moreover there are a number which correspond closely to the Coeur d'Alene outline of the Catbird story, through the point at which Catbird is deserted by his grandmother.

Among the Sampoil, Thompson and Kutenai one finds the identical setup of the little boy living with his grandmother, who wishes for a bow and arrow and lets nothing deter him till he gets it.

The people are unable to hit the sky with their arrows to start an arrow chain; Woodpecker proceeds to obtain arrows; he lights on Elk's neck while Elk is crossing the river, cuts it, and kills him; he makes a bow out of Elk's rib; he fashions arrows out of serviceberry wood; he precipitates one fight between Eagle and Bald Eagle in order to collect their feathers for his arrows, another between Flint Rock and Hard Rock to procure chips for arrowpoints; he shoots the arrow chain and the people ascend to the sky to obtain fire (Sanpoil JAFL 46:152).

Woodpecker comes upon a dead elk and sings for a knife; Wolf discovers Woodpecker's game; Woodpecker fails five time to fetch Wolf's nephews, while Wolf is skinning the elk; Wolf goes for them; Woodpecker fetches his grandmother and the two carry the elk to a cave; the Wolves find them; Woodpecker kills the Wolves with hot rocks covered with fat; he makes arrows; he takes a deer rib for a bow; he wraps snakeskins around his arrows and trades some of them to Coyote; the snakes bite Coyote to death; Fox revives Coyote; Woodpecker shoots an arrow chain on which the people ascend to the sky to obtain fire (Sanpoil JAFL 46:153).

An old woman and her grandson live together; the boy rides Deer across the river and cuts his throat; the five Wolves discover the kill; the old woman sets a decoy of rotten wood and wishes herself, her grandson and the meat onto the ledge of a cliff; the Wolves are fooled by the rotten wood; the boy kills all but the youngest Wolf with hot stones wrapped in suet; the boy precipitates a fight between two eagles and gathers their feathers for new arrows; he turns into a chickadee (Sanpoil MAFLS 11:107).

When the three Sanpoil versions are used to supplement one another, the combination is seen to reproduce the Catbird's story incident for 
incident through three-quarters of the myth, that is, as long as the little fellow and his grandmother live together. The last fourth of the Coeur d'Alene myth, Catbird's fishing of his wishes out of the sea, is replaced by the shooting of the arrow chain and the Earth People's quest for fire. The Sanpoil reference to Woodpecker's exchange of arrows with Coyote may be a slight clue to the unrecorded continuation of the Coeur d'Alene story, which the narrator had forgotten beyond such vague ideas as Coyote's theft of Catbird's bow and arrow, etc.

A boy is advised by his grandmother on the making of a bow and arrows; he fights with Eagle and pulls out his tail-feathers; he rides Buck Deer, cuts his neck and takes sinew for his bowstring; he precipitates a fight between the two owners of arrowstone and gathers up the stone which drops off them; Raven chips the stone into arrowheads for him (Thompson MAFLS 6:75).

Wren wishes for a bow and arrow so he can reach the sky; he rides Elk across the river and stabs him; Wolf tries to steal the elk; Wren kills Wolf with hot stones wrapped in fat; he uses Elk's rib for a bow, obtains feathers for his arrow by having an eagle carry him to its nest and gets flint by means of a fight between its owners; he proceeds to where people are assembled to shoot an arrow chain (Kutenai BBAE $59: 283,21$ ).

Despite his great-grandmother Frog's warning, Yaukwe'ikam steals serviceberry bushes from Grizzly Bear to obtain arrowwood for arrows; he receives feathers in exchange for ear ornaments from the ducks on the lake; he kills Bull Moose for Mouse and takes the moose's sinew; he destroys two large squirrels blocking the trail, opens it up and procures bowwood, thus completing his bow and arrows (Kutenai).

A third Kutenai variant of the Coeur d'Alene Catbird quest for bow and arrow is a Chickadee and Elk story, one of the most faithful parallels of Catbird's experience with the Elk and the Wolves.

Chickadee wishes to get some elk meat; he rides Fat Elk across the river and stabs him; he sings for help to skin Elk; Wolf discovers Chickadee's kill and commences to skin it; he provides Chickadee with two pairs of moccasins, both of which Chickadee destroys; Wolf sets out to fetch his family himself; Chickadee entices him back twice to tire him; Wolf takes Elk's tongue home to his father-inlaw who eats it so quickly he chokes to death; Chickadee sets a decoy of rotten wood and fetches his grandmother Frog; Frog transfers her grandson, the meat and herself onto a high rock; Wolf and his children return for the game and are fooled by the rotten wood; Wolf drinks at the river and is duped by Chickadee's reflection in the water; Chickadee kills Wolf with a hot rock covered with fat; he declares the Wolf children shall henceforth be wolves (Dyer ms.).

The Shuswap, Nez Percé and Chilcotin likewise relate the story of the little one-corresponding to Catbird without a grandmother-who makes 
a big kill and foils Wolf's, Coyote's or Wolverine's attempt to take it away from him.

Wren rides Bull Elk and scratches him to death under pretense of looking for his woodticks; Wolf hears Wren singing about his kill; Wolf swallows Wren four times; each time Wren escapes out of Wolf's anus; Wren admits his kill to Wolf; Wolf cuts up the elk and instructs Wren to carry the pieces to the young Wolves; Wren takes them instead to a ledge and invites the birds to eat with him; he kills Wolf and her children with boiling hot meat which burns their insides (Shuswap MAM 4:751; ARBAE $31: 940$ ).

Porcupine, sitting under Buffalo's foreleg, rides across the river and slashes Buffalo to death; Coyote hears Porcupine singing for help in sharpening his knife; Coyote challenges Porcupine to jump over the buffalo, the winner to receive the meat; Coyote wins, wounds Porcupine and leaves his one child behind while he fetches the rest of his family; Porcupine recovers, kills Coyote's child, sets him up as a decoy and takes the buffalo meat to the top of a tree; he drops the buffalo head down upon Coyote and his family and kills them (Nez Percé JAFL $21: 21$ ).

Porcupine rides across the river on Caribou and pierces him with a quill; Wolverine comes up and helps Porcupine skin the caribou; Porcupine eats the fat off the intestines he was sent to wash; when Wolverine strikes him, he feigns death; Wolverine goes to fetch his family; Porcupine takes the meat up a greased tree; he drops a sharpened rib down upon the Wolverines; Wolverine jumps aside and escapes; Porcupine helps him up the tree and tells him to defecate on a small branch; Wolverine is plunged to his death (Chilcotin MAM 4:40).

A Thompson version of the episode takes an unusual twist at the end -the young one is vanquished:

Wren calls Elk and jumps into the fattest elk's anus; he cuts its heart and jumps out, forgetting his knife inside; Wolf and Coyote hear him singing for help to butcher the elk; they carve it up for themselves leaving only the paunch for Wren (MAM 12:342; ARBAE $31: 944$ ).

In a $T$ simshian variant the little boy is temporarily overpowered and deprived of his meat but, with supernatural aid he takes his revenge:

Tsak lives with his grandmother; Grizzly Bear steals their salmon; Tsak scolds Grizzly; Grizzly snuffs him in; Tsak makes a fire inside Grizzly and kills him; Tsak fetches his grandmother and they cut the bear up; the boy visits the village of the Wolves; the Wolves tie him up, go to his home and eat all the bear meat; a supernatural being helps Tsak; he marries Wolf chief's daughter and receives much property (BBAE $27: 117$ ).

The small one's experience with a bear is the subject of a Bella Coola myth:

The bird, Stska'aka, discovers Bear is stealing his salmon; he scolds Bear; Bear snuffs him in; Stska'aka comes out through Bear's anus; the fourth time Bear 
corks himself up; Stska'aka makes a fire inside Bear and kills him; Stska'aka flies to his mother; she makes the stone on which they sit grow into a cliff; the two roll redhot stones down upon Bear's four friends who come to avenge him (IS 256).

In a story from Rivers Inlet when his older brothers fail to catch game, Stskin goes forth and burns a bear to death in the manner of Stska'aka among the Bella Coola; Stskin is obliged to cut off the bear's nose and bring it to his mother to convince her of his kill; the men go to fetch the bear; Raven gets all the fat and meat by trickery (IS 212).

In Chinook, Coast Salish and Nez Percé myths the small one's problem after he has destroyed the elk or bear is with his grandmother rather than with a thieving Wolf or Coyote.

Entsx calls a male elk, enters its anus, cuts its stomach and kills it; he fetches his grandmother to help him pack and prepare the elk; when the meat is boiled, his grandmother makes holes in all his spoons; he pours the boiling water over his grandmother and kills her (Chinook BBAE 20:119).

Wren calls Elk, enters him, cuts his heart and kills him; he butchers him and fetches his grandmother to help pack the meat; his grandmother insists on packing the genitals and copulates with them. Wren misses the elk marrow which he had saved; he strikes his grandmother on the throat and the marrow comes out; she leaves him, weeping; the people dress Wren's grandmother up and give her to him for a wife (Upper Chehalis MAFLS 27:33). Wren frets until his grandmother has intercourse with him; a bird detects them; Wren fights the bird; his grandmother burns him up by mistake; the bird escapes; Wren turns into the wren, his grandmother into the bluebird (Upper Chehalis MAFLS $27: 36$; Cowlitz MAFLS $27: 185$ ). Coon insults Grizzly Bear; Grizzly swallows him; the agates on Coon's back cut Grizzly to pieces; Coon fetches his grandmother; she cohabits with Grizzly's genitals in the sweathouse; Coon burns her up; he eats all the bear meat and crawfish; still hungry, he eats his grandmother's private parts by mistake; his teeth fall out (Cowlitz MAFLS $27: 220$ ).

Raccoon Boy encounters a bear; he kills her by thrusting her thorn needle into her ear; he fetches his grandmother; he sends her to the menstruation lodge and eats up all the bear meat; his grandmother wraps herself in a bearskin; she crushes him to death (Nez Percé CUCA $25: 265$; MAFLS $11: 197$ ).

A Quinault myth concerns itself exclusively with the little one's experience with Elk.

Elk has been taking away Wren's spears; Wren flies into Elk's nose and scratches him; Elk bleeds and sneezes to death (MAM 4:126; ARBAE 31 :944).

Catbird's method of killing the Wolves with hot rocks covered with fat and his contact with the Eagles to obtain feathers are two incidents 
in the stories of the small one who makes a bow and arrow which have a far-reaching stylistic significance.

The hot rock episode is used in a wide variety of myths which may have no further points in common. A list of references to representative instances where the device is resorted to follows: Quinault-Wildcat boy against a pursuing monster woman (MAM 4:116: ARBAE 31:940). Haida, Tlingit and Tsimshian-Raven against male or female Grizzly Bear, upon whom he wishes to feast (MAM 14:312; BBAE 39:7; BBAE 27:57). Tlingit-trickster Raven against his sister, the guillemot (IS 317). T simshian-Txämsem against two Grizzly Bear wives, whose meat replenishes his larder (ARBAE $31: 88$ ) ; Nez Percé, Kathlamet and Wishram-Coyote against Grizzly Bear (CUCA $25: 183$; BBAE 26:149; PAES 2:165). Krakiutl and Nervettee (CUCA 2:241; IS 177)Squirrel-made-to-go-up against Omal who peeps at Squirrel through a knothole (CUCA 2:241; IS 177). Kutenai-Woodpeckers against Nalmu'qtse; the red-hot stone wrapped in a mountaingoat's heart misses its mark (BBAE 59:77, 87). In a Thompson myth the fugitive Black Bear children from their point of vantage in a tree promise to throw the youngest Black Bear to Grizzly Woman agitating below; they throw her dry rotten wood mixed with ants; Grizzly is choked and blinded (MAM $12: 220$; MAFLS 6:71).

The tussle with the Eagles for eagle feathers has a special place in myths of the Transformer cycle. The transformer is assaulted by maneating Eagles while attempting to gather feathers for arrows or decoration and his dealings with the birds get under way.

In a Chilcotin version Lendixtcux wears the birds out from flying with a stone tied to their feet and kills them; he spares one eaglet instructing it never to kill men again (MAM 4:12).

Among the Shuswap Tle'esa deludes the Cannibal Eagle into believing him dead by dripping red and white paint from his mouth; he kills Eagle and takes [his brothers take] his tail-feathers; he commandeers the eaglets to carry him down to earth and transforms them into harmless birds (MAM 4:649; ARBAE 31:613; IS 4).

Catbird's fishing of his wishes and sojourn under water is a unique Coeur d'Alene supplement to the story of the small one. One or another stylistic feature of Catbird's visit may be found in the typical Quinault myth outlined below, but this sea journey, like the others, has its own distinctive setting.

A deserted girl and her brother obtain much whale meat; the pair embark on a whale with their child; the rest of the people visit under water with them; they 
must follow in the leader's footsteps in order to keep their footing on the slippery beach at the bottom of the sea (MAM 4:97).

In conclusion a stylistic parallel to the fishing of one's wishes out of the water may be pointed out in Ten'a mythology:

All of a family of sisters except the second oldest who was a bad girl, draw in husbands in bags on their fish hooks; they dive into the water to settle in their husbands' village (PAES 6:94).

\section{Skunk and Fisher}

Skunk and Fisher live together; Skunk keeps house and gets only scraps to eat Chipmunk and Squirrel are sent to Fisher

Chipmunk laughs at Skunk's noise

Skunk hides girls

Girls scorn Skunk's food

Fisher keeps up fire and prevents Skunk from visiting girls at night

Fisher and girls desert Skunk

Skunk pursues them, sees their reflection in water and threatens to kill them

Skunk loses his fluid in water

Skunk sends his fluid into Fisher's eye; girls come down to Skunk

Girls run away from Skunk and leave rotten wood in their place

Skunk pursues them; tricks his hosts, leaving his dung to look like camas

Skunk steals baby

Skunk tells people hardluck story

Skunk kills people with his fluid; spots Antelope and Wild Canaries

Skunk cures blindness

Skunk honored as chief

People transformed into stars

Skunk and Fisher lived together. They had lots of deer. They would go hunting in the morning. They would kill two deer. Fisher would clean them and prepare the meat. Skunk would say, "Don't give me any meat, just the entrails, the fat and the meat near the back of the tail. That's all I ever want. You just give me those scraps from now on." Customarily they did that. Fisher hunted and secured plenty of meat but Skunk took only the scraps.

Not far from where they lived there was a village. Eagle was the chief who had two daughters. The younger was Chipmunk, the elder was Squirrel. One day he said to them, "Go to Fisher so he will give you meat." Before they left their mother said, "When you go in look carefully at the meat. What Skunk gets is no good. It's only scraps. Fisher's is the only good meat."

The girls went. They came into the house and sat down. They looked at what Skunk had at the head of his bed, then at what Fisher had. 
Just as it became dark they heard Skunk's noise p'ap'aq'. He made this noise (of breaking wind) every time he took a step. Chipmunk had to laugh at this. Squirrel, her sister, said, "Keep quiet and come under the mat so he cannot see you." Meanwhile Skunk came nearer and Chipmunk was convulsed with giggles. He heard her and saw them. Then he asked, "Did your parents tell you to come to Fisher's bed? There's my bed." He grabbed one of them by the arm and made her go in behind his pillow. Then the other hid there too. Skunk set about making a fire. Soon a noise was heard, tcisasat'at'at'. It was Fisher. Then Squirrel said to her sister, "Didn't I tell you! What a nice noise his is!" Fisher laid down two deer and said to Skunk, "Come, drag them in!" Skunk said, "You make me ashamed. What if someone heard you say that?" Fisher thought, "That's funny! He never said that before." Skunk dragged in the deer and as Fisher cut them up he said, "Give me some of the ribs to cook." Fisher thought, "I won't be stingy. I'll give him some."

He prepared the meat, gave some to Skunk and they both cooked. When the food was done and they were ready to eat Skunk said, "Let's share with our pillows." "What do we want to feed our pillows for?" asked Fisher. "It's all right," said Skunk. He took a dish, put meat in it and set it just behind his pillow. Then he watched it while he and Fisher ate. When they had finished Skunk said, "Let us look." His plate was the same. He told Fisher to look at his. "What do I want to do that for?" "Oh, go ahead."

Fisher looked. The plate was empty. Only bones were left. "My, there must be someone here," said Skunk. Fisher thought, "I wonder why he says that. He never says it other times."

At night they went to bed. Fisher laid a stick on the fire. Skunk said, "You are making it too hot for me." "No, I feel sore, my back hurts." They both lay down near the fire. As the fire died down so that the house was dark Skunk got up. Just as he got near his pillow Fisher kicked the wood and it lighted up the house. So Skunk came back and lay down. Thus Fisher kept it light all night.

In the morning they got up and cooked. Again as they were dishing up the food Skunk said, "Let us share with our pillows." Fisher protested but again they put food near the pillows. When they had finished eating they looked at the dishes they had put near their pillows. Skunk's was the same as before, but on Fisher's plate there were only bones.

Fisher then went out and rolled a disk which made a noise like a bull-roarer. Skunk thought, "He's gone now." Fisher had gone out only to hide near the house in the brush. Then Skunk said to the girls, "Come with me. Fisher is already gone." So Squirrel and Chipmunk went with 
him. He ran around making his noise. Chipmunk always laughed when he did that but Squirrel was quiet. Soon Skunk said, "Go back into the house. I am going away too." Fisher saw him go. When Skunk got out of sight Fisher went in to Skunk's bed where the two girls were hiding. "What are you doing here? Did your people tell you, 'Go to Skunk's?" What were you going to get from him? Look at what he has handed out to him, nothing but disgusting odds and ends." Squirrel said, "Chipmunk laughs too much." Fisher said, "Go over there. We'll leave Skunk. We'll take the meat supply along."

They took the food and burned the house. It made a lot of smoke. They went past the smoke.

Meanwhile Skunk had been eating grass. When he had eaten enough he lay down on his back. He saw the smoke and thought, "The Cayuse must be burning the Coeur d'Alene." Then he noticed that the smoke was near and he got up and ran. As he came closer he saw it was near his own house. As he went over the hill he was sure of it. "Oh the chief's daughters, they may have died," he cried. He ran as fast as he could, but when he got there the house was burned. "The Squirrels died," he cried. He took a stick and stirred the fire thinking, "I might find some bones," but he did not find any. Then he wondered, "What could have become of them?"

He sat down. He thought, "I'll leave. Maybe Fisher will come back at night and then we'll find out." However Fisher did not come back at night. Then Skunk thought, "All over the earth I will go. There is no corner where I will not go."

So he started off. When he had gone far he found tracks of three people, Fisher's between the tracks of the Squirrel girls. Farther on he followed. Then he became thirsty. He saw a cliff and underneath it a spring. He went to drink. "What's the matter?" He saw the Fisher party deep in the water. "You are going to die," said Skunk. "Leave Squirrel and Chipmunk." But Fisher only laughed at him and did not go away.

"All right! You'll all die." So saying he exuded his fluid there in the water. They laughed and he did it again. Then he had no more. His strength had all gone into the water. $\mathrm{He}$ ate again and when he had enough he went back to the water. He lay down. Soon he thought, "I'll do that lying down this time." He lay on his back and looked up at the top of the cliff where he saw the three were sitting.

He got up. He said to the girls, "Leave him! I am going to squirt my fluid into his eyes." They said nothing. They only laughed. Then Fisher said to them, "Go far away. He can't reach me anyway."

They went far away. Then Skunk sent his fluid into Fisher's eye. 
Skunk said to the Squirrel girls, "Jump down!" The girls paid no attention. "Hurry! If you don't come down I'll do the same thing to you."

They came down. They were sorry. Skunk said to them, "What business had you to go with Fisher?" They went away. They camped. At night Skunk ordered "Go fix my bed." The poor girls were obliged to fix Skunk's bed. They chose a smooth spot, they piled grass high for a mattress. Skunk lay down. He said, "You, Squirrel, will be my pillow." The poor thing lay down. "You, Chipmunk get under the calf of my leg for a support." She had to get under his leg. In the morning Skunk was asleep. Chipmunk woke up. She looked at Skunk. His legs were spread out. She said to her sister, "Wake up!" She answered, "I am already awake." "Go get a piece of wood. Put it down here where I am." As her sister put it down she crawled out from under Skunk's head. They put a piece of wood under his legs. Then they ran off.

Skunk kept on sleeping. He finally woke up and said, "Chipmunk, wake up! You have no flesh. You are hard." She paid no attention. Then he threw back his head and called Squirrel. But no, she was not there! There was nothing but a stick of wood. "Now you are going to get it!" he threatened when he found that neither of the girls was there. He ran off, found their tracks and followed them. He came to a place where camas was being baked in a pit. Someone said to him, "Maybe you are Skunk." "So you're here," he said. "I'm hungry for cooked camas." "Yes. You may eat."

The pit was just being uncovered and the food was taken out. He sat at some distance. "Come, sit nearer," he was told. "No just pass a dish over to me here," he said. He took a sack. He dumped the camas on it. He ate. He got up to go. He had some camas tied up for his lunch. Where he had been sitting the people saw some camas which had been spilled. "Look, you spilled some," they told him. "No, I tied it up and fastened it to my belt (like a purse)," he said. Then they asked, "Are you leaving it?" "No, I've already eaten the camas," he said. Then he went away and they found he had left his dung looking like camas.

Again he came to a settlement. Again he did not sit with the people but a little apart. At night something cried. The chief said, "Go see the baby." Someone went. It was dark. Skunk went. He saw there were many houses. He peeped in. He saw all the people passing a baby around from one to the other. He was not seen but he had his two hands cupped and moved in among the people. Then he took the baby. The people said, "Where is it? It is gone!" They scattered. In the morning they saw Skunk. He said to them, "I have something to tell you."

The chief called the people together. "Come we have something to announce." Skunk said, "Sit down. I want to tell you. I just came from 
the Cayuse country. As I passed by the enemy ran after me. There must have been a hundred of them. I did my best but my firstborn was captured. I came on but a hundred and fifty of the enemy attacked me. My secondborn was captured. I kept on running. I crossed the river in the Cayuse country. Then my third child was captured. I'll stop right here. I want to go out."

He got up and just as he got to the door they could see his fists were far apart and he was holding something in them. He squirted his fluid on the door poles. The people all fell back. Skunk was gone. Fox ran out. On the way Skunk had thrown his fluid on Antelope right near the tail. He threw some on the little animals which became wild canaries. That is why their feathers are yellow. He saw Coyote. All the people died. A poor old blind woman like me (the narrator) was standing at the door. "How are you?" said Skunk.

The old woman pointed to her left eye. "Just a little I can see." Skunk sent some fluid in the eye and she could see. Then he threw some into the eye of another old blind woman. "Fine! I can see everything now," she said. "I got my eyes back again." Then Skunk asked the old women, "Are there many people over here?" "Yes," they said. "Carry me back to pay me for curing you," he said. They said, "We'll take you in a canoe." Skunk said to them, "You must respect me as if I were a chief."

$\mathrm{He}$ sat in the canoe in state. One of the old women sat in front of him, the other behind. They moved on. The old woman said, "There is a nice village ; it is white with houses." Skunk said, "Call out! Say, 'Here comes a chief with yellow moccasins. He has stripes at the back of his head and on his back. His eyes and his tail are striped.' "

The people crowded out to the shore. Skunk sat very dignified with his arms folded as if he were a chief. The chief and his people lifted him by the arms ${ }^{1}$ and carried him up to the village. So they went. They made the noise of transformation and became stars. ${ }^{2}$

The end of the road.

The Skunk and Fisher myth has numerous analogues, all of which follow the same general outline. Such myths are found among the Kutenai, Shuswap, Northwest Sahaptin, Coast Salish, Nez Percé, Kathlamet, Quinault, Chilcotin, Achomawi and Coos. The main elements of the individual myths are outlined below:

The grandmother of Chipmunk and Big Chipmunk sends her granddaughters to Fisher; Skunk takes the girls in; Fisher escapes with the girls; Skunk shoots his

${ }^{1}$ The way of showing the highest respect to a hero was to lift him under the arms, raise him high and carry him thus to the house.

${ }^{2}$ They became something other than they were, perhaps stars. 
fluid at them and kills all three; Skunk revives the two girls and takes them for wives; the girls hem Skunk in with rocks, escape and revive Fisher; Skunk escapes from the rock barrier by pushing out his body parts one by one, Raven flying away with his musk bag; Skunk comes to people playing with his musk bag and recovers it (Kutenai BBAE $59: 231$ ).

Two women are sent by their parents to marry Fisher; the women laugh at Skunk's noise and become his wives; Fisher and the women escape to a cliff, leaving wood in their place; Skunk shoots his fluid into the water at the foot of the cliff ; the three up above mock him and he leaves, ashamed (Shuswap MAM $4: 752$ ).

Skunk hides a woman; his housemate, Eagle, takes the woman to a bluff ; Skunk ejects his musk into the water at the base of the bluff; Eagle cuts the rope on which he is hoisting Skunk, Skunk drops into the water and sets out in search of his musk sac which has floated away; he recovers it from people who are playing with it ; he ejects his musk at all the people who had spoken harshly to him; Cougar escapes Skunk; Prairie dog overcomes Skunk by whistling (Northwest Sahaptin UWPA $2: 207)$.

A chief's elder daughter follows the wrong trail and is taken in by Skunk; Skunk's master, Cougar, runs away with the girl beyond the sky; Skunk pursues and shoots his musk into the water; the two up above knock out his anus with hot rocks when he attempts to ascend to them backside up; Skunk follows it down the river and recovers it from people rolling it as a hoop; Skunk shoots his musk at those people who were unkind to him; he is frightened by Skwkwi'kw's whistling, dies and loses his dangerous powers [Skunk kills Cougar; Fox escapes Skunk by whistling; five Wolves render Skunk harmless and revive Cougar] (Upper Chehalis, Cowlitz MAFLS $27: 46,198$ ).

Skunk hides the five Killdeer girls who have come to marry Eagle and sends the five Frog sisters to him instead; Eagle sends the Frog sisters home; Eagle flees to a cliff with the Killdeer girls; Skunk shoots his musk into the water at the foot of the cliff; Eagle knocks out Skunk's musk sac with a hot stone; Skunk recovers his musk sac, is alarmed by his captive's whistling and is killed by the wolves (Nez Percé CUCA $25: 251$ ).

Owl hides the girl sent to his chief, Panther, by Bluejay; after five nights Panther finds the girl and takes her; Owl and Panther fight in the air; the girl puts Panther's bones together and replaces his missing intestines with those of Lynx (Kathlamet BBAE 26:129). [The air-fight or tree-fight, though it has no counterpart in Coeur d'Alene mythology, is a common myth episode, called into service most often in connection with the overpowering of dangerous beings.]

A girl, sent to Owl's house, arrives at Screech Owl's by mistake; the girl flees and hides in a tree; Screech Owl jumps at her reflection in the water and is almost frozen; the girl marries Owl; Screech Owl claims her for his wife; the fifth time Owl and the girl tear Screech Owl to pieces (Quinault MAM 4:122). 
Some girls hide in a house; they laugh at Skunk smelling about for them; Skunk finds and marries them; some men steal them and carry them to a mountain top; Skunk tracks them, ejects his secretion and the mountain falls, killing the men; the girls tire of Skunk and run away to sky country, to return eventually to their mother's house (Chilcotin MAM 4:28).

Two sisters are sent to chief Pine Marten; the younger girl saves her sister from being deceived by Coyote's disguise; Hawk Man takes the two girls in; Hawk Man, given nothing but bones to eat by the people, tries to feed the girls his own flesh; the younger sister discovers his identity; the two girls go to Pine Marten; Hawk Man causes a great rain; Pine Marten has Hawk Man's head cut off (Achomazi JAFL $21: 163$ ).

Two girls, sent to Sea Otter, a great hunter, marry his servant, Old Beaver, by mistake; the girls leave Beaver and marry Sea Otter; when Beaver pursues them, the people kill him (Coos JAFL $22: 35$ ).

Despite the variations to be noted in even the main features of these abstractions, notably in the myth dénouement as compared with that of the Coeur d'Alene story which is not found duplicated, a general framework outlines them all: girls are sent to a person of rank and standing; his servant or inferior takes them in by deceit; they manage to get to the one whom they sought originally; the servant may avenge himself temporarily, but is ultimately overcome. In those myths most similar to the Coeur d'Alene story in which Skunk has the role of the evil-doer, he consistently has certain distinguishing characteristics and features which identify him-his degrading servility, disagreeable noise, dangerous fluid (its loss and recovery), delusion by reflections in the water, treachery to his hosts and talkative, story-telling habit. There is often also his cringing defeat brought about by his victim's whistling, though this is not included in the Coeur d'Alene model. Skunk as a kidnapper and a chief is a distinctly Coeur d'Alene addition. When other characters such as Screech Owl, replace Skunk, they may possess several, generally only the first, of these distinctive Skunk features.

A Kutenai and a Southern Puget Sound story have singled out one major element of the Coeur d'Alene myth for the motivation of a short story.

Skunk pursues Panther (Fox) to a lake; he breaks wind at Panther's reflection in the water; he lies down and discovers Panther up above; before he can act, Panther shoots him [Skunk succeeds in killing Panther in the tree] (Kutenai BBAE $59: 24,41,49$ ).

A girl is warned by Raccoon Woman, slave of Thunderbird and his housemate, Skunk, not to laugh at Skunk's jesting and singing or she will be obliged to become 
Skunk's wife; the girl heeds the warning; Master Hunter marries her (Southern Puget Sound UWPA $3: 106)$.

\section{The Girls Who Stole Dentalia (Kidnapping)}

Chief orders daughters to throw all bones into water and not look at them Daughters disobey and discover bones have turned into dentalia Girls build house in woods

They get threat for stringing dentalia by lying

Chief discovers deceit and deserts daughters

Girls cross river

Younger girl breaks eating taboo and is deserted by older sister

Older girl gives Mudhen dentalium

Mudhen secures girl as wife for her grandson, Redheaded Woodpecker

Baby is born to girl and kidnapped by four man-eating sisters

Mother pursues Man-eaters

Meadowlark directs her

Mother catches full-grown son in sweathouse

Proves motherhood by jumping in her son's tracks and throwing a pailful of water without spilling any

Son leaves dummy behind and flees with mother

Man-eaters pursue

Son and mother cross water on her belt; Man-eaters fall off and are drowned

Man-eaters become terns

Son turns into helldiver

Mother turns into robin

There was a settlement. Many people lived there. The chief had two daughters. ${ }^{1}$ The chief said to the people, "When you eat meat bring the bones over to me."

The people ate. At night they brought him a lot of bones in a bucket. In the morning he said to his daughters, "Go make a hole in the ice, throw the bones into the water, but don't look at them. Just put them in, then go away."

For a while they did just as he said, but one day one of them thought, "I wonder what that noise is, mu mu mu." She thought she would look. As soon as she poured the bones in she looked. The bones had become dentalia. Soon the ice would be full of them. She told her sister about it. They talked it over. "Let's go into the timber and make a house." They did so. They took two sacks full of dentalia to their house. One said to her sister, "Ask all the people for grass thread. You must say, 'My father is asking for it." "

The girl went about and asked for thread from house to house. The people gave her a lot because they thought the chief wanted it. She took it to their house in the timber and strung the dentalia. At night they

${ }^{1}$ In this case the chief and his daughters were said to be Eagles. 
would go home but as soon as they had eaten in the morning they went to the house they had made. After a while the chief thought, "Why do my daughters act that way? They never do any work, just go off and play all day."

He decided to find out. He trailed them to their house. He sneaked over and raised the mat which served for a door. He peeped in and saw the two girls stringing dentalia. He went to see what they had done with the bones. There were none. He was grieved. He went home and called his tribe together

"I want to talk to you, my tribesmen. Not for my own, but for your sake I asked you to bring me the bones. Now my own children have stolen them. That is what grieves me so. It wasn't your children but mine. I will desert them. We'll all go away."

He took off the covering of the house, pulled up the poles and said, "That's where you used to live." Nothing was there. Houses and people were gone.

At night the girls came back as usual. Every fireplace was dark. They went in. "What is the matter? Are you asleep already?" There was not a sound. The ashes were cold. Everyone was gone.

The next morning the girls packed up the dentalia and started off. They came to where a river forked. They saw a house across the water. They called, "Hu ... !" A man came out. "Ferry us across," they asked. He answered, "Uhu $h u h u$, my grandchildren, I have no canoe. There is a ford. Come that way." They crossed. The younger girl said, "I'll fix it."

She laid a dentalium on her chin and said, "If anyone gives us something to eat, put this in your mouth and pass the food through it like a funnel."

They came to a place where the people were cooking blood and stirring it. "We have nothing but this blood for food but you are welcome to it."

The blood was set near them. They ate, the older one passing it through the funnel. The younger girl ate it in the usual way. When they had finished eating they went on. The older got far ahead of her sister. "Hurry, my younger sister," she called. The younger girl caught up but immediately fell far behind. "My steps are not big enough to step in your tracks."

Her sister came back and beat her. "Why didn't you do as I told you. Now I'll take you back." They turned back. There was a ferryman. "Ferry us over, we are going to stay here," they told him. He rowed

\footnotetext{
1 The ferryman, sqwa'xwmenxw, lives near riffles, stands on rocks in water. When he dives he stays down so long one thinks he has drowned. He glitters like a blackbird.
} 
toward them, but when he was still some distance from the shore he said, "Come meet me."

"No, my moccasins will get all wet," said the older sister.

She reached over and ducked him in the water. His eyelids turned back and became white. They threw him into the canoe. She took all the dentalia herself and left.

After some time she heard many people travelling. Of the two girls who had been deserted only one remained. Mudhen was sitting near to the trail along which the girl was coming. She thought she would stay there. When the girl came up Mudhen sat near the trail tanning a buckskin. She folded it up and put it on her back. She decided to go and tell the people the girl was coming. The girl had given her a dentalium and that is why her nose is shaped like one. She ran and caught up with the travellers. She was holding her nose, "Tso tsä nä nä, I am going to see her who was deserted," she said.

"Why are you holding your nose like that?" "The girl paid me." "Let's see!" She let go her nose and they saw it was white and shaped like a dentalium. She said, "She is coming."

The chief said to the men, "You sit around. She'll shake hands with you all. Whichever one of you likes her can have her."

Mudhen ran out. She met the girl and said to her, "You are going to shake hands. Whichever of the men you like you can have. My grandson is handsome. You pick him and go with him. I'll point him out to you. When you shake hands with him pull him. If he doesn't like you I'll push him."

The people sat waiting for her. She began to shake hands. Every time Mudhen thought, "She'll take that one." But no! She came to her grandson, Redheaded Woodpecker. When the girl shook hands Woodpecker jerked back. Mudhen pushed him. "Go with her," she whispered.

He went with the girl and they left the camp. They came to another settlement. The girl had a baby. She made a wide babyboard for it and covered it all over with dentalia. They then dotted it with Woodpecker's head feathers. Everyone liked the baby. Every morning the people took it with them. When he cried they brought him back but left him just long enough to nurse. One night they did not bring him back. The woman was lonesome for her baby and went to the chief. He called, "Bring back the baby. His mother is grieving for him."

They could not find the baby anywhere. Someone said, "At night someone stuck her hands in through the mats of the house. Her hands were sticky. She must be the one who took it." That was the last time it was seen. They found out that four man-eating sisters had the baby. Then the mother took a sackful of dentalia and tracked the monsters. She 
went far. As she was going along she stepped on a stick in the trail, "aninininin, I was going to tell you some news, but you broke my leg." "Oh, I am sorry. I'll fix it again."

She smoothed down the leg. Meadowlark, for it was she, was all right again. Then she said, "I was waiting to tell you. You can't get your child back; he is just like a wild animal." The girl gave Meadowlark Bluebird's necklace as a reward. "You are near him now," she continued. "In the morning the Man-eaters leave home. They round up the animals here. Your child just sits and kills what he wants of the deer. They have a sweathouse. Early in the morning you hide in the mud. There you will get your baby if you think you will live through it. They might kill you. Grab him and do your best to hold on. Tell him, 'I am your mother.'

The woman hid herself near the sweathouse. About two o'clock at night she saw a light being carried to the sweathouse. She sat very near the door. She saw her son who was now a man make a fire. It got redhot. He put rocks in it. He went in feetfirst. She grasped him firmly around the waist. He ran out, " $a n a^{\prime} a n a^{\prime}$, something is hanging on to me. Who are you?" The woman said, "I am your mother, be quiet, I am your mother." "Why should I have more than four mothers?" "I'll show you how it is. Be quiet!" "No. You are an ugly thing!" "Be quiet! I am your mother. It is true what I tell you."

He became quiet. She said, "You have not four mothers, but one. Have you forgotten your real and only mother? My child, you are my only son. One of those others calls you 'daughter's son,' another calls you 'son's son.' That is not the way to call one's real child." "Which of the four is my mother?" "I will keep on saying 'You are my child.' You will never be anything else to me." $\mathrm{He}$ thought, "It must be true." "When you were a baby our people liked you so they were always taking you along with them. You were kidnapped. I trailed the kidnappers and only now I found you."

"Let me go then. I will jump. If it is true you are my mother, you will jump right in my tracks." "Don't run away from me." "No, I only want to prove it."

She let him go. He jumped far. Exactly where he stepped she stepped. Then he said, "Truly you seem to be my mother. Now we'll throw water. If it does not spill, I will believe you are really my mother."

He threw a pailful of water. She threw it also and not a drop spilled out. "Yes, it must be true. My mothers are not real people. They will find out and will kill you. I'll sweat here. Then I'll go to them and say, 'You sleepyheads, you are still asleep.' I'll say, 'Eat!' After they have eaten they will leave. Then I'll round up the animals. I'll sit over there. 
We'll make a dummy. We'll put my coat and hat on him and give him an arrow. They'll see it and come back. You go to the house and eat lots of meat. I'll come in and say, 'Get up, my mother!'

" 'What is the matter? Your mother must have come,' they will say. I will say, 'Have I a mother?' My mother's mother will say, 'I'm just saying that.' My father's mother will say, 'Hurry up! His mother must have caught up with us. He never talks like that.' I will say again, 'Have I a mother ?' Go on, you women. They will say, 'Boy, you sound guilty." ",

They fixed the dummy as if he were ready to shoot. The four Maneaters would make a pile of grass, then set fire to it and make a thick smoke. They would fly up to disguise their tracks and light again. They rounded up the animals toward the boy. They said, "Shoot!" He did not shoot. The animals all ran away. One said, "I am going to teach you a lesson." They caught up with him and hit him with a stick which went all to pieces. "It was all in vain," they said.

They looked back. "I suspected his mother was behind all this," said one. "He talked senseless this morning. There is no place we do not know on the earth. We ought to be able to find her." They went back to their house. They trailed the boy and his mother. The boy said, "They are following us. Let's cross the water."

The mother untied her belt. She threw it across the water and they walked across on it. She put it on again. The Man-eaters saw them crossing. "You have tired us all out. We'll get you," they threatened. "You'll die." The boy and his mother went on. "Where did you cross?" asked the Man-eaters."

"Since you intend to murder us we won't help you across. Those who are angry enough can find a way of their own. Untie your belts and cross the way we did." One tried it but the belt floated. Again the Man-eaters urged the woman to throw her belt down. "No, not when you are going to kill us," she called back. "We are not going to kill you. We only want to shake hands with your son and with you."

She untied her belt and threw it on the waves. They started to cross. "No, its too wobbly!" The mother said, "Put rocks inside your clothes. Then it will be steady." They filled their clothes with rocks. It was heavy, but it stood firm. As they crossed the mother pulled her belt toward her. "Stop pulling," they cried, but she kept on. In the middle they sank. They came up on the other side as terns. "You'll no longer be maneaters. You'll be animals which live along the river. When people come you will not fly up."

The mother and her son went into the hills at the edge of the cliffs. The mother got thirsty and said, "Come get me some water." The boy went down to the water and played, bathing and idling a long time. 
"Come, I'm thirsty!" He brought the water. She drank. This happened several times. Then the mother said to her son, "I want to talk to you. Go fast through this timber. I feel as if I were going to die. We'll separate now. It was good to see you again." He said, "All right!" "You will be Helldiver, I will be Robin. You like the water too well to live with me."

She cut up dentalia and threw them over him. The rest she threw on herself. That is why robin has white streaks. Helldiver has streaks also. She said, "When the wind blows, you will fly. You will make the sound 'yaxa yaxa'. ${ }^{1}$ As for me, I will be a ghost. I will sit on a tree near the houses of people and make my sound there when people have a death. Since you like water you will live in water. As for me I will live in the brush. Good day."

That is the end of the road.

The Kutenai interweave the two stories of The Girls Who Stole Dentalia and the Story of Lynx (tale 9) into one myth:

Young Buck orders his relatives to throw the soft part of rib bones into the water; his sisters, Fawn and Young Doe, disobey and take the bones which have turned into dentalia out of the water; Buck takes all the people down a hole and deserts his sisters; he refuses to let them come down to him; the girls cross a river on stilts and enter Water Ousel's tipi; Fawn swallows the blood Water Ousel gives them to eat; she misses a step while following in her sister's tracks and gives birth to a fawn; Young Doe sends her back to Water Ousel ; Fawn holds Water Ousel under water to punish him; Young Doe approaches a settlement; Rabbit waylays her on the trail and, when addressed as husband, takes her to his grandmother, Frog, who hides her; Lynx secretly impregnates her, she has a baby, the three are deserted, Lynx kills many deer and the starving people return to them; Lynx's child is lent around among the people; Toad and Owl stretch out their hands for the child and kidnap it; Young Doe follows them, takes back her boy and flees up a tree with him with the kidnappers in pursuit; she calls her dog, Grizzly Bear, who bites Toad and Owl and eats their dog, a mouse; Doe reaches home with her child; she and Lynx have another son and the two boys become the sun and the moon (Dyer).

A Thompson myth similarly opens with an introduction resembling that of the Coeur d'Alene story, but the adventures of the girls deserted for their violation of a taboo proceed along different lines to culminate once again, as in the Kutenai myth, in a direct parallel to the Coeur d'Alene Lynx story.

A man instructs his two sisters not to visit his bathing place; the girls disobey and discover the dentalia which have come from needles from their brother's sponge;

${ }^{1}$ When people hear helldiver they say wind is going to blow. 
they take the dentalia; their brother leaves them and goes to the lower world; the girls are unable to descend, for they break the taboo and open their eyes; their brother sends them to their aunt's home, the younger girl breaks the taboo and stops off at Coyote's house, where she eats and becomes pregnant; she is deserted by her older sister; Elk, the older girl's aunt, overtakes her in a race with young men and hides her from them; Lynx spits down upon the girl and impregnates her (MAM 12:213).

In a briefer Thompson version the brother takes pity upon his deserted sisters who are unable to descend to him in the lower world and returns to live with them (MAM 12:373).

A third Thompson variant leaves no basis for comparison with the Coeur d'Alene model, except in breaking the taboo and desertion:

An older sister, annoyed by many suitors, sets out with her younger sister for her grandmother's house; Coyote makes it so cold, the younger girl insists on entering his house four times to warm herself; Coyote impregnates her; her sister leaves her behind; the elder girl's grandmother hides her granddaughter from the men who are racing for her; Lynx impregnates the girl (MAFLS 6:36).

The element of drowning an enemy while he is crossing the water in pursuit of his prey has a wide distribution. A typical example from Thompson mythology in which, as in the Coeur d'Alene model, a belt is the medium for the crossing, is recorded bellow.

A youth, fleeing with the daughter of a man of magic power, throws his belt down and crosses the lake upon it; the girl's parents follow in pursuit; the girl gives the belt a twist and her parents are thrown into the water; they turn into ducks (MAM 12:291). In a variant, the boy draws in the belt so that the girl's father is unable to cross (MAM 12:383).

Beyond the story of the theft of Young Doe's child in the Kutenai myth outlined above, no further duplications of the Coeur d'Alene kidnapping episode were found in the myth bodies under consideration in this study. The account of the theft of a baby by Lion and Crane as told in an Upper Chehalis myth takes a different turn. After the boy has escaped with Crane's assistance from his captor, Lion, he arrives in heaven; here he obtains a wife and becomes the father of twins born stuck together; he eventually returns to earth to his mother and brother. Bluejay separates the twins who die (MAFLS $27: 83$ ).

\section{Thunder}

Thunder kidnaps hunter's wife

Hunter looks for wife

Four men give him needles 
He climbs cliff with aid of needles, Chipmunk, Gray Squirrel, Squirrel and feathers Finds wife in Thunder's home

Woman hides husband

Thunder sleeps

Woman escapes with husband, taking Thunder's shirts

Thunder helpless without shirts

There was a man who would go away in the daytime. In the evening he would come back. His wife was visited by Thunder when he was gone. One day he said, "I'm coming for you." He took her. In the evening the husband came back. His wife was gone. He sat down and thought, "I wonder where she went."

After I don't know how many days he thought, "I'll go look for my wife." He went. Far he went. He came to a house and went in. He was said to, "Ah! Are you looking for your wife?" "Yes!" "You poor thing! You'll never see her again. Thunder took her." "All right! I'm going to search for her."

The owner of the house gave him four small needles. "Go in that direction," he directed. He went. He came to a house and went in. "Are you looking for your wife?" he was asked. "Yes." "You are to be pitied, you'll never see her again." "All right! I am looking for her."

This one also gave him four needles. He told the man, "My older brother will point it out to you." He went on, far he went. He came to a house and the same conversation was held. $\mathrm{He}$ was given four needles.

A fourth time it happened. "Thunder has your wife. You'll never catch him," he was warned. "They gave you those things for nothing. Go on. Not far from here you'll see a cliff. There use the needles. If it wastes away do not leave it. The cliff is high. If you could climb to the top you might see your wife, but you will never get there." "All right! I'll go."

He saw the cliff. He took out a needle and stuck it into the rock. $\mathrm{He}$ took out another and stuck it in, and thus with a third and a fourth. Then they were all used and he saw no woman. Now there was nothing against the rock. ${ }^{1}$

Soon Chipmunk hopped into sight, patatsatatsatatsat, up the cliff she leaped. "Please help me get to my goal," begged the man. "Take me to the top. Have pity on me. My fingernails are all worn down to the flesh." She said, "Hold on to my tail." He held on to her tail. She leaped up, patatsatatsatatsat. They had not gone far when she complained of her fingernails. The man took out a needle. Then Chipmunk ran away.

${ }^{1}$ The needles must have made a magic ladder. 
Soon he saw something against the rock. It was Squirrel leaping along. "Take pity on me. See how my fingernails are worn down." "Take hold of my tail." He took her tail. She leaped among the rocks. She had not gone far when she said, "My fingernails are worn close." He took out a needle and begged piteously. This time Squirrel came leaping, nat nat, and told him to hold her tail. Thus they climbed until she was worn out. He took out a needle and hung back. Soon feathers came. He said to them, "Help me!" "Long ago you should have asked me. Take hold of me."

He took hold. They were blown to the rock and touched it, then they were blown away again. Four times they blew out and back. ${ }^{1}$ Then they were at the top. The feathers said, "Go! The rest you can climb alone. The one who is there is not a person. He will kill you. You will see all the trees broken from lightning. That is because he goes hunting and when he returns at night and comes into the house lightning hits the trees. The woman is there. He takes her by the arms and throws her aside and says, 'Your husband is on earth.' Then he digs and digs in vain. At last he will be quiet. All right then. Go! You may see your wife."

He went, he went far. He saw splintered trees, rocks broken in two and at last a house. He went in and saw his wife sitting there. "You. are dead. No longer are you a person." She said, "Sit down. Eat well. If you die it will be good. It is easy to know when he is coming. The food is ready for him." He finished eating.

The woman said, "We'll make a hole under the bed. You sit in the hole. If he says, 'It is not true there is no one in the hole,' and throws me aside and digs, just keep still. After his excitement he will quiet down. Then I'll cook. We'll eat. Then he'll talk nicely. He'll laugh and tell me stories. At night we'll sleep. I'll tell stories, I'll talk and laugh until he is asleep. I'll tickle him to prove he is fast asleep. Then I'll dig you out. You come out and we'll go away."

Just as Thunder was going to sleep the woman tickled him. But he was snoring $x u \quad x u x u$. She jumped up and dug out her husband. She said to him, "When he goes to bed he hangs up his shirt." All the old shirts were hanging on the wall. The woman took all of them, old and new, along. She threw the old ones away, saying, "They are all torn."

They ran to the edge of the cliff. The woman put on the good shirt. (Interpolation by informant, "I don't know, I think her husband hung on her belt.") They flew. They went to the earth. She took off the shirt, told it, "Be torn in pieces," and threw it away. They went to their house.

1 The feathers were so light they were blown in so they touched the cliff, then out again. 
Meanwhile Thunder slept. He woke. The woman was gone. He got up and saw the hole. He said, "There's no place I don't know. You are going to die." He went to get his shirt. It was gone. The old ones were gone as well as the new one. He flopped down. He cried.

The end of the trail.

In the numerous myths of neighboring tribes concerned with the kidnapping of a man's wife, including the Thunder Bird stories, there is no development of plot corresponding to that of the Coeur d'Alene myth, where Thunder is the kidnapper.

An isolated example of the ascent by means of feathers, placed in a different setting, may be noted among the Chilcotin, two examples of sky people's helplessness when deprived of their clothes are found in Kathlamet and Quinault mythology:

A boy wishes to reach the sky in order to get wives from the sun; the boy has his sister blow on a pile of duck feathers, which thereupon carry him aloft (the boy obtains the sun's two daughters for wives; however he forgets to thank an old woman helper in the sky so his wives are taken away from him again) (Chilcotin MAM 4:24).

The Earth people attack the Southwest Winds in the sky; the Sky Women are unable to flee, for they cannot put on their coats; the coat-strings have been cut; the Earth People kill the Sky Women (Kathlamet BBAE 26:70).

The Earth People attack the Sky People in order to recover Raven's daughter who had wished for a star husband and awakened in the sky; the Sky Women cannot fasten on their clothes, in which to run away, for the girdles and fastenings have been cut; they are obliged to stay (the Earth People retreat down the arrow chain with the girl; it breaks; they are left hanging in the sky as stars) (Quinault MAM $4: 109$ ).

\section{Waterbird Contests for Woman (Gift Test)}

Waterbird is insulted by girl

Girl gives him ring and handkerchief and sets date for his return

Waterbird forgets date

Waterbird hurries to girl's house and becomes dish-washer

Girl tests suitors by handkerchief and ring

Waterbird becomes girl's husband

Waterbird does all the work

Four rattlesnakes steal girl

Four Thunders burst Snakes' rock and destroy Snakes

Girl restored to Waterbird

Waterbird lived with his mother. One morning he went along the river looking for salmon. Suddenly he was said to, "The chief is looking for 
a rotten salmon." A woman on the other side of the river said it. Waterbird was very much ashamed. The next day the same thing happened. He thought, "I'll go get her." He went and found she was very pretty. She gave him a ring and a handkerchief, both of which were very unusual and expensive. He took them and put them in his pocket with the corner of the handkerchief showing. She set a day when he was to return to her.

$\mathrm{He}$ forgot all about what she told him. After about two weeks or more his mother said to him, "They are having a celebration. I think they must have taken your girl." Then he remembered what the girl had told him and was so excited he nearly cried. He got ready and walked all night. He came to her house. The people were showing their things. The chief said, "Tomorrow absolutely all of you come!" The next day all got ready. Waterbird said nothing. He had become a kitchen boy and was washing dishes for the cook. The people all showed their handkerchiefs and rings but none was the right one. Then the cook said, "I have a dishwasher who stayed home." The people talked over the matter. "Go call him!" they said. "Tell him to bring his handkerchief and ring."

After that they all displayed their goods, but the girl's handkerchief was not among them. Then Waterbird stood up. My! he was handsome. Strange he looked, not at all like the dishwasher. No one recognized him. He took out the handkerchief and gave it to the woman. "This is mine," she said, "You may go now. This is the one I will take for my partner."

Waterbird took the woman home to his mother. In about two weeks he got tired because he had to do all the work. The girl did nothing. He cooked, fetched wood and did everything. One day he said to her, "Go bring in the wood. It is already tied up ready to pack."

He went out. When he came in again to look for her she was gone. Four rattlesnakes had taken her away. He went into the house, lay down, covered his head with a blanket and mourned four days. Then he said to his mother, "Go get bark from a pine tree and tie up four bundles of pine bark."

She brought back the four parcels of pinebark. Then he got up, washed his face, took his little coat, went out and waved it giving a warwhoop. Four times he waved it. Thunder spoke warara in the sky and four Thunders came down. They were his mother's brothers. "Why did you call us?" "I want you to eat," he said and gave each a parcel of pine bark. ${ }^{1}$

${ }^{1}$ The Thunders must like pine bark because Lightning peels off the bark at a certain season of the year. Lightning and Thunder are the same. 
"My! Thank you!" they said because they liked it. They laughed. They were glad. When they had finished eating Waterbird said, "I want you to get my wife back for me. The rattlesnakes took her." The eldest Thunder said, "We know it, but it is impossble. They live in a rock." Then Waterbird cried and begged, "Please get her back for me." The youngest Thunder said, "Yes, let's get her for him."

They took Waterbird to the door of the Snake's house. There the girl was, tied with a chain under her arms and fastened to the wall with a lock. The Snakes were warned, "Waterbird is coming after the woman." "No, no, it is not easy to give her up." The father snake said, "Give her back to Waterbird. His uncles are awful."

Snake refused. Then the eldest Thunder rose and talked, war war. He struck the rock. Pieces of the rock flew off. The Snakes laughed. The second Thunder rose and spoke war war. Parts of the cave door broke off. Again the Snake laughed. The third Thunder went up and spoke. The Snakes' mother and father cried and begged, "Go give her back to Waterbird." Then the youngest Thunder put Waterbird close to the door and threatened, "If you don't give her up you'll die." "No," they refused and laughed mockingly.

Then he went up. He struck everywhere so the rock crumbled. The Snakes were killed. Only the woman was left. Waterbird took her and the Thunders took them all back to his mother's house. They told him, "Now you do not need to watch her any more. Let her go." Waterbird said to her, "Bathe for four days because you smell awful." She did so and then she was his alone.

That is the end.

There are no parallels for this Coeur d'Alene myth with its borrowed European elements in its entirety. Two examples from Shuswap mythology, similarly derived from European folklore, are significant for comparative purposes. Each contains the test element as a method of identification.

Alamer rescues two girls from a chief who had stolen them; the girls give Alamer a ring and a silk handkerchief; hostile chiefs set Alamer adrift; Fox helps Alamer ashore; Alamer produces the ring and handkerchief and claims the two girls; the hostile chiefs are killed; Alamer takes one girl for his wife, his helper receives the other (MAM $4: 732$ ).

Sna'naz rescues the chief's daughters from Seven Heads, the Cannibal, and cuts out Seven Head's seven tongues; a slave finds Seven Heads dead, takes credit for the victory and claims the hand of the girl; the girl examines her suitors, but fails to identify her rescuer among them; she recognizes an ugly stranger sitting in the 
kitchen; the stranger, Sna'naz, produces the seven tongues; Sna'naz becomes the girl's husband (MAM $4: 755$ ).

There is however in a Kutenai Thunder Bird story a close parallel for the last un-European part of the Coeur d'Alene myth, the theft of the hero's wife by the rattlesnakes. The correspondence to be noted between these two narratives is especially satisfying because of the tendency of the one myth to elucidate the vague points in the other, and vice versa:

A boy, whose father had disappeared, takes for a wife a chief's elder daughter who said she would never marry; he is warned not to have her do outside work; one day the girl fetches water for her husband and disappears; the boy has his grandmother prepare for visitors; he dresses up and paints himself; three spirits similarly decorated arrive; lightning darts from their pipe smoke, each of the three disappears; they await the boy on a mountain top; they help him to open up a large rock; he sees his wife inside surrounded by rattlesnakes; the spirits burst the snakes' rock with their lightning; the boy recovers his wife and becomes her boss; the girl had had the spirit of the rattlesnake and it was that which had told her not to marry (Dyer).

\section{Water Monster Woman}

A boy pokes out eyes of children

Boy and his sister deserted

Boy pokes out eyes of animals

Sister leaves him

Boy fishes up abnormal fish, Water Monster Woman who eats people

His grandfather, Fox, warns him

Boy and family visit Water Woman's under-water country

Water Monsters try to kill guests

Four bushes save visitors from drowning; they return home safely

There were children. They would go far away from the other people and play in the morning. A boy saw them. He would quarrel with them and, for no reason, become angry and poke their eyes with something sharp he had. Then each child had only one eye. His father said to the people, "It is really too bad. You must grieve, you who have children. Let us leave him with no one but his sister."

The boy had not poked out his sister's eyes. The father told the sister to take her brother to be bitten by Grizzly. She went with her brother. The people left. The boy sat down. The girl drove the animals toward him, Grizzly Bear, Black Bear, Wolf and Cougar. The boy poked out their eyes one after another. All the animals were one-eyed, all but Grizzly. 
The girl ran home. Grizzly ran straight toward the boy who poked his eye out. As Grizzly was dying he called to the girl, "Is this the one you mean?" Grizzly had sandals of wood. The boy sat and wondered where his sister had gone. He went to find her. He found tracks which showed she was running. He thought, "If I ever get to the house I'll punch her eye out too. She's absolutely no good."

He came to the house and went in. She was not there. He went into the neighbor's houses but she was not there. He sat down and cried. At night he went to the sweathouse and stayed. In the morning Magpie suddenly came to the door. He punched out her eye, skinned her and hung the skin by the door to dry. $\mathrm{He}$ did this to ten magpies. $\mathrm{He}$ ate the meat. The skins he sewed together and made himself a blanket. $\mathrm{He}$ was glad and danced.

A monster who had two daughters said to the youngest, "Go, get him for our food." The boy got hungry. He thought, "It's true there are many fish in the river. I'll fish and get some." He fished. He got many fish but all were abnormal; some were halves, some quarters, all were queer. Once again he pulled the line. It resisted; a woman came up. She sat there with the hook in her mouth. The boy was frightened and ran. He ran fast and came to a row of houses. He ran into the last one. His mother's father, Fox, lived there. He told Fox, "I had a bite, it was a woman. She was sitting there when I ran back." Fox said, "Your luck has changed. You will have bad luck." He called the people to go with him to see the woman. When they came up to her old man Fox said to her, "You are enjoying yourself. You are coveting a person (to eat)."

Then he broke off the hook. The grandfather told the boy, "You will stay here always." The boy and Water Monster Woman had a child. He grew large and fat. Then the woman thought, "Even if they are fat they are no more than just enough for my father and mother to eat." She pretended she was angry. She lay there and would not talk. The boy said to his grandfather, "She's angry. I wonder why she won't talk." $\mathrm{He}$ answered, "She has gathered enough people to eat, that's why."

He said to the woman, "Well, we'll all go with you to your family." She was pleased. She got up and cooked. When they had finished eating they started. The woman took the child. Fox's daughter grabbed him away from his mother. The canoe was launched. In front sat the water monster child, next was Fox's daughter, then the boy and Fox.

Just as they were starting into the Water Monster Boy looked back at the others. Fox was told, "He is looking back" (this sounds mean). "Hurry!" he said. They dived, the canoe with all its occupants, just as they were. Four times it dived. Then they came safely to a house. My! they were surprised and frightened. Everything was ice from the river 
to the house. It was very slippery. Water Monster Boy ran up the beach and into the house. The others were wondering how to get up when Fox's daughter sprinkled the ice with red paint. Then they could walk. They went into the house.

"Give me the child," said one of the women. "No, let me take it," said its grandmother. The mother said, "No, no!"

The monster's father said they would eat. Pitch was lighted and put on the fire but, since the wood was from trees belonging to the poplar family it was wet, so it was dark. For a while the father waited. Then he thought, "They're dead. Our guests are full."

$\mathrm{He}$ opened the door, went out and brought light in. The Foxes were sitting there eating. In the afternoon about sunset the father proposed to go fishing with torches. Fox's daughter was sent for pitch. She brought in four bundles. Fox went out and hired four bushes, one whose branches were tangled, one with braided branches, the serviceberry and the thornberry, to act as his harpoonbearers (sic!).

Fox and the boy went in the canoe. Fox's daughter stayed home with the little one. They speared fish. All were abnormal; they were only halves or quarters. Suddenly in the midst of them was Water Monster Woman, the daughter of Water Monster. She said to them, "Don't spear me, I might drag you down." "We're not looking for such as you."

They cursed her, then speared her. They were all engulfed in a whirlpool. Fox's daughter called out, "You smart talker, you Fox!" The serviceberry bush broke, the braided one held them up, when it gave out the thornberry bush helped, just the torch and the harpoon were in sight. It broke and Fox thought, "We're done for! If we are not saved we die." The tangled bush came to the rescue.

A monster came to the top of the water. Monster Woman was crying, she was ordered to stop. "Soon they will bring him back, then we will kill them all. Keep still and do not look at them."

They cut off the hands and feet and took them ashore in the canoe. When they got to the shore Fox's daughter was sitting in the canoe. Fox said to the boy, "Go, throw their hands and feet in." He threw them in. Then he ordered the people, "Take them, eat your dirty filth, you horrid things."

The old Monster became angry. The others became tired following them. Only the daughter followed. Then they came to the shore. They turned the canoe over. They looked around. Soon Water Monster's daughter came to the surface. Fox said, "Go back home or we might kill you too."

That's the end of the trail. 
A number of close parallels may be found for the isolated elements of the Coeur d'Alene myth and, in a Kutenai and a Nez Percé story at least, the combination of these elements resembles the Coeur d'Alene whole in the visit to the under-water country:

Fox and Coyote win Salmon's sister in gambling with Salmon; the Salmon Woman becomes Coyote's son's wife; Fox accompanies Coyote, Coyote's son, Salmon Woman and their child on a visit to the salmon country; the woman tries twice to drown them but they are saved in a bladder belonging to Fox; Fox throws tobacco on the shore so they can ascend; the salmon people try to kill the guests by manuring and smoking them; Coyote dodges two people striking at him with hammers; Fox kills Salmon; when Fox throws Salmon's head overboard to the pursuers, his party escapes (Kutenai BBAE 59:153).

Young Coyote defeats Sea Monster Boy at hoop spearing and wins his sister for a wife; Fox accompanies Young Coyote, Sea Monster Woman, their baby and Old Coyote downstream; Sea Monster Woman tries to drown her companions but they are saved in a pipe belonging to Fox; Young Coyote spears Sea Monster and his brother-in-law; he throws his spear at Sea Monster Woman; a flood pursues the party, until they throw Sea Monster Woman's baby into the water to her ( Nez Percé CUCA 25:48).

In an episode of the Bella Coola Raven cycle Raven fishes up a large fish which turns into a woman; Raven marries her with the promise not to look at another woman; he catches much salmon; he looks after a pretty girl; his wife leaves with all the salmon (IS 246).

A sea story of the Bella Bella tells of difficulties encountered under the water, comparable to those in the Coeur d'Alene myth:

Four men in a boat anchor on the roof of Komokoa's house; Komokoa fetches them down; they are warned by Mouse Woman not to eat the food served them; they paint their boat with a magic potion so that the sea-monster will not swallow it; all the fish enter the house filling it up with water which the snapping-door monster sucks in; the four men throw poison in the water and escape; they are carried up to the water's surface by three whales (IS 238).

The eye-gouging episode of the Coeur d'Alene myth is widely distributed in diverse myths of other tribes, numbering the Tlingit, Tsimshian, Kwakiutl, Haida and Coast Salish-Upper Chehalis, Shokomish and Cozolitz:

A man sees a woman floating with two children on the lake; he takes one child home with him; the child picks out people's eyes; a woman kills the boy and becomes the creature, the sight of whom makes people wealthy [the child disappears at daylight; only one sick woman and her child survive] (Tlingit BBAE 39:292, 174 ; ARBAE 31 :948). 
The son of a prince and a woman of the lake pluck out people's eyes; the prince returns the child to the lake woman and receives from her gambling-sticks which bring him much wealth; the lake woman gives the princess a garment of wealth, the sight of which makes people wealthy; the lake woman becomes part-fish, partwoman ( $T$ simshian ARBAE $31: 156$ ).

A woman marries a water spirit; the child from this union kills people and plucks out and roasts their eyes; the boy's uncle kills him; his ashes turn into mosquitoes and small flies (Krakiutl IS 164).

Half Rock Being (a man in the corner of the house) sees Raven in the skin of a child of the heavenly chief's daughter knead and eat something; the following morning the inhabitants of four towns have each lost an eye; Raven, the eyegouger, is put into his cradle and dropped into the water [Raven is thrown down to earth] (Haida BBAE $29: 111,143$; ARBAE $31: 948$ ).

In an Upper Chehalis myth the daughter of the girl whom the One-Legged Man carried off pulls out a child's eye at each of four places and is sent downstream in a bucket in each case; the fifth time a giant takes her for his wife (MAFLS $27: 121$ ). In a Skokomish version the daughter of the girl taken home by the Sharptailed Man scratches people's eyes out and is paddled out to sea by the Crows in their canoe; the girl, deserted on an island, helps the slave, Coon, dig roots and marries Coon's master (MAFLS $27: 371$ ). In a Cowlitz myth Samlic's wife is carried away by a dangerous being, a cloud; she has a daughter by him who five times tears out a child's eye and eats it; the fifth time the girl rises as a small cloud (MAFLS $27: 196$ ).

In each of these versions, with the exception of the incident taken from the Haida Raven cycle, the eye-gouging child is the offspring of an unusual, mythical parent, in the majority of cases one associated with the water.

\section{Little Mosquito}

The youngest of five mosquitoes receives warning of enemy's presence and hides in sweathouse

Little Mosquito's four brothers are burned to death by Geese

Little Mosquito deserted

Little Mosquito refuses blood mixed with camas

Geese feed Little Mosquito blood

Little Mosquito flies against pine needles and bursts

Mosquitoes are no longer to be man-eaters

There lived long ago a family of four mosquitoes. ${ }^{1}$ The oldest ones always went hunting but the youngest stayed home. They never ate any

${ }^{1}$ This happened at Coeur d'Alene where the trail is dense with undergrowth and full of mosquitoes. 
meat but only blood which was kept in the paunch of a deer. The oldest brothers were tired one time and sent the youngest for the paunch of blood which they had hung on a tree. As he ran along he heard someone say, "Kill the little mosquito because he likes blood." He ran fast and got the paunch of blood. As he returned with it on his back he heard someone say, "Do not kill him right now." Whereupon he ran all the faster. On the other side of the road he heard, "Don't frighten him now, you will scare his brothers." When he came back all out of breath it was dark. His grandmother asked him what was the matter. He said, "I saw something." The brothers said, "What did you see?" He said, "Someone said, 'Kill the youngest mosquito." They said, "You are lying. You are hearing your own breath, that is what you are scared about. Eat blood so you will grow fast," but he did not eat.

After eating the brothers slept. Little Mosquito went out of the house into the sweathouse. When it was very late he heard sounds as of burning and saw that the house was in flames. He was sad. He heard the bodies of his four brothers and his grandmother burst one after another.

After a while the geese who burned the house began to talk to one another. "I told you not to tell him you would kill him," said one, "let's look in the sweathouse for him. Where else could he be hiding? Break off a branch of the thornbush and swing it around in the sweathouse."

Little Mosquito took some red paint and mixed it with spittle in his little spoon. Every time the thorn branch passed him he smeared it with the paint. When the enemy took it out they said, "It is stained with blood. Now we have killed them all." So they left.

When it became light Little Mosquito went to the house. He saw the bones of his brothers and cried. He was all alone. He had nothing to eat, no home, no blanket. One whole day he did nothing but weep. Finally he stopped and went to the lake and washed his face. He thought, "If I stay I'll die because everything is gone. At night I will surely die of cold. If I row away it will be the same. If I go I'll die, if I stay I'll die."

He reached into the water and drew out a monster. He cut open the throat and made a boat ${ }^{1}$ of it. He got in and paddled, crying all the time. The enemy heard him suddenly stop crying. One said to the others, "My! you didn't kill him." One of them said, "Here is some blood. He likes that." They said to him, "Here is blood mixed with cooked camas, come and have some to eat." He said, "I never ate it."

One of the geese said, "He doesn't like the mixture, give him pure blood. That is what he eats." They called to him, "It isn't mixed." $\mathrm{He}$

${ }^{1}$ There is a part of a fish monster's throat or head which looks like a canoe. 
rowed toward them. They said, "Here are four buckets full of blood." Then he rowed to shore and tied up his boat.

They set the four pails full of blood before him and he ate every bit. Then the enemy told him, "The children pushed your canoe away." Then they stuffed the crevices of the house with pine needles. He said, "Tell the children to bring my canoe back to shore." They said, "No, go get it yourself."

After Little Mosquito had eaten he stood up. A goose was standing in the doorway. He said, "Move away," but the person remained standing. He flew up to the hole to get out, but he ran into the pine needles and burst. The blood flew all over and a whole lot of mosquitoes flew out. The enemy said to him, "Go, don't be man-eaters any more. You can annoy people. When they slap you you will die. But don't kill people."

Parallel myths are included in the mythology of the Kutenai, Nez Percé and the Cowritz.

Mosquito's three elder brothers send him to fetch water; he hears enemies about and warns his brothers; he hides in the sweathouse; his brothers are killed by the enemy; Mosquito is deserted; he makes a canoe and starts downriver; he refuses bitterroot, suscatoon and chokecherries, at three enemy camps along the way; at a fourth camp he is fed blood; his belly swells up; he jumps into the pine branches separating his boat from the shore and the pine needles cause his stomach to burst; he shall no longer be a man-eater but a harmless mosquito (Kutenai Dyer).

Mosquito goes along; he refuses to eat chokecherries and serviceberries at the two towns he passes; he comes to a third town and eats much blood there; sticks pierce his belly and he dies; mosquitoes fly out of him (Kutenai BBAE 59:25).

Mosquito bites his grandmother to death and sucks up her blood; he refuses root food; Coyote feeds him five pails full of blood; he stumbles on grass burned to stubble and bursts open; mosquitoes no longer bite to kill (Nez Percé CUCA $25: 13)$.

Mosquito, a dangerous being, refuses duck, wild goose, rabbit and deer-broth stew; five men feed him a potful of their blood, then poke him in the stomach; he bursts; a mosquito just sucks people ever since (Cowvlitz MAFLS 27 :213).

The transformation of the ashes of slain man-eaters into mosquitoes is a common device; one of numerous typical examples may be cited from Kwakiutl mythology where the son of a water spirit slays all the people he meets; his uncle finally kills him, burns his corpse and blows upon the ashes, transforming them into mosquitoes (IS 164). 


\section{Grizaly and His Brothers-in-Law}

Grizzly Bear has three brothers-in-law; the two elder hate him, the youngest likes him

Grizzly's elder brothers-in-law plan to kill him

Grizzly's youngest brother-in-law warns him and saves him

All are transformed into the Great Bear constellation

Grizzly Bear lived with his wife and three brothers-in-law. The youngest of the brothers-in-law liked Grizzly, the others hated him. They thought it was mean the way he bit people and became angry so easily. So the two brothers-in-law said, "Let's kill him. What's he after anyway? Probably something to eat."

They tracked him. Then they saw him standing. They took up their places, first the oldest, then the second and the youngest, last. The eldest gave orders, "All get ready so if one shoots all will shoot together."

They went on, the two oldest close together ahead, but the youngest lagged behind at a distance because he liked Grizzly. When they came close the first two got ready to shoot at him. The youngest watched and just as the string was about to twang he said, "My brother-in-law! You are going to be shot."

Grizzly turned around and just as he was warned he made the noise of transformation.

They all went to the sky as stars and now we see them up there.

(The four stars which form the cup of the Great Dipper are Grizzly's feet. The northern one moved and made the track formed by it and the star immediately above it. The three stars of the handle are the brothersin-law, the one nearest the cup is the one who liked Grizzly best.)

Transformation into stars may be found also in the mythology of the Thompson. In a footnote to the Thompson myth Teit makes the statement: All the Shuswap and Thompson tell stories of the transformation of hunters or men and a bear into the constellation the Great Bear (MAFLS $11: 16$ ).

The Coeur d'Alene Grizzly Bear-Brother-in-law introduction to the transformation has no parallel in the Thompson myth, which is rather the typical concluding episode of a Transformer cycle-the Transformers, having completed their work, are transformed into something permanent (usually in the Northwest into a rock; cp. tale 8) :

Qwa'qtqwetł and his three brothers (three Black Bear hunters) finish their transforming tasks and, accompanied by their dog, hunt a bear in the sky (the eldest brother hangs back afraid) ; the entire group is transformed by the youngest brother into the Grizzly Bear constellation (MAM 12:224; ARBAE $31: 615$ ). 
In Chilcotin mythology three brothers try to trick their grandmother; she transforms them into stars; their dogs and the moose they were tracking may be seen with them in the sky (MAM $4: 31$ ).

\section{Muskrat Trespasses}

Muskrat disobeys his grandmother by going in a forbidden direction

Otter clubs Muskrat

Muskrat's grandmother treats him

Muskrat kills Otter's sister, Mink

Otter comes for revenge

Muskrat feigns sickness and Otter leaves believing him to be bedridden

Muskrat's grandmother sings song of triumph

Otter pursues Muskrat and his grandmother

Muskrat and his grandmother escape

Muskrat and his grandmother lived together. One day the grandmother saw Muskrat was trespassing when he went for food. The next morning she said to him, "When you eat grass go this way (pointing). Don't go over the way you have been eating." Every morning she warned him this way. One day he thought, "I wonder why she always keeps at me this way. I wonder what is over the other way."

$\mathrm{He}$ went the forbidden way and found much grass. "The grass is so good here, I guess that is why she forbade me going this way." Soon he met an Otter. "I drive people out of here." "It isn't your land." "It isn't yours either." They argued and Otter clubbed Muskrat until his head was all flat. Then he threw him into a canoe.

When Muskrat's grandmother came back he was gone. She thought, "He must have been trespassing again." Then she heard him coming, $\ddot{a} n \ddot{a}$ ’ $\ddot{a} n \ddot{a}$ ' $\ddot{a} n \ddot{a}$. She saw a canoe coming. He was lying down in it and paddling. He came in. His head was so swollen that his eyes and ears could hardly be seen. His cheeks were all puffed up. His grandmother said, "I told you not to go that way. It's your own fault you got beaten up so badly."

He lay down and she sprinkled his head. A few days later he was well and said to his grandmother, "Get my canoe ready. I am going to kill Otter." "No, you might get killed. Then I would be all alone."

She coaxed him in vain. He got into his canoe and paddled to Otter's house. There were four of them. He saw their sister who was Mink making a hole near the water to make herself a bathing place. When she had the hole made just big enough to sit in she put hot stones in the water. She had leaned her baby in its babyboard up against a tree. Muskrat sneaked up and shot Otter's sister just as she was going to get into her bath. She fell headfirst into the water and died. Then Muskrat rowed 
home as fast as he could go. His grandmother was waiting for him. As soon as he came in sight she exclaimed, "Oh! Thanks be! He is alive."

"I killed Otter's sister," he told her. "There's no hope for us now," said the grandmother. Then Muskrat said, "Make a hole through the bushes like a tunnel beginning where you are sitting. Then go through there and you will see a lake." The old woman did so. Then she came back. "Tie up my head and keep sprinkling it for me," he ordered next.

The Otter brothers kept looking for their sister to return with her child. They heard the baby cry. Then said one, "Why doesn't she look after her child? Go tell her to take it up." One went to see what was the matter. He found her dead. He reported to his brothers, "She's dead, shot with an arrow." They went and looked. "Muskrat must have done that," they said. The youngest said, "I am going to kill him."

He came to Muskrat's house. The grandmother was watching. "Here they come. Let's get ready." When the Otter arrived the grandmother was sitting there quietly sprinkling Muskrat's head. He was lying near with his head all tied up. Otter came in with a stick. "You must be the one who killed our sister." "Why how could that be?" said the grandmother. "He is pathetic. He always lies there just like that." "Who could it have been then ?" "Oh, sprinkle my head, grandmother," moaned Muskrat. Otter thought, "It must be true. He never gets up." He left. Then Muskrat said, "Keep watching him until just as he rounds the curve, then dance and sing."

The grandmother watched. Just as Otter got out of sight she began to sing and dance, "Uhu $u h u \cdot$, Otters' only sister was killed by a little arrow. She fell headfirst into the water." Otter kept on thinking, "Who could have killed our sister?"

He rowed back again. He heard the song more clearly. He saw the grandmother run into the house. She ran into the hole she had made and covered it over. He could not find her. He looked around outside. Then he went in, lifted the cover and saw the hole. He reached down into it, but the muskrats had filled it with dirt as they went through. Otter followed as far as the timber but he had to give up as the hole became too small for him.

The end of the road.

In Shuswap and Coast Salish mythology are found examples of myths which are on the whole comparable, though they vary in specific details:

In the Shuswap myth Muskrat kills a girl who refuses to marry him; Muskrat sings a song revealing himself as the killer; the people pursue Muskrat who escapes through a hole in the ice (MAM $4: 680$ ). 
In the Coast Salish story it is Wren who kills Otter. The motivation lies not in a trespassing incident but in Otter's theft of Wren's fish. When the people discover Wren to be the killer, he is invited to a gathering. In the Upper Chehalis version Wren escapes, Bluejay catching Snail by mistake (MAFLS $27: 31$ ). In the Humptulip account Wren is kicked into the fire; his grandmother blows on his cinders and he becomes a wren; she turns into a spider (MAFLS $27: 326$ ).

\section{Toad Saves Children}

Lazy daughter of chief, her baby brother and all the village children are deserted The children stay in the house of a child-eater

Toad keeps girl from rising

Toad takes girl's place in monster's oven

Girl runs away

There was a chief of a village who had a grown daughter and a son who was merely a baby. Every morning the girl carried the little boy away from the settlement and took all the other little children with her. All day she played with them and brought them back at night. For some time she did this. One morning when the chief saw her persist in leaving home with the little ones instead of learning to work like the women, he felt sad. So he decided to punish her.

After she had gone he called his people together for a council and said, "We will leave the children." They pulled out all their tipi poles and all the people went into the holes. ${ }^{1}$ At night the children came back. Everything was gone. There were no people. No fire. They cried. The girl told them all to come into one house to sleep. The next day she said, "We'll go look for our parents." All day they travelled. At night they saw a camp. The girl said, "Let's camp there."

Someone came out and saw them. They were glad. "We want to camp here," said the girl. "All right!"

The children went in. The owner of the house was glad to see them. They sat around but were given nothing to eat. The owner of the house had some children already lying there asleep. All went to sleep except the chief's daughter. "Go to sleep," he said. "No," she answered. "Put down your little brother." "No, he might cry."

The owner lay down. After dark the chief's daughter heard someone get up. Xuts xuts xuts, she heard a bone breaking. She kicked the fire to make it lighter and heard him go out. This kept up all night. She thought, "He devours a lot of people."

In the morning he said, "Come, let's bake them." He made a pit in the ground for baking. He said to the girl, "Go get the leaves for the

${ }^{1}$ They were some kind of animal. 
baking. Give me your brother, I will hold him." "No, he might cry." She went. She cried, "I will be killed and my brother too."

She pulled out a lot of leaves and grass and made a big stack which she then tied. She had to put her brother down in order to get the pack on her back. When she tried she could not get up. When she did get up she saw there was a Toad in the grass. She laughed, "Ha ha, you are going to die. Your brother will have to die too. Every time you see an animal, step on his back, don't step on the ground. I am Toad. I am ugly, you are young and beautiful. I will die in your stead."

She loaded the grass, her brother and Toad on her back and returned to where the fire was being made. The children were lying there. She put down the grass, but kept her brother on her back. The monster fixed up the pit, put the children in and arranged grass over them. Then he put soil on top and baked them. In about an hour he thought they ought to be cooked. He took the oven apart and came to the children. They had not begun to cook. He piled them on one side and came to Toad. She was still alive. "It's your fault. You are the one who caused the fire not to bake.",

The girl ran away. She stepped on the backs of the animals she met and never on the ground. Finally she came to a mountain where she stepped on the ground. From there she stepped on another mountain. She went far this way.

The end of my road.

In the mythology studied no parallels were found for the Coeur d'Alene Toad Saviour episode. There are typical examples of the desertion of a girl and her young brother and their capture by a child-eater in Sahaptin and Nez Percé mythology.

A mother and father desert their daughter and small son who have refused to fetch water; the children are captured by Screech Owl (Owl Monster) and put in her basket; Screech Owl hangs up her basket and rushes home when the children shout that her family is burning; the children cross the river on their grandfather's leg; their grandfather has Crawfish, Mussel and Butterfly (and Bullhead and Swallow) drown Screech Owl who comes in pursuit (MAFLS 11:176, 192).

The element of the captive placed over the fire to cook who urinates and extinguishes the blaze may also be found in otherwise dissimilar myths as, for example, among the Thompson and the Shuswap:

The man-eaters place their victims (the wives of Eagle and Owl and their two children, a boy and a frog; Coyote's two daughters and their son; a mother and

${ }^{1}$ Toad spoiled the fire by making everything wet (cp. tale 1 ). 
her boy) in a kettle over the fire to cook overnight; the child (the frog) urinates through a hole in the kettle and saves them from boiling; they escape (MAM $12: 253$; MAFLS 6:35; MAM 4:636).

\section{Chipmunk and Snake (Contest for Winter and Spring)}

Chipmunk pokes fire to bring spring

Snake pokes fire to delay it

Chipmunk goes out and nibbles grass

Snake smells fresh grass and sees spring has come

Chipmunk and Snake lived together. Their fire was one long burning log. Each of them had a stick with which to poke the fire. Chipmunk poked the fire, $u$ ya ha ya ha. ${ }^{1}$ Snake poked it. "Winter" was the noise he made. When the $\log$ was burned through the middle it would be spring. Chipmunk was hurrying it to make spring come quicker, Snake was trying to delay it because he wanted winter. The only time they ceased arguing was when they slept. At dawn as soon as they woke they took up the stick. Suddenly the Chipmunk said, "I'll go outside and see."

She went out the door. Already the ground was clear of snow. Small blades of grass showed through. She nibbled it. She went in again and took up her stick to poke the fire. Snake asked, "Is it clear yet?" "No, there it still snow on the ground." Then Snake repeated, "Winter!" Suddenly she said, "You smell of green grass." "No, it's the mat you smell. I just turned it over."

Outside all was green. "tsatapi'yap" spoke Snake. "Ya ha," said Chipmunk. Patsatsa, Chipmunk ran out. Snake said, "My! She does smell of green grass."

Then he went out. The ground was clear. The sun was shining. Snake ate grass and curled himself up on the ground.

The end of my road.

In a Thompson myth Grizzly Bear and Chipmunk dispute about light and dark, warmth and cold in general, with no specific reference to the seasons.

A $\log$ is burning on a mountain (perhaps kindled by Coyote's youngest son to give the people fire) ; Grizzly Bear dislikes warmth and light and throws earth on the fire; Chipmunk throws sticks on the fire; and fire burns more brightly; Grizzly pursues Chipmunk who escapes into a $\log$ as Grizzly tears the skin off his back leaving stripes (MAFLS 6:61).

In Coast Salish mythology are found typical versions of the numerous

${ }^{1}$ This is said for the word which means "calm weather." 
contests for day and night in which Bear figures as the proponent of long periods of darkness. Neither Chipmunk nor Snake appear:

Ant wins a race with Bear and obtains thereby short successive nights and days (Upper Chehalis MAFLS $27: 132$ ). Bear, who desires night for six months (a year), competes with Ant and Yellowjacket; Bear is beaten; as a result Bear now sleeps three months at a time (Upper Chehalis MAFLS 27:132; Cowlitz MAFLS $27: 188$ ). Bear, who wants to sleep five years, compromises with Frog to sleep one year (winter) ; Frog is also to sleep one year, people one night (Cowlitz MAFLS $27: 189)$.

\section{Elk and Snowshoes}

Snowshoes and Elk live together

Elk rebels at doing all the work and leaves

Snowshoes pursues Elk and kills him

Snowshoes and Elk were friends who lived together. Snowshoes hung on the wall. He never made fire, got water or wood, neither did he cook. Elk did all the work. One day he got tired. He thought, "I do all the work, my partner never does anything. I am going to leave."

He went away. The snow was deep. He threw away his ax and his rope. The fire went out and Snowshoes got cold. He tracked Elk. He found his ax and his rope. He saw where Elk had started to run. "I am deserted. I'll kill him because he left me."

He followed Elk. He came to a mountain. About halfway up he shouted. He thought Elk would look back, but he went right on. He was always a long way ahead. Finally he began to catch up. Elk could hear Snowshoes, up'axp'axp'ax, in the snow. Elk noticed he sank in deep. Snowshoes was catching up.

"You are going to die," he cried out. "No, don't kill me, have pity on my face," said Elk. "You left me." So saying, Snowshoes took out his arrow, shot him and he died.

The end of the road.

No parallels to the brief Coeur d'Alene story were found. A certain stylistic resemblance to Snowshoe's laziness and consequent desertion may be noticed in a Tlingit story, a typical episode in the Raven cycle. The idling in this case is well in accord with trickster Raven's character:

Raven goes to stay with Fishhawk; Fishhawk rebels at doing all the work and food-gathering for Raven, as well as for himself, and leaves (BBAE .39:116). 


\section{Contest between Cold and Heat}

Cold and Heat who cannot get along together have a contest Heat overcomes his younger brother, Cold

Cold and Heat were brothers. They had their house across the river. Cold was the younger. When he went out there would be frost on his eyebrows and ice on his beard. He would come into the house and complain as he sat in a corner farthest from the fire, "Why do you keep it so warm? I'm very uncomfortable because of your big fire."

He left again in the morning. Then Heat went out and looked at the sky. It was dark and threatening. He looked down at the ground and saw a snowbird crawling about on the snow. Cold came back while he was out and said, "My, he keeps it hot! I suppose he'll be making the world all warm again, my brother who is gone."

Just at sunset a hot wind blew. Cold sat in his corner and sweated. Then Heat blew into the house. "You keep it much too warm," said his younger brother. "I do not wish to kill everyone. I have pity on the people who travel." Cold said, "Here I am all wet with sweating."

So that is the way Heat overcame his younger brother, Cold. That is all I know.

This sketchy Coeur d'Alene version has probably fallen out of its setting and lost some of its descriptive parts. Analogous Thompson, Sahaptin, Sanpoil, Okanagon and Upper Chehalis. myths, concerned with the overpowering of Cold, are adequately motivated and recorded more fully:

Heat Man takes his wife, Cold Man's daughter, to his family for a visit; Cold Man pursues the two; Heat Man's father draws out the Chinook Wind, the air becomes warm, Cold is beaten; Heat allows Cold to visit his daughter once a year for a short time; then it is winter (Thompson MAFLS 11:61).

Two brothers leave the house of Winter's father and go to the home of Summer and his five daughters, whom they prefer; Winter's father, accompanied by Winter, decides to wage war on Summer; Summer by shaking his blanket at their approach melts all the ice from their bodies; he sends them home with meat (Sahaptin MAFLS $11: 148$ ).

The necessity of overcoming extreme cold which is killing all the people motivates the Sanpoil contest between Cold and Heat:

South Wind is chosen by the people in the Indian country to overcome Extreme Cold; South Wind goes to Cold's house, makes a fire, thaws everything and the Cold family dies; the seasons are henceforth regulated (MAFLS 11:105). 


\section{In the Okanagon myth Coyote conquers Cold :}

With the help of his three pieces of dung, one of which is equivalent to the heat of the sun, Coyote enters the Cold people's house, burns it and melts the ice; Cold and his wife die; Cold's daughter escapes; there shall be cold once in a while (MAFLS $11: 74$ ).

In the allied myth of the Upper Chehalis Northeast Wind represents the Cold and Southwest Wind the Heat:

Southwest Wind, who has his home in the ocean, makes war upon Northeast Wind in the sky; Southwest Wind's party returns home without fatalities. In a second fight Southwest Wind fails to overpower the seven Northeast Wind brothers with boiling water; thereupon his grandmother makes a water-sprinkler for him; five of the Northeast Wind brothers are killed. Southwest Wind melts snow and frost so they no longer freeze people to death (MAFLS $27: 75$ ).

Detailed instances of a struggle between the winds, which follow an outline similar to those laid out above, may be found among the Tsimshian, Tlingit, Haida, Thompson, Shuswap and Lillooet (ARBAE 31: 732).

\section{Rabbit and Jack Rabbit}

Jack Rabbit worries about Rabbit, his relative and friend Rabbit worries about Jack Rabbit, his relative and friend Rabbit takes pitch to Jack Rabbit Jack Rabbit takes bitterroot, camas and dried salmon roe to Rabbit They meet on Tekoa Mountain

They leave their unnecessary gifts there

Rabbit and Jack Rabbit were relative-friends (cp. p ). Rabbit lived in the mountains around here (near De Smet) and Jack Rabbit lived on the prairie of the Big Bend country. In winter when it cleared after a snow Jack Rabbit would look toward the mountains. The trees were so heavy with snow that the branches interlocked. Jack Rabbit worried, "I think Rabbit must be dead. I wonder what he eats."

Rabbit looked toward the prairie. He thought, "Poor Jack Rabbit! I wonder if he has a fire in this cold weather. I'll go see." He made as large a pack as he could carry of pitch shavings and started off with it toward Jack Rabbit's. Then Jack Rabbit thought, "I think I'll take my relative-friend some bitterroot, camas and dried salmon roe," and he started off with them.

Rabbit came up the north side of Tekoa Mountain. As he came up he 
sat down at the edge of the woods. He thought, "I wonder where Jack Rabbit lives. I don't know exactly."

Jack Rabbit came over the prairie and up the south side of the mountain. As he went over the top he saw Rabbit sitting there, "Why, here he is!" He stood up. Jack Rabbit looked up and saw him standing there. They walked toward each other and shook hands.

"You're still alive, my relative-friend!" said one. "And you're still alive, my relative-friend," said the other, "I was just coming to look for you." "Why," said Jack Rabbit, "I was coming to look for you too. I was worried about you. I thought you might be hungry."

"No," said Rabbit, "I am not hungry. I find a tree under which there is green grass and I eat that. It's you I worry about. I thought you might get cold so I brought these pitch shavings for you to start a fire." "No, I'm not cold. You worry for no reason. When it snows and drifts I find a dry spot under the sage brush. That's where I stay."

"Then I'll throw away the pitch." So saying Rabbit untied his pack and dumped it out. Jack Rabbit said, "I'll dump what I brought to feed you."

He dumped it out and each went his way. That is why all the trees on Tekoa Mountain have pitch on them. That is why bitterroot and camas are found there. ${ }^{1}$

The only parallel found for this myth, the Nez Percé story of Cottontail Boy and Snowshoe Rabbit is identical with it in all but minor details.

Cottontail Boy worries about his friend Snowshoe Rabbit in the cold; Snowshoe Rabbit worries about his friend, Cottontail Boy, in warm regions; they meet, each anxious to inquire about the other's health; they part to meet again some time (CUCA 25:3).

\section{Dog Goes for Fire}

Wolf asks Dog to steal a spark of fire Dog, forgetting Wolf, stays with people

People had a fire. Wolf had no fire. Wolf and Dog were friends. Wolf said to Dog, "Go steal a spark from the people."

Dog went to the people. They fed him and he forgot to steal the spark. That's all.

The short Coeur d'Alene story is typical of the variants of this myth

${ }^{1}$ These plants are now extinct, but were found on Tekoa Mountain until recently. 
which occur in other bodies of mythology in a consistently brief form. The Cowlitz, Humptulip, Quileute and Quinault have the story.

Wolf and Coyote send Dog for fire; Dog stays with the people who feed him; consequently Wolf and Coyote always fight Dog (Cozvlitz MAFLS 27:191).

The four Wolves give their younger brother, Dog, scraps to eat; Dog, left at home to tend the fire, neglects it; he is sent to the people for fire and stays with them; dogs can escape Wolves only by urinating in their eyes (Humptulip MAFLS $27: 307)$.

In the Quileute and Quinault versions it is within a longer myth in which the Earth People wage war upon the Sky People that the motivation for Dog's errand for fire is found. Earth People find themselves in need of fire in the cold upper regions:

In the Quileute myth Snowbird is sent to a house for fire and fails to return; Dog is dispatched, is fed by the Sky People and stays with them; Rabbit succeeds in bringing his fellow-warriors fire (CUCA 12:81).

In the Quinault myth Robin and Dog are so comfortable with the Sky People that each forgets to return with a firebrand; Dog is fed camas (MAM 4:109).

A Kathlamet myth, a composite of various elements of the preceding versions, is noted below for its comparative interest.

Beaver successfully obtains fire from the Sky People by a ruse; the Earth People then dispatch Skunk, Robin, Mouse and Rat to seek an entrance to the Sky People's house; Robin warms himself at a fire belonging to two old women and remains with them; when he returns home some time later his belly is burnt red from the blaze (BBAE $26: 68$ ).

\section{TALES WITH HISTORICAL ELEMENTS}

\section{Turtle's War Party (Mock Plea)}

Turtle assembles Water People for a war party

Watersnake refuses to take part

The party turns back; Turtle advances alone

Turtle kills a Nez Percé chief

Turtle is discovered with chief's scalp

Turtle mocks death by pounding with a rock and burning; he pleads against being drowned

Thrown into water, Turtle returns home and holds scalp dance

Turtle had a house at Chatcolet. One day he said, "Come to my place, all of you who belong in the water." 
The turtles, fishes and all the water animals came. At night Turtle took a blanket and sang: " $h i \cdots a h i \cdots a \cdot n$." All the people took hold of the blanket and began hitting it with a stick as they sang. Snake however was too proud and haughty to take part. He merely walked some distance away with his striped blanket pulled up to his nose and looked on.

In the morning Turtle said, "I'm going on a raid to the Nez Percé country."

All the Water People started off with him. They had not gone far when night came on. Turtle clubbed the blanket and sang. The next morning they went on but on the second day had gone only as far as Plummer. The second night they sang and drummed again. In the morning the chief, a big salmon, said, "We'll turn back. You know we belong in the water. My children (people) are dry."

Then Turtle said, "You can go to Spokane for all I care! I started and I am going to reach my goal. I won't turn back."

The fish all turned back. Turtle went on alone. Before night he came to Fort Lapwe, a place in the Nez Percé country at the foot of a very steep hill. On the top of the hill he sat down. He saw the people on the other side of Snake River. He waited until dark. Then he went down to the water where he crawled because it was his element. The people however did not walk but moved like fish. Turtle crawled up to the shore. There he saw many houses. He went in among the tents. There he discovered the chief's house because many people were going in and out to smoke.

After they had all come out, Turtle crawled in and hid in the space between the main house poles and the door. ${ }^{1} \mathrm{He}$ listened until the chief snored, " $x u$ xu."

Turtle took his knife and cut off the chief's head at the throat. $\mathrm{He}$ never moved or made a sound. Then Turtle took hold of his hair and cut his scalp off entirely. He pulled up the blanket over the chief and went off with the scalp under his arm. Then Turtle went to sleep. In the morning the people began to pass the chief's house on the way to the sweathouse.

His wife said, "He is still asleep." She cooked, but when the food was ready she was too kind to waken him. When the sun was very high the people came back from sweating and said, "Where is the chief ?" The woman said, "He is still sleeping." "Why is that? It is too long to sleep." "My breakfast is already cold."

He still did not stir or make a sound. Then the wife thought, "I'll look at him." She turned back the blanket, "Why, he's dead!"

${ }^{1}$ This was the place where things were often stored. 
Then all the people came. They saw he had been scalped. As they were arranging the body for burial they found Turtle with the scalp under his arm. They said, "This must be the one who killed him." They pulled and pulled at him but in vain. One said, "Throw him on his back and pound him with a rock."

Turtle then ran and cried, "Go ahead and try it! I'll kill some more of you." Meanwhile he hit himself with a rock as if he did not mind the blows. The people said, "No, that won't kill him. Let us throw him into the fire."

Turtle ran on his hind feet like a dog toward the fire crying, "That will only make me tougher so I can kill more of you." "No, that won't do. How can we kill him?" Another suggested, "Let's throw him into the water." And then Turtle covered his eyes with his hands and cried and begged, " $a$ a, don't, please don't throw me into the water!" "Go ahead! Throw him in! That's the way to kill him."

They had not been able to pull him away from the ground for he clung tight to some obstruction, but now they took a stick and he let himself be pried loose. They took him toward the water but as they came near an old man said, "Stop, don't you know that's just his element."

As soon as Turtle heard that he sprang free and jumped into the water. The people said, "He's dead. How can he come ashore again?" The old person said, "Does he not have his home in the water? There he lives from one year's end to another."

The people went to the river. From the other side they heard Turtle singing and waving the scalp "axiya xiya." They crossed the river and chased him to the top of the hill but they could not catch up with him, so they turned back.

Turtle came home to Chatcolet. He cut off the branch of a bush to which he tied the scalp. He waved it and kept on singing. The people said, "Turtle must have come back. He brought a scalp." So they had a scalp dance. ${ }^{1}$

Each one dressed himself up in his best. He painted his face red and yellow and combed his hair in a different way. He made stripes all over his body with red paint, especially under the arms. Frog and the various fishes, all painted themselves and danced and sang. Turtle kept hold of the scalp. The people danced and gave the war-whoop. Snake just stood with his striped blanket drawn up to his nose like a Nez Percé and never took part in any of the dance. ${ }^{2}$

1 The stem is said to mean "make fun of, taunt, an enemy."

- Nowadays the Nez Nercé fear the turtle much as many white people fear the mouse. A Nez Percé chief was actually mysteriously murdered and no one was ever able to find out who did it (explanation by interpreter). 
Turtle figures as the lone killer in a similar myth of the Kutenai:

Turtle goes to a strange town; he kills a chief; he is discovered with the chief's head; he mocks death inflicted by a knife, a bow or an ax; he pleads against death in the water; released in the water, he returns with the chief's head to the tent he shares with Beaver (BBAE $59: 22$ ).

An Okanagon version opens with the animals' war expedition against the sky forces for the purpose of obtaining fire; Turtle falls from the sky and kills a person (Globus 52:137). His adventures at this point follow the outline recorded for those of the Kutenai myth. In conclusion the animals return home from the sky.

In a myth of the Thompson chief Rainbow Trout replaces the Coeur d'Alene Turtle as the leader of a war party. The story is concerned however solely with the warring expedition and Chief Rainbow Trout has no individual significance beyond the fact of his leadership.

Rainbow Trout summons the fishes of the interior for a war party into the coast country; some of the party turn back, the rest continue; they wage successful wars against the coast fish and spread into the streams over the country; some return home (MAM 12:350).

Further instances of the use of the Mock Plea appear in other connections in the mythology of the Tlingit, Quinault, Chinook and Nootka:

A great swimmer's wife dies; he finds her in a hostile village in the sky; he mocks death by fire, pleads against being thrown into the water and swims away to safety; Spider Woman helps him descend from the sky with his wife (Tlingit BBAE $39: 251$ ).

Squirrel and Black Diver taunt Bluejay for killing his own child in a Bungling Host episode; Bluejay takes them captive in his canoe; the ropes binding them break continually; Black Diver suggests weeds instead; he bursts them and dives into the water; Squirrel suggests Bluejay confine him in a brush-pile; Squirrel escapes (Quinault MAM 4:91).

In the Chinook myth Bluejay is similarly tricked by the man he holds captive in his canoe, who suggests sea-grass as more effective than rope for binding him; the man, when thrown into the water, unties his bonds and escapes (BBAE 20:22).

In the Nootka story Cuttlefish begs a man not to kill him in front of his house, on the shore or in shallow water, for people would say the man's threshold was bloody; the man takes him out into deep water; Cuttlefish wraps his arms about him and drowns him (IS 109).

Bluejay's war party is the subject of a Shuswap myth. The expedition has for its goal the conquering of a water monster and thus belongs 
in quite a different category from that of Turtle's War Party. The similarity lies solely in matters of war procedure.

Bluejay dances the war-dance, sings his war song, sets out on the warpath with his brothers, kills the water monster, and dances the dance of victory (MAM $4: 665$ ).

\section{Two-Headed Snakes}

Women gathering camas encounter snakes with two heads on each end A flood reaches the snakes' hole in the cliff and destroys them

Directly north of the old church at Cataldo there is a flat where many camas grow. Women gathering camas would hear teeth knocking together, otsax tsax, and would see something coming over the grass. It was a two-headed snake which had to go flat over the grass like a scraper so as to keep its heads in place. Some of the women ran, but some were not quick enough and were struck. Some were knocked down because it was so strong.

There came a rain. Snakes' house was high in a hole in the cliff north of the camas flat. It rained so hard the flood reached the hole and killed the snakes. They were never seen after that.

When I was a little girl I used to hear of snakes with heads on both ends. ${ }^{1}$

The Coeur d'Alene narrator of the Two-Headed Snake story claimed it was a true story. The double-headed snake or serpent appears in stories of other tribes as an avowedly mythological being to which supernatural power is commonly attached.

Four myths may be noted for the Kwakiutl in which the doubleheaded serpent puts in an appearance:

A man sees a double-headed serpent and kills it (MAM 5:60); a woman finds the scales of a double-headed serpent and rubs her son's arrows with them (MAM $5: 138)$; a boy washes his hands in the slime of the double-headed serpent and becomes Stone Hand (MAM $5: 146$ ) ; a man rubs his son with the salmon, the doubleheaded serpent he has killed, and the boy becomes Stone Body (MAM $5: 197$ ).

A number of further references to the fabulous snake may be found distributed among the Lower Fraser, Squamish, Comox, Kwakiutl and Newettee tribes:

A man safely passes the double-headed snake (Lower Fraser IS 41); a boy kills the double-headed snake with a head at each end (Squamish IS 58); boys in

${ }^{1}$ Dorothy's father saw these snakes. Each was about three feet long, as thick as an arm and had two heads at each end. Their den was a hole in the cliff which could not be reached by man from the top or the bottom. 
heaven catch the double-headed snake and instruct it to eat their father-in-law, one head eating at each end (Comox IS 68); a man sees a fiery two-headed snake, hurls his spear at it and receives supernatural power for catching seals from it (Comox IS 81 ); men test their power by feeding each other a double-headed snake but they both survive the test (Krwakiutl IS 134); two transformers see the beautiful two-headed snake, one kills it and takes its skin and eyes which help him in great displays of power (Newettee IS 195). In still another Kwakiutl myth some of the beams of the hero's house are represented as being double-headed snakes; these come to life upon festive occasions and kill any evil person who enters the house (IS 166).

In the Coeur d'Alene myth there is no such supernatural adaptation of this alleged natural phenomenon.

\section{The Dwarf}

A man out hunting loses his powderhorn

A dwarf hangs it on a stump

The man's wife is injured by a dwarf at a waterhole

Once a man went hunting. He had a bandolier with a powderbox of buffalo horn. As he walked along he noticed that the box was missing. He turned back to look for it. He thought, "It must have fallen on the trail whence I came." He searched a whole day without finding it. The next day he saw it hanging on a stump. That's where a dwarf had hung it.

That same' man went hunting another time. His wife stayed home. She went to a hole in the ice for water. Far off the man heard screaming. It was the woman crying. He thought, "I wonder what is the matter." He turned back and went past his house toward the water. He saw his wife standing on the ice and there was nothing but blood around her. He said, "What is the matter?" The woman said, "A dwarf hurt me." That's all.

\section{Man Caught in a Fire Corral}

People impound animals in fire corral

Fire gets beyond control and people rush out

One man is missing

The people look for him at night

They find something in the dark and wail over it

It turns out to be a grizzly bear

The man is found alive, but badly burned

They tell about a time when the people made a fire corral near Sand Point. The grass was burned in a large circle and a small opening was 
left into which the animals were driven. Just as they were shooting the impounded animals a strong wind came up and burned the grass inside the fire corral. Those who had game ran to the entrance with it. Someone noticed that one of the men had killed something. They ran home and as soon as they got to the house where they had a council they found out that one was missing.

"I guess he must be burned," they said. They waited for him until night but he did not come back. "He must certainly be burned," they thought. His wife said, "Come with me. We'll look for him."

I don't know how many people (but many) went with her. They came to the place. "It was right here we saw him last," a man told the woman. The people scattered in every direction. "Here is where he lies dead," they reported.

They saw something black lying there in the dark. They all surrounded it and began to cry and wail. The woman sat by what she thought was the head and the rest sat around the dark thing. Then she thought, "I'll feel it." She felt its face but it did not seem like a person. She felt further back and cried, "He has long ears. It's very different from a man."

They all felt and found it was a bear. Then they laughed. They got up and searched again. They finally found another dark figure lying there. It was the man. He was still breathing, although he was badly burned. "I guess the bear was his catch," they thought. They took him back to his house.

Thus it is at the end of the trail.

\section{Flathead Chief Sends his Daughter to Chief Waxane'}

Flathead Chief sends his daughter to Waxane', Coeur d'Alene chief Leader of Ugly People pretends to be Waxane', marries girl

Girl consults real Waxane"s daughter

Waxane' has false chief and all Ugly People killed

Waxane' pays damages to false Waxane"s children

One of the Flathead chiefs had a daughter. He said to her. "There is a famous Coeur d'Alene. Go to him and stay. ${ }^{1} \mathrm{I}$ am not sure of the road but you climb a high mountain. When you get on top you will see a river flowing toward the Nez Percé country, one toward the Blackfoot, one toward the Kalispelm country and one directly toward the place where the sun sets. That is the way you should go."

The girl went. She climbed the mountain. She saw the water flowing toward the west. She came to the big stream. Suddenly she saw a person

${ }^{1}$ The implication is that he would take her for a wife. 
coming toward her on the water. She went toward him and sat down on the bank. He rowed up to her. "Oh, you're here," he said. "Yes." "Why are you wandering around this way?" "Yes, my father said to me, "Go to Chief Waxane'.' Am I going toward his place?" "Why yes, I am the one you were sent to. Come, get into my canoe."

He paddled on. She went with him to his home. "What has happened ?" he was asked. "You bring a girl back as your partner?" "Yes, her father told her to come to me, so she came."

She stayed there for a time. The man had many brothers. These people were called Ugly People. They lived apart from the rest of the people. When the girl became better acquainted she thought, "I don't believe this is Waxane'." She found out that the man who really had that name had a little girl. She watched for her. She saw her come and said, "Come, come!" Then she questioned her, "Who is your father?" She answered, "His name is Chief Waxane'." "Why! He's the man I was sent to."

The little girl went home and told her father about the woman and the directions which had been given her. He said, "Ah !" Then he went to the girl and asked, "Am I the one you were sent to?" She said, "My father sent me to Chief Waxane'. A man saw me and said, 'I am the one,' so I went with him." "The next time they go hunting say, 'I am sick. I have a headache. When it is better I'll go with you.' "She said, "All right!"

In a few days they said the people were going hunting. She said, "I have a headache." They went. The mother and father were the last to go. Just at sunset the real Waxane' said to his people, "Go, kill that man."

They tracked him and killed him between St. Mary's and Wallace. After they had passed this place the chief said, "Go, find the rest and kill them."

There was an old man. He was made to come along. At night he was told, "Go in, if you are quiet all the people will say to you, "Now tell stories." " He did as he was told. From a distance he saw a house. $\mathrm{He}$ went in. The people said to him, "You could come up to the fire." It was cold. He said, "I am cold. What you have left, just the scraps, I'll eat. That's why I came."

He began to tell stories. They said, "Stop now, we are sleepy." But no! He kept right on. When they snored he went back to his partners, "They're all asleep."

The youngest and oldest went in and killed all the people. ${ }^{1}$

${ }^{1}$ The Ugly People lived at a place called Hinma'tsap. 
"Go back to Waxane'." Three men went.

The chief had said, "Don't kill the children, but just their parents for they are your sister's sons. If he shoots at you say, 'Stop, my mother's brothers." "

They all went. The father was killed. They said to the children, "Your mother's brother said, 'Go kill your father, but do not kill the children." "They came back and reported, "We didn't kill them." After some days they came back crying.

The chief said, "Bring all the things you can, clothes, moccasins, pants, blankets. The children have arrived."

The chief called them in. He said, "Because your parents were wicked they were killed. You must not be that way, you must be good. Well, here are the damages." That's all.

The end of the trail.

Other tribes have myths in which similar instances of mistaken identity occur but, beyond this stylistic resemblance to the Coeur d'Alene factual narrative, the myths are distinct.

A Kathlamet myth of this class calls to mind perhaps more readily the introductory episodes of the Coeur d'Alene Skunk and Fisher story (tale 23).

Bluejay sends a maiden to chief Panther; Beaver deceives the girl about his identity and she stays with him; Panther fetches her; Beaver causes a flood (BBAE $26: 20$ ).

In Tsimshian mythology a princess mistakes the Prince from Heaven's slave for the prince and marries him; the prince marries the princess' lame sister, whom he cures; the prince and his wife transform the slave and princess into fish (ARBAE $31: 298)$.

In a Kwakiutl myth Prince Property Body tells his sweetheart, Calling Tribes, he will not be able to come to her one night; that evening Calling Tribes mistakes a stranger, Chief of the Wood Men, for Property Body; Wood Man takes Calling Tribes to the ghosts' country; Calling Tribes partakes of the ghosts' food and is doomed to remain with them (MAM $5: 250$ ).

In a Thompson myth Crow, a slave, leads his mistress to believe he is a wealthy stranger; he has connection with her and flies away; she pronounces him henceforth a crow (MAM 12:236).

The incidental element of the Coeur d'Alene tale, telling stories in order to put the enemy to sleep, is made use of by many other tribes, for example, by the Kwakiutl, Nootka, Haida and Tlingit. 
Deer effects his escape from his captors, the Wolves, by putting them to sleep with a story (Kwakiutl CUCA $2: 163 ;$ Nootka IS 110). Chief Wisest One put Cannibal at North End of World, his wife and child, to sleep with a story, so that he and his children can kill them; the cannibals' ashes become horseflies and mosquitoes (Kwakiutl CUCA 2:39). Raven puts Chief Eagle to sleep with a long story (of his origin and the world's history), so that he can steal the water of which Eagle is keeper; springs and rivers flow where water drips from Raven's mouth (Eagle smokes Raven black when the latter flees as a crow, dripping water upon the earth) (Haida MAM 8:235; Tlingit JAFL $20: 294$ ).

\section{The Coeur d'Alene Attacked}

Three boys are instructed to seek vision

One of the boys sees woman in bright light who warns him of enemy

Boy refuses to leave camp

Enemy attacks, other two boys killed

Boy and mother run away

$\mathrm{He}$ returns for new suit

$\mathrm{He}$ and mother escape, return to stunned father

Clean Face faces enemy alone

Clean Face's daughter shot in back

Boy's uncle's horses stolen by enemy

Uncle heads off enemy

Shoots enemy riding lead horse

Party returns home with horses

Long ago before the white man had come a boy lived near the place which is now the old Mission at Cataldo. In those days children were obedient to their parents. It was the custom for the boys to make a onenight camp in order to make them smart (successful). If a boy slept at a one-night camp perhaps he would dream that an animal talked with him. It might be a woodpecker. He would tell the boy how he ought to act. When he got back the seeker of the vision would wear a token of his encounter with the guardian. It might be a bear's claw or a feather. Such an experience would make a boy successful.

Near Cataldo three families lived, each had a young boy. Their fathers said to them, "It is time for you to make your one-night camp." One who was tall was told to go to one place. A small one was sent to Little Plummer. The father said to the boy of my story, "Make your fire a little distance from the small boy."

They were to go at sundown so the parents could see plainly when and where they built their fires. After they had been instructed the boys were very happy. They jumped about and challenged each other to a 
hoop-game, saying, "The one who gets into those willow bushes first wins." They ran off.

Just as the boy of my story entered the brush he saw a very bright light. He was terribly afraid. He tried to step back but it was as if his body was dead. He could not move. In the light he saw a beautiful woman the like of which he had never seen. She spoke to him, "When your father calls and says, 'Go!' do not go, for the enemy is where he wants you to go." Then she disappeared.

In those days they called the enemy Chop Faces. After the woman had gone the boy could move again. He stepped back and ran home. When he went into the house he sat still and said not a word. He sat apart and watched the other children playing but did not join them. He thought, "When my father calls I won't go. If I do, I'll only pretend. I will really go to my father's brother because he lives near where father told me to go. But then, if my father finds out I have deceived him he will surely kill me. Or, if I crouch nearby I'll become a stone because father says children who are stubborn and disobedient become stones."

Finally he made up his mind, "I won't go." He sat there grieving within his heart. As the sun went down the small boy was told by his father, "Go, it's time now!" The tall one was directed, "It's time to go to make the one-night camp."

Finally the father of the boy of my story said, "It's time to go now," but the boy paid no attention. A second time he was reminded, "It's time. Didn't I say before, 'The little one is obedient." "Then the boy looked at his father's father who was quietly laughing. The father took a bucket and threw it hard at his son saying, "Get me some water! I am thirsty."

The boy was glad to have something to do and ran out with the bucket. In no time he had filled it and soon set it down by his father. Then his grandfather said to his father, "Don't say any more to him. He must have some reason for not going. You know yourself he never says 'No' at other times."' So the father did not repeat his orders to his son.

Just as it became dark the elders looked for the fires. They could see at a distance the small boy sitting behind his fire which reddened his face. Soon he was killed by the enemy who had been there filing down rocks all day for bullets. Long after this the people used to see the place where the boys had camped.

Just at daybreak the enemy moved on to Cataldo. They surrounded

${ }^{1}$ That is, he is not usually disobedient. 
the houses and shot at random. As soon as the head of the house fell the boy was wakened by his mother, "Wake up, already the enemy have surrounded us. Your father has been killed." Out of a sound sleep the boy jumped up. His mother said, "Hurry! Let us run! Follow me!"

They ran. When they were not far from the house the boy remembered the little suit which his mother had made for him to wear after he had made his one-night camp. He ran back and got it from under his pillow. He saw his father lying face down. Just as he ran off he was shot at. He pretended to fall, got up and ran on again. He ran to the water where his mother was waiting in a canoe. They paddled off and hid until the enemy went away. Then they returned to their home. The father was alive. He had not been killed but was only stunned. He said to his son, "Why didn't you tell us why you did not want to make your one-night camp?" "You wouldn't have believed me," he answered.

When the enemy left Cataldo they went toward the house of Clean Face. All alone he faced them. They shot at him and he returned their shots. He killed one and ran at them growling like a grizzly bear, hi $\cdots$. The enemy answered hi $\cdot \cdots$ and Clean Face said, "Why don't you stay home where you belong?"1

Finally the enemy surrounded him. Only then they discovered that he was alone. One of them shouted, "Catch him! He's alone!" (This was spoken in bad Kalispelm.) Clean Face answered, "All right!" Go ahead, catch me! I'm all alone!"

Just about that time Clean Face's daughter was shot. The arrow was sticking in her back. She took up a handful of dust and threw it on the wound. Someone said, "Why do you do that? Don't you know the thunder always brings dust with him?"2 The dust however brought no harm and her wound healed quickly.

The paternal uncle of the boy of my story lived with his mother east of Little Plummer. They had many horses. His mother had heard them whinnying, "The horses are talking. Go and see what is wrong." Her son did not pay any attention to her. Soon she said again, "Go, see what is the matter." "No, I suppose it is that leader of the herd, the one with the red on his back. He's probably fighting with the others."

Some time after she told him again. He went then but the horses were gone. He came back to his mother. "The horses are gone. Maybe they were driven off by the enemy." Then he reported to his neighbors, "My horses have been driven off."

They hired runners to go in every direction. They got ready and assembled. They followed the enemy. The boy's uncle headed off the

${ }^{1}$ It sounds "meaner" than this in Coeur d'Alene (Julia).

'This means using the dust would bring bad luck. 
enemy by going ahead as far as the river. There he climbed a tree and waited. He aimed his gun at the spot where they were coming. Soon he heard the tramp of horses and it was not long before they came in sight. Red on Back, the leader, was being ridden by the enemy. He went down to the river to drink. Just as he was drinking the boy's uncle pulled the trigger. The enemy fell off the horse. The rest were so frightened they scattered in every direction. The horse turned back home followed by all the other horses.

The boy's uncle came down from the tree. He had not gone far when he met his fellow tribesmen. "I shot and killed one of the enemy. I saw him fall off the horse. Then I hurried back."

They headed the horses so they would run homeward. Then the people said, "Let's go see." They went to the water but the enemy was gone. They could see where he had fallen. They said, "He must have been stunned. That's why he fell off. Well, let's turn back." They went. As they came out of the woods on to the prairie they saw Red on Back way over on the side towards home.

This war narrative of the Coeur d'Alene is the only reference to the custom of seeking a vision. This religious custom also makes its way into Thompson mythology. Moreover the vision of the beautiful woman seen in the bright light, which shows white influence, is featured again in a Ten'a myth.

A boy goes out alone to seek supernatural power in a dream; he plants a stake to show his father where he has been; he closes up a lake so that whales no longer emerge there (Thompson MAM 12:269).

A chief out hunting enters a beautiful house where a supernatural woman of great beauty is revealed to him in a sudden burst of light; in a great illumination he sees the woman's mother; he becomes purified (he marries the woman, visits his home with his wife and disobeys her; she returns to her invisible house; he finally recovers her there) (Ten'a PAES 6:51).

In a Krvakiutl myth Scab Boy sees a "brightness" at the place to which the Ducks are conducting him (CUCA $2: 67$ ).

\section{Two Women Overcome Nez Percé Man}

Two old women camping near Nez Percé country cook

One sees enemy peeping through door

Women pretend to fight, moving toward door

One throws hot mush in enemy's face and kills him 
Two very old women went camping toward the Nez Percé country. They made a camp and cooked a gruel of roots. Just as it began to boil one of the women suddenly looked toward the doorway. She saw one of the enemy peeping in. "Don't look toward the door," she said to her friend. "We are being observed. Let us get angry at each other."

The other woman said in Nez Percé, "You're ugly!" "It is not true!" They stood up to fight, one of them with the pot of boiling mush under her arm. The enemy was on his hands and knees and had his mouth open. As the women, fighting each other, came close to the door, one threw the hot mush in the man's face. He ran, but afterwards they found him dead not far from the door.

\section{Woman Saved by Loose Saddle Cinch}

Women camp out during the serviceberry season

Girl dreams of enemy

Women attacked, one is captured and one killed

Captive's husband shot in leg

Coeur d'Alene man attacks like grizzly bear

Enemy escapes with woman

Woman escapes when saddle cinch becomes loose

Squirrel instructs her to hide under $\log$

Enemy leaves and woman returns home

Long ago, many years before the white man came, the Coeur d'Alene had small settlements. About three families lived in each place. The people were always on the lookout for attacks by the enemy. The enemy would hide behind bushes and attack unexpectedly. One time the Kalispelm surprised a group of people. It was the serviceberry season. Many women had gone to camp near Cataldo. Not far from there was a good serviceberry flat.

One night a girl dreamed that the enemy took them by surprise. In the morning she said to her mother, "I dreamed we were attacked. Let us go back." Her mother said, "No, I found berries over there and tomorrow we will go." The next day they all went to pick. The girl said to her mother, "You pick there. I will pick from the opposite side of the same bush.",

Just as they were picking the enemy came galloping toward them. They ran and crawled into the long grass and all escaped but one woman. The enemy took the woman captive and said to her, "Where are your house and the horses?"

She pointed in the opposite direction thinking the enemy would travel far and thus tire. They rode over logs and stumps in the woods and 
finally came out onto a prairie. Here a woman was digging camas. The enemy touched her with an arrow. She turned to defend herself with her digging stick. The enemy hit her over the head and she died. Then they went to the house of the woman they had captured. The few Coeur d'Alene there shot at the enemy. One of them ran to get his wife. They shot him so he fell and broke his leg.

Another Coeur d'Alene man growled and attacked like a grizzly bear so that the enemy turned and ran back to their own country taking the woman with them. As they were riding the cinch of the horse on which she and her captor were riding came loose. The enemy got down to tighten the cinch. The woman thought, "I will run." She got down and ran. Not far distant was a fallen balsam fir whose leaves had not yet dropped off. As she hid there she was touched by a squirrel who said to her, "Go under the log and stay until he is gone. Then you can go back home again."

She hid there. She heard horse's hooves coming toward her, passing by very near her, then going on. Then the sound died away. Until dark she lay there. Then she came out and went home. When the people saw her they were very glad. Her hair had been smeared with red paint. Someone said to her, "Who combed you like that?" She said, "The enemy." They told her, "Your husband had his leg broken." She was sorry, but she was glad she had escaped and that her husband had been saved even though he had a broken leg.

\section{The Coeur d'Alene Fight the Kutenai}

Two Coeur d'Alene meet two Kutenai

Coeur d'Alene request shirt exchange

As Kutenai draws off shirt, Coeur d'Alene stabs him

Coeur d'Alene kill Kutenai

Two Coeur d'Alene brothers climbed a mountain. As they came over the top they saw two Kutenai coming up the other side. The Coeur d'Alene said, "Let's kill them !" The younger said, "All right!"

As they came up to the Kutenai the Coeur d'Alene said, "Let's exchange our shirts." The Kutenai objected because they said they would not look like their kind but the Coeur d'Alene prevailed. "You Kutenai, take yours off first."

The Coeur d'Alene had hold of the handle of his knife. As the Kutenai pulled his shirt over his head the Coeur d'Alene stabbed him. He growled and said to his younger brother, "Hurry! Run after him." The other straightened up and threw off his shirt. They fought. The Kutenai 
looked at his younger brother. Already he had been overcome. The Coeur d'Alene killed both of the Kutenai.

\section{Boy Takes Food}

Boy takes meat from main supply

Parents become angry; boy leaves

Goes with man to Kalispelm country

Kalispelm boy, told not to eat bear guts, runs away from home

Coeur d'Alene pair kill boy's parents, helpless because they are surfeited with bear grease

A Coeur d'Alene family consisting of father, mother and a boy about fifteen went to visit another tribe. The boy became surfeited with serviceberries and was hungry for meat. Unknown to his mother he cut a slice of meat from where it hung and ate it. His mother and father were angry and scolded him. Then the boy became angry and left. He went downstream. He came to a house where a man was thrumming the string of a bow one end of which he held in his mouth. "Opam pam," it said, as a sign the man was going on a long trip.

The boy said to the owner of the dwelling, "I'm going with you." "No, your father might become angry." "No, I am the one who is angry. My parents think more of their food than of me."

The boy went with the man toward Wallace, along the river to the Kalispelm country. They had the canoe all ready. When it was still a little light just before sunset they came where the current was swift. They were seen by an enemy boy of about the same age who reported, "My! I think I saw a person. No, it is a goose. No, it's a person."

Then it was dark. The Kalispelm family, which consisted of parents and the young boy, had a bear which they had just killed. They were surfeited with bear grease. The boy was told, "Don't eat the bear guts."1 So he ran far away from the house to sleep. The Coeur d'Alene canoe overtook the parents of the Kalispelm boy as they slept hard because of their heavy meal and killed them.

The end.

Children, taking food without permission, reprimanded by their parents and leaving home is a common theme found among the Nass, Krakiutl, Yookilta, Nootka, Tsimshian, Bella Coola and Tlingit. Each of these myths reveals a more closely knit form than the Coeur d'Alene story and the conclusions arrived at are accordingly more definite and

\footnotetext{
${ }^{1}$ Bear guts are cleaned and dried. Little pieces are eaten to cure indigestion.
} 
concise. In most cases the children return home with new supernatural power.

A man brings home food from a feast; his eldest son eats it; the father scolds the boy; the boy stays in bed three days; he leaves and gets to salmon country where he marries the chief's daughter (Nass ARBAE $31: 886$ ).

A hungry boy (two brothers) takes some of his father's salmon roe; his father beats him; a stranger urges him to eat all the salmon; he is beaten again; he prays on the beach and (helped by Moon Man) obtains much herring for his father (who becomes a wealthy chief) (Kwakiutl MAM 14:375; Yookilta IS 131; Nootka IS $115)$.

A boy eats some of the eggs he was sent to gather; his father strikes him; he leaves; he learns to fly and obtains a dance (Kwakiutl IS 162).

Children eat up their mothers' mussels; the children are beaten; they leave and become a new tribe (Nootka IS 119).

A prince gives his hungry slave boy a piece of dried salmon which his mother is saving; the prince is scolded by his mother; he leaves and is taken to Salmon country (Tsimshian ARBAE $31: 193$ ).

A woman scolds her husband for giving her step-son too much to eat; the boy leaves; he returns after two years with the power to obtain all sorts of fish (Bella Coola IS 266).

A father invites strangers to eat tallow; his daughters have already been fed the tallow by their grandmother (two girls eat between meals); the girls' mother scratches their cheeks; the two girls leave and marry Mountain Dweller; they return home with huge quantities of food (Tlingit BBAE $39: 222,280$ ).

\section{The Practical Joker}

Man on visit to friend learns he is out fishing

Man pretends to be fish and friend fishes him up

Friend much frightened

Two men were friends. Just before they parted one said to the other, "When I die you can take my gun." "Good," answered his friend. Then the second got to thinking about having the gun and came to the conclusion, "I may as well get the gun. He gave it to me anyway just as if it were mine."

He went to his friend's house and inquired of his wife, "Where is my friend ?" "He's gone. He went to the river to fish." "I'll go after him." 
He went to the river and saw his friend fishing. He was so engrossed he did not see his friend as he approached, so the latter decided to play a trick. He undressed and went into the water. The shore was steep where the man was fishing. His friend dived and swam under the water. The current was swift and when the fisherman threw in his line it went far downstream. The friend went up to it and took hold of it. The fisherman pulled and thought he had a bite. He pulled and saw he was fishing up a person. He was so frightened he did not know what he was doing but kept pulling, meantime walking backwards.

The catch came ashore and followed the line. The fisherman was so frightened he did not recognize his friend, nor did he stop pulling. Finally the friend said, "What's the matter with you? Don't you know what you're doing?"

Then his friend recognized him and they had a big laugh.

A similar joke is played in a tale of the Comox:

Two young men come upon their grandfather in heaven fishing; they turn into salmon which their grandfather harpoons; they resume their true form and laugh at their joke before stating their actual errand (IS 66).

In Thompson myths the Transformers play the trick in fish disguise on Cannibal:

Cannibal is out spearing fish; one of the Transformer brothers pretends to be a fish; Cannibal spears him; the Transformer swims away with Cannibal's spearhead; Cannibal sulks; the Transformers return the spearhead to Cannibal's delight; he feeds them much food in little (MAM 12:221, 315; MAFLS 6:43).

In a Haida story the assumption of the fish disguise is used in a display of supernatural power, rather than in a practical joke.

A chief's son enters his silver salmon skin and steals Master Hopper's spear point; he returns the spear point (BBAE 29:267 and cp. this work tale 1).

\section{War between the Blackfoot and the Coeur d'Alene}

Coeur d'Alene hunt buffalo in Blackfoot country

Recognized by a Blackfoot, party turns back

Chief tells story of his youth

Blackfoot had stolen Coeur d'Alene horse

Coeur d'Alene located horse as it was drinking at river

Blackfoot scalped and sent home 
The people went travelling to hunt buffalo. Some white people had settled near the Blackfoot. The Coeur d'Alene put up for the night near that settlement. One of them was recognized by one of the Blackfoot. So he said, "Let us go back." The next morning the chief called the people together.

"When I was a boy all the horses were stolen. I was just about the size of Ben (He Who Gathers Bones). ${ }^{1}$ I looked for my favorite horse. He was gone. The chief called, 'We'll track them.' Some who went said, 'We'll find it for you.' The party became separated. Four went one way, the rest another. Two of the Coeur d'Alene and two Salish (from Where River Widens) saw the Blackfoot coming. There were six of them. They chased the Blackfoot into the river. One of the horses was thirsty and would not move even when he was kicked. The Blackfoot did all he could to start him but the horse drank slowly. The Blackfoot jumped into the water which came to his armpits. The Coeur d'Alene chased the Blackfoot. The horses got tired. When the Coeur d'Alene came near, the Blackfoot aimed his arrow. A Coeur d'Alene went up to him and aimed his gun. The Blackfoot put his hands before his face to defend himself. The other took pity on him and came very near. "Why don't you shoot him?' another Coeur d'Alene asked. They closed in upon him and cut off his long hair. Each one took a braid with a part of the scalp. The blood flowed. He cried. Tears ran down his cheeks. $\mathrm{He}$ was told, 'Go you may live. We will not kill you.',

That is the end.

'The informant's name for Ben Nicodemus who was thirteen at the time. 


\section{BIBLIOGRAPHY AND ABBREVIATIONS}

In the bibliography the abbreviations have been made to conform as closely as possible with those used by G. P. Murdock in his Ethnographic Bibliography of North America. As a matter of convenience MAMNH has been shortened to MAM. There are two lists, one of authors and titles, the other of abbreviations so that the references may be easily found.

\section{Authors ANd Titles}

Adamson, Thelma. Folk-Tales of the Coast Salish. Memoirs of the American FolkLore Society (MAFLS) 27 (1934).

Andrade, M. J. Quileute Texts. Columbia University Contributions to Anthropology (CUCA) 12 (1931).

Ballard, A. C. Mythology of Southern Puget Sound. University of Washington Publications in Anthropology (UWPA) 3(1929):31-150.

Ballard, A. C. Some Tales of the Southern Puget Sound Salish. UWPA 2(1927): 57-81.

Boas, F. Chinook Texts. Bulletin Bureau of American Ethnology (BBAE) 20 (1894).

Boas, F. Einige Sagen der Kootenay. Verhandlungen der Berliner Gesellschaft für Anthropologie, Ethnologie und Urgeschichte (VBGA) 23 (1891) :161-2.

Boas, F. Indianische Sagen von der Nord-Pacifischen Küste Amerikas. (IS) 1895.

Boas, F. Kathlamet Texts. BBAE 26 (1901).

Boas, F. Kwakiutl Culture as Reflected in Mythology. MAFLS 28 (1935).

Boas, F. The Kwakiutl of Vancouver Island. Memoirs American Museum of Natural History (MAM) 8(1909) :307-515.

Boas, F. Kwakiutl Tales. CUCA 2 (1910).

Boas, F. Kwakiutl Tales, new series. CUCA 26 (1935).

Boas, F. The Mythology of the Bella Coola Indians. MAM 2(1900) :25-127.

Boas, F. Race, Language and Culture. New York. 1940.

Boas, F. Traditions of the Ts'ets'aut. Journal of American Folk-Lore (JAFL) 9 (1896):257-68; 10(1897) :35-48.

Boas, F. Tsimshian Mythology. Annual Report Bureau of American Ethnology (ARBAE) 31 (1916).

Boas, F. Tsimshian Texts. BBAE 27 (1902).

Boas, F. Tsimshian Texts (New Series). Publications American Ethnological Society (PAES) 3 (1912).

Boas, F. and Chamberlain, A. Kutenai Tales. BBAE 59 (1918).

Boas, F. and Hunt, G. Kwakiutl Texts. MAM 5(1905) :1-532. Kwakiutl Texts, Second Series. MAM 14(1906):1-269.

Chapman, J. W. Ten'a Texts and Tales from Anvik. PAES 6 (1914).

Dixon, R. B. Achomawi and Atsugewi Tales. JAFL 21 (1908) :159-77.

Dorsey, G. A. The Pawnee: Mythology. Carnegie Institution of Washington (CI) (1906).

Dyer, C. L. Mythology of the Kutenai. Unpublished manuscript.

Farrand, L. Traditions of the Chilcotin Indians. MAM 4(1900):1-54. 
Farrand, L. and Kahnweiler, W. S. Traditions of the Quinault Indians. MAM 4(1902): 77-132.

Frachtenberg, L. See St. Clair.

Golder, F. A. Tlingit Myths. JAFL 20(1907):290-5.

Hill-Tout, C. Notes on the N'tlakápamuq Indians. Report of the First Meeting of the British Association for the Advancement of Science (BAAS) 69(1899): 500-85.

Hill-Tout, C. Notes on the Sk'qo'mic of British Columbia. BAAS 70 (1900) :472-549.

Hill-Tout, C. Report on the Ethnology of the Okana'ken. Journal of the (Royal) Anthropological Institute of Great Britain and Ireland (JAI) 41(1911): 130-61.

Hill-Tout, C. Report on the Ethnology of the Si'ciatl of British Columbia. JAI 34(1904) :20-91.

Hill-Tout, C. Report on the Stsee'lis and Sk'au'lits Tribes of the Halkome'lem Division of the Salish of British Columbia. JAI 34 (1904) :311-376.

Hunt, G. See Boas and Hunt.

Jacobs, M. Northwest Sahaptin Texts. UWPA 2(1929) :175-244.

Jacobs, M. Northwest Sahaptin Texts. CUCA 19 (1934).

Jones, W. Ojibwa Texts. PAES 7 (1919).

Lowie, R. H. The Assiniboine. Anthropological Papers American Museum of Natural History (APAM) 4 (1910).

Phillips, E. M. Columbia River Tales. The Idaho Farmer. August 7, 14 ; September $18,1930$.

Phinney, A. Nez Percé Texts. CUCA 25 (1934).

Ray, V. F. Sanpoil Folk Tales. JAFL 46(1933):129-87.

Reichard, G. A. Coeur d'Alene. Handbook of American Indian Languages (HAIL) $3(1938): 515-707$.

Reichard, G. A. Imagery in an Indian Vocabulary. American Speech 18(1943) : 96-102.

Sapir, E. Takelma Texts. University of Pennsylvania Museum Anthropological Publications (UPMAP) 2 (1909).

Sapir, E. Wishram Texts. PAES 2(1909).

Spinden, H. J. Myths of the Nez Percé Indians. JAFL 21 (1908) :13-23, 149-58.

Spinden, H. J. See Teit and Others.

St. Clair, H. H. and Frachtenberg, L. J. Traditions of the Coos Indians. JAFL 22(1909) :25-41.

Swanton, J. R. Contributions to the Ethnology of the Haida. MAM 8(1909):1-300.

Swanton, J. R. Haida Texts, Masset Dialect. MAM 14(1908) :273-812.

Swanton, J. R. Haida Texts and Myths, Skidegate Dialect. BBAE 29(1905).

Swanton, J. R. Tlingit Myths and Texts. BBAE 39 (1909).

Taverner, P. A. Birds of Western Canada. Victoria Memorial Museum Bulletin 41 (1926), Ottawa.

Teit, J. A. The Lillooet Indians. MAM 4(1906):193-300.

Teit, J. A. Mythology of the Thompson Indians. MAM 12(1912) :199-416.

Teit, J. A. The Salishan Tribes of the Western Plateaus. ARBAE 45(1930) :447758.

Teit, J. A. The Shuswap. MAM 4 (1906): 447-758.

Teit, J. A. The Thompson Indians of British Columbia. MAM 2(1900):163-392.

Teit, J. A. Traditions of the Lillooet Indians of British Columbia. JAFL 25(1912) : 287-371. 
Teit, J. A. Traditions of the Thompson River Indians of British Columbia. MAFLS 6 (1898).

Teit, J. A. and Others. Folk-Tales of Salishan and Sahaptin Tribes. MAFLS 11 (1917).

Waterman, T. T. The Explanatory Element in the Folk-Tales of North American Indians. JAFL 27 (1914) :1-54.

\section{Abbreviations}

APAM 4, see Lowie.

ARBAE 31, see Boas, Tsimshian Mythology

ARBAE 45, see Teit, The Salishan Tribes

BAAS 69, see Hill-Tout, Notes on the N'tlakápamuq

BAAS 70, see Hill-Tout, Notes on the Skqo'mic

BBAE 20, see Boas, Chinook Texts

BBAE 26, see Boas, Kathlamet Texts

BBAE 27, see Boas, Tsimshian Texts

BBAE 29, see Swanton, Haida Texts and Myths, Skidegate Dialect

BBAE 39, see Swanton, Tlingit Myths and Texts

BBAE 59, see Boas and Chamberlain

CI, see Dorsey

CUCA 2, see Boas, Kwakiutl Tales

CUCA 12, see Andrade

CUCA 25, see Phinney

CUCA 26, see Boas, Kwakiutl Tales, New Series

HAIL, see Reichard, Coeur d'Alene

Idaho Farmer, see Phillips

IS, see Boas, Indianische Sagen

JAFL 9, see Boas, Traditions of the Ts'ets'aut

JAFL 20, see Golder

JAFL $21: 13-23$, 149-58, see Spinden

JAFL $21: 159-77$, see Dixon

JAFL 22, see St. Clair

JAFL 25, see Teit, Traditions of the Lillooet

JAFL 27, see Waterman

JAFL 46, see Ray

JAI 34, see Hill-Tout, Report on the Ethnology of the Si'ciatl, and Report on the Stsee'lis

JAI 41, see Hill-Tout, Report on the Ethnology of the Okana'k'en

MAFLS 6, see Teit, Traditions of the Thompson

MAFLS 11, see Teit and Others

MAFLS 27, see Adamson

MAFLS 28, see Boas, Kwakiutl Culture as Reflected in Mythology MAM $2: 25-127$, see Boas, The Mythology of the Bella Coola Indians MAM 2:163-392, see Teit, The Thompson Indians of British Columbia MAM 4:1-54, see Farrand, Traditions of the Chilcotin

MAM $4: 77-132$, see Farrand and Kahnweiler

MAM $4: 193-300$, see Teit, The Lillooet Indians

MAM $4: 447-758$, see Teit, The Shuswap 
MAM $5: 1-532$, see Boas and Hunt

MAM 8:1-300, see Swanton, Contributions to the Ethnology of the Haida MAM 8:307-515, see Boas, The Kwakiutl of Vancouver Island MAM $12: 199-416$, see Teit, Mythology of the Thompson Indians MAM 14:1-269, see Boas and Hunt

MAM $14: 273-812$, see Swanton, Haida Texts, Masset Dialect

PAES 2, see Sapir, Wishram Texts

PAES 3, see Boas, Tsimshian Texts (New Series)

PAES 6, see Chapman

PAES 7, see Jones

RLC, see Boas, Race, Language and Culture

UPMAP, see Sapir, Takelma Texts

UWPA 2:57-81, see Ballard, Some Tales

UWPA $2: 175-244$, see Jacobs

UWPA 3, see Ballard, Mythology of Southern Puget Sound

VBGA 23, see Boas, Einige Sagen 


\section{MEMOIRS OF THE AMERICAN FOLKLORE SOCIETY}

*Volume out of print or out of stock

Vol. *1. Folk Tales of Angola, by Heli Chatelain. With Ki-mbundu text. 1894. 315 pp.

*2. Louisiana Folk Tales, by Alcee Fortier. In French dialect and English translation. 1895. 122 pp.

*3. Bahama Songs and Stories, by Charles L. Edwards. With music. 1895. 111 pp.

*4. Current Superstitions, from the Oral Tradition of English-speaking Folk, by Fanny D. Bergen. 1896. 161 pp.

*5. Navaho Legends, by Washington Matthews. With texts and melodies. Illustrated. 1897. $299 \mathrm{pp}$.

6. Traditions of the Thompson River Indians of British Columbia, by James Teit. With introduction by Franz Boas. 1898. 137 pp. $\$ 3.50$.

7. Animal and Plant Lore, by Fanny D. Bergen. 1899. 180 pp. $\$ 3.50$.

8. Traditions of the Skidi Pawnee, by George A. Dorsey. 1904. 366 pp. $\$ 6.00$.

9. Los Pastores. A Mexican Miracle Play, by M. R. Cole. 1907. 234 pp. $\$ 4.00$.

10. Spanish American Folk Songs, by Eleanor Hague. 1917. 111 pp. $\$ 3.50$.

11. Folk Tales of Salishan and Sahaptin Tribes, by J. A. Teit, M. K. Gould, L. Farrand, and H. J. Spinden. 1917. 201 pp. \$3.50.

12. Filipino Popular Tales, by Dean S. Fansler. 1921. 473 pp. $\$ 5.00$.

13. The Folk Tales of Andros Island, Bahamas, by Elsie Clews Parsons. 1918. 170 pp. $\$ 3.50$.

*14. Index to the Journal of American Folk-Lore. 1930. \$5.50 net.

15. Folklore from the Cape Verde Islands, by Elsie Clews Parsons. 1923. 640 pp. 2 vols. $\$ 7.00$.

16. Folk Tales of the Sea Islands, South Carolina, by Elsie Clews Parsons. 1923. 218 pp. $\$ 3.50$.

*17. Jamaica Anansi Stories, by Martha Warren Beckwith. 1924. 295 pp. $\$ 3.50$.

*18. Folk-Lore of Maryland, by A. W. Whitney and C. C. Bullock. 1927.238 pp.

19. Tewa Tales, by Elsie Clews Parsons. 1927. 304 pp. $\$ 3.50$.

*20. Lamba Tales, by C. M. Doke. 1927.570 pp.

21. Jamaican Folklore, collected by Martha Warren Beckwith, with music recorded in the field by Helen $H$. Roberts. Illustrated. 1929.347 pp. $\$ 5.00$.

*22. Kiowa Tales, by Elsie Clews Parsons. 1929. 152 pp.

*23. Folk-Lore from the Dominican Republic, by Manuel J. Andrade. 1931. 432 pp.

*24. Folklore from Nova Scotia, by Arthur Huff Fauset. 1931. 204 pp. $\$ 3.50$.

*25. Bella Bella Tales, by Franz Boas. 1932.178 pp. $\$ 3.50$.

26. Folklore of the Antilles, French and English, by Elsie Clews Parsons. Part I. 1933. 521 pp. \$5.00. Part II. 1936. 569 pp. \$5.00. Part III. 1943. 487 pp. $\$ 4.00$.

*27. Folk-Tales of the Coast Salish, by Thelma Adamson, 1943. 430 pp.

*28. Kwakiutl Culture as Reflected in Mythology, by Frank Boas. 1935. 190 pp.

*28. Folklore from Iowa, by Earl J. Stout. 1936. 228 pp. $\$ 3.50$. 
*30. Spanish Folk-Tales from New Mexico, by José Manuel Espinosa. 1937. 222 pp. $\$ 3.50$.

*31. Myths and Tales of the Jicarilla Apache Indians, by Morris Edward Opler. 1938. 406 pp. $\$ 3.50$.

32. Mandan-Hidatsa Myths and Ceremonies, by Martha W. Beckwith. 1938. 327 pp. $\$ 3.50$.

*33. Myths and Tales of the White Mountain Apache, by Grenville Goodwin. 1939. 223 pp. $\$ 3.50$.

34. Taos Tales, by Elsie Clews Parsons. 1940. 188 pp. $\$ 3.50$.

35. Tales from Jalisco, Mexico, by H. T. Wheeler. 1944. 562 pp. $\$ 4.00$.

36. Myths and Legends of the Lipan Apache Indians, by Morris Edward Opler. 1940. 296 pp. $\$ 3.50$.

37. Myths and Tales of the Chiricahua Apache Indians, by Morris Edward Opler, with an Appendix of Apache and Navaho Comparative References by David French. 114 pp. 1942. $\$ 2.50$.

38. Japanese Peasant Songs, by John F. Embree. 105 pp., pls. 1943. \$3.00.

39. Hill Country Tunes of Pennsylvania, by Samuel P. Bayard. 1944. 110 pp., music. $\$ 3.00$.

40. Myths of the Toba and Pilagá Indians of the Gran Chaco, by Alfred Métraux. 1946. 167 pp. $\$ 3.00$.

41. An Analysis of Coeur d'Alene Indian Myths, by Gladys A. Reichard. 1947. ? ? pp. $\$ 4.00$.

The above volumes are for sale by the American Folklore Society at reduced prices to members. Volumes 1 and 5 may be procured as reprints from G. E. Stechert \& Co., New York. 



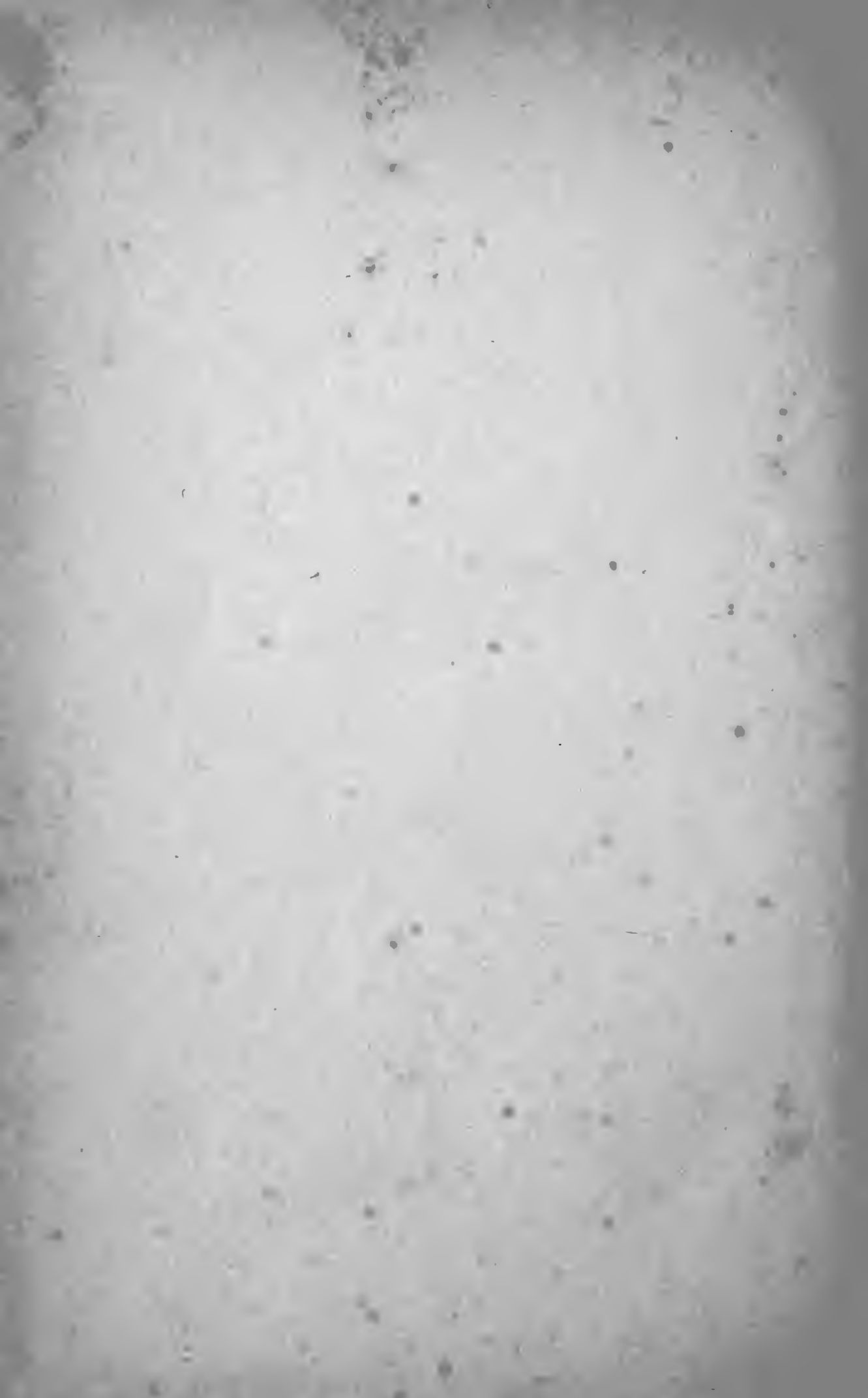


Withdrawn trom UF. Surveyed io internet Archive

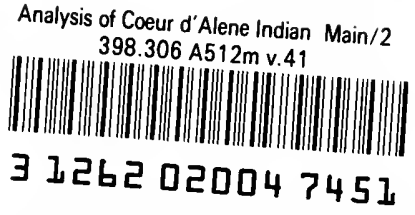




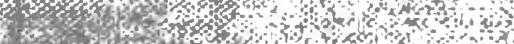

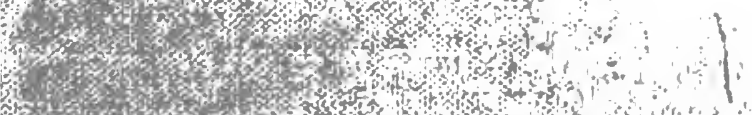

SW

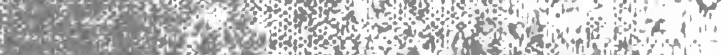

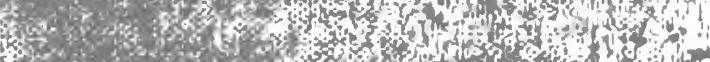

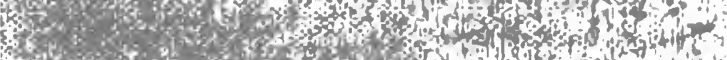

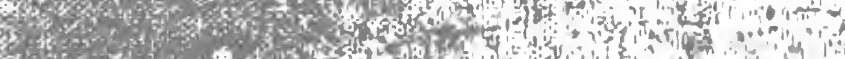

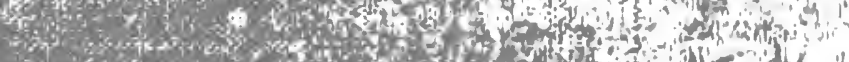
20.

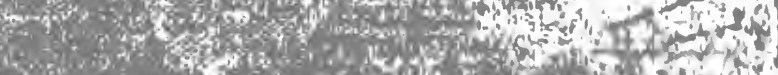

igat

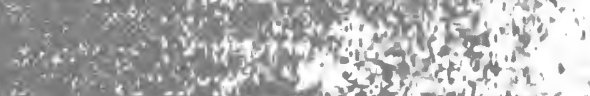
ase

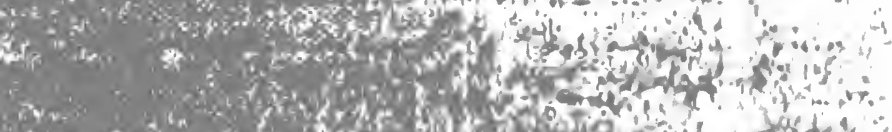

